\title{
Inequality, Identity, and the Structure of Political Cleavages in South Korea, Taiwan, and Hong Kong, 1996-2016
}

Carmen Durrer de la Sota

Amory Gethin

February 2021

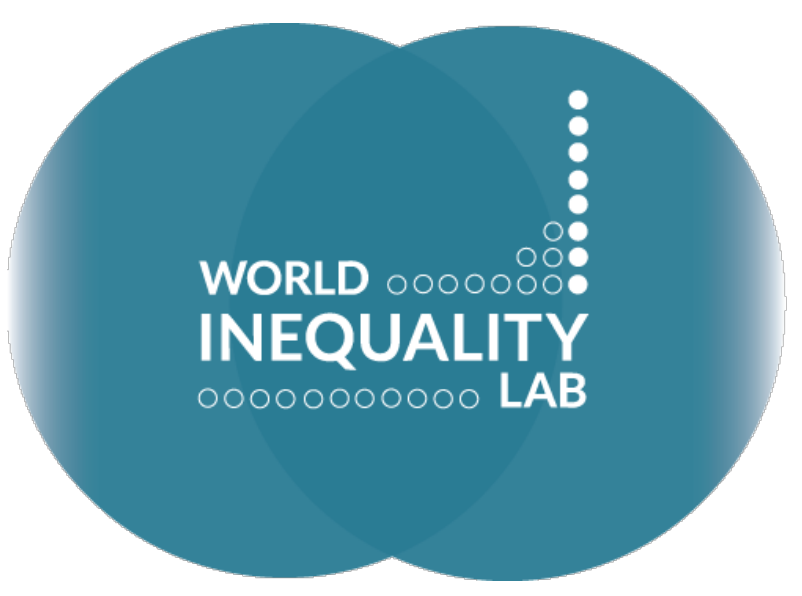

WID.WORLD

THE SOURCE FOR

GLOBAL INEQUALITY DATA 


\title{
Inequality, Identity, and the Structure of Political Cleavages in South Korea, Taiwan, and Hong Kong, 1996-2016*
}

\author{
Carmen Durrer de la Sota \\ Amory Gethin ${ }^{\dagger}$
}

\begin{abstract}
This paper documents how democratization in South Korea, Taiwan, and Hong Kong since the 1980s has led to the materialization of growing political cleavages. Political integration, manifested by attitudes towards North Korea in South Korea, and towards mainland China in Hong Kong and Taiwan, have been a key issue structuring party competition and electoral behaviors in the three territories. In Hong Kong and South Korea, this issue has sharply divided old and new generations, albeit in a somewhat different way. In Hong Kong, younger cohorts are substantially more likely to vote for parties supporting lower political integration. In South Korea, older generations show significantly higher support for unification, but they are also much more likely to vote for conservatives, who firmly oppose any attempt to engage with the North Korean regime, a phenomenon rooted in decades of tensions and fiercely anticommunist regimes. In Taiwan, such a strong generational divide is absent, but the independence/unification cleavage has interacted with ethnicity: immigrants from mainland China and their descendants have been more supportive of the pro-unification Kuomintang than natives. This is also the case in Hong Kong, where sustained immigration from the mainland has come with the emergence of a strong anti-immigration cleavage. We argue that the strength of these cleavages and the lack of political mobilization of the working class for historical reasons have played a key role in explaining the near absence of class cleavages in all three territories. While economic concerns do play a role in nurturing mass mobilizations, cultural and political identities, rather than material concerns, seem to continue shaping party systems in East Asia.
\end{abstract}

\footnotetext{
${ }^{*}$ We are grateful to Joel Campbell, Eui-Young Jung, Karl Ho, Wai-Man Lam, Clara Martínez-Toledano, Sidney Michelini, Thomas Piketty, and Sebastian Veg for their useful advices. We also thank the team of the Comparative Study of Electoral Systems and of the Hong Kong Election Study for making the datasets used in this paper available for research.
}

${ }^{\dagger}$ Carmen Durrer de la Sota, Amory Gethin: Paris School of Economics - World Inequality Lab. 


\section{Introduction}

South Korea, Hong Kong, and Taiwan have witnessed dramatic political transformations since the 1980s, including institutional reforms and the conduct of elections on a regular basis. In South Korea, the presidential elections of 1987 announced the advent of democracy after almost three decades of military rule. In Taiwan, direct legislative elections in 1992 allowed opposition forces to run against the ruling Kuomintang for the first time. In Hong Kong, democratization has been more tortuous, with semi-direct elections being held in 1991 by the British and pursued by the Chinese government since the handover of 1997.

In all three territories, the past three decades have been associated with a greater participation of the population to the making of the polity. This growing mobilization has, at the intersection of historical legacies and contingent factors, triggered the institutionalization of political parties and the formation of clear partisan divides. In Taiwan and Hong Kong, parties organized into two camps: those opposing greater integration with mainland China, and those in favor of it. With the rise of the pro-independence Democratic Progressive Party, Taiwan transitioned to a two-party system in the mid-2000s. The division between the pro-democracy camp and the proBeijing camp in Hong Kong goes back further in time, and the pro-democracy camp has received a stable 60 percent of popular votes since 1991. While democratic reform, economic issues, and cultural concerns have interacted with this dimension of political conflict, relations to the mainland have remained omnipresent in the political sphere. In South Korea, party system institutionalization has been more complex. As minor conservative parties and independents gradually lost in importance in the 1990s, the liberal Democratic Party grew as the main opposition force to the conservative coalition inherited from the dictatorship. However, party institutionalization remains incomplete. Political parties are still strongly dependent on their leadership and their name and structure experience frequent changes. Foreign policy has also remained at the heart of political conflicts in South Korea, as the institutionalization of the conservative-liberal opposition materialized diverging attitudes towards North Korea, although 
unlike in Taiwan or Hong Kong, the conflict does not concern whether or not to seek unification, but how to interact with the northern regime in the meantime.

Alongside political transitions, South Korea, Taiwan, and Hong Kong also experienced deep economic transformations. After several decades of sustained economic development, East Asian economies were hit hard by the Asian Financial Crisis of 1997, and have been unable to go back to the exceptional rates of growth they had achieved between the 1960s and the mid1990s. ${ }^{1}$ Income inequality has risen significantly, driven by a conjunction of changes on the labor market, soaring housing prices in big cities, and the failure of governments to implement policies protecting those most vulnerable to economic shocks. ${ }^{2}$

These transformations have arguably affected existing boundaries of political mobilization, created new demands, and generated new divides. In this paper, we use existing political attitudes surveys conducted in South Korea, Taiwan, and Hong Kong since the late 1990s to document how structures of political cleavages in these three territories have responded to these different political, economic, and cultural concerns. Our results bring us to two main findings.

First, we document that relations to the "other", whether mainland China in Hong Kong and Taiwan or North Korea in South Korea, have remained at the heart of politics, trumping other dimensions of social conflict, and shaping political cleavages. "National" or "local" identity feelings have risen in all three territories over the past decades, in particular among younger cohorts. In South Korea, in addition to pre-existing regional divides, electoral behaviors have been tightly linked to age and education, as older, lower-educated voters display a greater

\footnotetext{
${ }^{1}$ Between 1970 and 1980, for instance, the average national incomes per adult of South Korea, Taiwan, and Hong Kong grew at cumulated rates of 67 percent, 74 percent, and 54 percent respectively. Between the 2000 and 2010 , the corresponding figures were 51 percent, 58 percent, and 19 percent. Authors' computations based on figures from the World Inequality Database. See World Inequality Database, “Average National Income”, WID.world, https://wid.world/world\#anninc_p0p100_z/HK;TW;KR (accessed June 15, 2020).

${ }^{2}$ On South Korea, see the longer discussion in the next section. On Taiwan, see for instance Chu (2015). On Hong Kong, see the discussion below, as well as Hung (2018).
} 
rejection towards engagement with the North Korean regime despite their stronger hopes for unification. In Taiwan, identity has interacted with ethnicity, as mainlanders - immigrants coming from the mainland at the end of the Chinese civil war and their descendants - continue to display stronger attachment to China and to the hope of eventual unification. In Hong Kong, it is again age and education which are the strongest predictors of vote choice, as mounting polarization between pro-democrats and pro-Beijing forces have driven increasing student mobilization.

Secondly, while economic concerns do matter significantly in fostering mass mobilizations, we find only limited evidence of independent class cleavages in these three territories. In Hong Kong, for instance, rising housing prices and decreasing perceived social mobility have been important factors in the student protests against the Chinese regime. In Taiwan, fears that greater trade integration would worsen regional inequalities may have also contributed to reinforce preexisting North-South divides. In South Korea, promises of action against rising economic polarization have become omnipresent in political campaigns, and income may be starting to play a role in influencing vote choices. Yet, we find economic inequality to be poorly represented in the East Asian party systems studied in this paper.

This underrepresentation, we argue, is partly the result of the fact that the integration/separation cleavage is almost completely orthogonal to social class. In South Korea, a large share of the poor are elderly citizens, who favor a hard stance against North Korea and are consequently more supportive of conservative parties. In Taiwan, ethnicity is only weakly correlated to income; unlike South Africa and Malaysia, where opposition to the former ethnic elite still has a strong class dimension, the mainlander-native divide is one of historical identities rather than conflicting economic interests. In Hong Kong, low-income voters are more supportive of the pro-Beijing camp, but this is mainly because they tend to be older and are more likely to be immigrants from Mainland China. All these factors suggest that the political representation of economic inequalities in these three territories remains in large part framed, and sometimes hindered, by divides over relations to the "other". Given mainland China's growing economic power and renewed expansionist attitude, as well as the growing threat of North Korean 
nuclearization, these divides are likely to persist and to play an increasing role in both domestic and foreign politics.

\section{South Korea}

Contemporary South Korean politics have been inevitably shaped by the country's unique history and intricate position in the international scene. A product of the Cold War, South Korea's borders were set through the arbitrary partition of the Korean peninsula by the United States and the Soviet Union at the end of World War II. The division of the Korean nation and the hostility of the North Korean regime have been defining features of South Korea's history and political system ever since. In the words of Hieyeon Keum and Joel Campbell, "The NorthSouth Korean issue became the background concern of all other major political issues, powerfully informed the formation of political parties, and stood behind the nature of political cleavages and the types of corruption experienced" (Keum and Campbell 2018). The North Korean security threat was used by the authoritarian regimes of the 1960s-1990s as a source of legitimacy and a justification for political oppression (Freedman 2006; Kil and Moon 2001). The military dictatorships also left behind a long-lasting regional cleavage, as both the stateled economic development and the violent repression of anti-regime demonstrations had a strong territorial component.

In this section, we show that South Korean political cleavages are changing quite significantly. While regionalism persists, its importance has substantially decreased since democratization. A rising generational cleavage, as in Hong Kong, has determined much of the vote in recent elections, driven by diverging attitudes towards North Korea but also by the elderly poverty crisis. In addition, the economic polarization suffered since the 1997 crisis has brought redistributive issues to the center of the political discourse, and a modest class cleavage may be emerging, with low-income voters showing less support for the conservatives than the middle class, but only after accounting for age composition effects. University graduates have in parallel decreased their support for the conservatives, producing a unique configuration of the low-income and the higher educated simultaneously favoring progressive parties. 
Before the partition, the Korean peninsula had continuously been a single political entity since 936. After falling under Japanese domination in 1905, it officially became a Japanese colony in 1910. In the wake of the surrender of Japan in 1945, the US and the Soviet Union divided the peninsula into two occupation zones along the 38th parallel. In 1950, the attempt by North Korea to unify the peninsula under communist rule triggered the start of the Korean War, which reached a stalemate in 1953, after immense human and material losses, consolidating the division of the peninsula.

It was only two years earlier, in 1948, that the two Koreas had materialized into separate states. In the south, nationalist leader Syngman Rhee instigated the founding of the Republic of Korea, just shortly before the establishment of its Soviet backed northern counterpart. A series of strongly anti-communist, US-backed, authoritarian regimes ensued until 1987. ${ }^{3}$ After 15 years of repressive rule, President Rhee was ousted by a pro-democratic revolution in 1960. Only one year later, a coup led by General Park Chung-hee placed the country under a military dictatorship. Through the developmental state model and with the financial and political support of the US, Park-Chung Hee led the country through a period of rapid economic growth. Income per capita in South Korea went from \$100 in 1960 to \$13,000 in 1996, an unprecedented phenomenon in the country's history. The regime promoted industrialization and export-led growth, leading to the emergence of a crucial nucleus of power in South Korean politics, the Chaebol, or big business conglomerates. Park Chung-Hee, who had tightened his grip on power in 1972 and was facing increasing social unrest, was assassinated in 1979 by one of his closest confidents at the head of the South Korean secret service. Chun Doo-hwan, in charge of the investigation of Park's murder took over the regime. By the late 1980s, rising public protest and international pressures facilitated the opening of the South Korean regime, which

\footnotetext{
${ }^{3}$ With the exception of a short period of parliamentarism between the 1960 April revolution and the military coup in May.
} 
culminated in 1987 with the first free presidential election in 26 years, and the election of the first opposition president, democratic activist Kim Dae-Jung, in 1997 (Freedman 2006; Hellman 2011; Keum and Campbell 2018).

South Korea's democracy has been shaped by the country's experience of bureaucratic authoritarianism and its Confucian heritage, leading to the development of a strongly personalistic, so-called "imperial presidency" (Hellmann 2011; Kil and Moon 2001). As a consequence, party institutionalization has been rather weak, with major parties often changing their names under each new leader (Freedman 2006). However, despite the nominal changes, two underlying coalitions can be distinguished across elections. The conservative coalition descends directly from the authoritarian regimes. The progressive coalition, on the other hand, grew out of the democratic opposition. ${ }^{4}$ As shown in Figure 1, South Korea has progressively evolved into a two-party system, even though smaller parties have remained significant, receiving 10 to 20 percent of votes in most elections. ${ }^{5}$

\footnotetext{
${ }^{4}$ A non-exhaustive list of names used by the conservative party is: Democratic Justice Party, Democratic Liberal Party, Hannara Pary, Saenuri Party, Liberty Korea Party, and United Future. A non-exhaustive list of names used by the progressive party is: Democratic Party, Millennium Democratic Party, Democratic United Party, and Uri Party.

${ }^{5}$ The results discussed in this section correspond to the vote by constituency, which allocates 253 of the 300 seats in parliament. The results of the vote for the proportional party lists are less concentrated around the two main parties but do not change the general findings.
} 
Figure 1 - Legislative election results in South Korea by coalition, 1985-2020

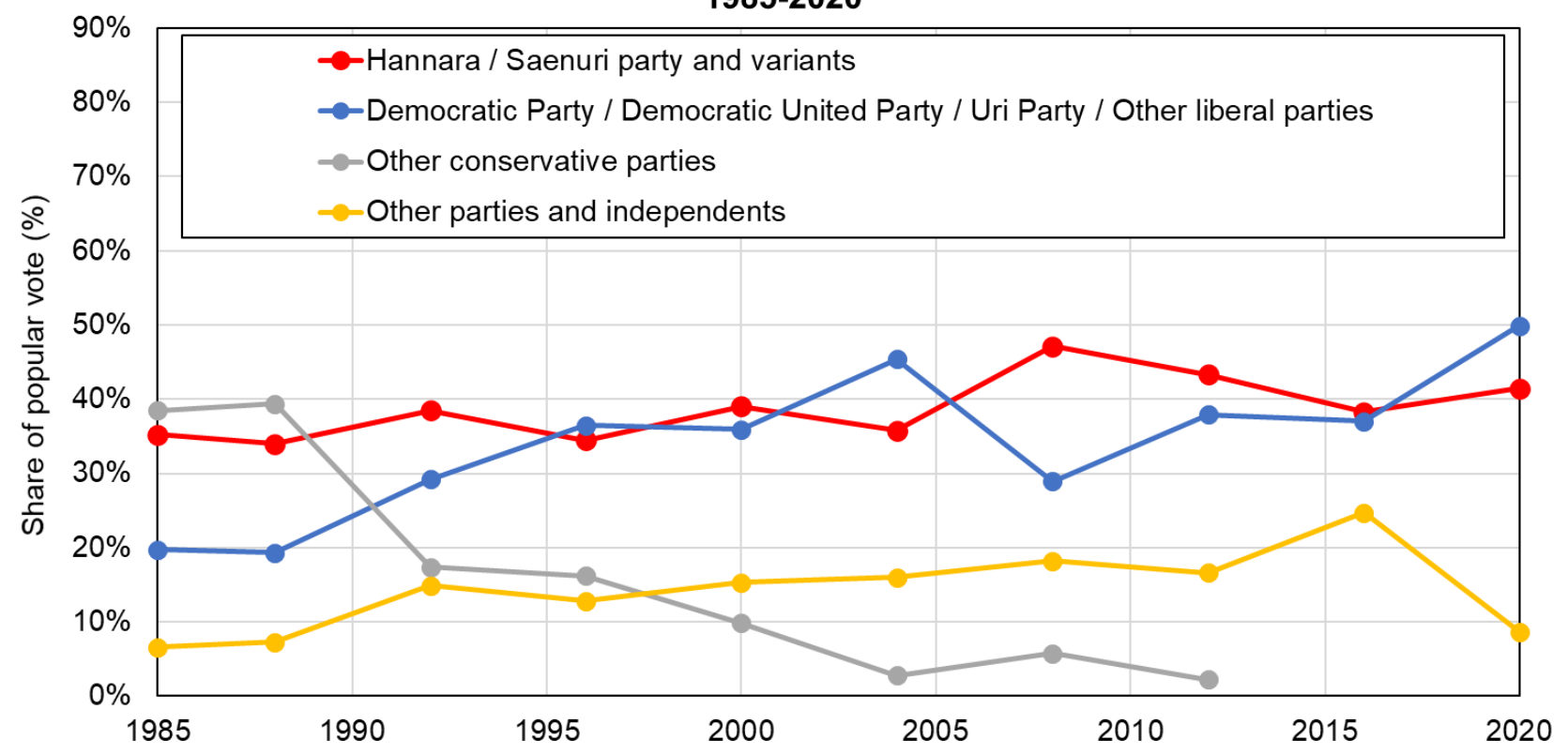

Source: authors' computations using official election results.

Note: the figure shows the share of votes received by selected groups of South Korean political parties in legislative elections between 1985 and 2020. Variants to the Hannara party include the United Future are Hannara, Saenuri, Democratic Justice, Democratic Liberal, New Korea, and Liberty Korea.

Another major challenge facing South Korean democracy is endemic corruption, which is often linked to the enormous grip of the Chaebols on the country's economy and politics as well as the importance of clientelist networks in the electoral process. Six out of seven presidents since the democratic transition (all but the sitting president Moon Jae-in) have either been convicted of corruption or been part of a corruption scandal involving family members. The South Korean democracy is therefore characterized as a "flawed democracy" in the Economist Intelligence Unit Democracy Index (2019). However, despite its challenges, democracy is still supported by a large majority of the South Korean population, a hopeful sign for its consolidation (Denyer and Kim 2018; Keum and Campbell 2018).

\section{Social Inequalities in South Korea}

The extraordinary economic development experienced by South Korea between the 1960s and the 1997 Asian Financial Crisis was internationally praised as an example of "growth with 
equity" (Stiglitz and Pleskovic 1998). However, in the aftermath of the 1997 Asian Financial Crisis, South Korea's balanced growth came to an end and inequality rose substantially, driven by neoliberal economic reforms and the high concentration of the market under the Chaebols. Between 1995 and 2016, the income share of the top 10 percent rose substantially, from 32 percent to 43 percent, and that of the top 1 percent from 7 percent to 12 percent. ${ }^{6}$ Studies have emphasized the role played by the neoliberal economic reforms undertaken after the 1997 crisis and during the 2000s, particularly labor market flexibilization, the high concentration of the South Korean market under the Chaebols, and the increase in concentration of wealth as the main culprits of the widening income gaps (Y. Kim 2018).

The rapid rise in inequality over the past two decades has disproportionately affected the older generation. The share of the elderly among the bottom quintile has grown significantly, leaving them more exposed to the already large, widening gap between income groups. South Korea's poverty rate among those over 65 has reached an alarming 44 percent in 2019, the highest among OECD countries, compared to an average of 17 percent for the general population. ${ }^{7}$ This dramatic deterioration in the living standards of the elderly has been linked to several cultural, demographic and economic factors. Like other Asian countries, South Korea used to rely on younger family members to provide care for the elderly. The gradual distancing of the youth from traditional values coupled with the ageing of the population has left many elderly reliant on an underdeveloped public pension system, where the basic benefits were only 6 percent of the average wage in 2015 (OECD 2015).

\footnotetext{
${ }^{6}$ Other inequality measures such as the 80:20 ratio and the Gini coefficient also increased sharply after the crisis. See N. N. Kim (2018).

${ }^{7}$ Poverty rates are measured by the OECD as the fraction of a given group of the population whose income is below 50 percent of the median national household income. See OECD, "Poverty rates", OECD.org, https://data.oecd.org/inequality/poverty-rate.htm (accessed on June 15, 2020). In 2016, the elderly made over 40 percent of the poorest quintile, even though they only represented 20 percent of the population. See appendix Figures A8, A17 and A18.
} 
Over the same period, the average educational level has soared. The South Korean youth (aged 25 to 34) in particular, have almost doubled their share of tertiary graduates, from 37 percent in 2000 to 70 percent in 2018, the highest in the OECD. ${ }^{8}$ However, differences in average educational level across age groups have actually narrowed slightly ${ }^{9}$, and the distribution of educational attainment across income groups has barely changed in relative terms. This suggests that broad changes in education cannot explain the rapid increase in inequality. Regional inequalities have also somewhat increased over the past two decades, with the SeoulGyeonggi region representing an increasing share of higher income groups and the historically wealthy Gyeongsang region a larger fraction of the poor. ${ }^{10}$ However, these changes pale in the light of the growing age gap.

Rising inequalities have been a major cause of recent changes in the political discourse in South Korea, bringing more attention to redistributive issues and further popularizing the development of the welfare state. The high level of economic disparities in the country have been accused of weakening the young democracy, leading to the generalization of the motto "democratize the economy" in recent political campaigns, highlighting the discontent with the Chaebols' concentration of economic and political power (Im 2018). ${ }^{11}$ Already in 2009, the International Social Survey Programme found that 90 percent of Koreans perceived income

\footnotetext{
8 See OECD, "Population with tertiary education", OECD.org, https://data.oecd.org/eduatt/population-withtertiary-education.htm (accessed on June 15, 2020).

${ }^{9}$ Average educational attainment is measured here simply by codifying primary, secondary and tertiary education as a categorical variable and looking at the changes in averages by age group between 2000 and 2016.

${ }^{10}$ For example, Seoul's inhabitants represented 57 percent of the $5^{\text {th }}$ quintile in 2000 , and $59 \%$ percent in 2016 . In the same period, their share among the bottom 20 percent has decreased dramatically from 35 percent to 23 percent. The Gyeongsang region has experienced the reverse tendency, representing 25 percent of the bottom quintile in 2000 and over 41 percent in 2016. Given that the age structure of regions has not changed significantly over the same period, the increase in regional inequalities cannot be explained through a generational composition effect. For these numbers, see appendix Figures A11 to A20.

${ }^{11}$ The expression has been widely used across the South Korean political spectrum, most notably by Park Geunhye (conservative) in her 2012 presidential campaign and by Moon Jae-in (Democrat) in his 2012 and 2017 presidential bids.
} 
inequalities as too large, and some 75 percent believed it is the government's responsibility to tackle the issue (Kang 2017). Even former President Park Geun-hye, a conservative, centered much of her 2012 campaign on social policies, showing that changes have taken place across the political aisle. In 2017, Democratic candidate Moon Jae-in won the presidential election after running a campaign full of promises to expand the state's redistributive efforts and tackle the excessive power of the Chaebols. While foreign policy and corruption still receive much of the attention, economic inequalities are becoming an increasingly relevant topic in the political arena (Yang 2017; Kim 2010). ${ }^{12}$

\section{The North Korea Cleavage}

The Korean peninsula had been unified for over a thousand years at the time of its division in 1945, albeit under foreign influence on numerous occasions. Koreans shared a common language, culture, and history as well as a strong national identity. It is therefore not surprising that diplomatic relations with North Korea and the question of unification have remained at the forefront of Korean politics until the present day. In fact, Yoonkyung Lee and Jong-sung You show that an individual's self-reported position on a progressive-conservative scale is much more strongly linked to their attitude towards North Korea than to their opinions on inequality, redistribution, earned income, or self-perceived class belonging (Lee and You 2019). A similar salience of the foreign policy debate is found in Taiwan and Hong-Kong with respect to China, highlighting the centrality of international relations in a region where international trade is key and strong tensions persist. In South Korea, however, negative attitudes towards North Korea are closely related to conservative political positions (Lee and You 2019), contrary to the ideological divide found in Taiwan and Hong-Kong (see below). ${ }^{13}$

\footnotetext{
${ }^{12}$ Economic polarization is also attracting more attention in popular culture. The recent success of the film Parasite, which portrays the gap between the urban poor and the wealthy in South Korea, hints at a change in social attitudes towards equity issues.

${ }^{13}$ Negative attitudes are measured by Lee and You (2019) as agreeing with the statement "We should be wary of or hostile toward North Korea".
} 
The hard stance on North Korea of the pre-democratic authoritarian regimes was inherited by the Grand National Party and its successors (now the United Future at the time of writing), while the Democratic Party historically advocated for a more pragmatic policy of engagement. President Kim Dae-Jung's "Sunshine Policy" of the early 2000s was the concrete articulation of the Democratic vision (Koh 2001). It promoted cultural and economic exchanges with North Korea, with the final goal of reaching de-facto unification, in which people, goods and services could freely move across the border. The policy marked a before and after in modern interKorean relations, but also increased the polarization of South Korea's domestic debate on the North Korean issue, with conservatives accusing Kim Dae-Jung of giving in to the demands of the North Korean regime without achieving any reciprocity, and even betraying the North Korean people by providing aid to the totalitarian regime. The conservatives' return to power between 2007 and 2017, and in particular Lee Myung-bak's presidency (2007-2012) entailed a reversion to a more rigid approach to North Korean relations. In practice, most of the interKorean negotiations over the past decade have revolved around North Korea's nuclear program, in an attempt to promote the denuclearization of the peninsula. Since 2017, President Moon Jae-in's North Korean policy has marked a return to the spirit of the Sunshine policy, culminating in three inter-Korean summits during 2018 and 2019. However, progress on denuclearization has been rather limited so far (Pacheco Pardo 2018; Choe 2018).

The North Korean cleavage is primarily structured along generational lines. Elder voters tend to oppose the Democratic Party's engagement policy, yet survey data from the Asian Institute for Policy Studies show that they are also significantly more prone to support unification and have a stronger sense of North Korea being part of the same nation than their young counterparts. The South Korean youth, as in Hong Kong and Taiwan, seems to have begun to develop a sense of South Korean national identity, drifting away from their cultural and historical ties to the north. The increasingly frequent contact of the South Korean youth with the rest of the world has prompted awareness among them of their country's cultural and economic proximity with the West and its distance to modern day North Korea (Campbell 2011). In 2017, almost 50 percent of South Koreans in their twenties declared perceiving North 
Korea as a "Stranger/Enemy", and only 32 percent felt they were "One of [them]", compared to 29 percent and 62 percent respectively for those aged 60 and above (Jiyoon, Kim, and Chungku 2018). The youth's support for unification is also significantly lower, and when present it is much more likely to be due to security concerns rather than a feeling of national unity. Yet, support for unification remains very high among the general population and has increased between 2010 and 2017, with 82 percent of South Koreans favoring a unified Korea.

\section{The Intensification of Generational Divides}

Age has become an increasingly better predictor of voting behavior in recent years, with older people showing a much stronger support for the conservatives than younger generations (Hellmann 2011; Kim and Park 2018). As shown in Figure 2, in 2016 the elderly (those aged 60 or above) were 25 percentage points more likely to vote for the conservatives than their younger counterparts, versus 4 percentage points in $2000 .{ }^{14}$ We show in the appendix that after controlling for other socioeconomic variables, in particular for education, the gap is reduced to 16 percentage points in 2016 and the trend becomes less clear, but the divide remains significant. The large discrepancy between the pre- and post-controls numbers comes from a rising interaction between education and age, as tertiary graduates are increasingly less likely to vote for the conservative party, and the share of tertiary educated is much lower among the elderly. ${ }^{15}$

\footnotetext{
${ }^{14}$ The trend is stable except in 2008, where age does not seem to play as much of a role in voting behavior. There are several potential reasons explaining the break, as the 2008 elections were rather exceptional, with a very low participation rate (46.1 percent, the lowest since democratization) and a significant division of the conservatives into three parties. Disappointment with the exiting Rho Moo-hyun's progressive administration was quite strong, and the Democratic Party obtained a particularly bad result amid high abstention of the youth. On the other hand, the conservative vote was split across three parties, with Park Geun-hye's coalition performing particularly well among the elderly, leaving a more age-balanced electoral base to the GNP. The break in the trend may, however, also be due to reduced accuracy of the data through the high abstention rate.
}

${ }^{15}$ See appendix Figures A23 and A24. 
Figure 2 - Vote for the Hannara / Saenuri Party by age group

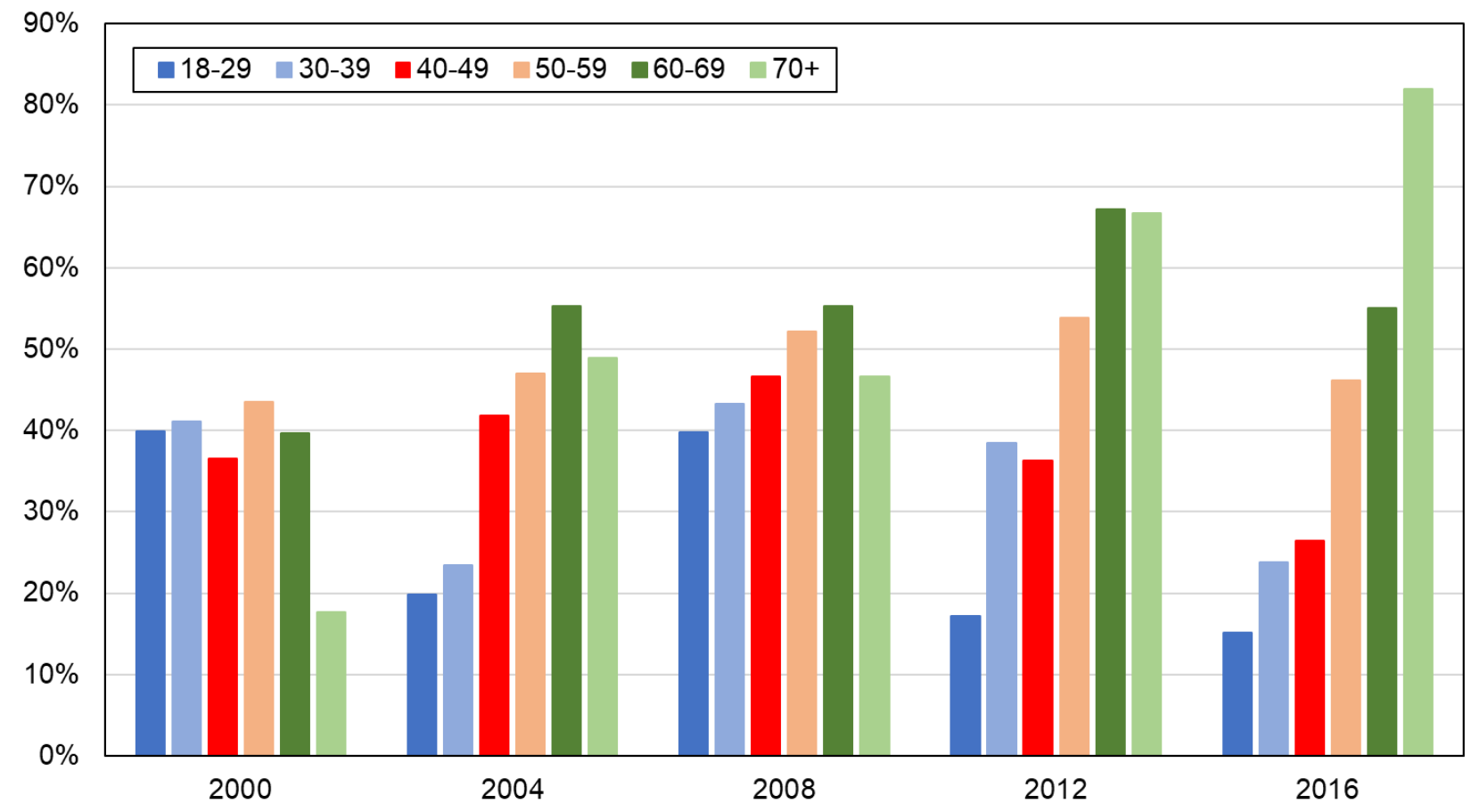

Source: authors' computations using South Korean political attitudes surveys.

Note: the figure shows the share of votes received by the Hannara / Saenuri Party by age group.

The first symptoms of South Korea's generational divide are often traced back to the election of Roh Moo-hyun (Democrat) in 2002, whose victory was largely due to a very strong mobilization of the youth (Kim, Choi, and Cho 2008). Nevertheless, the major role played by students in the democratic opposition during the authoritarian regimes suggests we could be witnessing a revival more than an emergence of a generational cleavage. On the other hand, given the recent development of democracy in South Korea, it is important to note that the older generation grew up in a radically different political environment. Those aged over 60 in 2016 were young during the Park Chung-hee era, and as such witnessed South Korea's spectacular economic development firsthand. In contrast, over the past two decades of democratic rule the elderly have faced increasingly difficult material conditions. The conservatives may thus have benefitted from their historical ties to the Park regime in gaining the support of the older generation, a hypothesis that is backed by the fact that the generational gap appeared to widen in 2012, when Park's daughter, Park Geun-hye, was the conservative leader. Furthermore, the 
omnipresence of references to the North Korean threat in the political discourse during the decades authoritarian rule seems likely to have fed the rejection of the Democrats' engagement approach among older voters.

\section{The Decline of the Regional Cleavage}

Regional divides have famously been particularly strong in South Korea. The most salient divide, between the southwestern region of Honam and the southeastern region of Gyeongsang, dates to the pre-democratic era. Park Chung-hee's native Gyeongsang province was systematically privileged in economic and political matters under his rule. Meanwhile, the Honam region, a stronghold of the democratic opposition since the early years of authoritarian rule, was marginalized (Freedman 2006). In line with the existing literature, we find that the divide has persisted after South Korea's democratization, but it has significantly decreased. In 2000, voters from the Gyeongsang region were 74 percentage points more likely to vote for the Saenuri Party, after controlling for other socioeconomic factors. In 2016, the difference remained, but had fallen to 50 percentage points. The decrease, despite a bounce-back in 2008 , starts in 2004 and is often linked to the electoral reforms introduced by the Kim Dae-Jung administration and the nomination of Roh Moo-hyun, a Gyeongsang native, as the new Democratic leader in 2002. Notice that the regional cleavages are barely affected by the introduction of control variables, which shows that residual regional identities, rather than their social structure, explains regional divides in South Korea entirely. 
Figure 3 - The regional cleavage in South Korea

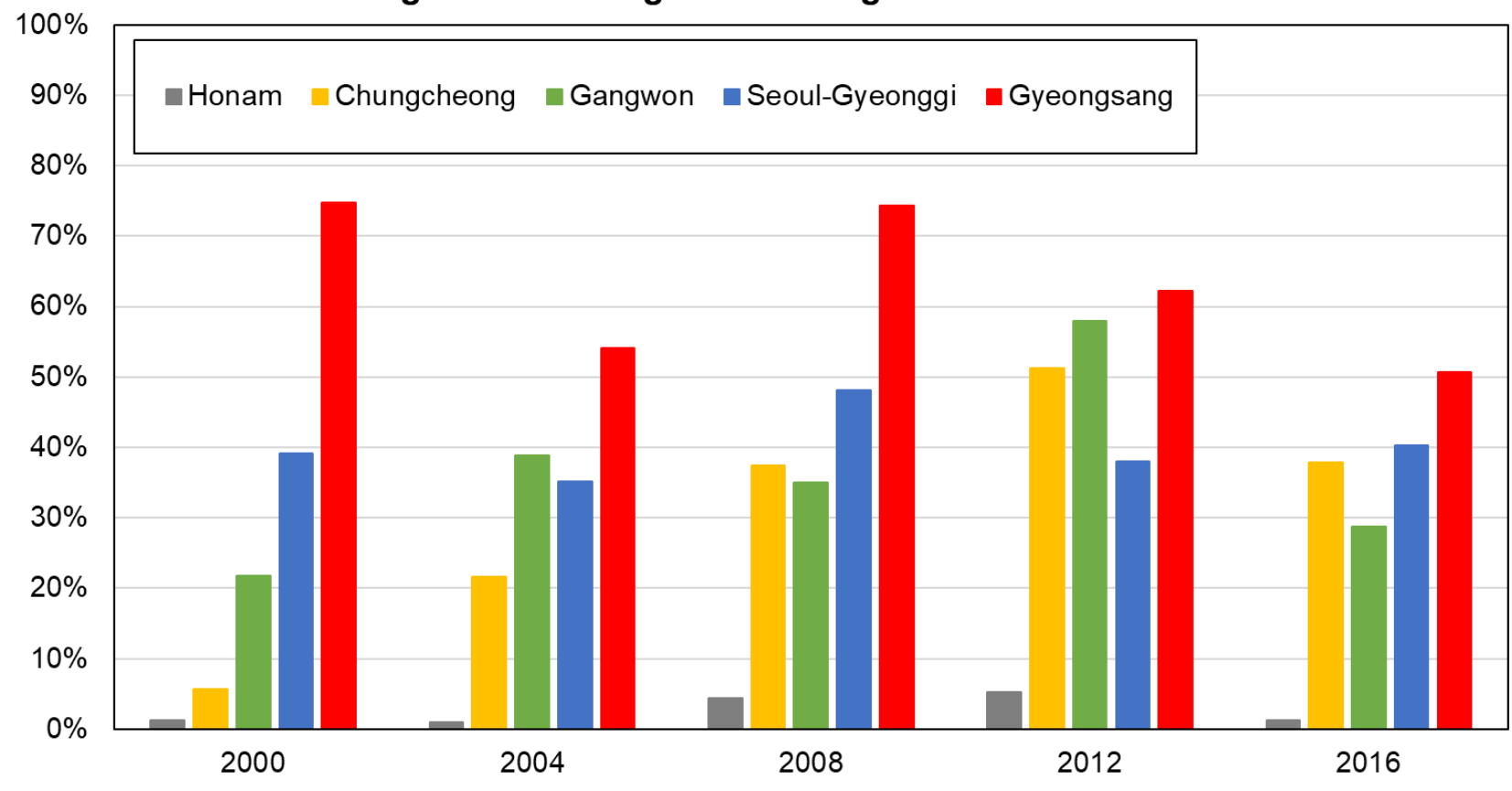

Source: authors' computations using South Korean political attitudes surveys.

Note: the figure shows the share of votes received by the Hannara / Saenuri Party by region. In 2016

Honam represented approximately $10 \%$ the elctorate, Chungcheong $10 \%$, Gangwon 4\%, Seoul-Gyeonggy $49 \%$, and Gyeongsang $26 \%$.

During the first years of democracy, regionalism expanded beyond the Honam and Gyeongsang divide. The "era of the three Kims" in the 1990s was marked by strong regional voting, with each candidate gathering large majorities in his home region. ${ }^{16}$ However, while regional voting has persisted in Honam and Gyeongsang, our data suggest that regionalism has all but disappeared in the rest of the country. ${ }^{17}$

${ }^{16}$ The “Three Kims” were Kim Jong-pil, from the Chungcheong province, Kim Young-sam from Gyeongsang and Kim Dae-jung from Honam. All three gathered between 60 percent and 90 percent of the vote in their native region in the 1992 elections.

${ }^{17}$ See region coefficients after controls in Table A3 in the appendix. 
Class cleavages in South Korean politics have been rarely discussed, as the consensus used to be that they were absent from the country's political system. Regional voting and ideology (often through the North Korean cleavage) were so strong that hardly any other voting factor was observed. The absence of class voting was also rather unsurprising, as South Korea's relatively low level of inequality during the first decade of democracy and the repression of labor movements during the authoritarian regimes meant the very drivers of class cleavages were absent (Hellmann 2011). However, in recent years, economic polarization and the increased salience of redistributive issues in the political debate have reopened the question of class voting. One of the problems with analyzing class voting in South Korea, as noted by Yoonkyung Lee and Jong-sung You, is the very strong overlap between age and income (Lee and You 2019). The strong conservatism and the high rates of poverty among the elderly have caused much of the literature to talk about "reverse-class voting" (Kang 2017).

Indeed, if we look at voting results across income groups, the support of the poor for conservatives is quite salient. ${ }^{18}$ However, we find that once age is controlled for, or once voters older than 60 are removed from the sample, conservative vote is slightly higher among the middle 40 percent (the fifth to ninth deciles of income) than among the bottom 50 percent income earners (see Figure 4). Top income earners (top 10 percent) however, do not show a clear voting pattern. conservative vote becomes very slightly lower among the bottom 50 percent income earners compared to the middle 40 percent (Figure 4). While it may be too early to claim that class cleavages are emerging in South Korea given the short time-span and the relatively low magnitude of the phenomenon (the gap is of some 5 percentage points), a change

\footnotetext{
${ }^{18}$ See appendix Figure A28. The assimilation of class voting to income voting should not be problematic, as multiple studies show that income is by far the most important factor determining subjective class belonging in South Korea. See Lee and You (2019).
} 
seems to have been taking place, which suggests that income could be playing an increasing role in the future. ${ }^{19}$

Figure 4 - Vote for the Hannara / Saenuri Party among low-income voters

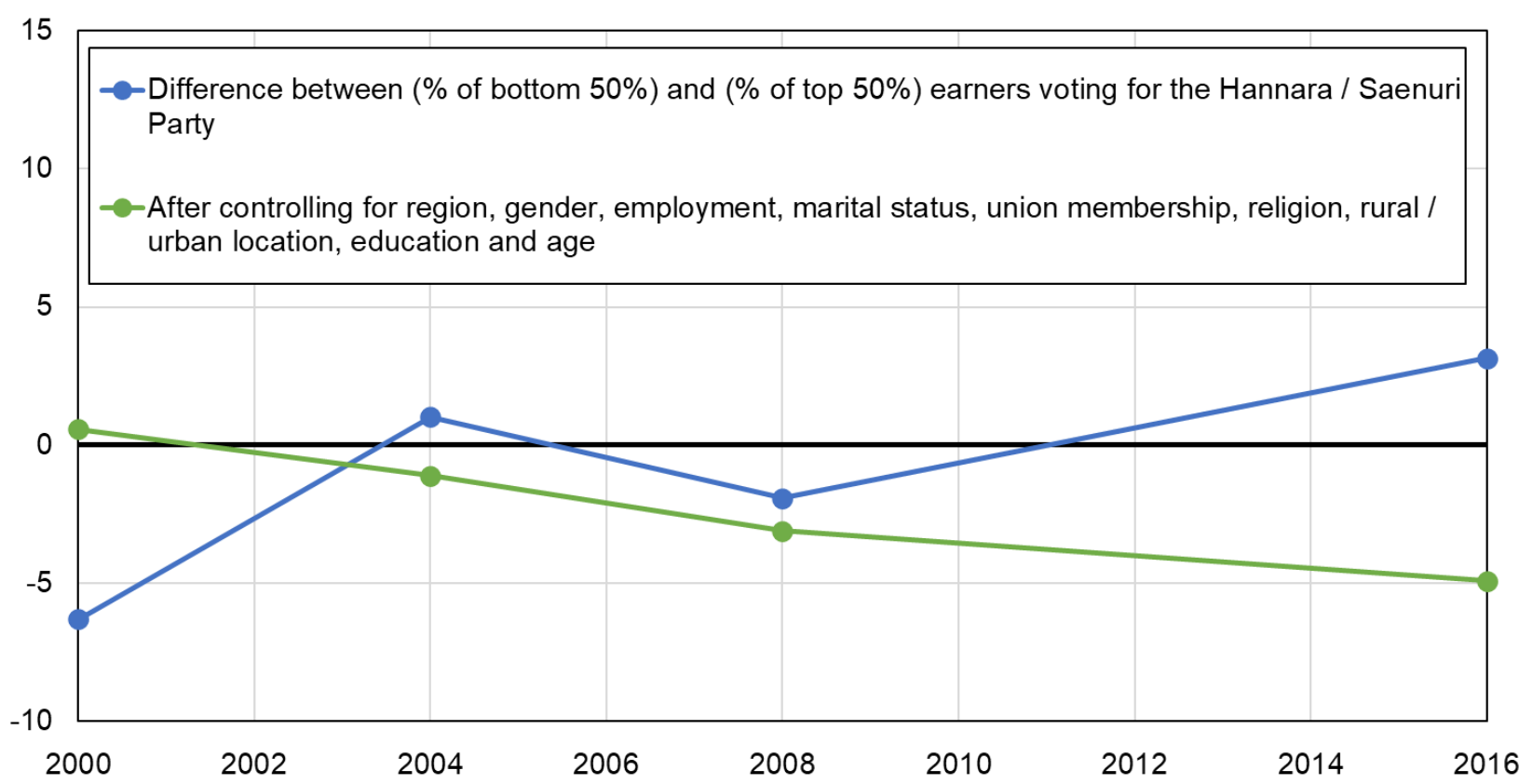

Source: authors' computations using South Korean political attitudes surveys.

Note: the figure shows the difference between the share of bottom $50 \%$ income voters and the share of top $50 \%$ income earners voting for the Hannara / Saenuri Party, before and after controlling for other variables.

It is worth noting that the trend in South Korea appears to be at odds with the recent experience of most Western democracies, where low-income voters' support for left-leaning parties has been eroding over the past decades (Gethin, Martínez-Toledano, and Piketty 2019). Moreover, the South Korean case is particularly interesting as low-income support for liberal parties has risen at the same time as that of tertiary graduates. Voters holding a university degree were indeed 7 percentage points less likely to vote conservative than their less educated counterparts in 2016, after controlling for other socioeconomic variables. In 2000, they were 7 percentage points more likely to vote for the Grand National Party (see Figure 5). South Korea therefore

\footnotetext{
${ }^{19}$ See, for example, Lee and You (2019), and Kim and Park (2018). Unfortunately, we do not have data on respondents' income for 2012.
} 
seems to be developing a unique set of political cleavages, in which university graduates vote with low-income voters. If this continues over time, it could mean the return of the studentsworkers coalition whose demonstrations greatly contributed to end the authoritarian rule and precipitated the advent of democracy.

Figure 5 - Vote for the Hannara / Saenuri Party among university

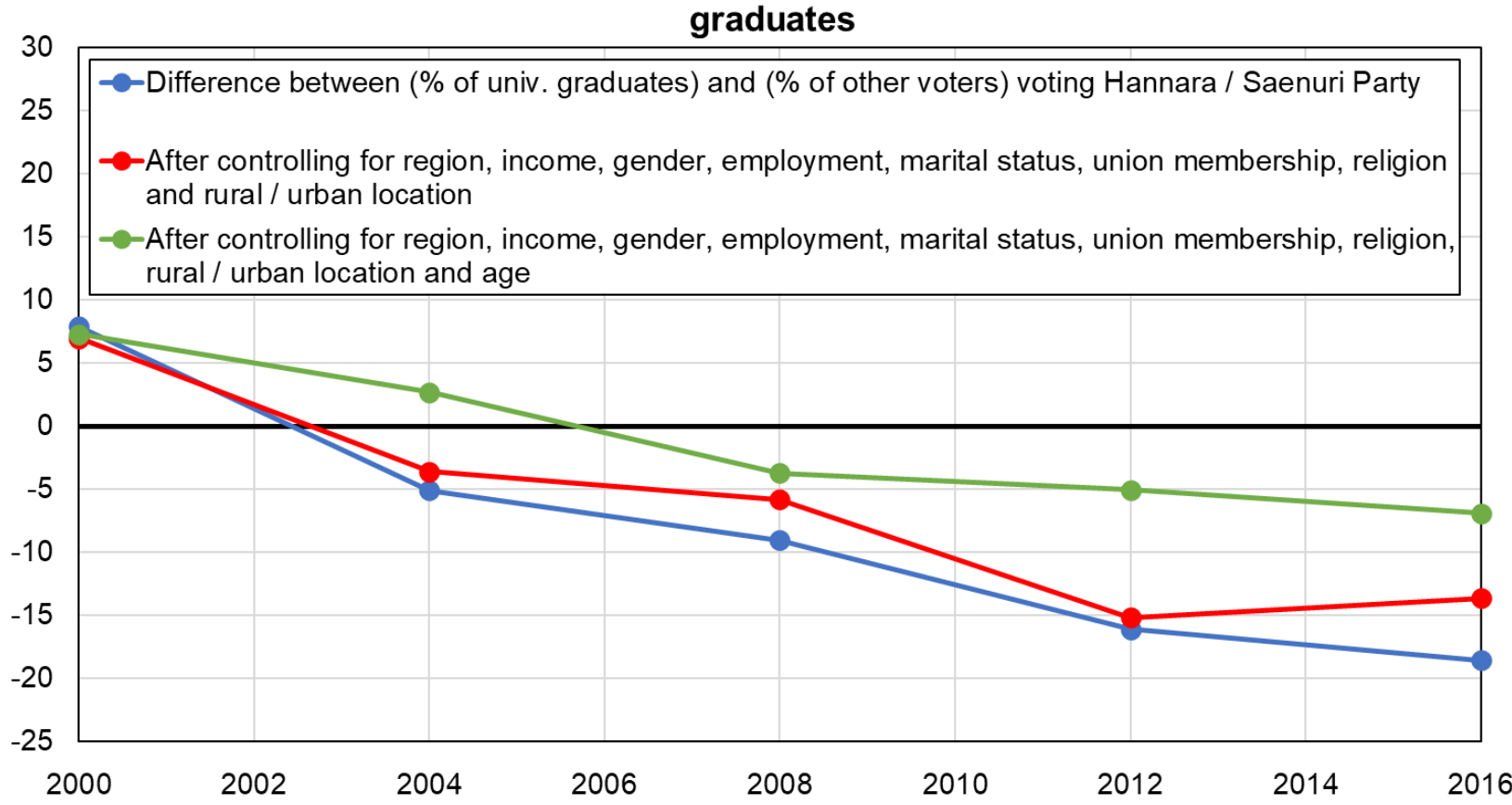

Source: authors' computations using South Korean political attitudes surveys.

Note: the figure shows the difference between the share of university graduates and the share of other voters voting for the Hannara / Saenuri Party, before and after controlling for other variables.

Overall, our results show that South Korean political cleavages are changing quite significantly. While regionalism persists in Honam and Gyeongsang, its importance has somewhat decreased, and regional voting has mostly disappeared in other parts of the country. Like in Hong Kong, a rising generational cleavage has determined much of the vote in recent elections. A growing age gap in the attitude towards North Korea and the elderly poverty crisis seem to have played a significant role carving the old-young divide. In addition, the economic polarization suffered by South Korea since the 1997 crisis has brought redistributive issues to the center of the political discourse, and a modest class cleavage may be emerging, with low-income voters showing less support for the conservatives than the middle class, but only after accounting for age composition effects. In parallel, however, university graduates have decreased their support 
for the conservatives, producing a unique configuration of the low-income and the highesteducated simultaneously favoring progressive parties. We will have to wait a few more elections to tell whether these long-run tendencies will persist or not.

\section{Taiwan}

As in South Korea and Hong Kong, contemporary Taiwanese politics have been structured by foreign policy. The island's political and cultural history is intrinsically linked to that of China. As synthesized by Achen and Wang (2017), this relationship has taken the form of a culture heritage, a security threat, and an economic opportunity. Immigration waves in the seventeenth century, along with the establishment of a local Chinese government by the Qing dynasty between 1684 and 1895, led Han Chinese to represent the majority of the island's inhabitants. Taiwan was ceded to Japan in 1895 , only to be given back to China at the end of World War II. The defeat of Chiang Kai-shek's Republic of China (ROC) against the Communist Party of China in the Chinese civil war came with the retreat of Chiang and two million of his followers to Taiwan in 1949. Taiwan and the mainland's common history, as well as the policies of Sinicization implemented by the Kuomintang (KMT) government in the second half of the twentieth century, contributed to foster a sense of Chinese identity, which has declined since democratization but does persist until today. ${ }^{20}$

Taiwan's relation to China has however been, both internally and externally, eminently conflictual. Internally, the corruption and repression of the Kuomintang government came with the formation of a social cleavage opposing mainlanders to the local residents speaking the Minnan and Hakka dialects. This cleavage culminated in the "2-28 Incident" of 1947, in which

\footnotetext{
${ }^{20}$ See in particular Wang (2017). Based on survey data, the author shows that in 1992, about 30 percent of respondents declared feeling only Chinese, 20 percent only Taiwanese, and 50 percent a dual identity. In 2012, these proportions had shifted to less than 5 percent, 55 percent, and 40 percent, so that single Taiwanese identification has become dominant.
} 
thousands of civilians were killed by the Republic of China's (ROC) troops. In the second half of the twentieth century, ethnic divisions in Taiwan lost much of their salience, but continued to frame citizens' opinions on the question of reunification with the mainland (Chu and Lin 2001). Externally, the communist People's Republic of China (PRC) never accepted to recognize the Taiwan-based government as the legitimate ruler of China, which led to repeated military incidents and diplomatic threats. The persistence of these tensions, along with the PRC's growing success at isolating Taiwan on the diplomatic scene, contributed to erode citizens' Chinese identity and their support for eventual reunification. As the democratization of the 1980s allowed the formation of the pro-independence Democratic Progressive Party (DPP), the present and future of relationships with the mainland became the new democracy's core political cleavage (Hsieh 2005).

Yet, the extraordinary growth of the Chinese economy in the past two decades has led to a remarkable intensification of economic exchanges between the two sides of the Taiwan Strait (Chiang and Gerbier 2013; Tan and Ho 2017). Policies implemented by both governments contributed to encourage this transformation, as revealed by the signature of the Economic Cooperation Framework Agreement (ECFA) in 2008 aiming to reduce tariffs and trade barriers in the two countries. While trade liberalization has often been embraced by both the KMT and DPP, it has opened a potential for a new division between the "winners" and the "losers" of globalization. This division could lead to a realignment of vulnerable workers towards the DPP, which is generally less favorable to strengthening relations with China, and eventually materialize in the form of a new class cleavage ( $\mathrm{Wu} 2013)$.

The study of electoral behaviors in Taiwan has been a flourishing field. A number of studies have documented the strength and persistence of the independence/reunification cleavage, and the role played by ethnic identities, partisan identifications, and the North-South divide in structuring its representation in electoral politics. ${ }^{21}$ While our findings are largely in line with the existing literature, our contribution is threefold. First, we aim to compare the

\footnotetext{
${ }^{21}$ An excellent review and synthesis of the field can be found in Achen and Wang (2017).
} 
independence/reunification cleavage in Taiwan to that observed in South Korea and Hong Kong: do we observe, for instance, generational and educational divides comparable to those found in these two countries? Secondly, we seek to understand better how the structure of political cleavages interacts with existing social inequalities: do ethnic and regional identities correlate to economic positions, or are these dimensions orthogonal to each other when compared to the other contemporary democracies? Third, we contribute to the existing debate on the potential for class cleavages in Taiwan by decomposing vote choices by income and education using indicators similar to those used for other countries studied in this paper, which allows meaningful international comparisons.

\section{Democratization and the Transformation of Taiwan's Party System}

When the Kuomintang government moved to Taiwan in 1949, it quickly established an authoritarian regime, prohibiting political parties, repressing dissident opinions, and controlling mass media. The KMT became the only legal political party, and the political representation of Minnans and Hakkas was suppressed. Local elections were implemented under the one-party regime, mainly as a way of recruiting political elites and distributing economic prerogatives, but they did permit independent candidates to run, which allowed non-KMT forces to gradually unify in the 1970s under the Tangwai movement (literally "outside the party"). At first a convenient label for differentiating KMP members from non-members, the Tangwai grew in the 1980s and became the strongest force pushing for the democratization of the political system (Yu 2017). The majority of independents eventually joined the new Democratic Progressive Party in 1986 and, after a gradual relaxation of existing legal constraints on the media and the political parties, the KMT government organized the first direct legislative election in 1992, and the first presidential election in 1996.

As shown in Figure 6, Taiwan has gradually stabilized into a two-party system as support for the DPP grew in the 1990s and 2000s. The share of votes received by the DPP grew from 21 percent in 1996 to 57 percent in 2020, and the party won the elections of 2000, 2004, 2016 and 2020, while a Kuomintang president was elected in 1996, 2008, and 2012. Other presidential 
Figure 6 - Presidential election results in Taiwan, 1996-2020

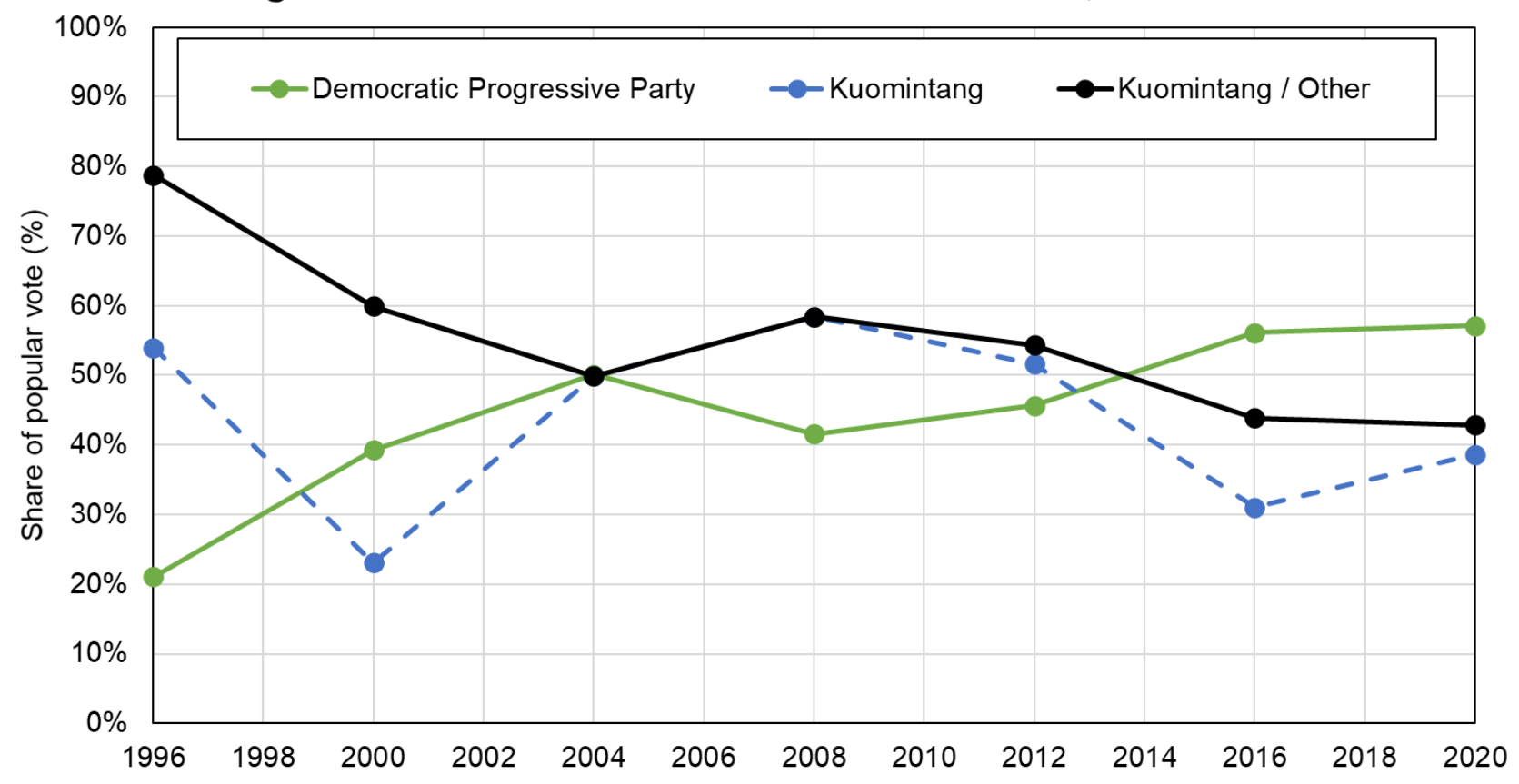

Source: authors' computations using official election results.

Note: the figure shows the share of votes received by selected groups of Taiwanese political parties in presidential elections between 1996 and 2020.

candidates since democratization have mostly consisted in KMT dissidents, and in particular former Taiwan governor James Soong, who chose to run as an independent candidate after failing to gain Kuomintang's nomination in 2000 and received 37 percent of votes. He has run in most presidential elections since then, but only captured 4.3 percent of votes in 2020 . Legislative elections have given greater space to small parties, such as the pro-unification New Party or the pro-independence Taiwan Solidarity Union, but the Legislative Yuan has also been divided into two main blocks, the KMT-led Pan-Blue Coalition and the DPP-led Pan-Green Coalition, with the majority of elected representatives joining one or the other of these coalitions. $^{22}$

\footnotetext{
${ }^{22}$ See appendix Figures B6 and B7 for election results in legislative elections. The New Party is a splinter party founded in 1993 by KMT members. The Taiwan Solidarity Union is a nationalist party which advocates for de jure independence of Taiwan.
} 
While the question of independence/unification has been the main issue in Taiwanese politics, there have been significant changes in the issues emphasized by political parties since democratization. In fact, before democratization was achieved, this cleavage was only one of several dimensions of political conflict with a potential to be represented in the emerging party system. In the 1980s, as the elites of the Dang-wai united to form an opposition group to the KMT, their main demand was not independence, but rather the reform of the political system (Hsieh 1996). ${ }^{23}$ It was only once the process of democratization was achieved that the DPP changed its focus to defending a strong position on independence of Taiwan from China (Sheng and Liao 2017).

One of the reasons for this strategic shift was that this question was deeply connected to latent divides between mainlanders and other ethnic groups, who had diverging beliefs and attitudes towards mainland China. By contrast, while income inequality had risen significantly in the 1980s, and government benefits had mostly accrued to mainlanders under KMT rules, democratization failed to trigger the emergence of a class cleavage, partly because the KMT strategically responded to redistributive claims, because Taiwan's economic structure, characterized by the multiplication of small businesses, made the mobilization of the working class particularly difficult and, as we will argue below, because ethnicity represented a very poor mediating factor for representing economic inequality. By framing the independence/unification issue, the DPP was able to attract the growing share of Minnan and Hakka citizens who felt more "Taiwanese" and less "Chinese". The DPP's stance on the process of independence itself has since then varied in being more or less radical, depending on the context and the party's electoral success, but it has remained the key feature distinguishing the KMT from the DPP in voters' minds (Sheng and Liao 2017).

\footnotetext{
${ }^{23}$ Based on a survey conducted in 1993, the article identified six issues on which parties competed: the economy, national identity, the environment, stability, local public works, and corruption. The author concluded that "the stability issue is the survival kit of the KMT."
} 
The existing literature has shown ethnicity to be a strong determinant of electoral behaviors and an enduring marker of attitudes towards independence or unification. Ethnolinguistic groups in Taiwan can be divided into four broad categories: Minnans, Hakkas, Mainlanders, and Aborigines. The Minnans and Hakkas refer to island residents whose ancestors migrated from China regions speaking the Minnan and Hakka dialects between the seventeenth and the first half of the twentieth century. In 2016, they represented about 72 percent and 14 percent of the Taiwanese electorate respectively. The Mainlanders amount to about 12 percent of the electorate and are the descendants of the approximately two million people who emigrated from China with Chiang Kai-shek at the end of the 1940s. The Aborigines, who represent less than 2 percent of the population today, are Austronesian indigenous people who lived on the island before the Han immigration waves of the seventeenth century - given too low sample sizes, we exclude them from our analysis. ${ }^{24}$

When the KMT imposed military rule and a one-party state on the island in the 1950s, it disproportionately favored the mainlanders, who were overrepresented in party membership and the civil service. Taiwan's social structure was therefore very comparable to that found in Malaysia (Gethin and Jenmana forthcoming) and South Africa (Gethin 2020), where an ethnic minority - mainlanders in Taiwan, the Chinese in Malaysia, and White colonizers in South Africa - controlled a large share of economic resources and of the state apparatus.

However, unlike in Malaysia and South Africa, where ethnic inequalities remained substantial throughout the twentieth century, the KMT initiated a large process of indigenization of state bureaucracy in the 1970s, after 20 years of Mainlander domination. ${ }^{25}$ This gradual incorporation

\footnotetext{
${ }^{24}$ See appendix Table B2 and Figure B11 for the composition of the Taiwanese electorate by ethnicity and its evolution over time.

${ }^{25}$ For example, the share of native Taiwanese in the civil services increased from 56.5 percent in 1959 to 71 percent in 1991. See Chu and Lin, "Political Development in 20 $0^{\text {th }}$ Century Taiwan”, 119.
} 
of Minnans and Hakkas into the state elite, as well as the economic boom of the 1970s and 1980s, the emergence of an export-led private sector, and growing intermarriage between mainlanders and native Taiwanese, together contributed to reduce ethnic inequalities and ethnic divides in Taiwan. ${ }^{26}$ Today, ethnicity and income are almost completely uncorrelated, and the share of lower-educated adults is only marginally lower among mainlanders than among native Taiwanese. ${ }^{27}$ In summary, while ethnic cleavages could be the precursor of class cleavages in ethnically structured economies like South Africa or Malaysia, this was not the case in Taiwan, where ethnolinguistic affiliations were almost entirely disconnected from social class.

\section{The Persistence of Ethnic Divides}

We now turn to the analysis of political cleavages in Taiwan by using post-electoral surveys conducted between 1996 and 2016, which asked respondents about their voting behaviors in presidential elections. ${ }^{28}$ Figures 7 and 8 show that the rise of the DPP since 1996 has coincided with the materialization of a strong ethnic cleavage. In 1996, the DPP was supported by only 2 percent of mainlanders compared to 18 percent of Hakkas and 25 percent of Minnans. Since

\footnotetext{
${ }^{26}$ In 2006, 42 percent of Taiwanese declared having a close relative married to a mainlander, and 67 percent declared getting along with Minnan, Hakka, and mainlanders about the same. See Wang (2017), 50.

27 See appendix Figures B17 and B18 for the composition of income quintiles by ethnolinguistic affiliation. According to the surveys at our disposal, mainlanders were slightly overrepresented in the upper middle-class in 1996, amounting to 11 percent of the first quintile compared to 16 percent of the fourth quintile, but these differences had almost completely vanished in 2016, even if mainlanders were slightly less represented among low-income groups. Jui-Chang Jao and Matthew McKeever (2006) documented that while older mainlanders were significantly more educated than Minnans and Hakkas in 1997, ethnic differences in educational attainments were almost insignificant among younger cohorts, and were almost entirely explained by parents' social background. Recent evidence from surname data suggests that the mainlander-native gap decreased monotonically between the 1950s and the 2000s, which show that export-led growth and democratization cannot be held sole responsible for these transitions: see Hao (2017).

${ }^{28}$ See appendix Table B2 for the full list of surveys used, which are taken from the website of the Comparative Study of Electoral Systems. The only exception is the 2001 survey, which only covers vote choice in the legislative elections.
} 
2001, less than 15 percent of mainlanders have voted for the DPP compared to more than 50 percent of Minnans. As shown in Figure 8, these extreme gaps have remained relatively stable since 1996, and they are highly robust to controlling for other sociodemographic variables, given that ethnicity is only weakly correlated to other sociodemographic characteristics.

Figure 7 - Vote for DPP by ethnicity

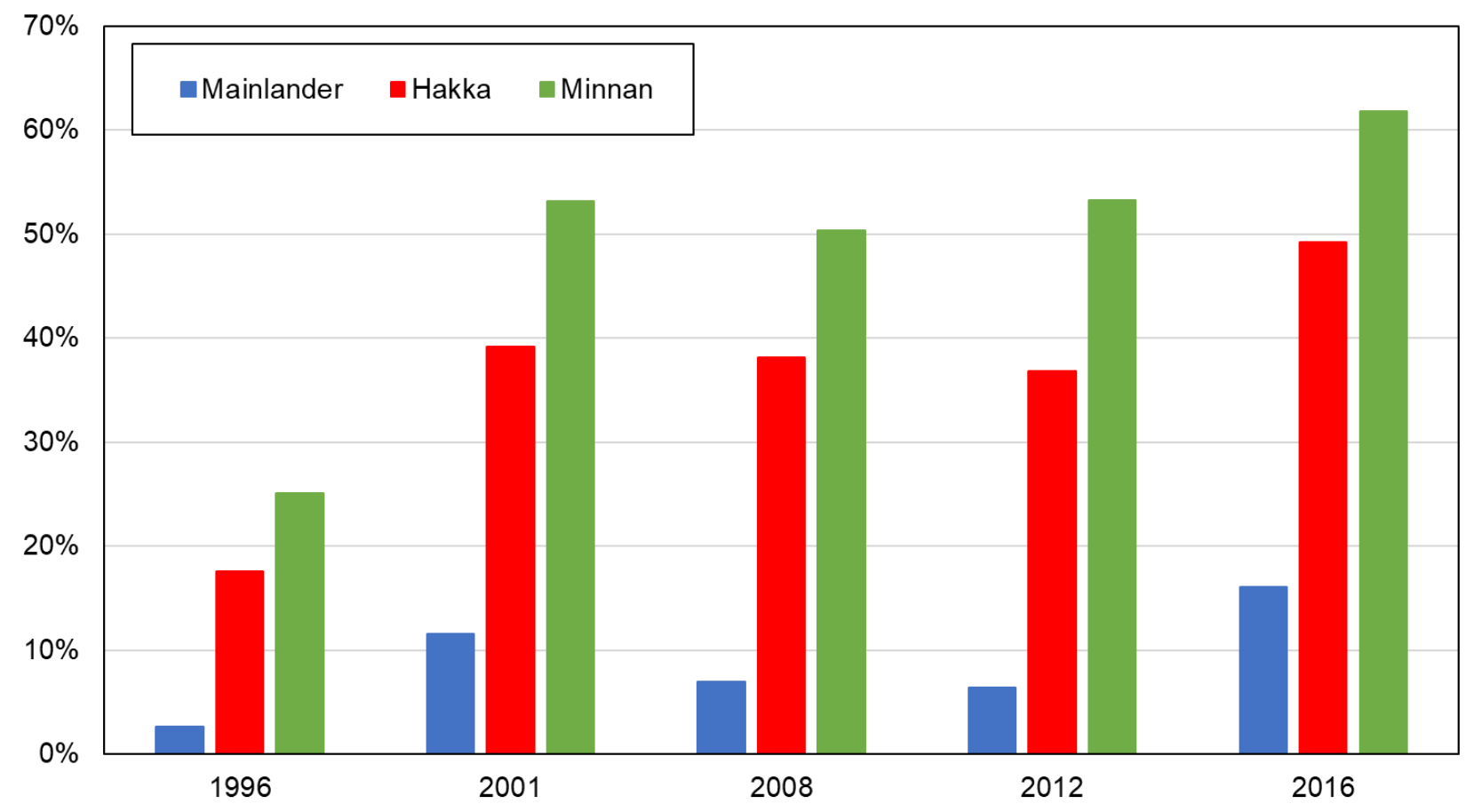

Source: authors' computations using Taiwanese political attitudes surveys. Note: the figure shows the share of votes received by the DPP by ethnicity.

The persistence of the mainlander-native gap since 1996, which has divided the party system into a previously privileged minority and a previously discriminated majority, bears similarities with the party systems of Malaysia and South Africa, where Muslim and Black majorities have respectively been represented by the dominant National Coalition and African National Congress (ANC). However, at least three main differences between Taiwan and these two countries are worth noting. First, as explained above, the ethnic cleavage in Taiwan is almost completely orthogonal to economic and social inequalities. While in Malaysia and South Africa, ethnic cleavages have been a form of class cleavage, this has not been the case in Taiwan. Instead, as explained above, ethnic divides have been entirely based upon the question of 
unification with China. Secondly, identity politics in Taiwan have not been triggered by conflictual relations between ethnic groups or by social segregation. The key distinguishing factor between mainlanders and native Taiwanese is not primarily social or economic: it remains intrinsically connected to political attitudes towards foreign policy.

Figure 8 - The ethnic cleavage in Taiwan

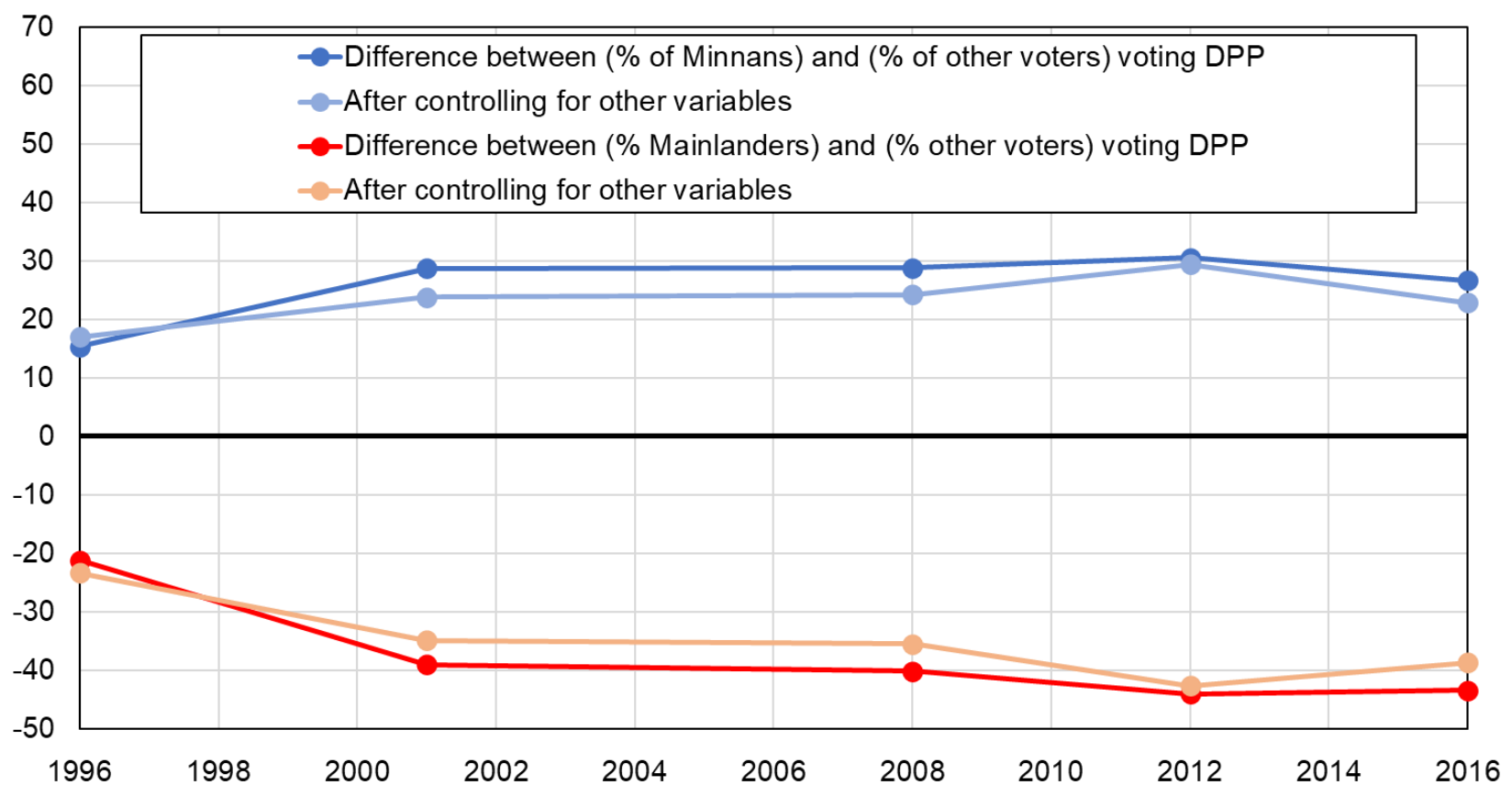

Source: authors' computations using Taiwanese political attitudes surveys.

Note: the figure shows the difference between bias towards the DPP among Minnans and Mainlanders, before and after controlling for income, education, age, gender, employment, marital status, union membership, religion, and region of residence.

Thirdly, it is remarkable to see that unlike South Africa or Malaysia, where more than 80 percent of the majority group - Blacks in South Africa, Muslims in Malaysia - have generally supported the dominating coalition, the KMT has succeeded not only in keeping its traditional support from mainlanders, but also in gaining support from a stable 40 to 50 percent of Minnans, and 50 to 60 percent of Hakkas. In that respect, when put in comparative perspective, the ethnic cleavage in Taiwan appears to be strong, but it would be exaggerated to say that it structures political divisions, given than the native Taiwanese population, which represents nearly 90 percent of the electorate, is almost evenly distributed across the two main parties. 
Democratization in Taiwan has also come with the emergence of regional divisions; as shown in Figure 9, the Southern region has always been more likely to vote for the DPP than the rest of island. This gap peaked in 2008 at 20 percentage points and seems to have declined since then, but still amounted to 10 percentage points in 2016. Controlling for other sociodemographic variables, and in particular ethnicity, reduces this gap significantly - mainly because there are more Mainlanders in the Northern and Middle regions than in the East and South - but not completely, so that residual regional identities appear to matter in determining vote choice.

Figure 9 - The regional cleavage in Taiwan

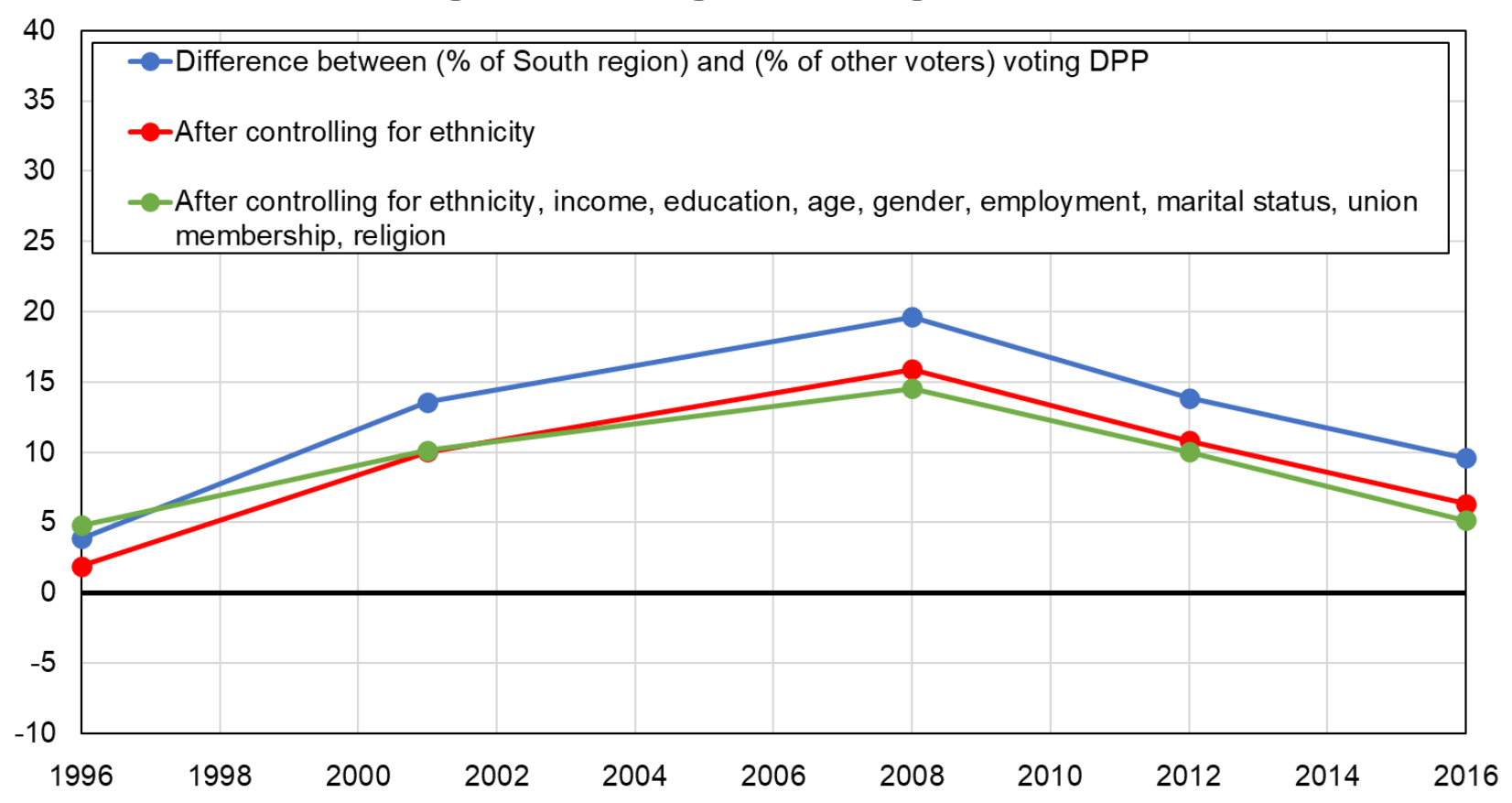

Source: authors' computations using Taiwanese political attitudes surveys.

Note: the figure shows the difference between the share of South region residents and the share of residents of other regions voting for the DPP, before and after controlling for other variables.

While ethnicity is a poor proxy for economic resources, regional inequalities in Taiwan are strong. According to the surveys at our disposal, there was a significant relationship between region of residence and position in the income distribution, both in 1996 and 2016: for instance, Southern region residents represented about 41 percent of the electorate in the bottom quintile, 
compared to only 18 percent of top 20 percent Taiwanese earners. ${ }^{29}$ These inequalities have risen since the 1990s, with the Southern and Central regions lagging behind the North, a divergence which has been attributed to the rise of the ICT sector and to increasing cross-Strait economic integration (Anderson and Klinthäll 2012). Therefore, spatial differences in voting behaviors do seem to have represented a parallel political cleavage, partially based upon historical ethnic locations, but also potentially rooted in economic inequality.

\section{Towards Class Cleavages?}

Regional inequalities and the corresponding partisan divide that they seem to have generated bears the question of class cleavages. Has the China question been so omnipresent as to entirely obliterate political representations of economic inequality, or has Taiwan's party system represented divisions between rich and poor in recent elections? This has been a debated question: some studies have argued that parties have increasingly focused on the economy independently from the question of relations with China, while others have shown evidence that voters' opinions on economic questions have been mediated by their vision of the independence/unification question. ${ }^{30}$

Figure 10 plots the relative bias of lower-educated and low-income voters towards the DPP. With the exception of 1996, when the DPP was more supported by high-income and highereducated voters, poorer and less educated voters have been more likely to vote for the DPP by 5 to 15 percentage points. As in the case of regional divides, the gap reached its peak in 2004 and seems to have declined since then.

\footnotetext{
${ }^{29}$ On the composition of income quintiles by region of residence, see appendix Figures B19 and B20.

${ }^{30}$ See Wu (2013), who argues that slower growth and rising unemployment have led parties to put greater emphasis on wealth gaps. However, quantitative evidence from survey data does not suggest that opinions on social welfare affect attitudes towards trade with China once opinions towards the unification/independence are controlled for, which suggests that attitudes about trade agreements are primarily about China rather than economics: see Achen and Wang (2017).
} 
Figure 10 - Vote for DPP among low-income and lower-educated voters

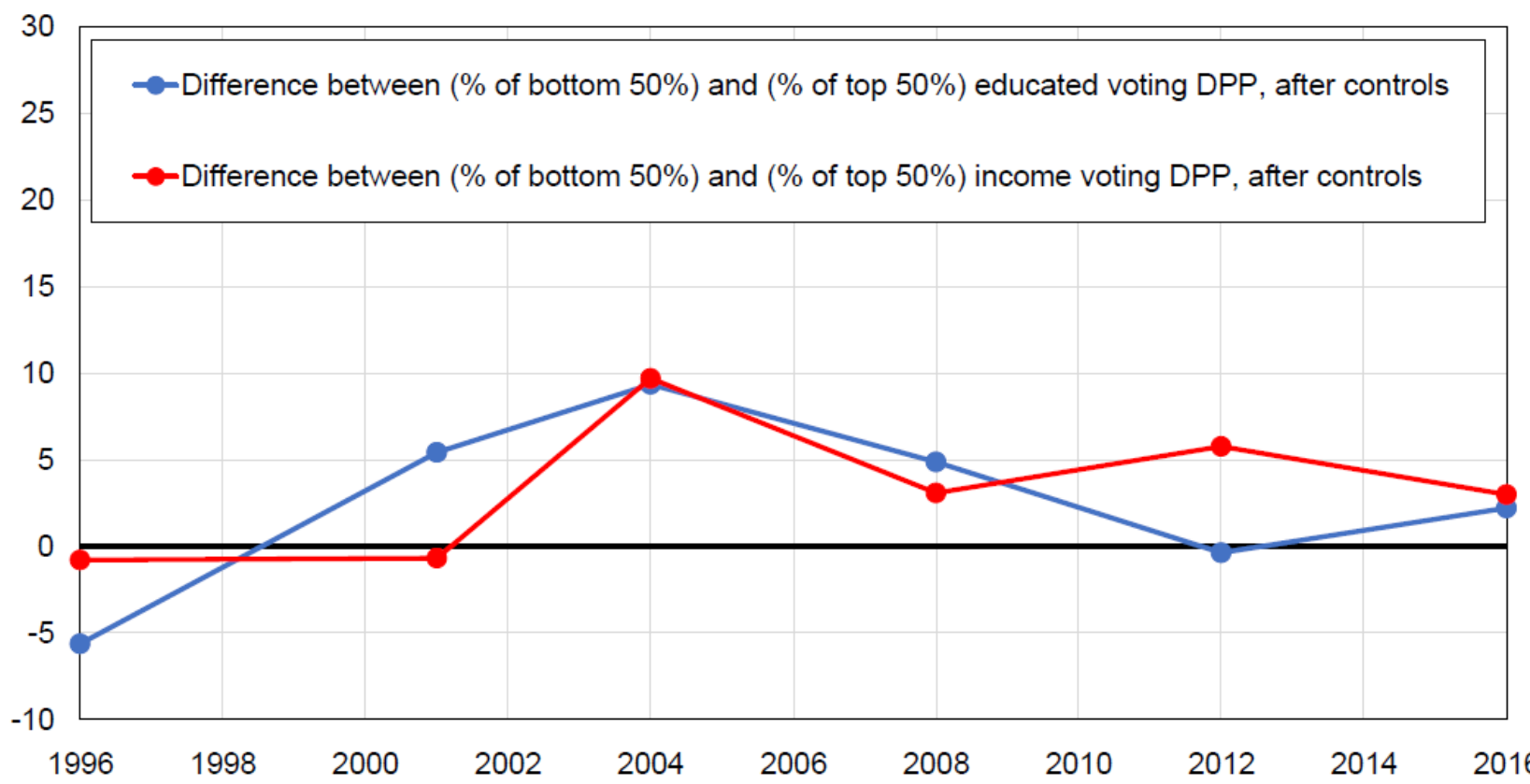

Source: authors' computations using Taiwanese political attitudes surveys.

Note: the figure shows the bias of low-income and low-educated voters towards the DPP, after controlling for income/education, ethnicity, age, gender, occupation, marital status, union membership, religion, and region.

The rise of and fall of regional, educational, and income divides provide suggestive evidence that polarization in Taiwan has been primarily framed by the independence/unification cleavage, rather than by economic issues. The rise of the radically pro-independence Trade Solidarity Union in 2001 led the DPP to strategically shift to a more pro-independence stance before the 2004 election, notably by proposing a referendum requesting the government to continue applying to UN membership under the name of Taiwan, as well as a new constitution. Meanwhile, there is no evidence that the electorate was more polarized on economic or welfare issues in 2004 and 2008. On the contrary, distributional issues were arguably more salient in the post-crisis period; one would therefore expect class cleavages to have risen since 2008, which is the opposite of what we observe. Our results are more consistent with recent evidence showing a similar inverted U-shaped trend in voter polarization on the independenceunification issue (Wang 2019). 
In summary, our results show that lower-educated, low-income, and Southern voters have been significantly more likely to vote for the pro-independence camp since the early 2000s, and this was even more the case in elections where partisan divides on the independence/unification issue were stronger. These findings are completely the opposite of what we find in Hong Kong where pro-democratic votes have been higher among higher-income and higher-educated voters (see below). This difference arguably lies in the fact that the China question has interacted with other dimensions of political conflicts in very different ways in the two territories: while in Hong Kong, pro-Beijing forces have been more popular among older generations and immigrants, two groups on average poorer than the rest of the population, the Kuomintang has on the contrary historically been the party of the mainlander elite, a divide that the DPP seems to have carried into the present day by representing not only formerly oppressed ethnic groups, but also disadvantaged voters and poorer regions. Additionally, while economic patronage from Beijing in Hong Kong may make integration more appealing to low-income voters, increasing competition from mainland China's industries may be negatively perceived by industrial workers in Taiwan, in a perhaps comparable way to the rise of anti-globalization sentiments among the working class in Western democracies.

Interestingly, age does not seem to have played a key role in Taiwan, and there is in fact evidence that a sizable share of new generations has turned to abstention rather than to greater political mobilization as in Hong Kong (Achen and Wang 2019). ${ }^{31}$ This may however be gradually changing in recent years, as students were notably omnipresent in the 2014 Sunflower Student Movement against the passing of the Cross-Strait Service Trade Agreement with Beijing. The New Power Party which emerged from this movement captured five seats in the

\footnotetext{
${ }^{31}$ We show in the online appendix that younger voters have been generally more supportive of the DPP, but this bias is much lower than in the case of Hong Kong. Notice however that this view is static and considers younger generations at each point in time. There is evidence that the rise of pro-independence views has been partially driven by the replacement of older cohorts by new cohorts of voters, who tend to be more in favor of independence: see Huang (2019).
} 
legislative Yuan in 2016, but only 3 in 2020, which does not suggest that it is becoming a new significant political force. ${ }^{32}$

\section{Hong Kong}

Hong Kong was handed over to the People's Republic of China (PRC) by the United Kingdom in 1997, in application of the Sino-British Joint Declaration of 1984. According to the declaration, the Hong Kong Special Administrative Region (HKSAR) was to fall under the principle of "one country, two systems": the city's capitalist system would remain unchanged for a period of fifty years, and existing civil rights and freedoms would be guaranteed. The government of the HKSAR would be composed of local inhabitants and elected democratically. Several promises were made by Chinese officials detailing how and when such democratization would take place, but none were fulfilled (Ma 2020).

China's refusal to respond to democratic aspirations, together with the rise of a Hong Kong identity increasingly viewed in exclusionary rather than complementary to Chinese identity, initiated a gradual process of political polarization. Colonial Hong Kong had been widely depicted by political scientists as a passive society, an "apathetic polity" where the culture of "utilitarian familism" encouraged a materialistic, individual-oriented lifestyle with minimal political participation (Cooper and Lam 2018). ${ }^{33}$ This view proved to be outdated in 2003, when half a million of protestors joined in the streets to oppose the national security bill widely perceived as a threat to civil liberties. The trend towards radicalization and political activism continued thereafter, from the occupation of the government headquarters by students in 2007 to the Umbrella movement in 2014 (Ma 2020). The 2019-2020 protests triggered by the Fugitive Offenders amendment bill, which would have allowed the extradition of criminal

\footnotetext{
${ }^{32}$ On the New Power Party, see in particular Chen and Liao (2019).

33 The concept of "utilitarian familism" originates from the work of Siu-kai Lau in the 1970s and 1980s, in particular Lau (1978).
} 
suspects to mainland China, marked the culmination of mass mobilizations, with millions taking to the streets in June 2019 (Kleefeld 2019).

Political cleavages in Hong Kong, as in Taiwan, have therefore been in large part structured by citizens' visions of, and interactions with, mainland China. The "China factor", according to Ma Ngok, has shaped Hong Kong politics in three dimensions: an ideological/identity dimension, a power-structural dimension, and an organizational resource dimension. Ideologically, attitudes towards the central government have been the main determinants of electoral behaviors for the two main coalitions, the pro-democracy camp supporting democracy, freedom, and autonomy, and the pro-Beijing camp supporting stability and loyalty to Beijing. The power-structural dimension refers to the PRC's ultimate control of the rules of the electoral game, which have been exploited to show a façade of democracy while maintaining the effective control of political resources and the legislature. The organizational resource factor refers to Beijing's ability to mobilize material and social resources to gain both support from the local population and votes in popular elections, which allowed the pro-Beijing camp to get a growing share of votes and seats (Ma 2016).

In structuring the opposition between the pro-democracy and the pro-Beijing camps, the main divide has been generational. A distinct local subculture of "Hongkongers" (Heunggongyahn) associated with consumerism and Cantonese pop culture had emerged as early as the 1970s, but it was perceived as complementary, rather than conflictual, with the preexisting pan-Chinese consciousness that prevailed (Veg 2017). By contrast, the generations that grew up in the 1980s and 1990s started to envision Hong Kong identity as increasingly unique and partially incompatible with the political and cultural specificities of the mainland. University students, in particular, were at the heart of the protests that took place between 2003 and 2019 (Sing 2020).

Importantly, the generational divide in Hong Kong has not only been about identity: it has been reinforced by other dimensions of political conflict. Key actors in the protest movements were what the journalist Paul Mason called the "graduate with no future", students disillusioned with 
their economic and social perspectives in a city characterized by soaring housing prices and widening income disparities (Mason 2012). Rapid immigration from the mainland also fostered xenophobic sentiments against the newcomers, which strengthened the exclusivist vision of a "Hong Konger identity" incompatible with integration with China (Ma 2015). Hong Kong politics have therefore combined an integration/disintegration dimension similar to that observed in Taiwan, an economic dimension, and an internationalist/nativist dimension.

In this section, we use existing political attitudes surveys to study how these different cleavages have changed between 1998 and 2016. Three main findings emerge from our analysis. First, in line with qualitative accounts, we document extreme and rising generational divides, almost unparalleled in comparative perspective, which trump the effects of most other socio-structural factors in determining party affiliations. Secondly, we show that China-born individuals are significantly more likely to vote for pro-Beijing parties than for the pan-democracy camp, but this effect is not as strong as one would expect. The age gradient holds among both groups, which suggests that processes of socialization among young mainlander cohorts matter in shaping their political attitudes. Finally, we find that younger voters are significantly more likely to oppose closer integration with China, to feel exclusively Hong Konger, to oppose immigration from the mainland, and to think that income inequality is an important societal problem. Integration with China and Hong Konger identity appear to be much more divisive across generations, however, which suggests that cleavages related to institutions and sovereignty are more pronounced than distributional or immigration issues.

\section{Unachieved Democratization and the Transformation of Hong Kong's Party System}

After more than 150 years of colonization by the British, with the exception of a brief period of Japanese occupation in the 1940s, Hong Kong reintegrated China in 1997 under the principle of "one country, two systems". Democratization and the formation of political organizations had nevertheless already started in the 1980s, as the Sino-British negotiations of 1982-1984 politicized the Hong Kong population. The Tiananmen Square protests in mainland China in 1989, among other factors, had consolidated the strength of pro-democracy political parties, 
and the United Democrats of Hong Kong won by a landslide in the first direct elections of the Legislative Council (LegCo) in 1991, receiving 45 percent of votes - and 62 percent for all prodemocracy parties combined (see Figure 11). ${ }^{34}$ Seven LegCo elections have been held since then. Pro-democracy parties have always received more than 55 percent of the vote, while the pro-Beijing camp has been able to grow from 15 percent in 1991 to 40 percent in 2016 thanks to the decline of independent candidates.

Figure 11 - Election results in Hong Kong, 1991-2016

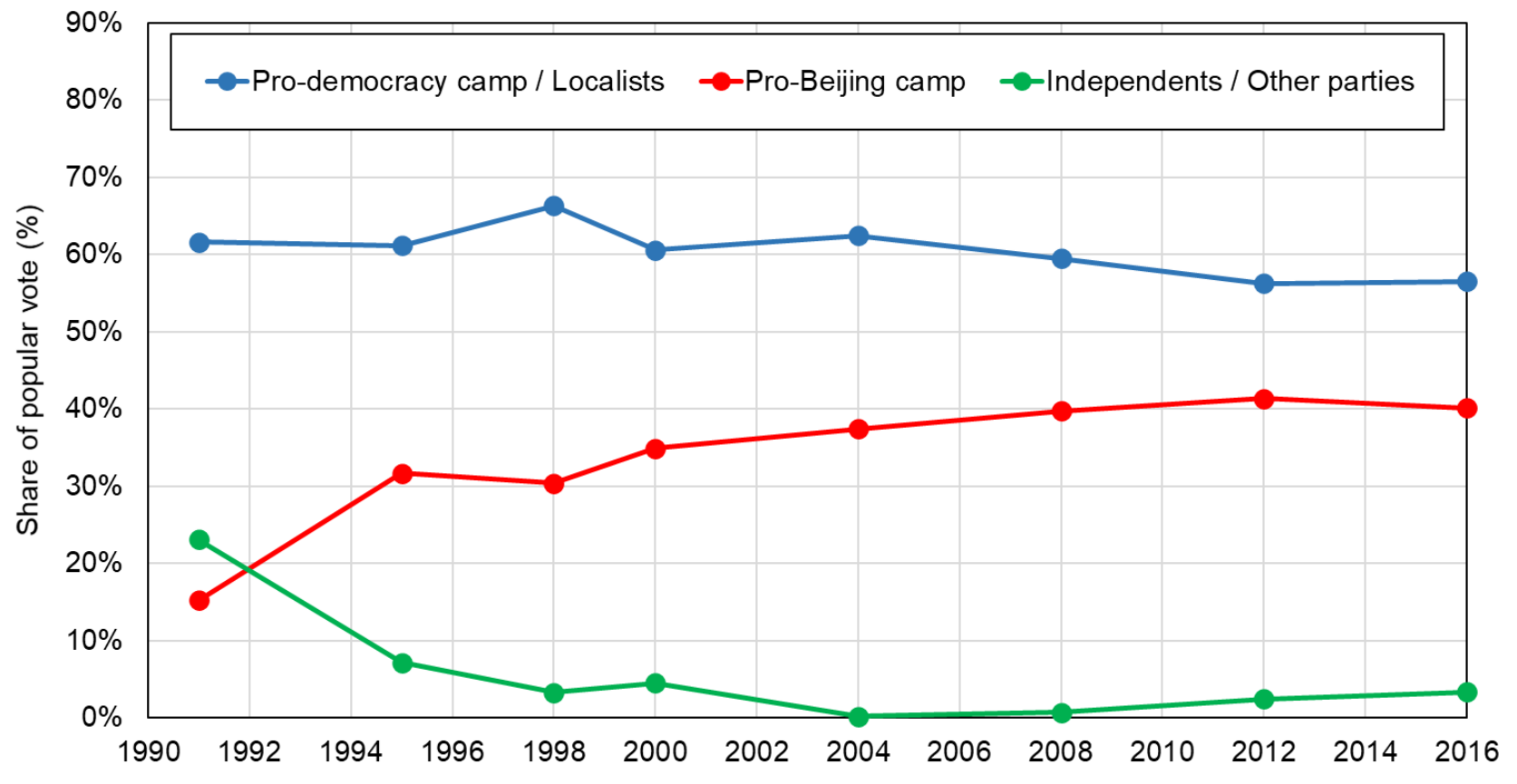

Source: authors' computations using official election results.

Note: the figure shows the share of votes received by selected groups of Hong Kong political parties in geographical constituencies in Legislative Council elections between 1991 and 2016.

However, the pro-Beijing forces have always managed to retain control over political power, mainly due to three factors. First, Hong Kong's electoral system has disproportionally benefited to the pro-Beijing camp. Half of the 70 members of the Legislative Council, the unicameral legislature of the HKSAR, are elected through five geographical constituencies under a proportional representation system which allocates seats according to the vote shares received

\footnotetext{
${ }^{34}$ On the history of political parties in Hong Kong, see for instance Ma (2007).
} 
by parties. The other half are elected through functional constituencies representing specific interest groups such as big businesses, professional sectors, or labor unions, which have been much more supportive of the pro-Beijing government. ${ }^{35}$ In 2016, functional constituencies were elected by about 230,000 individuals or corporate entities, compared to 3.8 million registered voters in the geographical constituencies. This allowed the pro-Beijing camp to get 40 of the 70 LegCo seats despite obtaining only 40 percent of votes in geographical constituencies. ${ }^{36}$

Secondly, the Chief Executive, the head of government, is elected from a restricted pool of candidates supportive of the Central Government by a 1200-member electoral college of individuals and interest groups. This has allowed the executive branch of government to be completely controlled by Beijing. The joint declaration of 1984 stipulated that the Chief Executive would be eventually selected on the basis of local consultations or elections, which raised hope of democratization among younger generations. In fact, the election of the Chief Executive by universal suffrage without pre-screening of candidates was one of the key demands of protestors in the Umbrella movement of 2014 (Ma 2020).

Thirdly, Beijing has been able to mobilize electoral resources to secure a growing share of popular votes. Pro-Beijing local networks have cultivated members' support through material benefits and social services, which they have been able to dispense thanks to subsidies received from the mainland. They have also been highly effective at optimizing the organization of party lists and the allocation of candidates to constituencies, which in 2016 allowed them to get more

\footnotetext{
35 The system used for geographical constituencies is a proportional system with Largest Remainder method and Hare quota. Under the PR system, seats are first awarded to the parties or lists that get above the quota, and the remaining seats are awarded to those who have the most remaining votes after the votes needed to reach the quota are counted. The Hare quota corresponds to a quota of $1 / \mathrm{N}$ if a constituency has N candidates. See Ma (2007).

${ }^{36}$ Notice that five of the LegCo members from the functional constituencies (the District Council (Second) Function Constituencies) are returned by a closed list proportional representation system where Hong Kong as a whole is considered as a one constituency. Candidates must be elected District Council members who are nominated by no less than 15 other elected District Council members, and voters are registered GC electors who are not registered in other FCs. See for instance Pang-kwong (2016).
} 
seats than pan-democrats in geographical constituencies, despite receiving a lower vote share (Ma 2017). Immigration from the mainland has also boosted support for the pro-Beijing camp: immigrants tend to be more supportive of the status quo, and they have successfully been coopted by pro-establishment parties (Wong, Ma, and Lam 2018).

As in Taiwan, while the China factor has been the main axis of electoral competition between parties at least since the early 1990s, there have been significant changes in the issues debated by political actors. In the 1991 and 1995 LegCo elections, attitudes towards the Chinese government, the Tiananmen crackdown, and democratization were the main distinguishing factors between parties and voters (Leung 1993; Leung 1996). Democratization became an even more important issue in the context of the 2003 protests against the security bill; and electing the Chief Executive and the LegCo by universal suffrage was the main demand of the prodemocracy movement in the 2004 elections (Ma 2020). After the Beijing Olympics of 2008, the China factor changed again, as anti-China sentiments grew stronger and new currents of "localism" emerged. Movements of "progressive localism" renewed demands for selfdetermination and the implementation of genuine democracy. Movements of "anti-China localism" born after the 2014 Umbrella protests went further, questioning for the first time the “one country, two systems" principle and even proposing the sovereign independence of Hong Kong as a new nation (Chen and Szeto 2015). A "localist" camp emerged in the LegCo in the 2016 legislative election, receiving 19 percent of votes and winning six seats in geographical constituencies - as compared to 36 percent and 13 seats for the pro-democracy camp. Politics in Hong Kong have therefore been characterized by growing polarization, as claims are gradually shifting from autonomy and democracy to cultural exclusivism and even national sovereignty (Kaeding 2017; Ortmann 2018).

\section{The Rise of Generational Divides}

We now turn to the analysis of electoral behaviors in Hong Kong by using political attitudes surveys available from the Comparative Study of Electoral Systems, which cover the LegCo elections of 1998, 2000, 2004, 2012, and 2016. Figures 12 and 13 reveal extreme generational 
gaps in support for the pro-democracy camp and localists, which already existed in 1998 but seem to have reached a peak in 2012 and 2016. Figure 12 shows the share of votes received by the pro-democracy camp between 1998 and 2016 by decade of birth. Support for pro-democracy forces among voters born in the 1940s to 1960s has decreased steadily, from 70 to 80 percent to 30 to 50 percent in 2016, while nearly $90 \%$ of voters born in the 1990 s voted pro-democracy in 2016. This implies that the generational composition of the pro-democracy camp has changed dramatically since 1998, as a significant share of older generations have turned towards proBeijing parties, while new generations have almost perfectly compensated this decline.

While young voters were already more likely to support pro-democracy parties by 17 percentage points in 1998; this gap has grown to 32 percentage points in 2016 (see Figure 13). Controlling for other variables, and in particular for education and marital status, reduces the gap to 19 percentage points in 2016, mainly because younger voters are more educated and more likely to not be married. Age, education, and marital status are tightly linked to each other, given that the core voting base of the democrats tend to be students or recent university graduates. Yet age still has a substantial and growing independent effect on vote choice.

Figure 12 - Vote for pro-democracy by decade of birth

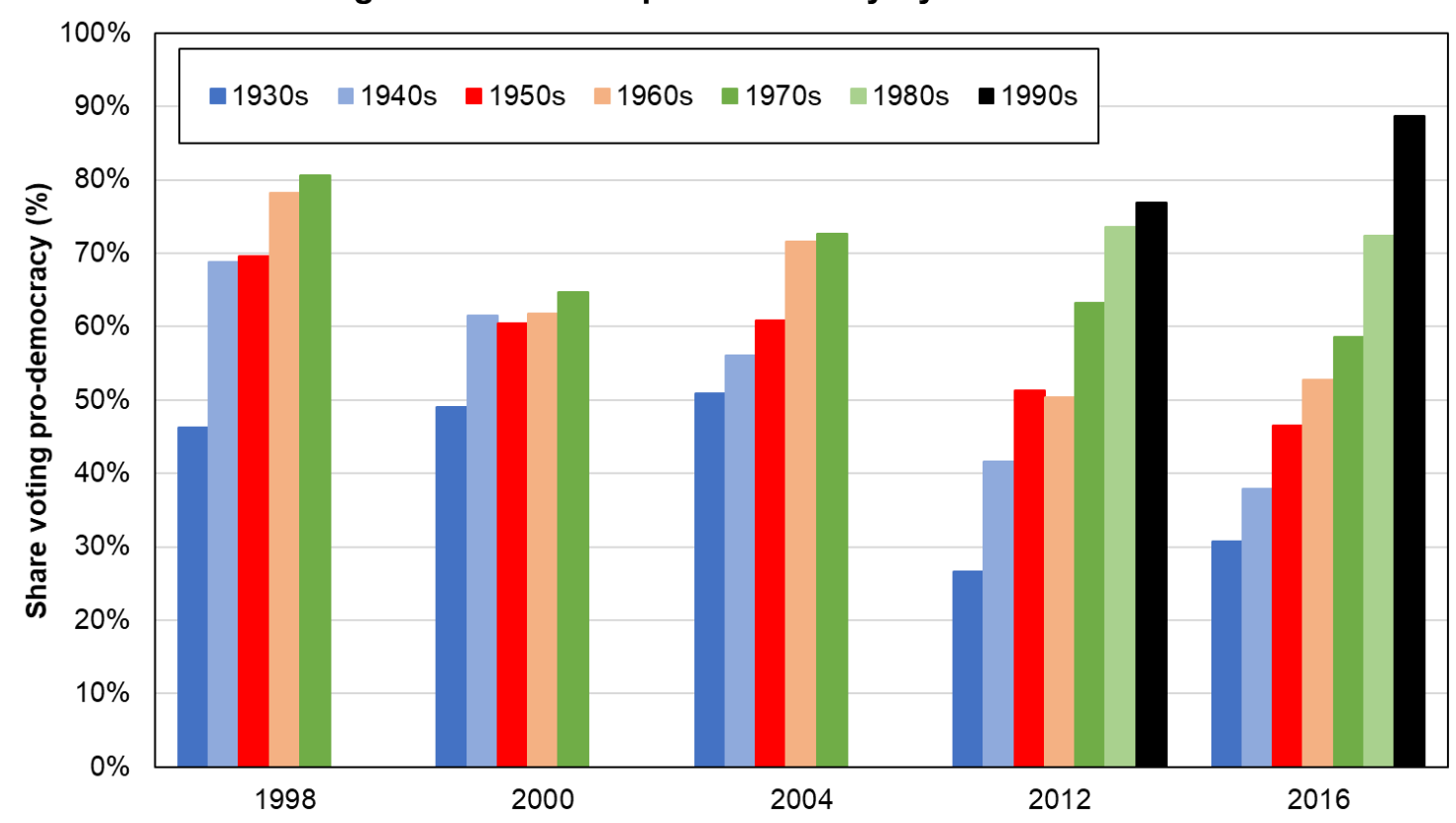

Source: authors' computations using Hong Kong political attitudes surveys.

Note: the figure shows the share of votes received by the pro-democracy camp by decade of birth. 
Figure 13 - The rise of generational cleavages in Hong Kong

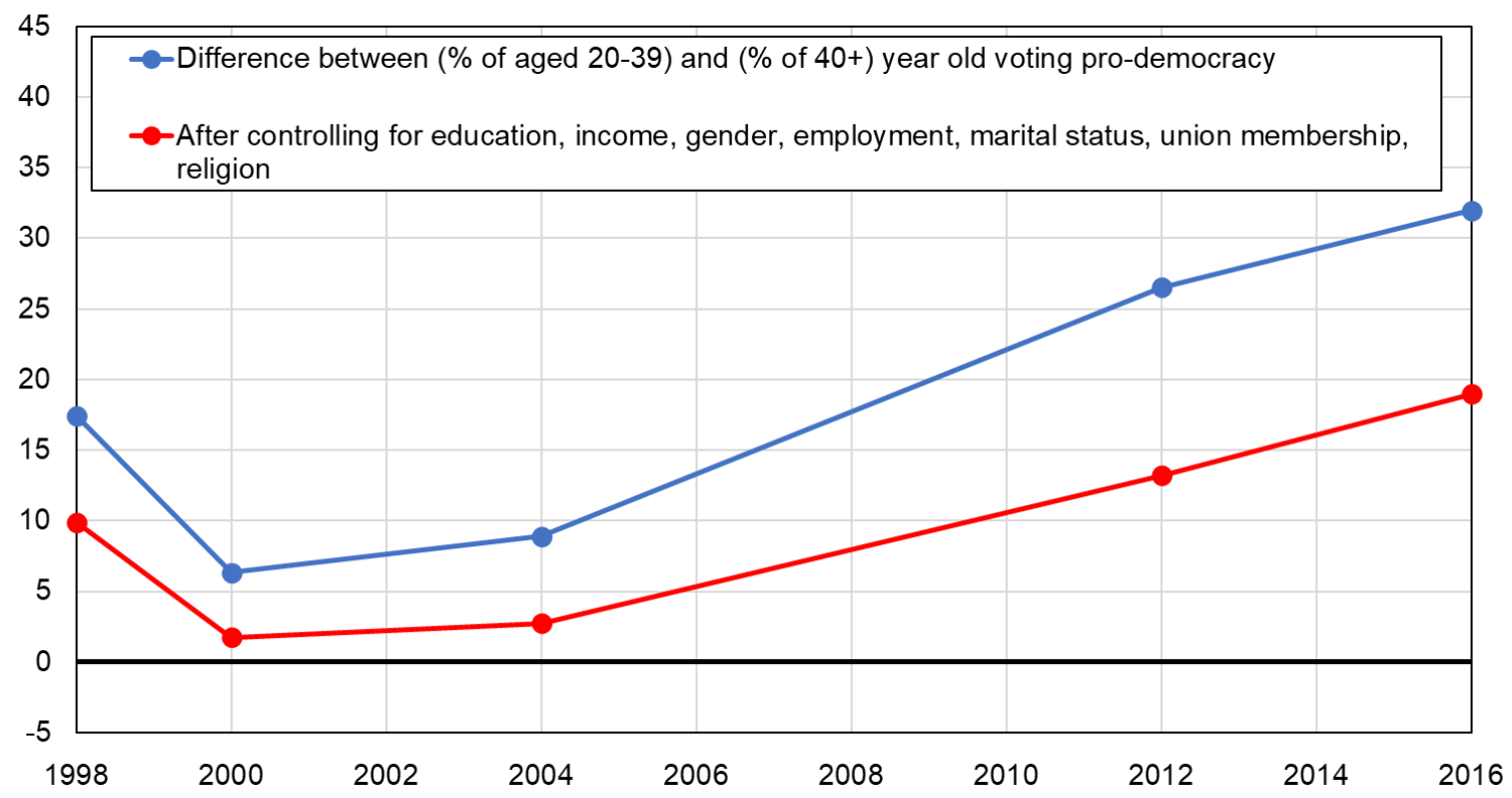

Source: authors' computations using Hong Kong political attitudes surveys.

Note: the figure shows the difference between the share of voters aged 20-39 and the share of voters older than 40 voting for the pro-democracy camp, before and after controlling for other variables.

These results are in line with our previous qualitative account: the heart of the pro-democracy movement lies in younger generations, who are much more likely to develop a feeling of separate, and more recently exclusivist, Hong Kong identity, as well as more supportive of democracy, as we will discuss at the end of this paper. In comparative perspective, the generational divide in Hong Kong appears to be particularly strong and persistent. Such gaps are only visible in a handful of cases, such as in South Korea since the 2000s (see above), in the United Kingdom in the last elections (Piketty 2018), or in Japan in the early postwar decades (Gethin forthcoming). Generational divides are generally found to be associated with center/periphery or internationalist/nativist cleavages, such as the Bloc Québécois in Canada or the Brexit vote in the United Kingdom, two dimensions of political conflict which clearly have an exceptionally acute importance in Hong Kong politics. ${ }^{37}$

\footnotetext{
${ }^{37}$ Interestingly, as noted by Cooper and Lam, the issues of identity, sovereignty, cultural change, and attitudes to immigration have some similarities to the political vocabularies of the new right populism in the West. In Europe and North America these ideas have found higher levels of support amongst older voters, but "the novelty of the
} 
Simultaneously, the shift of older generations towards the pro-Beijing camp may have been driven by two factors. First, it may be that youth radicalization, mounting protests, and the ideological transformation of pro-democracy movements have led older generations, who may be more risk averse and more moderate in their reformist aspirations, to shift to pro-Beijing parties. The material and social resources deployed by pro-Beijing networks to gain votes may also have been more effective at convincing older cohorts to support the status quo than younger voters. Secondly, massive immigration from mainland China has changed the composition of the electorate. As migrants tend to be older and more supportive of pro-Beijing parties, immigration waves mechanically lead to lower support among older cohorts. Competition between the pro-democracy camp and the pro-Beijing camp could in this dimension be conceptualized as a "race" between immigration and generational renewal. Unfortunately, data on location of birth is only available since 2012, so this cannot be formally tested. However, as we show below, the cleavage between mainlanders and natives is not sufficiently strong to account for this transformation alone, so that the first factor must necessarily explain part of the change.

It is also important to stress that while concerns about rising housing prices and economic insecurity have been strong determinants of pro-democracy support and protest participation among young natives, this does not imply that the pro-democracy/pro-Beijing opposition has represented class cleavages. In fact, according to the surveys at our disposal, support for the pro-democracy camp is more pronounced among highest-educated and top-income voters: in 2016, tertiary-educated were more likely to vote for pro-democrats by 27 percentage points, and top 10 percent income earners by 5 percentage points. The bias of university graduates towards the pro-democracy camp is mainly driven by the fact that younger voters are more educated, yet it does not disappear completely after controlling for age. Income is a poor

Hong Kong experience lies in how the relationship between social demography and the emergence of nativism appears to be powerfully inverted" (Cooper and Lam 2018, 8-9). It is also important to note that the growth of nativism in Hong Kong has often come in reaction to an aggressive nationalism coming from Beijing. 
predictor of electoral behaviors overall, because age is only weakly correlated to social class, and because poorer immigrants from the mainland tend to support the pro-Beijing camp. ${ }^{38}$

\section{Immigration and the internationalist/nativist cleavage}

Immigration from mainland China to Hong Kong since 1997 has been substantial has been the subject of intense political debates (Wong, Lee, Ho, and Clarke). Under the "one-way permit" policy, mainland Chinese who want to migrate to Hong Kong must apply through mainland authorities. If the application is approved, they can legally migrate, and they usually obtain permanent residence status after seven years, along with the right to vote. A maximum of 150 permits per day are issued by the relevant Chinese departments, corresponding to an annual quota of 54,000, which has led to a large and sustained influx of mainland immigrants in the last decades (Wong, Lee, and Ho 2019). The government has also implemented other immigration schemes since the 2000s, such as the Quality Migration Admission Scheme, which allows high-skilled migrants to gain residence in Hong Kong even without an employment contract, and it has provided opportunities for mainland students to pursue higher education in the city. Before 2015, the enforcement of the one-child policy in mainland China also led families to emigrate to give birth, leading to heated controversies in Hong Kong (Ma 2015). In 2016, about one in seven of the city's residents was an immigrant who arrived from China after 1997, and according to the surveys used in this paper, over a quarter of the electorate in total was born in the mainland (arriving before or after 1997) (Downes 2018). ${ }^{39}$

Chinese immigrants face numerous difficulties when arriving in Hong Kong, from social prejudice to discrimination. They are usually less educated, older, and poorer than natives, and

\footnotetext{
${ }^{38}$ A number of figures on education and income are available in the appendix: see in particular Figures C10, C11, $\mathrm{C} 12, \mathrm{C} 20, \mathrm{C} 21, \mathrm{C} 22, \mathrm{C} 23$, and C24. Notice however that the peak in housing prices has created a sharp divide between homeowners and tenants, the latter being much more likely to support the pro-democracy camp: see Wong and Wan (2018).

${ }^{39}$ See appendix Table C2 for the share of individuals born in Hong Kong, China, and other countries.
} 
they are overrepresented in low-skilled jobs in the service sector. According to the surveys at our disposal, the share of mainlanders with tertiary degrees was two times lower than that of natives in 2016. Immigrants amounted to 29 percent of the poorest 20 percent of the adult population in terms of household income, as compared to 16 percent of the top quintile. Yet, growing immigration and the rise of localism together have generated strong resentment among the local population, who increasingly view the new immigrants as foreigners supporting the Beijing establishment while benefitting from the city's amenities and economic opportunities (Downes 2018). ${ }^{40}$

Figure 14 - The mainlander-native cleavage in Hong Kong

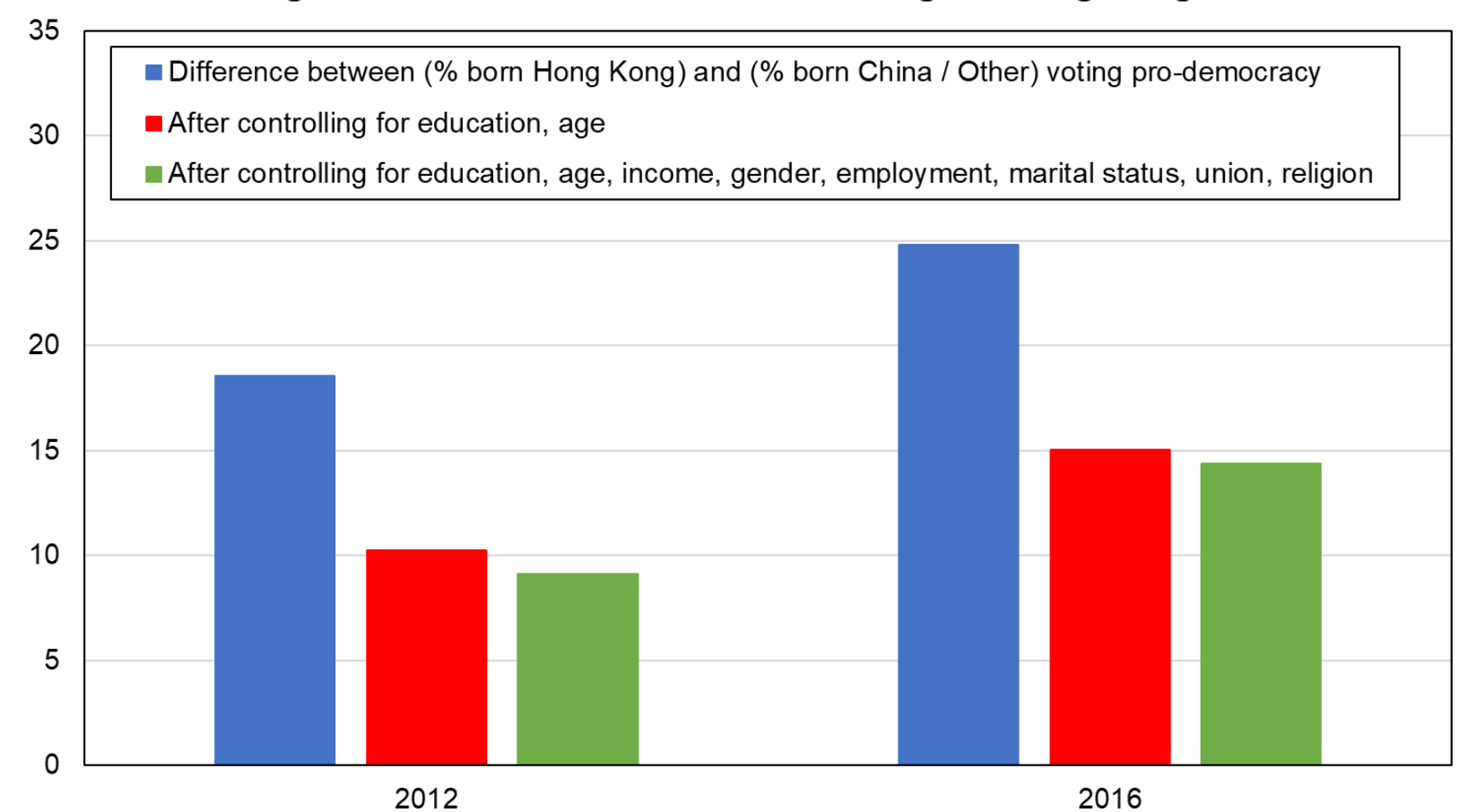

Source: authors' computations using Hong Kong political attitudes surveys.

Note: the figure shows the share of votes received by the pro-democracy camp by gender.

How strong is the mainlander/native cleavage in Hong Kong? Figure 14 shows that in 2012 and 2016, natives have been more likely to support pro-democracy parties by 20 to 25 percentage points. In 2016, for instance, 39 percent of voters born in China voted for the pro-democracy camp, compared to 64 percent of those born in Hong Kong. This difference drops significantly

\footnotetext{
${ }^{40}$ See appendix Table C5 for the summary statistics on age, income, and education by location of birth.
} 
once controlling for age and education, because immigrants are on average older than natives, and age is strongly associated with vote choice. After controlling for all available variables, the mainlander-native gap drops to about 14 percentage points in $2016 .^{41}$

Two findings emerge from this figure. First, the immigration cleavage in Hong Kong appears to be surprisingly small when put in comparative perspective. In Taiwan, for instance, we saw that the mainlander-native cleavage was much larger, with less than 15 percent of mainlanders voting for the DPP as compared to 60 percent of Minnan voters. This is again much smaller than the massive differences in voting behaviors between religious minorities and the rest of the population visible in Western democracies (Gethin, Martínez-Toledano, and Piketty 2019). In France, for instance, over 90 percent of Muslims voted for left-wing parties in 2012, compared to about 40 percent of Catholics (Piketty 2018). Therefore, while the divide between natives and immigrants does exist, its importance should not be over-emphasized.

Secondly, one might hypothesize that this small gap hides heterogeneity within generations, as older generations of immigrants could be more supportive of the pro-democracy camp than new generations, who have been the first victims of the rise of anti-immigration sentiments. However, we show in the appendix that the exact opposite holds: as much as 80 percent of immigrants from the mainland aged below 29 voted for the pro-democracy camp in 2016, compared to 28 percent of those aged 70 or above. Therefore, generational divides seem to matter much more than the mainlander-native cleavage. It also points to the role of processes of socialization, as young voters born in China may correspond to individuals who emigrated from the mainland when they were children and received their entire education in Hong Kong. Other mainlanders younger than 40 may correspond to former students who benefited from student schemes and were exposed to pro-democracy student activism. This result shows that mainlander-native cleavages cannot be explained by economic competition or opposition between immigrants and natives belonging to the same cohorts, as young natives and immigrants show comparable levels of support for the pro-democracy camp.

\footnotetext{
${ }^{41}$ See appendix Figure C13 for support for the pro-democracy camp by location of birth.
} 
Younger voters and natives are on average more educated and richer than older cohorts and immigrants respectively. As the pro-democracy camp heavily relies on support from the youth and natives, it is therefore not surprising to see that higher-income earners, and especially higher-educated voters, have been significantly more likely to vote pro-democracy (see Figure 15). These two gaps can however be almost entirely explained by these two compositional effects, even if higher-educated voters remain slightly more likely to vote for pro-democracy after controls. ${ }^{42}$

Figure 15 - Vote for pro-democracy camp among top-income and highest-educated voters in Hong Kong

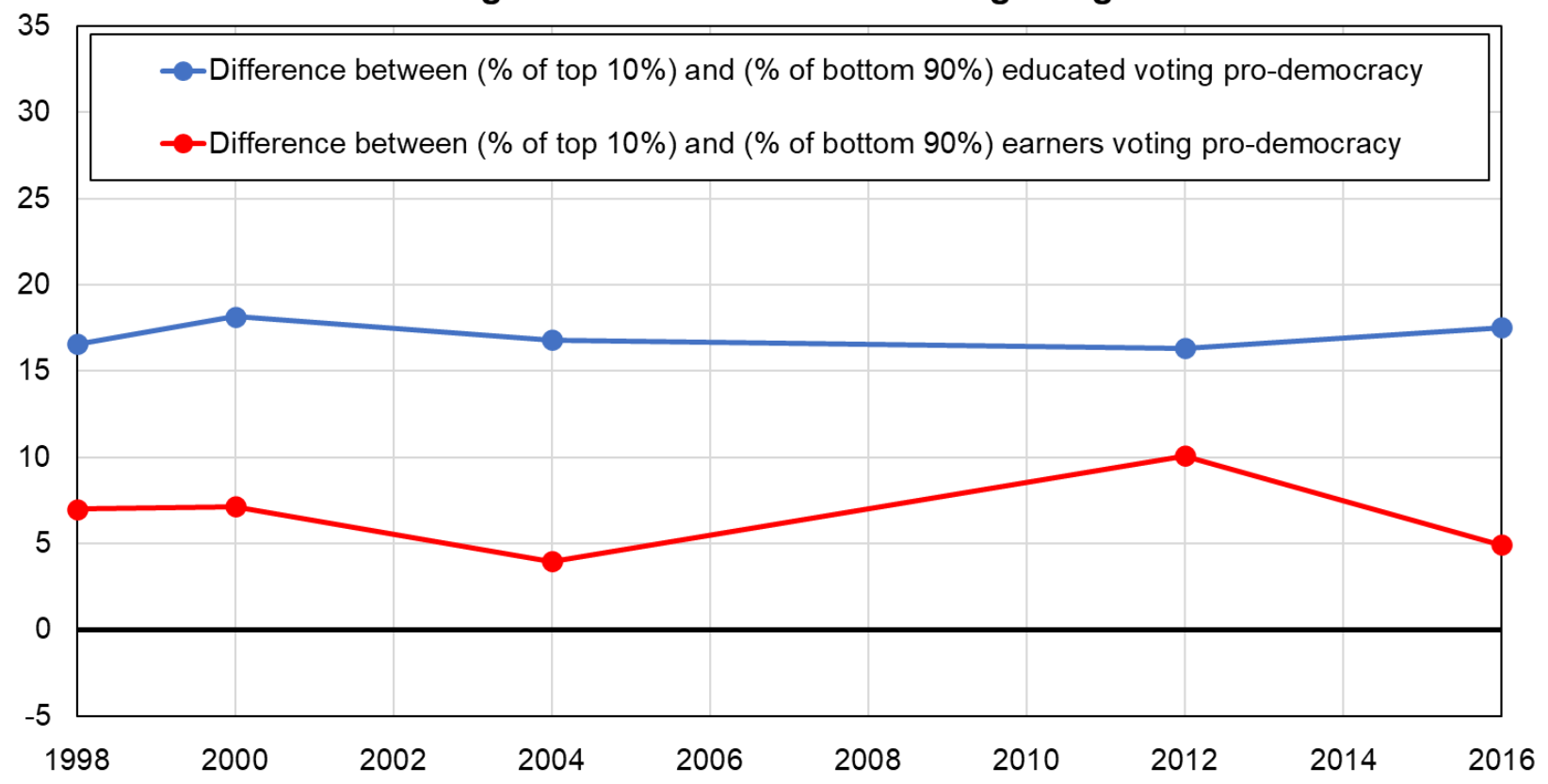

Source: authors' computations using Hong Kong political attitudes surveys.

Note: the figure shows the difference between the share of top $10 \%$ educated voters and the share of other voters voting for the pro-democracy camp.

\footnotetext{
${ }^{42}$ See in particular appendix Table C3, which shows that the effect of income on the vote falls to almost zero and is not significant after controls.
} 
Therefore, while economic concerns about rising housing prices and economic insecurity did play an important role in explaining pro-democracy support and protest participation among young natives, there is only limited evidence that economic status influences electoral behaviors beyond its interaction with age and origin, and there is even less evidence that poorer or lesseducated voters have been shifting towards the pro-democracy camp. ${ }^{43}$ This is a striking result, given that the youth are on average more concerned about income inequality (see below) and that the pro-Beijing camp is generally pictured as representing the elites (which are, it is true, numerically small and may not be adequately captured in our data). This points again to the dominance of the generational cleavage and the immigration cleavage in structuring political conflicts in Hong Kong.

\section{The Sociological Foundations of Generational Divides}

We conclude with a simple analysis of the relationship between generational divides and political attitudes. As we explained at the beginning of this section, existing studies suggest that youth radicalization in Hong Kong lies at the intersection of social, economic, and cultural concerns. Based on the Hong Kong Election Study conducted in 2015, we document in Figure 16 how opinions on Chinese integration, Chinese identity, democracy, immigration, and economic inequality vary with age.

\footnotetext{
${ }^{43}$ Notice however that the peak in housing prices may have created a divide between homeowners and tenants: see S. H. Wong and K. M. Wan, "The Housing Boom and the Rise of Localism in Hong Kong: Evidence from the Legislative Council Election in 2016," China Perspectives 3 (2018): 31-40.
} 
Strikingly, generations of voters diverge on all these issues. Younger voters are more likely to disagree or strongly disagree that closer integration with Mainland China will benefit Hong Kong. They are more likely to think themselves as only "Hong Konger", rather than "Chinese", “Chinese Hong Konger", or "Hong Kong Chinese". They are more likely to disagree or strongly disagree that Hong Kong has a democratic political system, more likely to agree or strongly agree that Hong Kong has too many immigrants coming from China, and more likely to cite income inequality as one of the three most important problems facing Hong Kong at the present time.

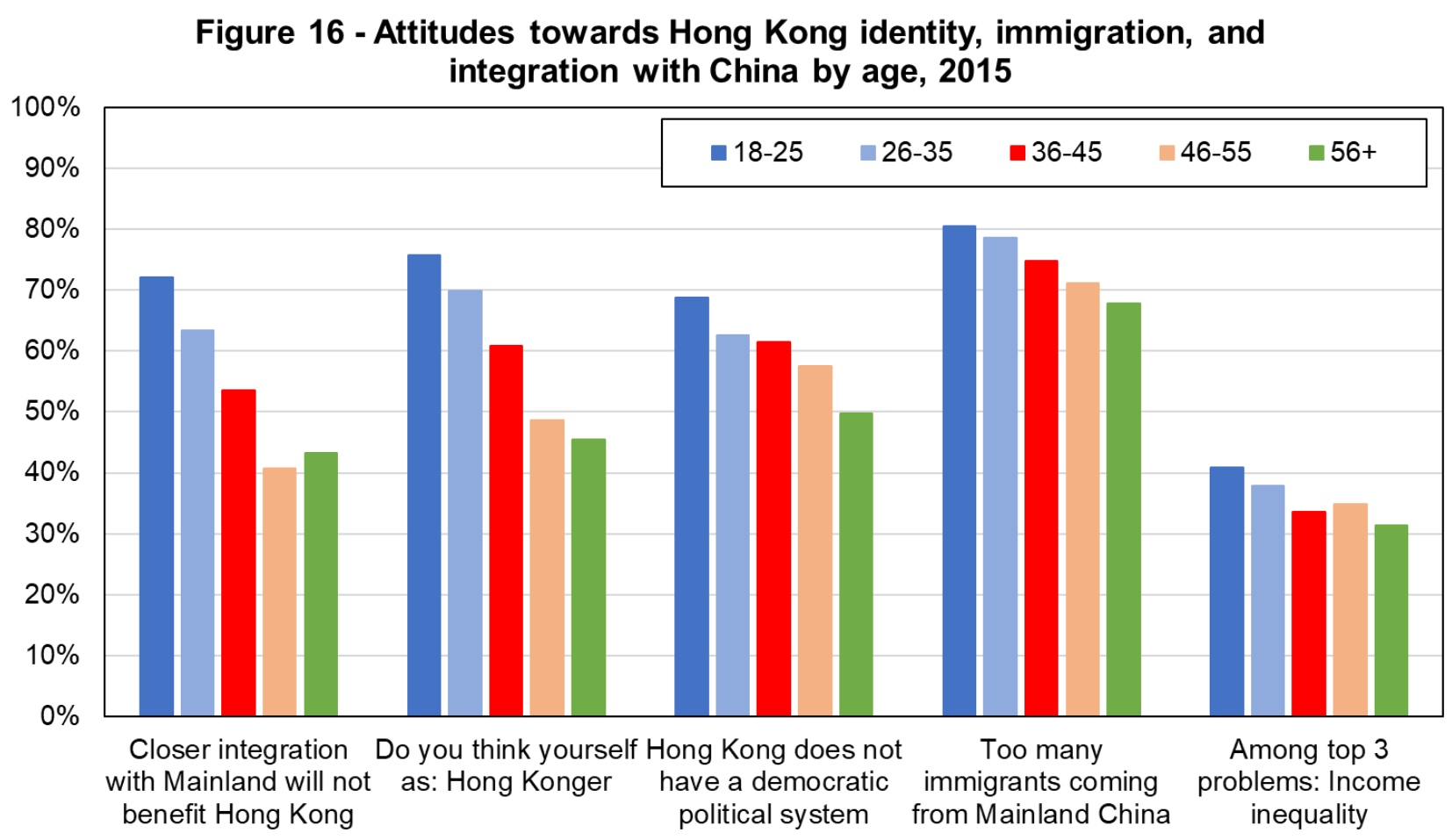

Source: authors' computations using the Hong Kong Election Study 2015.

Note: the figure shows the distribution of selected political attitudes by age in 2015.

These figures also suggest, however, that identity and political integration have been the key issues dividing generations. More than 70 percent of adults below 25 oppose integration with the mainland compared to 40 percent of those older than 55, and similar gaps separate generations when it comes to associations with "Hong Konger" identity. Disillusion with the democratic system ranks third in dividing generations, with a gap of about 20 percentage points between the older and younger cohorts. Opposition to immigration for the mainland also varies 
with age, but only some 10 percentage points separate the younger and older cohorts. Antiimmigration feelings appear in fact to be widespread, with more than 65 percent of respondents within each generation agreeing that immigration should be limited. Concerns about income disparities are also high, with about a third of respondents ranking inequality as one of the three most important problems in the city, but generational differences are moderate.

Political integration, cultural differentiation, and democratization seem to be the most important issues structuring political cleavages in Hong Kong. Attitudes towards these issues clearly differentiate generations, and they eventually translate into differences in electoral behaviors. It is important to stress, however, that this survey was conducted in 2015. Since then, and in particular since the 2019-2020 protests, support for the pro-democracy camp seems to have grown tremendously, which was visible in the results of the local elections of 2019, in which the pro-democrats achieved their biggest success in Hong Kong's history with 57 percent of votes and over 81 percent of seats. Such a landslide victory was possible in large part thanks to a surge in turnout among younger voters, which suggests that the generational cleavage is further deepening (Chung 2020). How recent events will transform the structure of political cleavages in Hong Kong yet remains to be determined.

\section{References}

C. H. Achen and T. Y. Wang, eds., The Taiwan Voter (University of Michigan Press, 2017).

C. H. Achen and T. Y. Wang, "Declining voter turnout in Taiwan: A generational effect?" Electoral Studies 58 (2019): 113-124.

M. Anderson and M. Klinthäll, "The Opening of the North-South Divide: Cumulative Causation, Household Income Disparity and the Regional Bonus in Taiwan 1976-2005," Structural Change and Economic Dynamics 23, no. 2 (2012): 170-179. 
E. L. G. Campbell, Uri nara, our nation: Unification, identity and the emergence of a new nationalism amongst South Korean young people (Australian National University, 2011).

I. T. Chen and D. Liao, “The Rise of the New Power Party in Taiwan's 2016 Legislative Election: Reality and Challenges," in Taiwan's Political Re-Alignment and Diplomatic Challenges, ed. W. Lee (Palgrave Macmillan, 2019).

Y. Chen and M. M. Szeto, “The Forgotten Road of Progressive Localism: New Preservation Movement in Hong Kong,” Inter-Asia Cultural Studies 16, no. 3 (2015): 436-453.

M. Chiang and B. Gerbier, "Cross-Strait Economic Relations: Recent Development and Implications for Taiwan," Revue de la Régulation 13 (2013): 1-18.

S. H. Choe "His Predecessors Failed. Can Moon Jae-in Make Peace With North Korea", The New York Times, May 3, 2018, https://www.nytimes.com/2018/05/03/world/asia/north-koreamoon-trump-kim.html (accessed June 15, 2020).

C. Y. C. Chu, “Top Incomes in Taiwan, 1977-2013” (WID.world Working Paper 2015).

Y. Chu and J. Lin, "Political Development in 20th-Century Taiwan: State-Building, Regime Transformation and the Construction of National Identity," The China Quarterly 165 (2001): $102-129$.

K. Chung, "Hong Kong District Council Election Data Reveals Turnout Now Highest Among Young People, Driven to The Ballot Box by Anti-Government Protests," South China Morning Post, April 4 2020, accessed May 31 2020, https://www.scmp.com/news/hong-kong/politics/ article/3078401/hong-kong-district-council-election-data-reveals-turnout.

L. Cooper and W. Lam, "Introduction," in Citizenship, Identity and Social Movements in the New Hong Kong, ed. W. Lam and L. Cooper (Routledge Contemporary China Series, 2018), $1-12$. 
S. Denyer and M. J. Kim, “Another former South Korea president jailed for corruption,” The Washington Post, October 5, 2018, https://www.washingtonpost.com/world/asia_pacific/ another-former-south-korea-president-jailed-for-corruption/2018/10/05/7e216cc6-c866-11e89158-09630a6d8725_story.html.

J. F. Downes, "Mainland Chinese Immigration in Hong Kong: Analysing Anti-Immigrant Sentiment," in Citizenship, Identity and Social Movements in the New Hong Kong, ed. W. Lam and L. Cooper (Routledge Contemporary China Series, 2018), 51-71.

The Economist Intelligence Unit, Democracy Index 2019 A Year of Democratic Setbacks and Popular Protest (The Economist, 2019).

A. L. Freedman, Political Change and Consolidation: Democracy's Rocky Road in Thailand, Indonesia, South Korea, and Malaysia (Palgrave Macmillan, 2006).

A. Gethin, "Extreme Inequality and the Structure of Political Cleavages in South Africa, 19942019," (WID.world Working Paper 2020/13, 2020).

A. Gethin and T. Jenmana, "Democratization and the Construction of Class Cleavages in Indonesia, Malaysia, Thailand, and the Philippines, 1992-2019” (forthcoming).

A. Gethin, C. Martínez-Toledano, and T. Piketty, "Political Cleavages and Inequality: Evidence from Electoral Democracies, 1950-2018” (Preliminary results, 2019: http://piketty.pse.ens.fr/files/GethinMartinezPiketty2019Slides.pdf).

Y. Hao, "Converging Mainlander and Native Taiwanese, 1949-2012," Australian Economic History Review 57, no. 1 (2017): 84-107.

O. Hellmann, Political Parties and Electoral Strategy (Palgrave Macmillan UK, 2011).

J. F. Hsieh, “Salient Issues in Taiwan's Electoral Politics,” Electoral Studies 15, no. 2 (1996): 219-235. 
J. F. Hsieh, "Ethnicity, National Identity, and Domestic Politics in Taiwan," Journal of Asian and African Studies 40, no. 1-2 (2005): 13-28.

C. Huang, "Generation effects? Evolution of Independence-Unification Views in Taiwan, 1996-2016," Electoral Studies 58 (2019): 103-112.

C. T. Hung, "Income Inequality in Hong Kong and Singapore" (Paris School of Economics, 2018).

H. B. Im, "Globalization, Democracy and Social Polarization in South Korea" in Korea 's Quest for Economic Democratization, ed. Y. Kim (Palgrave Macmillan, 2018).

J. Jao and M. McKeever, "Ethnic Inequalities and Educational Attainment in Taiwan," Sociology of Education 79, no. 2 (2006): 131-152.

K. Jiyoon, K. Kim, and K. Chungku, "South Korean Youths' Perceptions of North Korea and Unification" (Asan institute issue brief 2018-03, 2018).

M. P. Kaeding, "The Rise of 'Localism' in Hong Kong," Journal of Democracy 28, no. 1 (2017): 157-171.

W. J. Kang, "Income and Voting Behavior in Korean Politics: Why Do the Poor Support Conservative Political Parties?," Journal of International and Area Studies 24, n. 20 (2017): $15-33$.

H. Keum and J. R. Campbell, "Perils of Transition: Korea and Taiwan Democratization Compared," The Korean Journal of International Studies 16, no. 1 (2018): 29-55.

S. H. Kil and C. Moon, "Introduction: Understanding Korean Politics," in Understanding Korean Politics: An Introduction, S. H. Kil and C. Moon, eds. (State University of New York Press, 2001). 
H. M. Kim, J. Y. Choi, and J. Cho, "Changing Cleavage Structures in New Democracies: An Empirical Analysis of Regionalism in Korea," Electoral Studies 27, no. 1 (2008): 136-150.

N. N. Kim, “Top Incomes in Korea: Update, 1933-2016” (WID.world Working Paper 2018/13, 2018).

W. Kim, "Does Class Matter? Social Cleavages in South Korea's Electoral Politics in the Era of Neoliberalism.” Review of Political Economy 22, no. 4 (2010): 589-616.

Y. Kim and S. Park. "Emerging Cleavages in Korean Society: Region, Generation, Ideology, and Class." in Korea's Quest for Economic Democratization, ed. Y. Kim (Palgrave Macmillan, 2018).

Y. Kim, "Hell Joseon: Polarization and Social Contention in a Neo-liberal Age" in Korea's Quest for Economic Democratization, ed. Y. Kim (Palgrave Macmillan, 2018).

E. Kleefeld, "Hundreds of Thousands Attend Protest in Hong Kong over Extradition Bill," Vox, June 9 2019, accessed May 31 2020, https://www.vox.com/world/2019/6/9/18658650/hongkong-protest-march-china-extradition-bill-2019.

B. C. Koh, "The Foreign and Unification Policies of the Republic of Korea," in Understanding Korean Politics: An Introduction, S. H. Kil and C. Moon, eds. (State University of New York Press, 2001).

S. Lau, From Traditional Familism to Utilitarianistic Familism: The Metamorphosis of Familial Ethos Among the Hong Kong Chinese (Chinese University of Hong Kong, 1978).

Y. Lee and J. S. You, “Is Class Voting Emergent in Korea?," Journal of East Asian Studies 19, no. 2 (2019): 197-213.

S. Leung, "The 'China Factor' in the 1991 Legislative Council Election: The June 4th Incident and Anti-Communist China Syndrome," in Hong Kong Tried Democracy: The 1991 Elections 
in Hong Kong. Hong Kong: Hong Kong Institute of Asia-Pacific Studies, ed. L. Siu-kai and L. Kin-shuen, (Chinese University of Hong Kong, 1993), 187-235.

S. Leung, "The 'China Factor' and Voters' Choice in the 1995 Legislative Council Election," in The 1995 Legislative Council Elections in Hong Kong, ed. K. Hsin-chi (Chinese University of Hong Kong, 1996), 201-244.

N. Ma, "Political Parties and Elections," in Contemporary Hong Kong Politics, ed. L. Waiman, P. Luen-tim Lui, W. Wong, and I. Holliday (Hong Kong University Press, 2007).

N. Ma, “The Rise of 'Anti-China' Sentiments in Hong Kong and the 2012 Legislative Council Elections," China Review 15, no. 1 (2015): 39-66.

N. Ma, “The China Factor in Hong Kong Elections: 1991 to 2016," China Perspective 3 (2017): $17-26$.

N. Ma, "From Political Acquiescence to Civil Disobedience: Hong Kong's Road to Civil Disobedience," in The Umbrella Movement: Civil Resistance and Contentious Space in Hong Kong, ed. N. Ma and E. W. Cheng (Amsterdam University Press, 2020), 27-50.

P. Mason, Why It's Kicking Off Everywhere: The New Global Revolutions (Verso, 2012).

OECD, Pensions at a Glance 2015: OECD and G20 indicators (OECD Publishing, 2015).

OECD, "Poverty rates", OECD.org, https://data.oecd.org/inequality/poverty-rate.htm (accessed on June 15, 2020).

OECD, "Population with tertiary education", OECD.org, https://data.oecd.org/eduatt/ population-with-tertiary-education.htm (accessed on June 15, 2020). 
S. Ortmann, "The Development of Hong Kong Identity: From Local to National Identity," in Citizenship, Identity and Social Movements in the New Hong Kong, ed. W. Lam and L. Cooper (Routledge Contemporary China Series, 2018), 114-131.

R. Pacheco Pardo, "Moon on a Mission: South Korea's New Approach to the North," The Diplomat, March 14, 2018, https://thediplomat.com/2018/03/moon-on-a-mission-southkoreas-new-approach-to-the-north/ (accessed June 15, 2020).

L. Pang-kwong, "Comparative Study of Electoral Systems Module 5: Macro Report" (Comparative Study of Electoral Systems Module 5, 2016), https://cses.org/datacenter/ module5/macro/HKG_2016_Macro.pdf.

T. Piketty, "Brahmin Left vs Merchant Right: Rising Inequality \& the Changing Structure of Political Conflict (Evidence from France, Britain and the US, 1948-2017)" (WID.world Working Paper Series 2018/7, 2018).

S. Sheng and H. Liao, "Issues, Political Cleavages, and Party Competition in Taiwan," in The Taiwan Voter, ed. C. H. Achen and T. Y. Wang (University of Michigan Press, 2017).

M. Sing, "Mass Support for the Umbrella Movement," in The Umbrella Movement: Civil Resistance and Contentious Space in Hong Kong, ed. N. Ma and E. W. Cheng (Amsterdam University Press, 2020), 233-250.

J. Stiglitz and B. Pleskovic, "Annual World Bank Conference on Development Economics 1997" (The World Bank, 1998).

A. C. Tan and K. Ho, "Cross-Strait Relations and the Taiwan Voter," in The Taiwan Voter, ed.

C. H. Achen and T. Y. Wang (University of Michigan Press, 2017).

S. Veg, "The Rise of 'Localism' and Civic Identity in Post-handover Hong Kong: Questioning the Chinese Nation-state," The China Quarterly 230 (2017): 323-347. 
A. H. Wang, "The Myth of Polarization Among Taiwanese Voters: The Missing Middle," Journal of East Asian Studies 19, no. 3 (2019): 275-287.

T. Y. Wang, "Changing Boundaries: The Development of the Taiwan Voters' Identity," in The Taiwan Voter, ed. C. H. Achen and T. Y. Wang (University of Michigan Press, 2017).

S. H. Wong, K. Lee, K. Ho, and H. D. Clarke, "Immigrant Influx and Generational Politics: A Comparative Case Study of Hong Kong and Taiwan,” Electoral Studies 58 (2019): 84-93.

S. H. Wong, N. Ma, and W. Lam, "Immigrants as Voters in Electoral Autocracies: The Case of Mainland Chinese Immigrants in Hong Kong," Journal of East Asian Studies 18, no. 1 (2018): 67-95.

H. Wong and K. M. Wan, "The Housing Boom and the Rise of Localism in Hong Kong: Evidence from the Legislative Council Election in 2016," China Perspectives 3 (2018): 31-40.

Y. Wu, "From Identity to Distribution: Paradigm Shift in Taiwan Politics: A First Cut" (Annual Conference of the American Association for Chinese Studies, 2013).

J. J. Yang, The Political Economy of the Small Welfare State in South Korea (Cambridge University Press, 2017).

C. Yu, "Parties, Partisans, and Independents in Taiwan," in The Taiwan Voter, ed. C. H. Achen and T. Y. Wang (University of Michigan Press, 2017). 


\section{Figure A1 - Legislative election results in South Korea,}

1985-2020

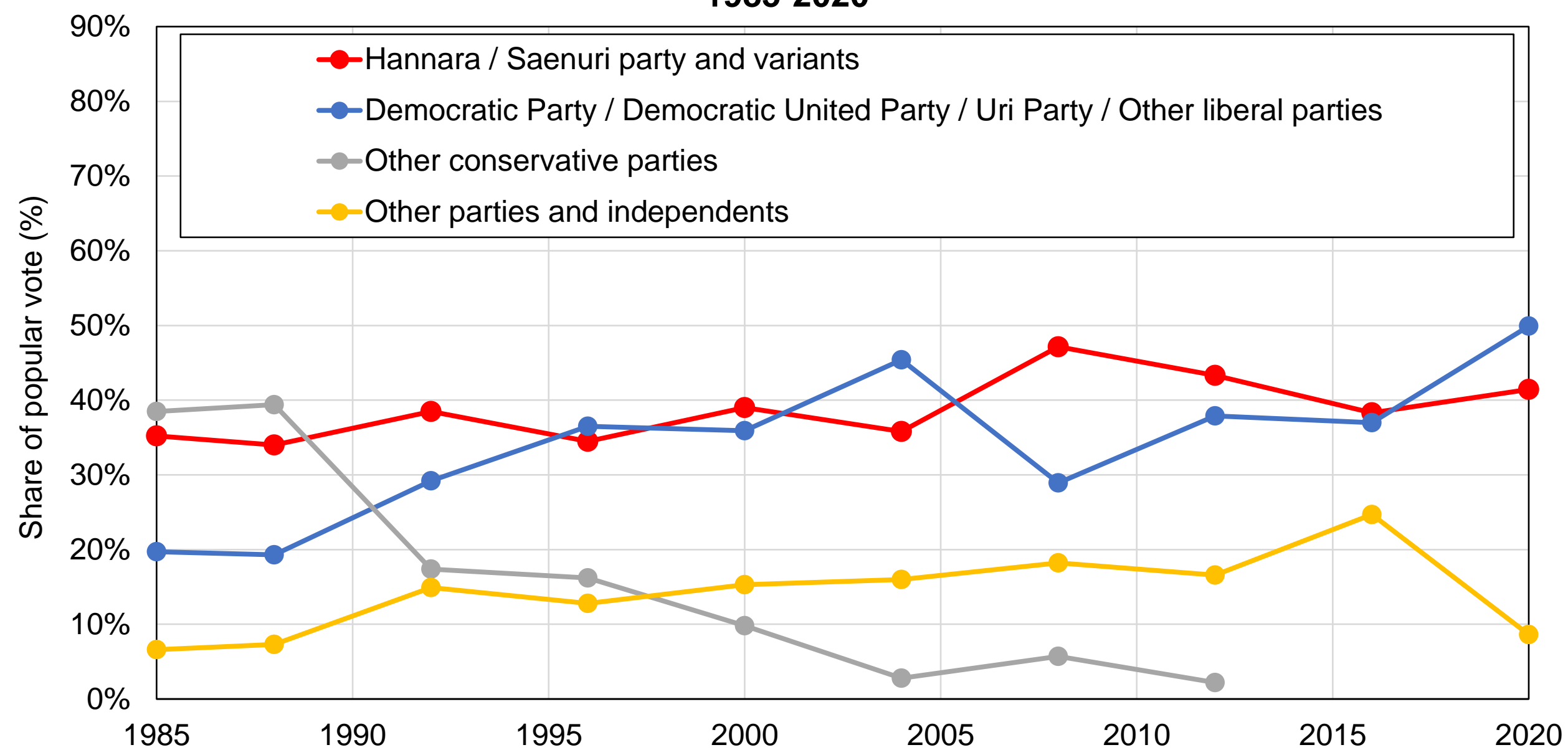

Source: authors' computations using official election results.

Note: the figure shows the share of votes received by selected groups of South Korean political parties in legislative elections between 1985 and 2020. Vote shares correspond to single-member constituencies. Variants to the Hannara party include the United Future, Saenuri, Democratic Justice, Democratic Liberal, New Korea, and Liberty Korea. 
Figure A2 - Vote for the Hannara / Saenuri Party by age group

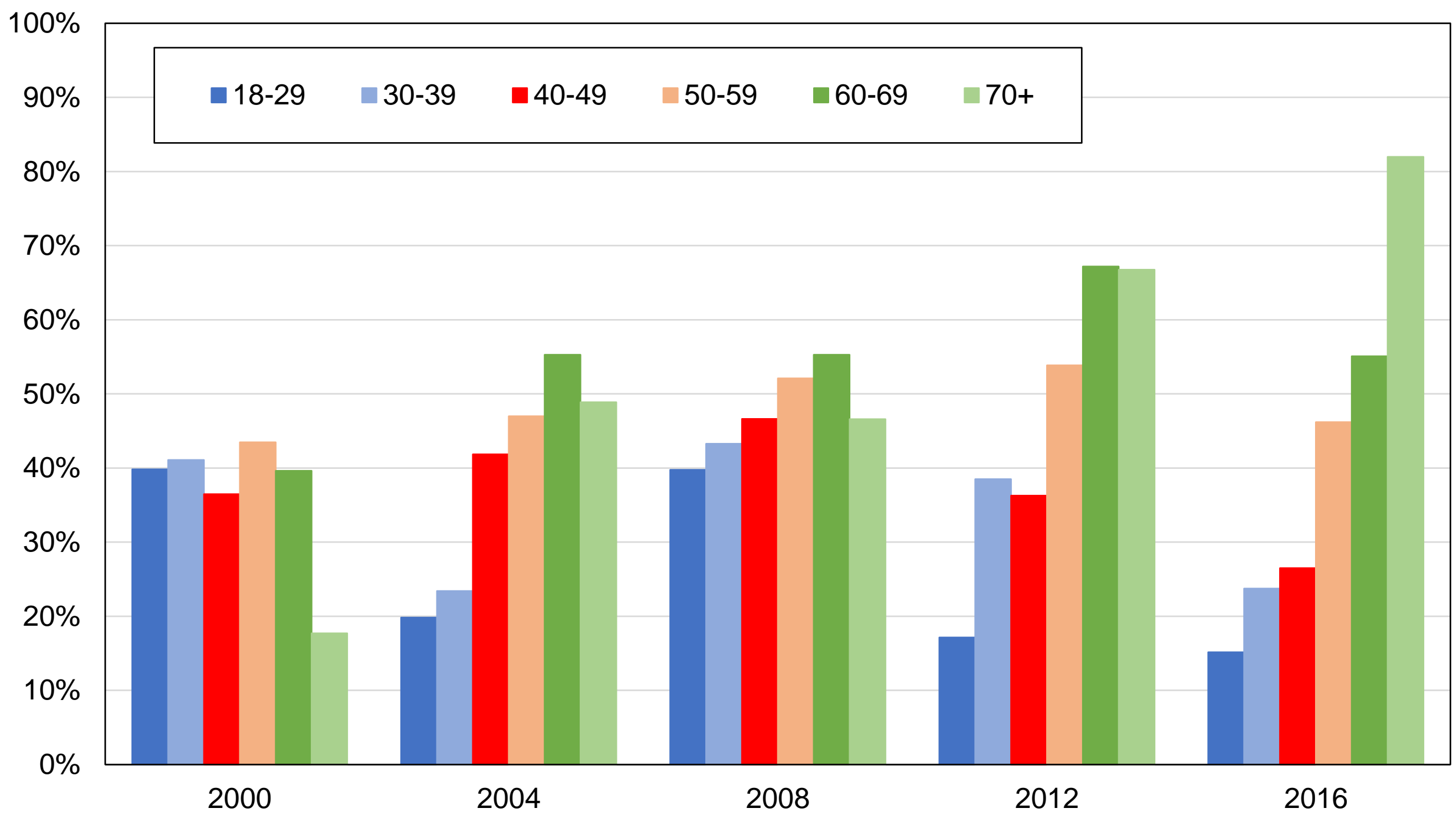

Source: authors' computations using South Korean political attitudes surveys.

Note: the figure shows the share of votes received by the Hannara / Saenuri Party by age group. 
Figure A3 - The regional cleavage in South Korea

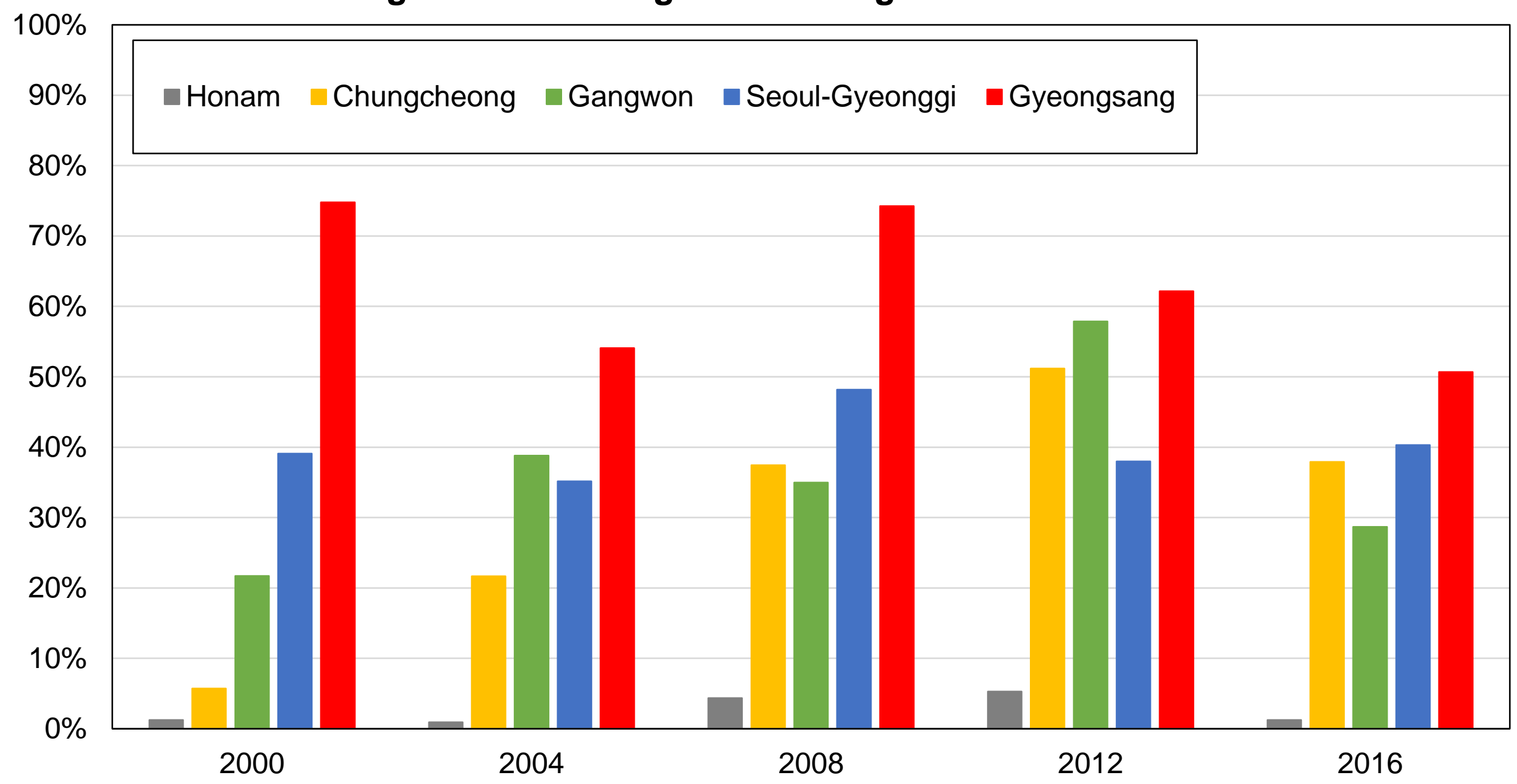

Source: authors' computations using South Korean political attitudes surveys.

Note: the figure shows the share of votes received by the Hannara / Saenuri Party by region. In 2016

Honam represented approximately $10 \%$ the electorate, Chungcheong 10\%, Gangwon 4\%, Seoul-

Gyeonggy 49\%, and Gyeongsang 26\%. 


\section{Figure A4 - Vote for the Hannara / Saenuri Party among university graduates}

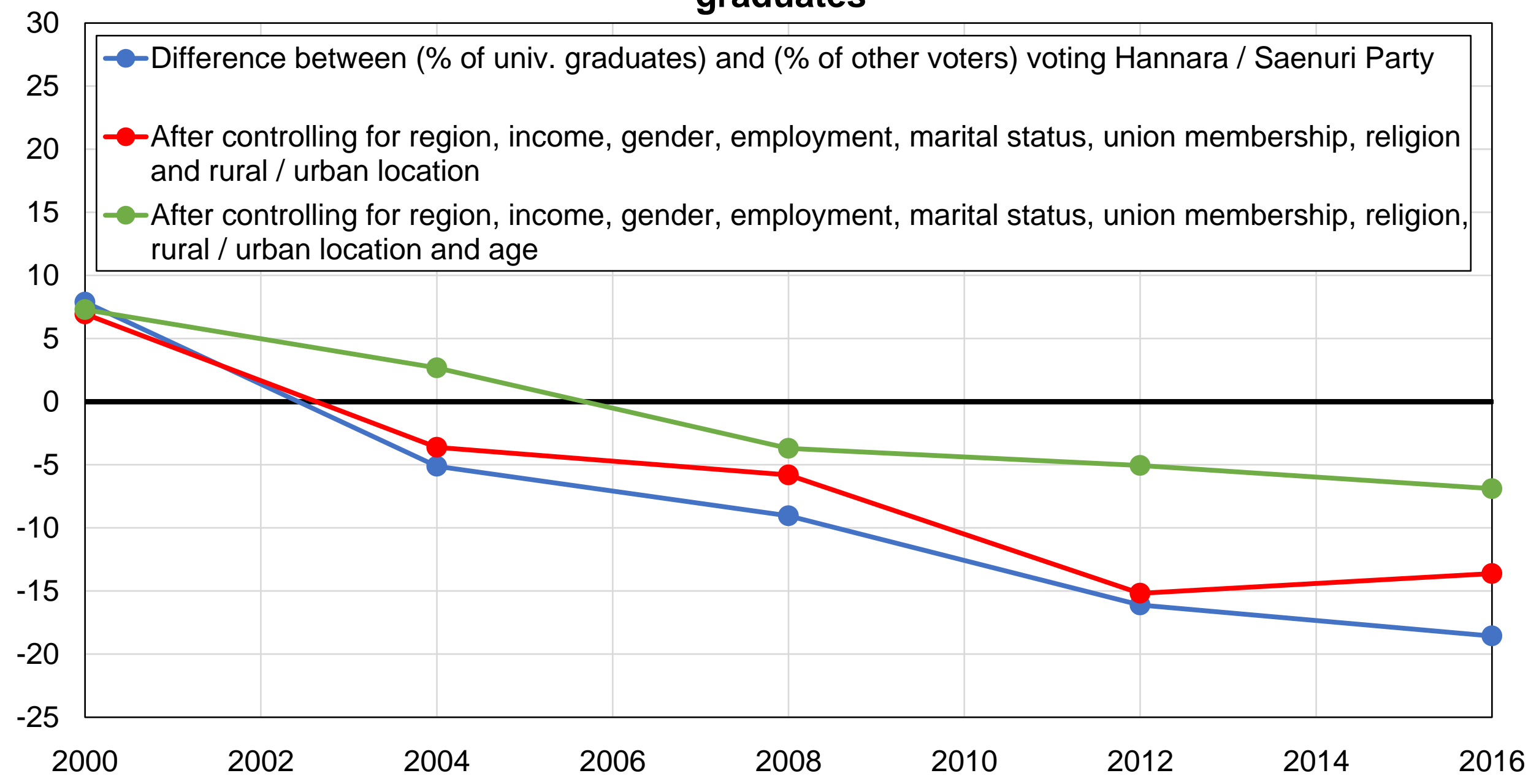

Source: authors' computations using South Korean political attitudes surveys.

Note: the figure shows the difference between the share of university graduates and the share of other voters voting for the Hannara / Saenuri Party, before and after controlling for other variables. 


\section{Figure A42 - Vote for the Hannara / Saenuri Party among low-income voters}

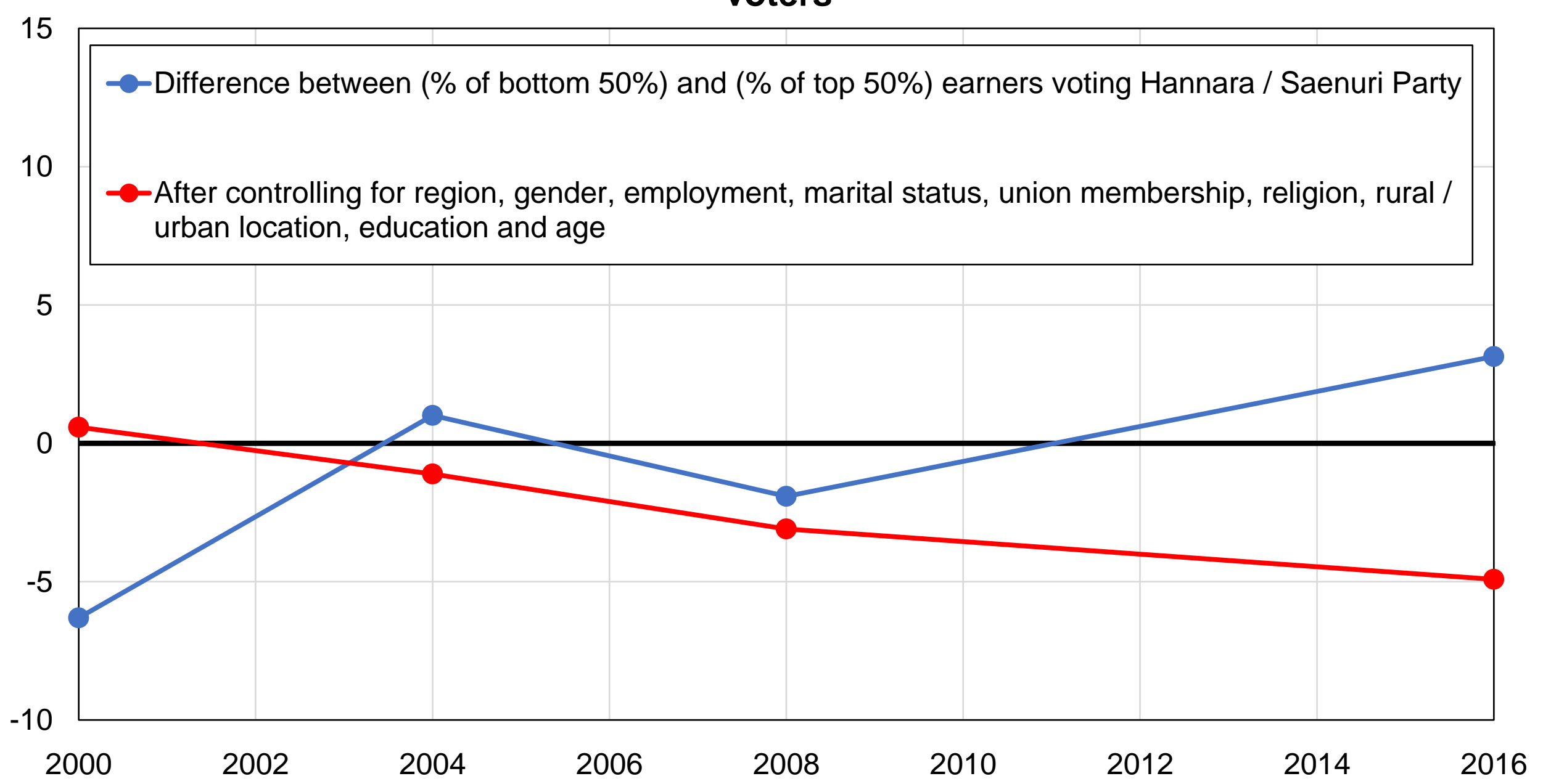

Source: authors' computations using South Korean political attitudes surveys.

Note: the figure shows the difference between the share of bottom $50 \%$ income voters and the share of top $50 \%$ income earners voting for the Hannara / Saenuri Party, before and after controlling for other variables. 
Figure A6 - Presidential election results in South Korea, 1987-2017

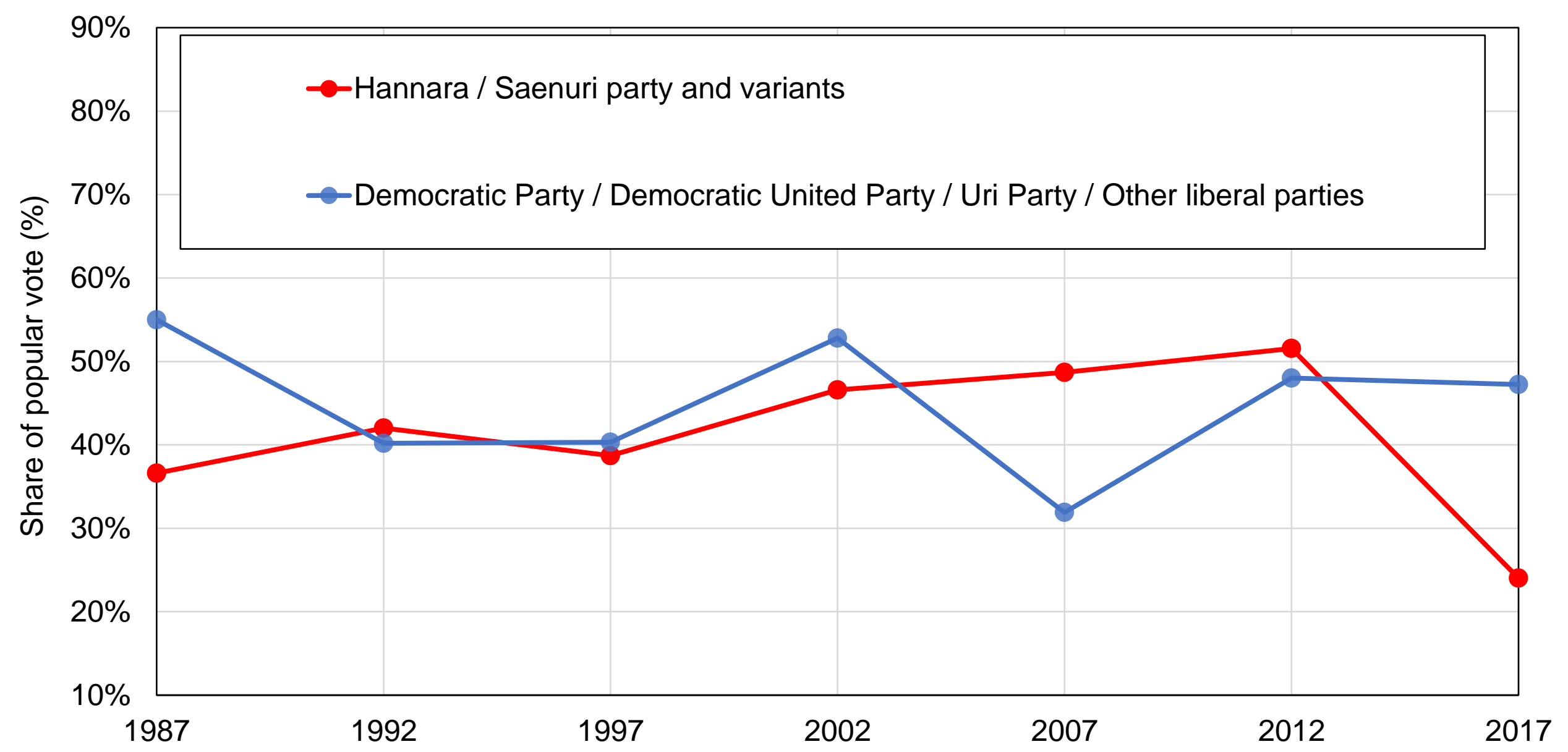

Source: authors' computations using official election results.

Note: the figure shows the share of votes received by selected groups of South Korean political parties in presidential elections between 1987 and 2017. Variants to the Hannara party include United Future, Saenuri, Democratic Justice, Democratic Liberal, New Korea, and Liberty Korea. 
Figure A7 - The composition of the electorate by education level

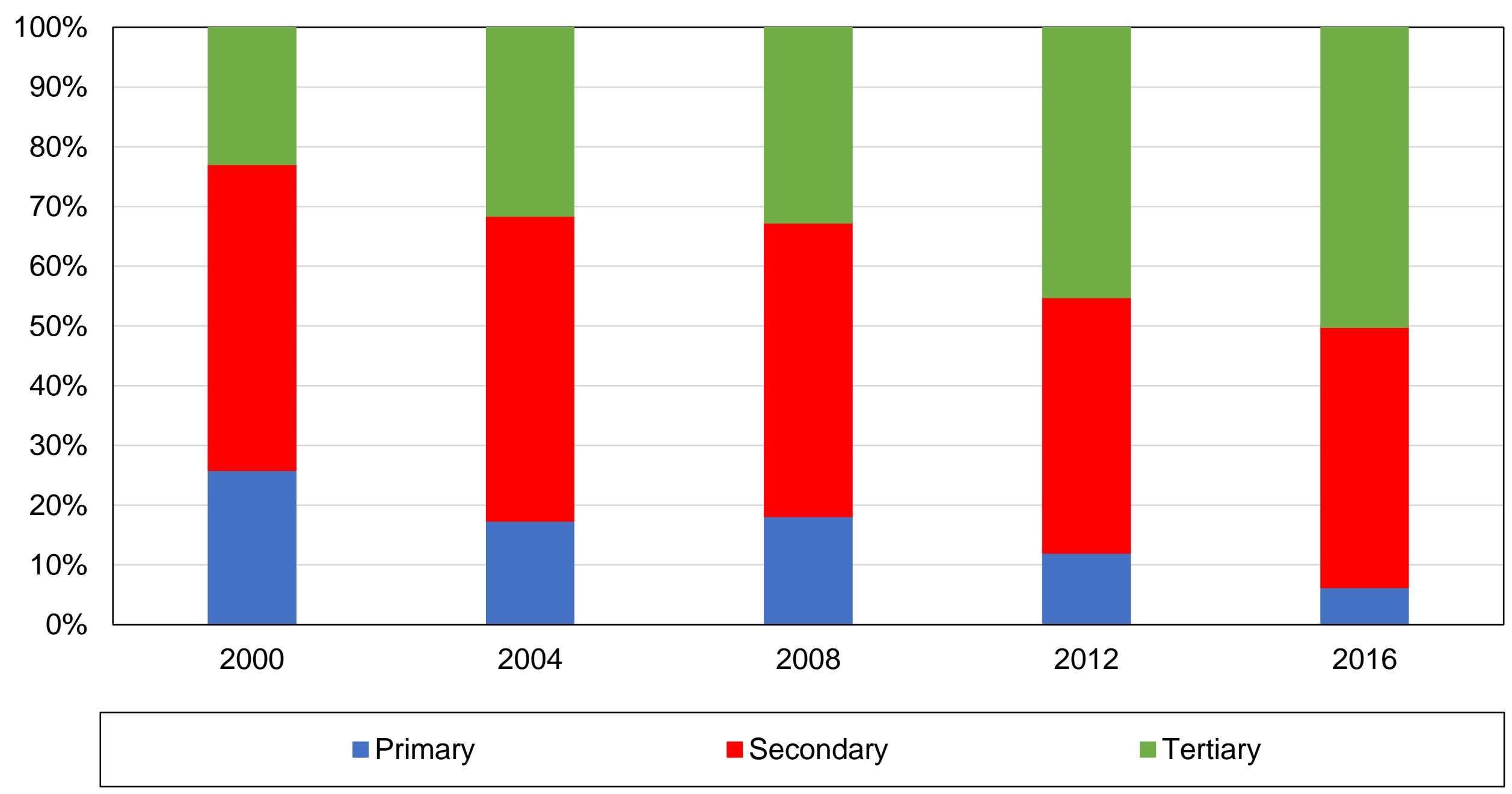

Source: authors' computations using South Korean political attitudes surveys. Note: the figure shows the composition of the electorate by education level. 
Figure A8 - The composition of the electorate by age group

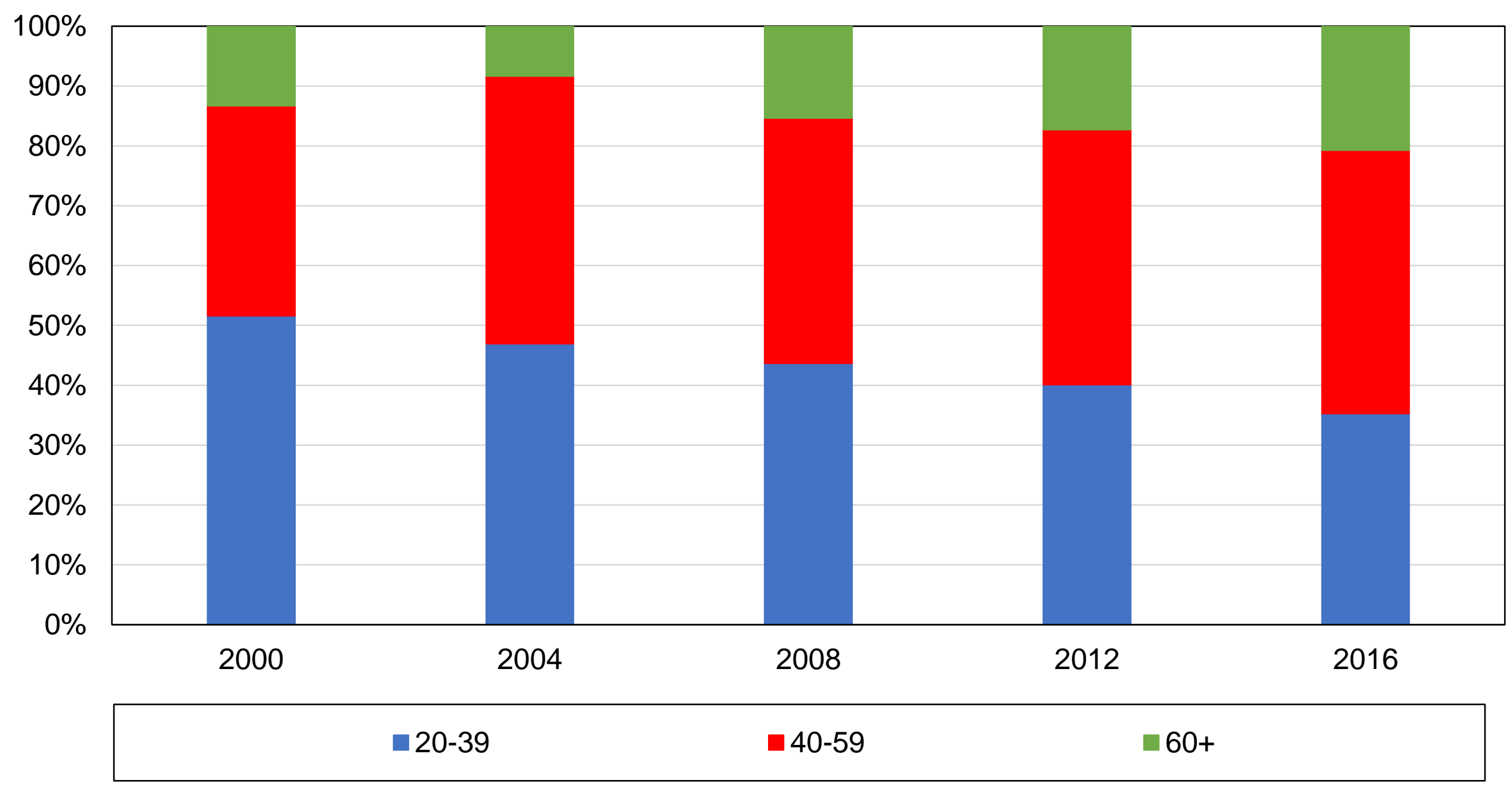

Source: authors' computations using South Korean political attitudes surveys. Note: the figure shows the composition of the electorate by age group. 
Figure A9 - The composition of the electorate by region

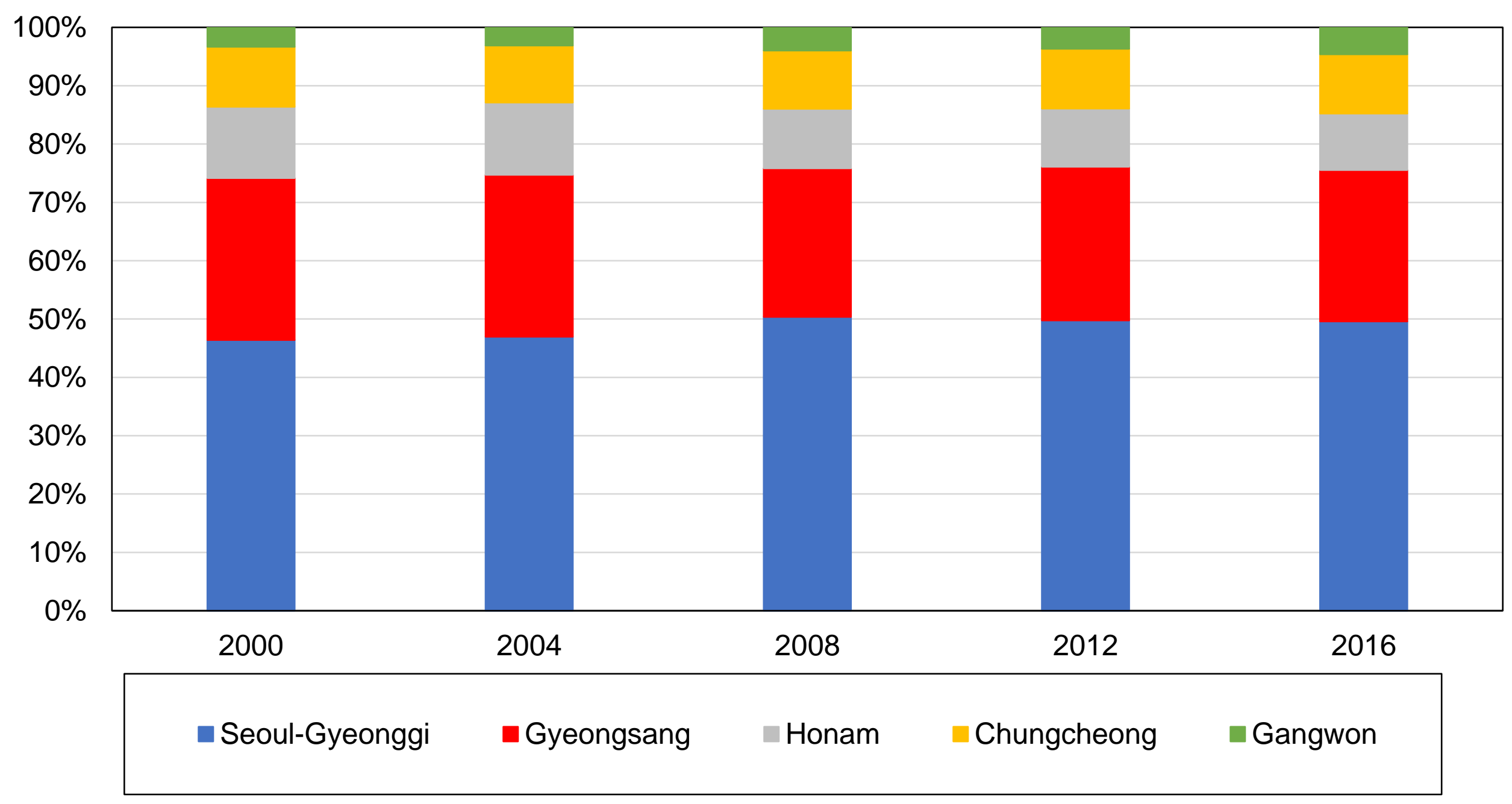

Source: authors' computations using South Korean political attitudes surveys. Note: the figure shows the composition of the electorate by region. 
Figure A10 - The composition of the electorate by religion

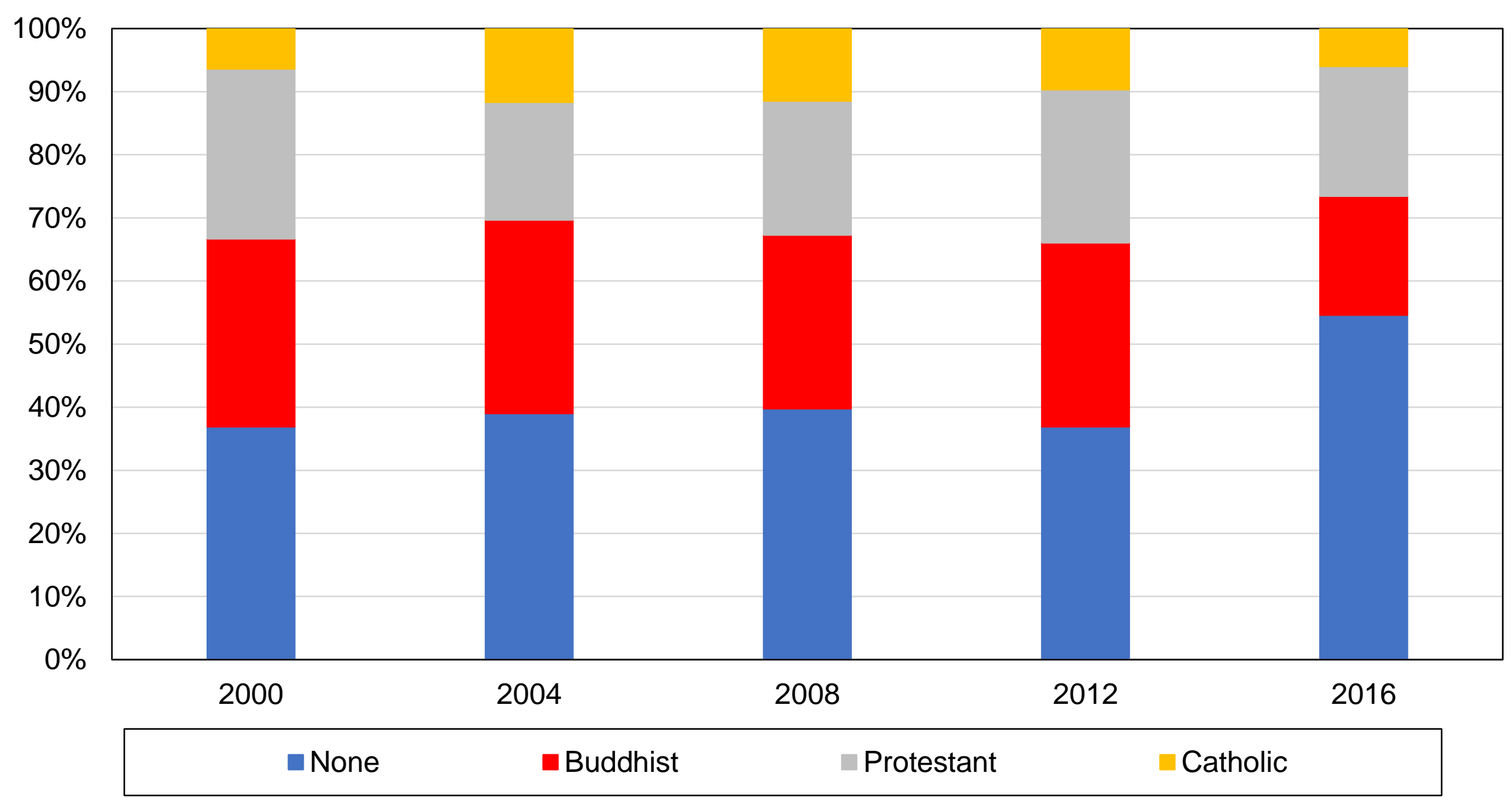

Source: authors' computations using South Korean political attitudes surveys. Note: the figure shows the composition of the electorate by religious affiliation. 
Figure A11 - Composition of regions by religion, 2000

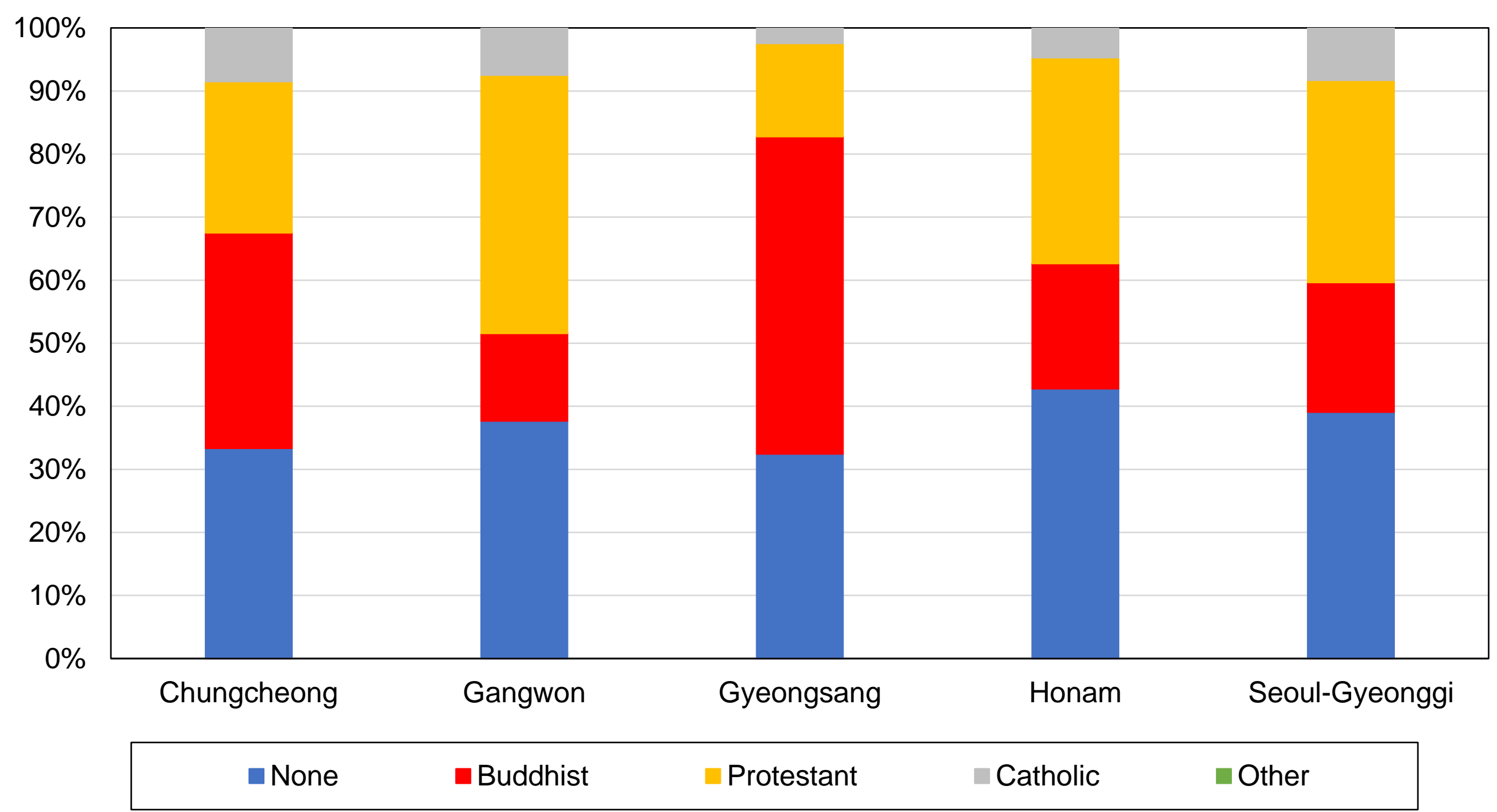

Source: authors' computations using South Korean political attitudes surveys.

Note: the figure shows composition of regions by religious affiliation in 2000 . 
Figure A12 - Composition of regions by religion, 2016

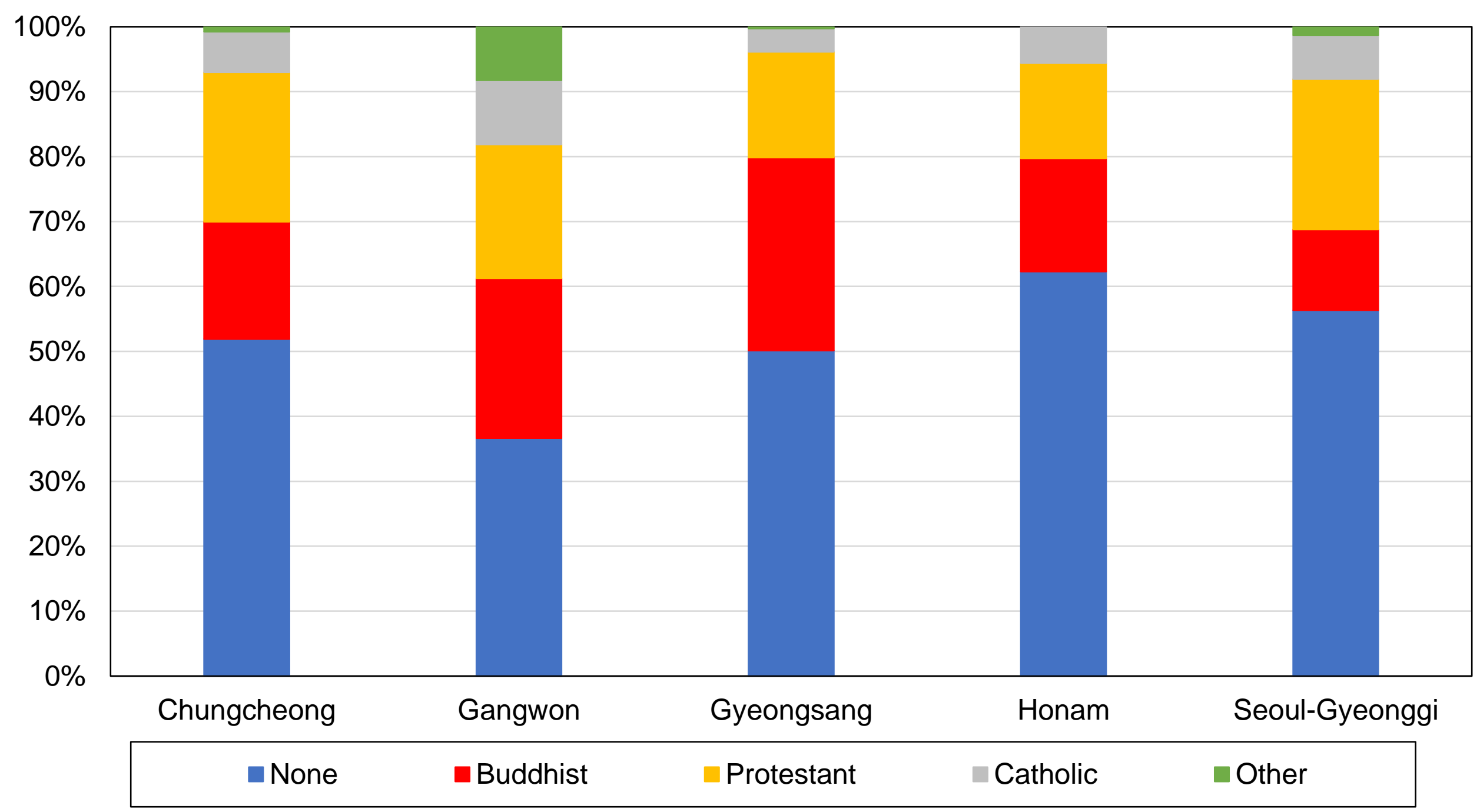

Source: authors' computations using South Korean political attitudes surveys.

Note: the figure shows the composition of regions by religious affiliation in 2016 . 
Figure A13 - Composition of regions by age group, 2000

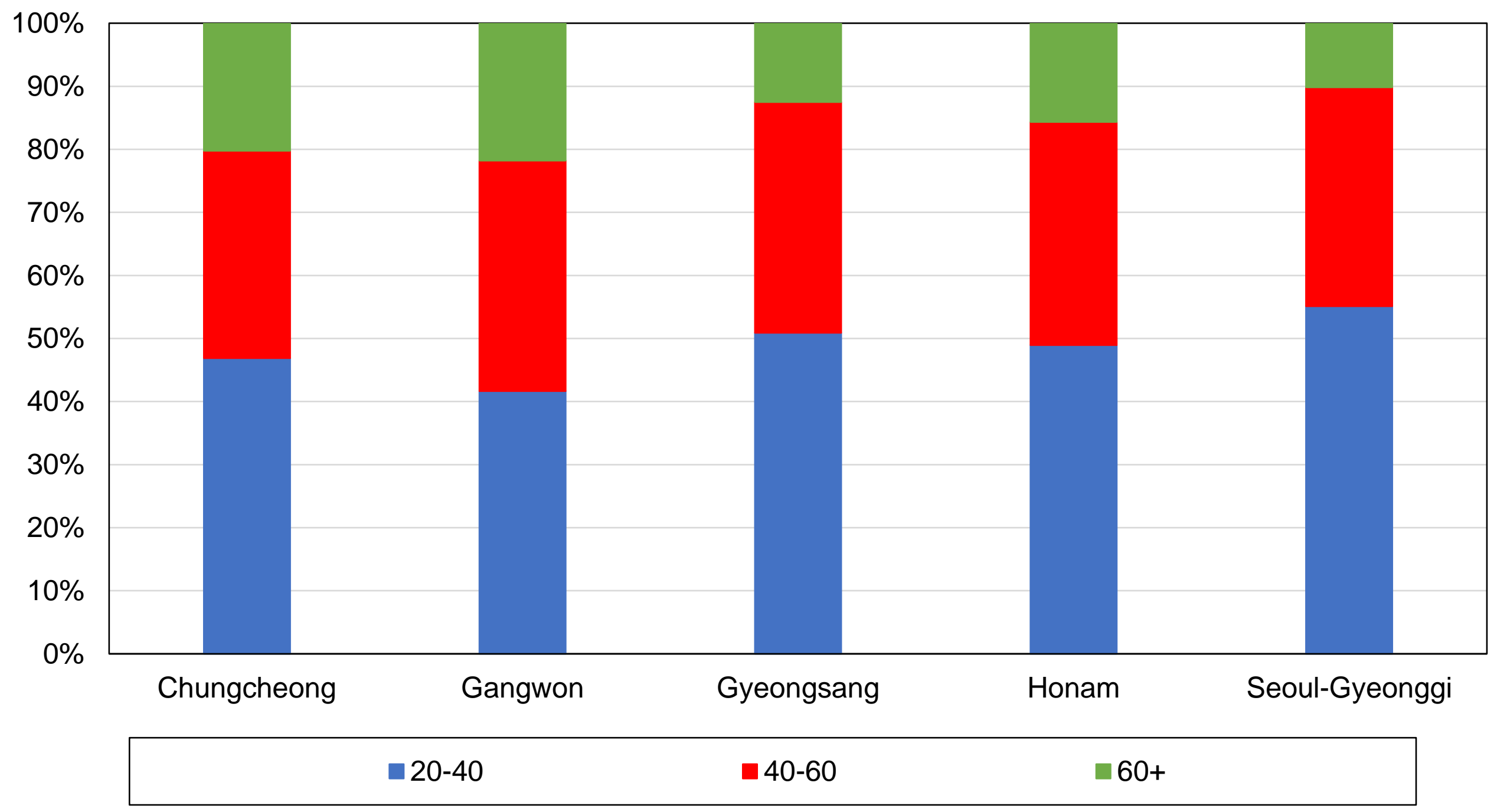

Source: authors' computations using South Korean political attitudes surveys.

Note: the figure shows the composition of regions by age group in 2000 . 
Figure A14 - Composition of regions by age group, 2016

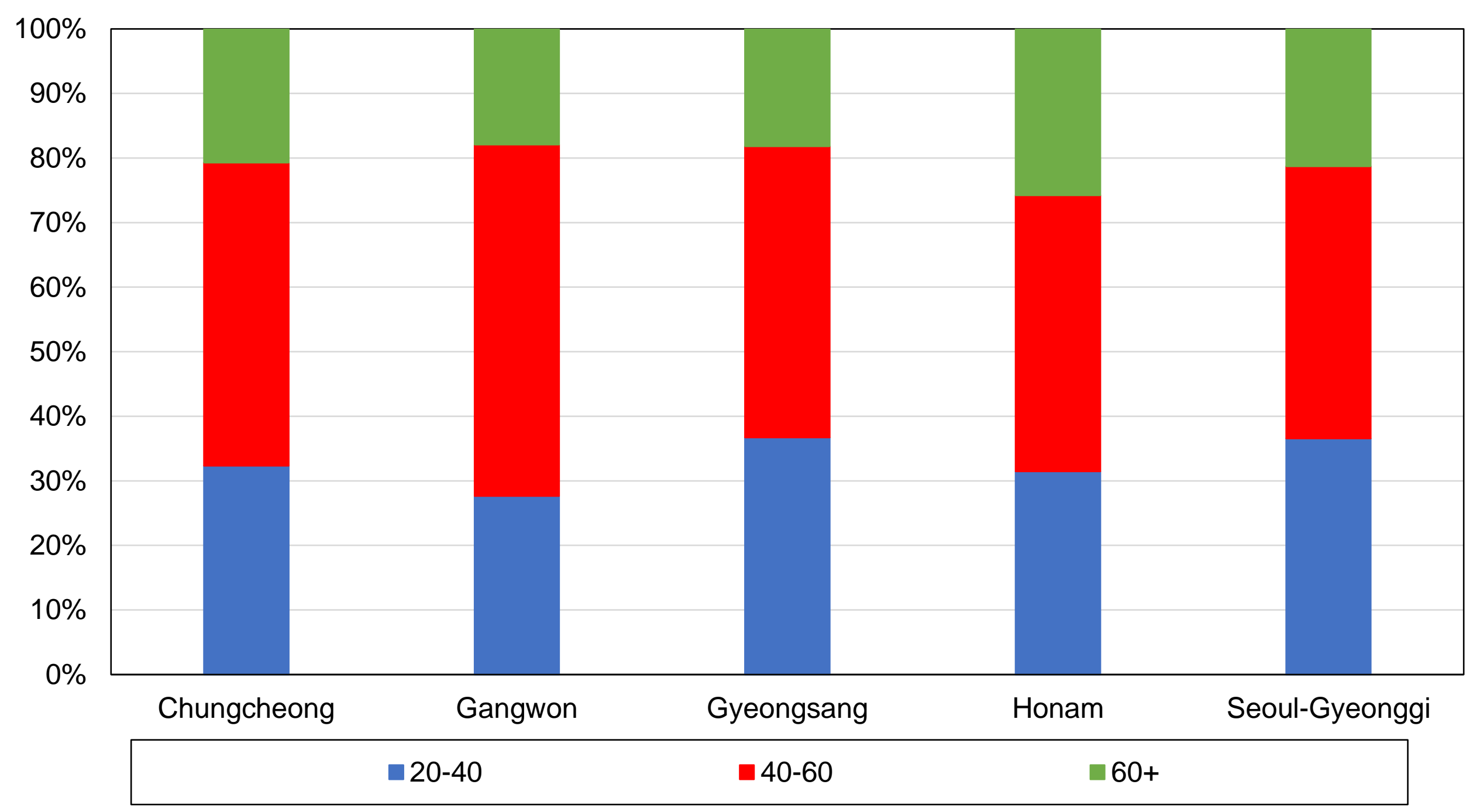

Source: authors' computations using South Korean political attitudes surveys.

Note: the figure shows the composition of regions by age group in 2016 . 
Figure A15 - Composition of income quintiles by education level, 2000

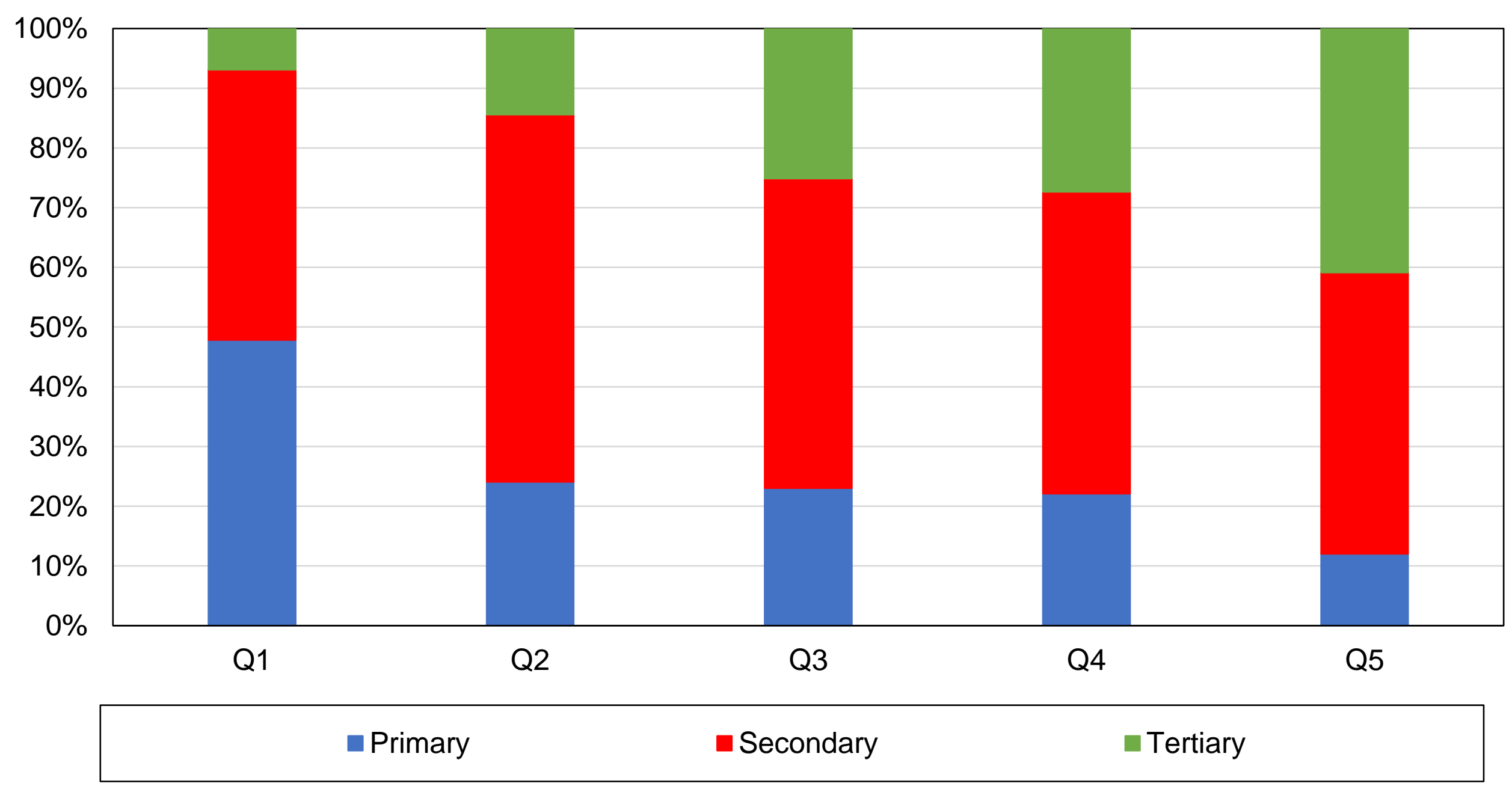

Source: authors' computations using South Korean political attitudes surveys.

Note: the figure shows the composition of income quintiles by education level in 2000 . 
Figure A16 - Composition of income quintiles by education level, 2016

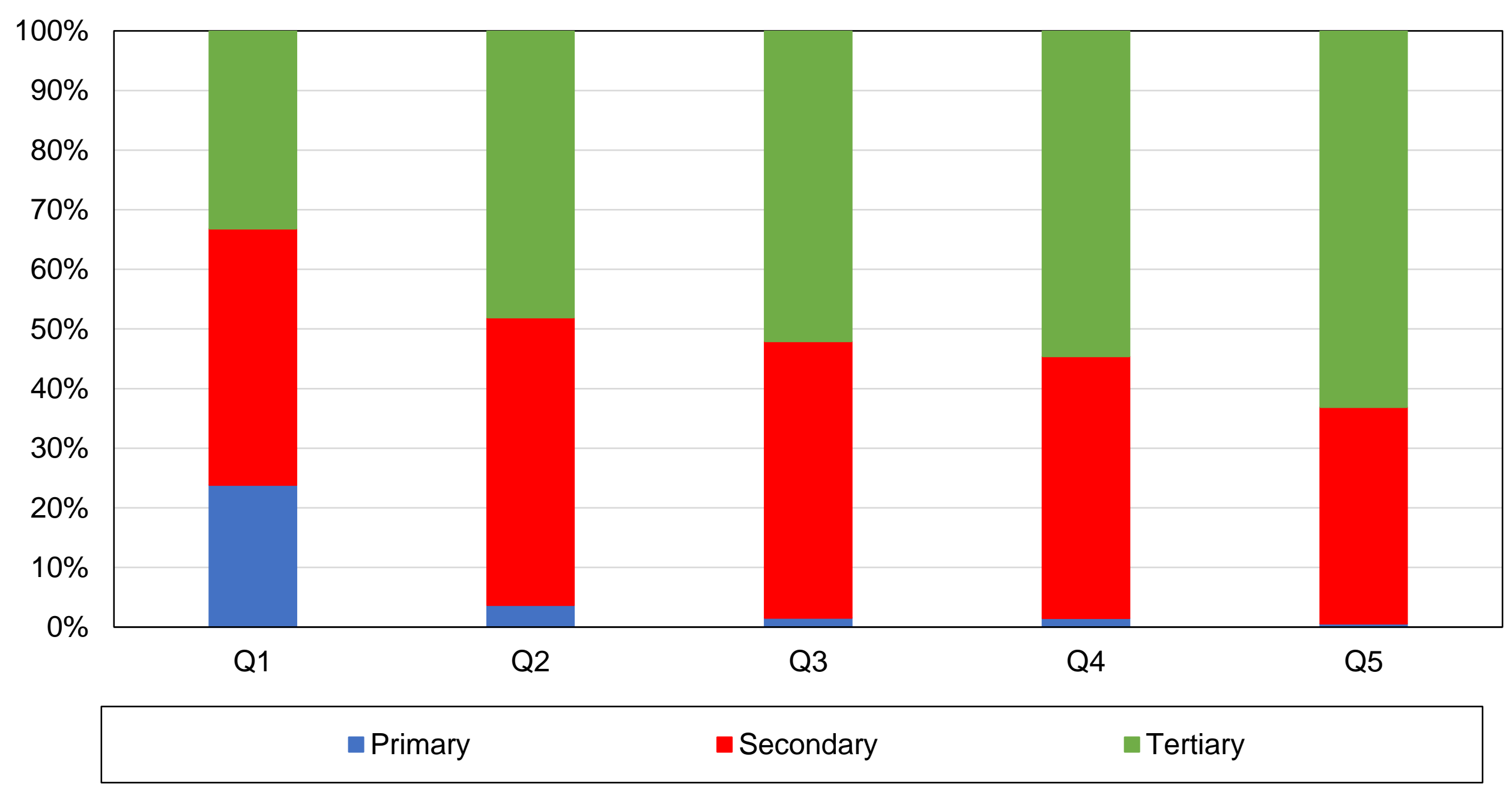

Source: authors' computations using South Korean political attitudes surveys.

Note: the figure shows the composition of income quintiles by education level in 2016. 
Figure A17 - Composition of income quintiles by age group, 2000

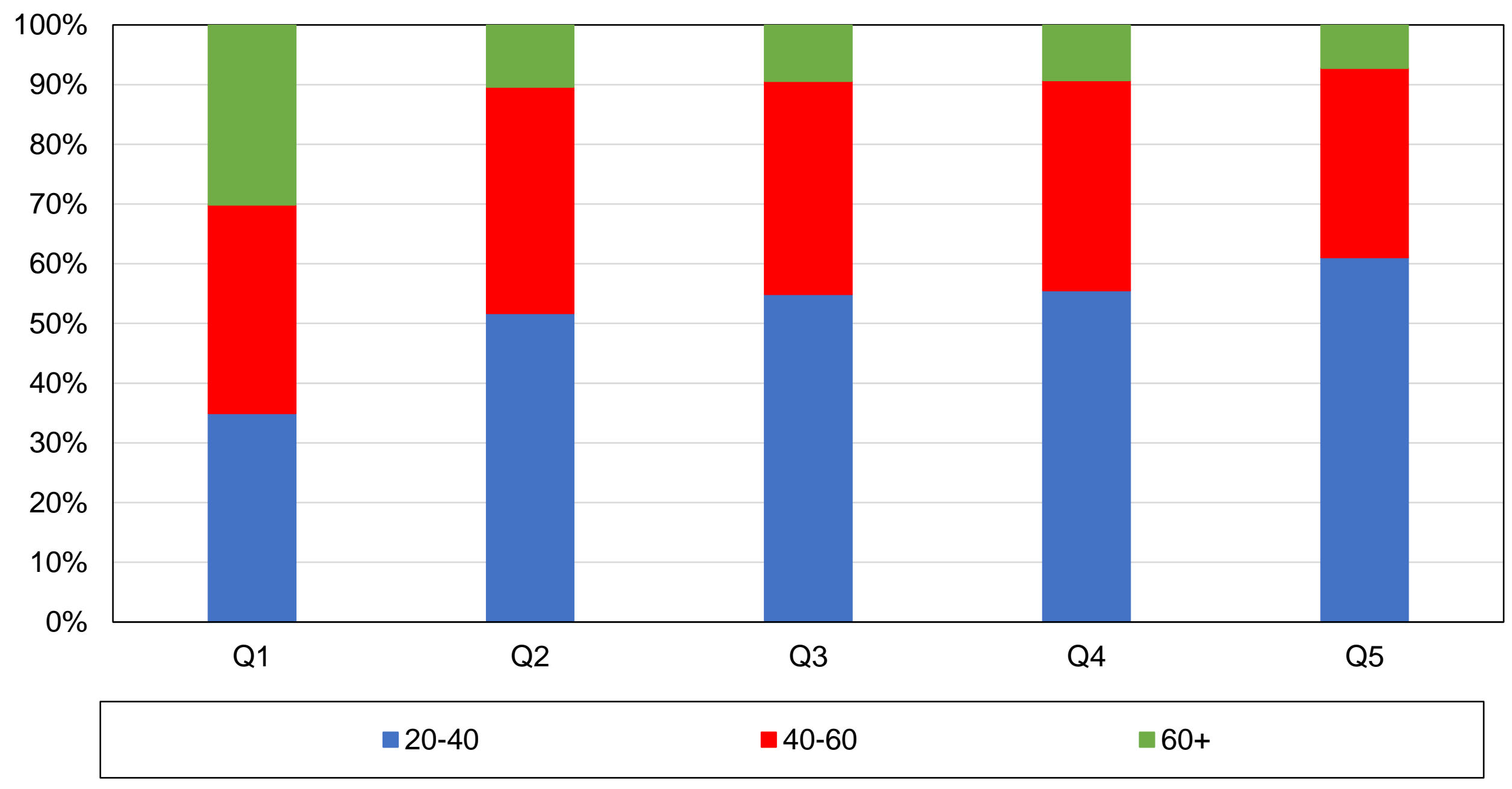

Source: authors' computations using South Korean political attitudes surveys.

Note: the figure shows the composition of income quintiles by age group in 2000 . 
Figure A18 - Composition of income quintiles by age group, 2016

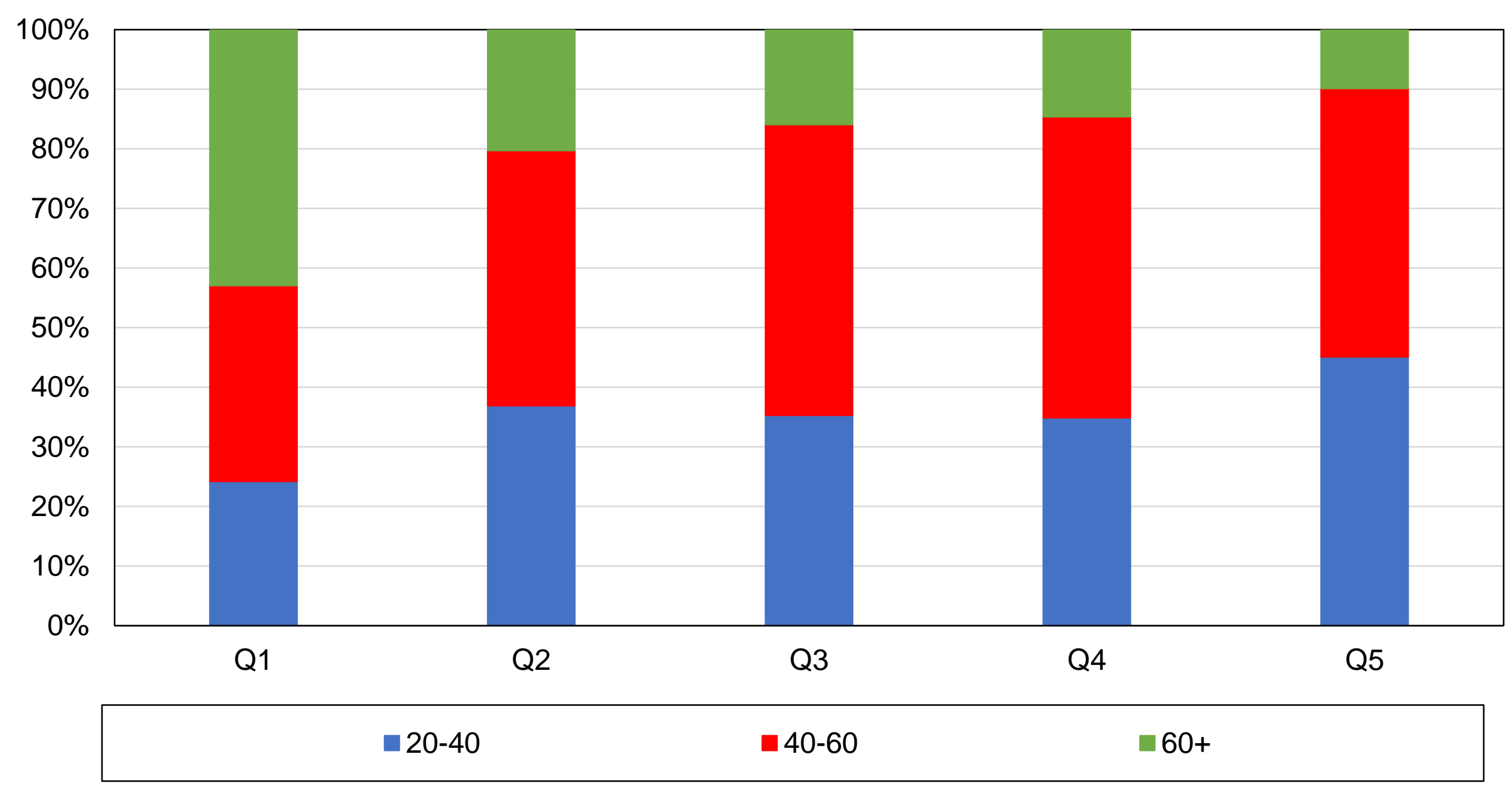

Source: authors' computations using South Korean political attitudes surveys.

Note: the figure shows the composition of income quintiles by age group in 2016 . 
Figure A19 - Composition of income quintiles by region, 2000

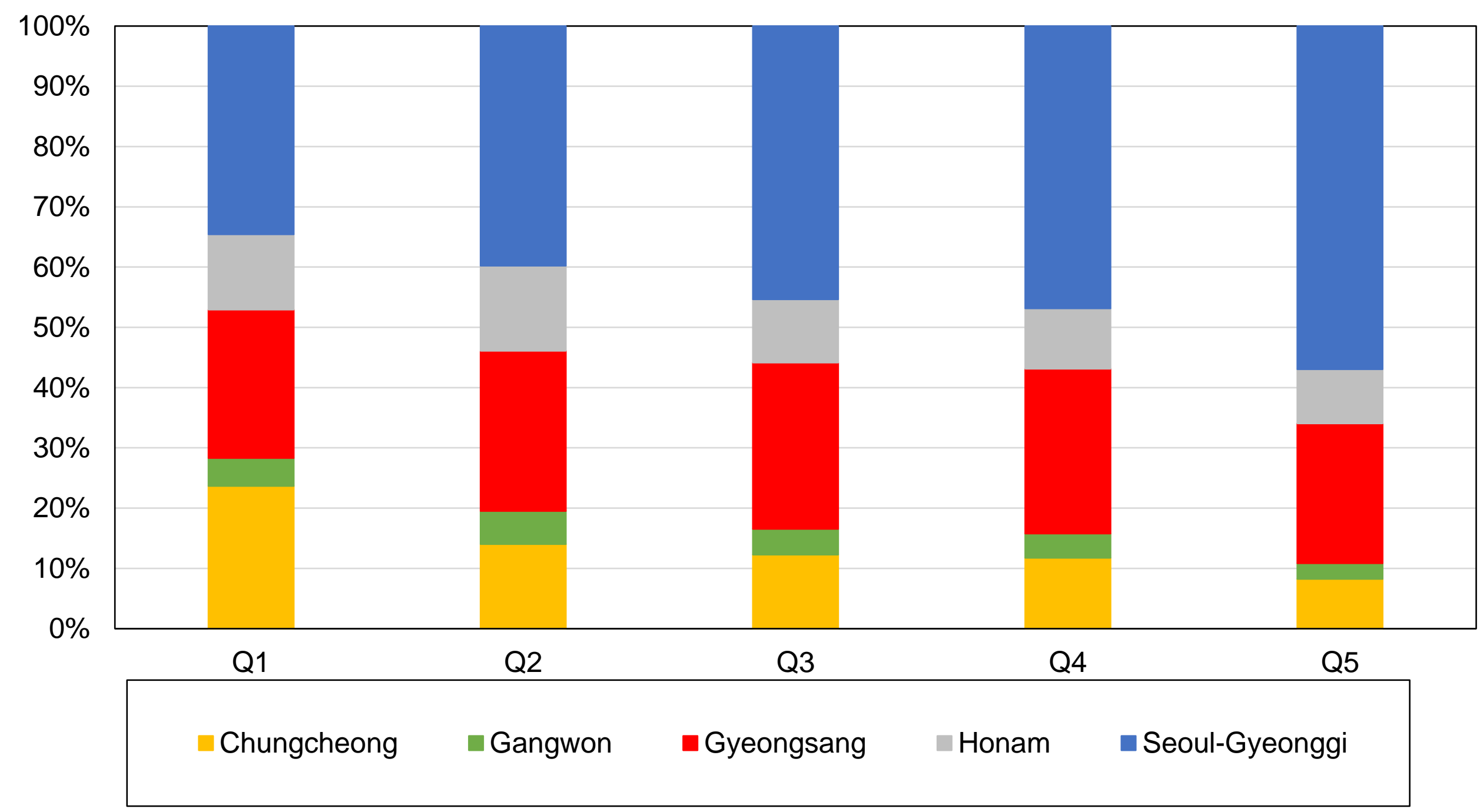

Source: authors' computations using South Korean political attitudes surveys.

Note: the figure shows the composition of income quintiles by region in 2000 . 
Figure A20 - Composition of income quintiles by region, 2016

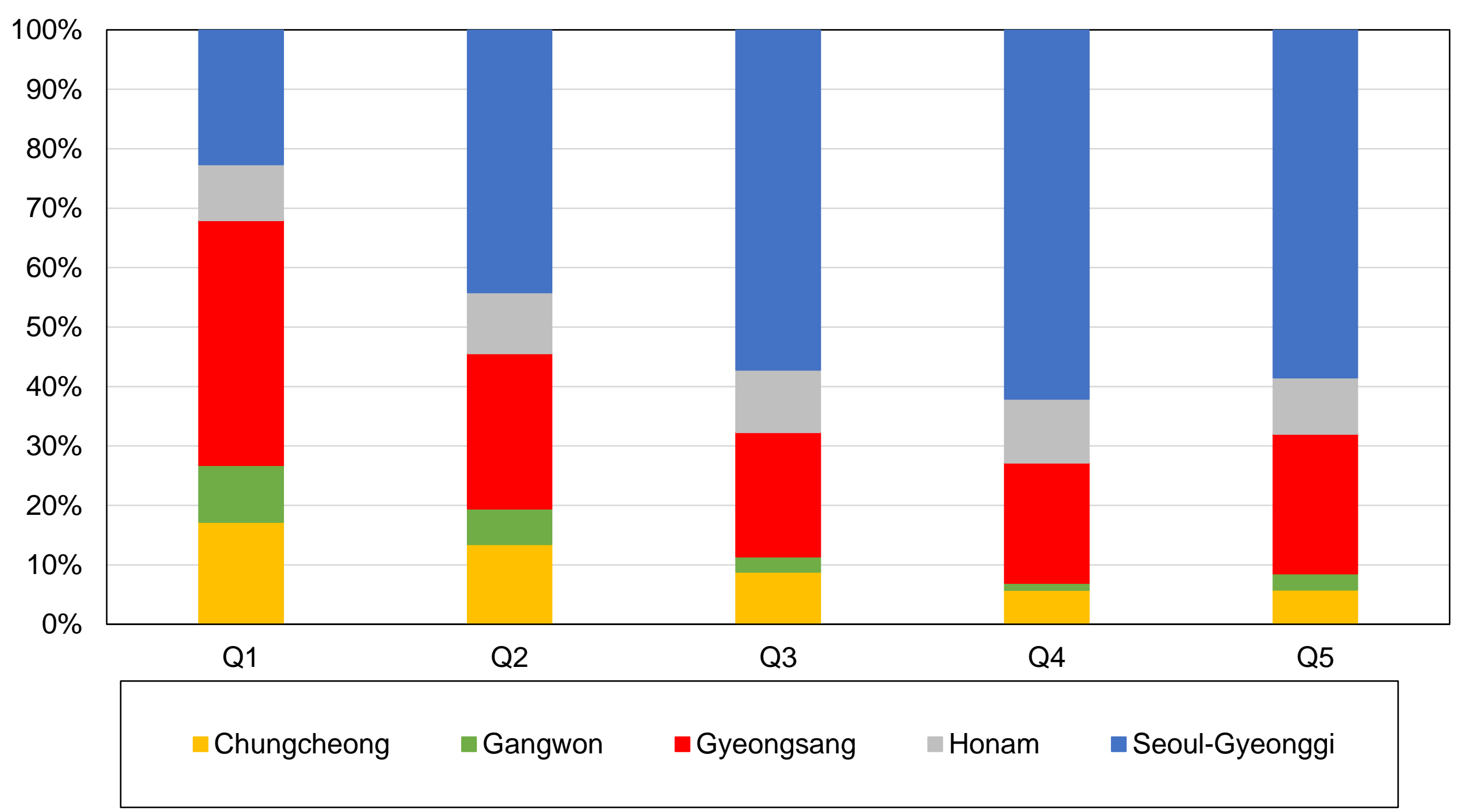

Source: authors' computations using South Korean political attitudes surveys. Note: the figure shows the composition of income quintiles by region in 2016 . 
Figure A21 - Composition of income quintiles by religion, 2000

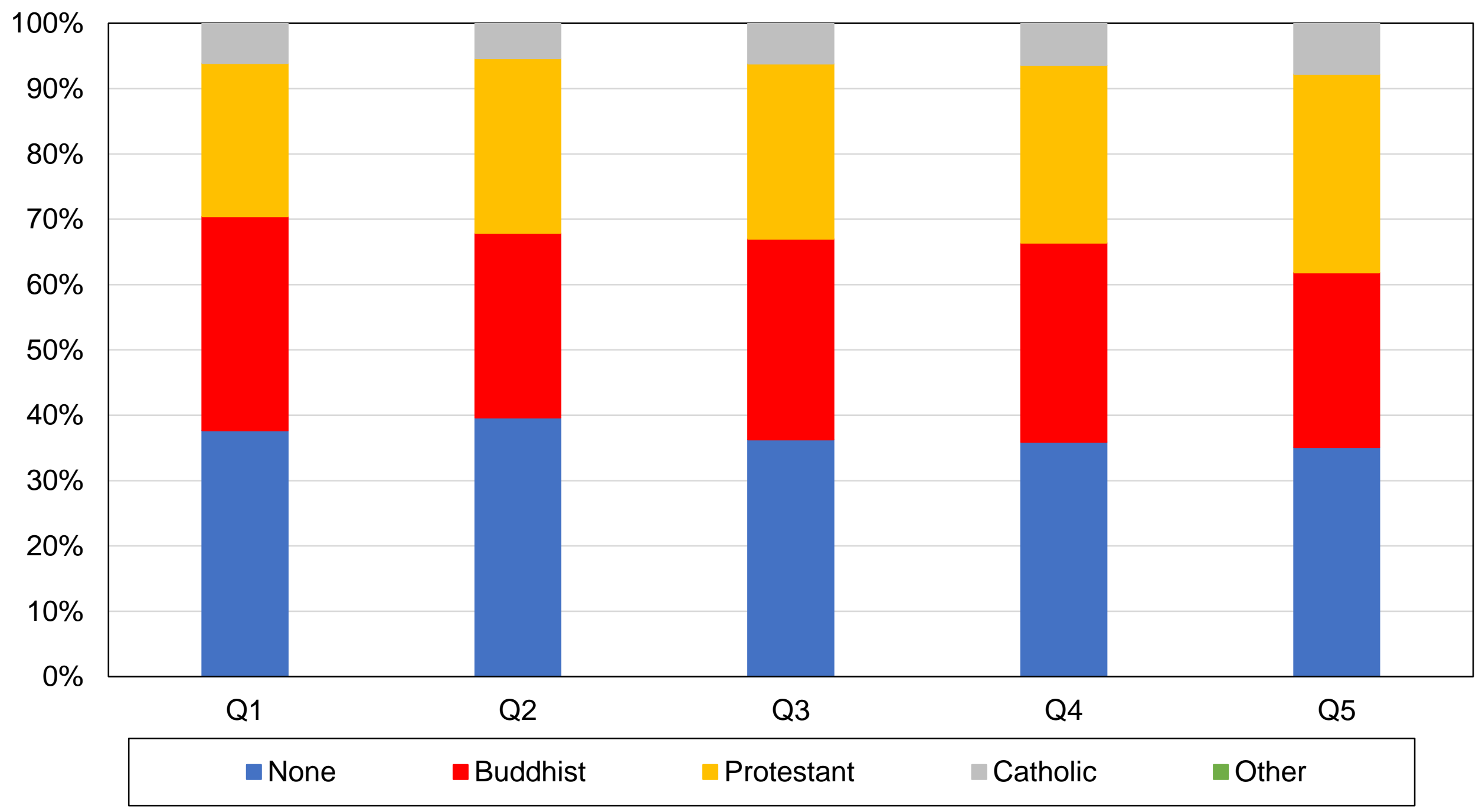

Source: authors' computations using South Korean political attitudes surveys.

Note: the figure shows the composition of income quintiles by religious affiliation in 2000 . 
Figure A22 - Composition of income quintiles by religion, 2016

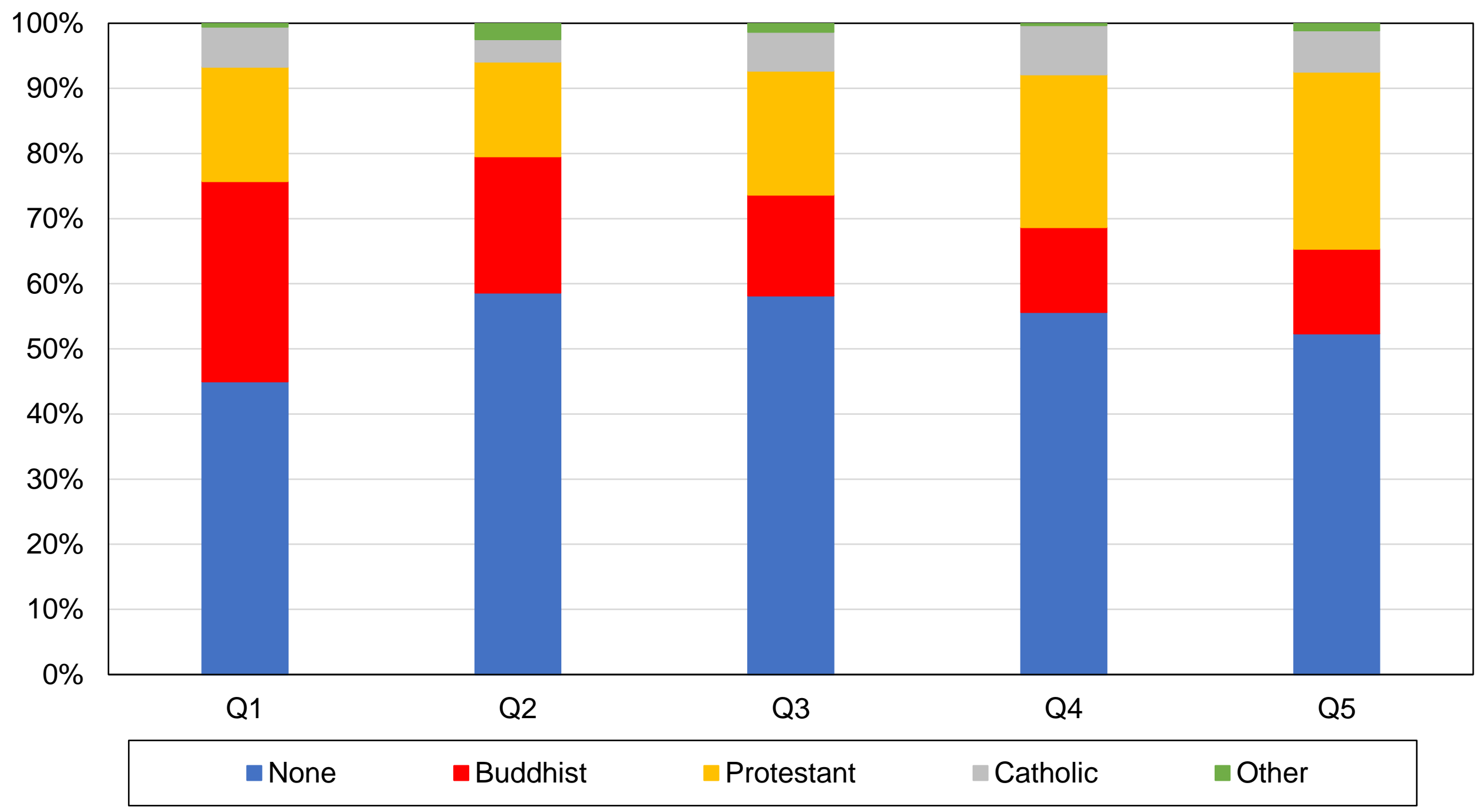

Source: authors' computations using South Korean political attitudes surveys.

Note: the figure shows the composition of income quintiles by religious affiliation in 2016 . 
Figure A23 - Composition of age groups by education level, 2000

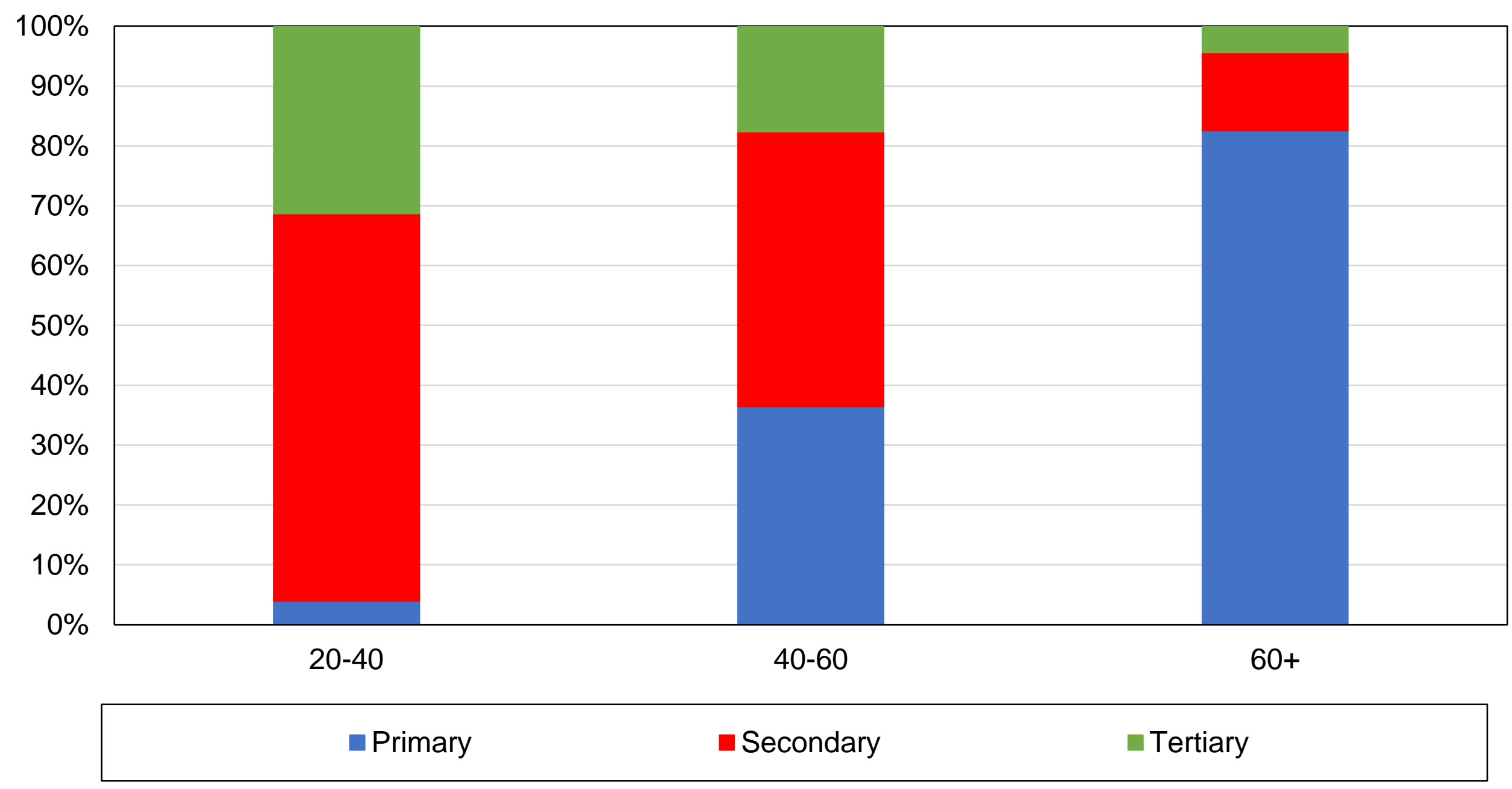

Source: authors' computations using South Korean political attitudes surveys.

Note: the figure shows the composition of age groups by education level in 2000 . 
Figure A24 - Composition of age groups by education level, 2016

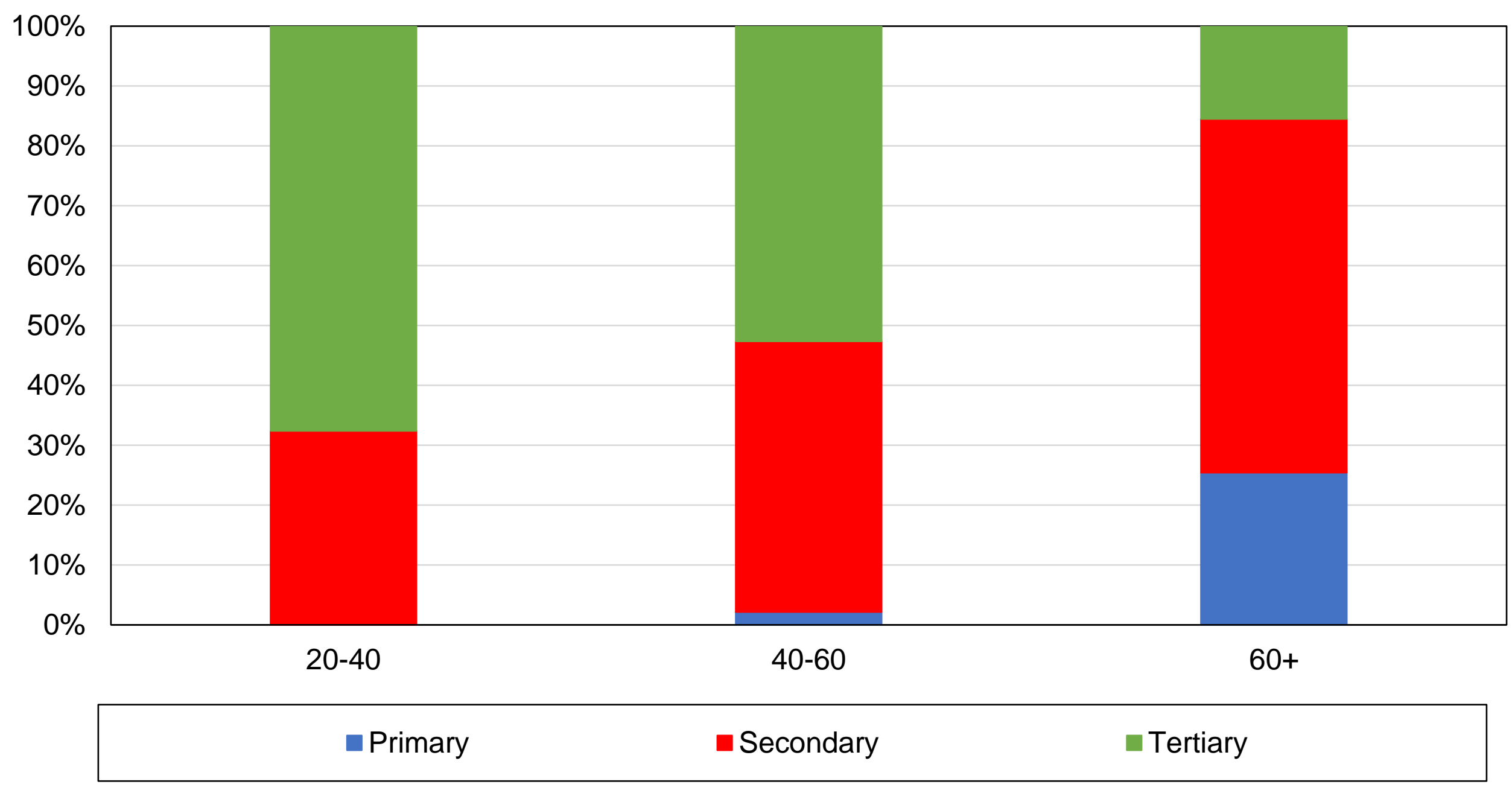

Source: authors' computations using South Korean political attitudes surveys.

Note: the figure shows the composition of age group by education level in 2016 . 
Figure A25 - Vote for the Hannara / Saenuri Party by region

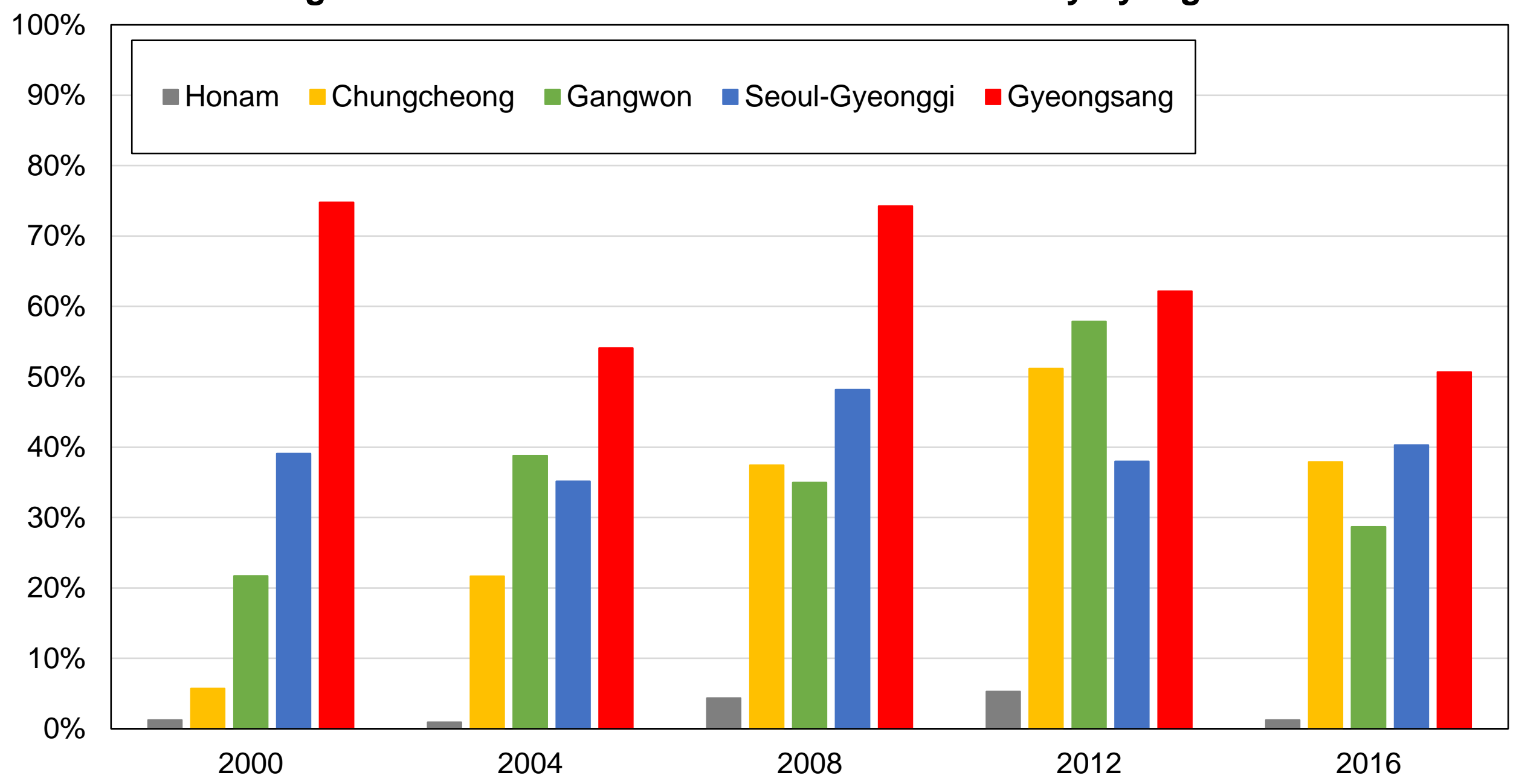

Source: authors' computations using South Korean political attitudes surveys.

Note: the figure shows the share of votes received by the Hannara / Saenuri Party by region. In 2016 Honam represented approximately $10 \%$ the electorate, Chungcheong 10\%, Gangwon 4\%, SeoulGyeonggy 49\%, and Gyeongsang 26\%. 
Figure A26 - Vote for the Hannara / Saenuri Party by education level

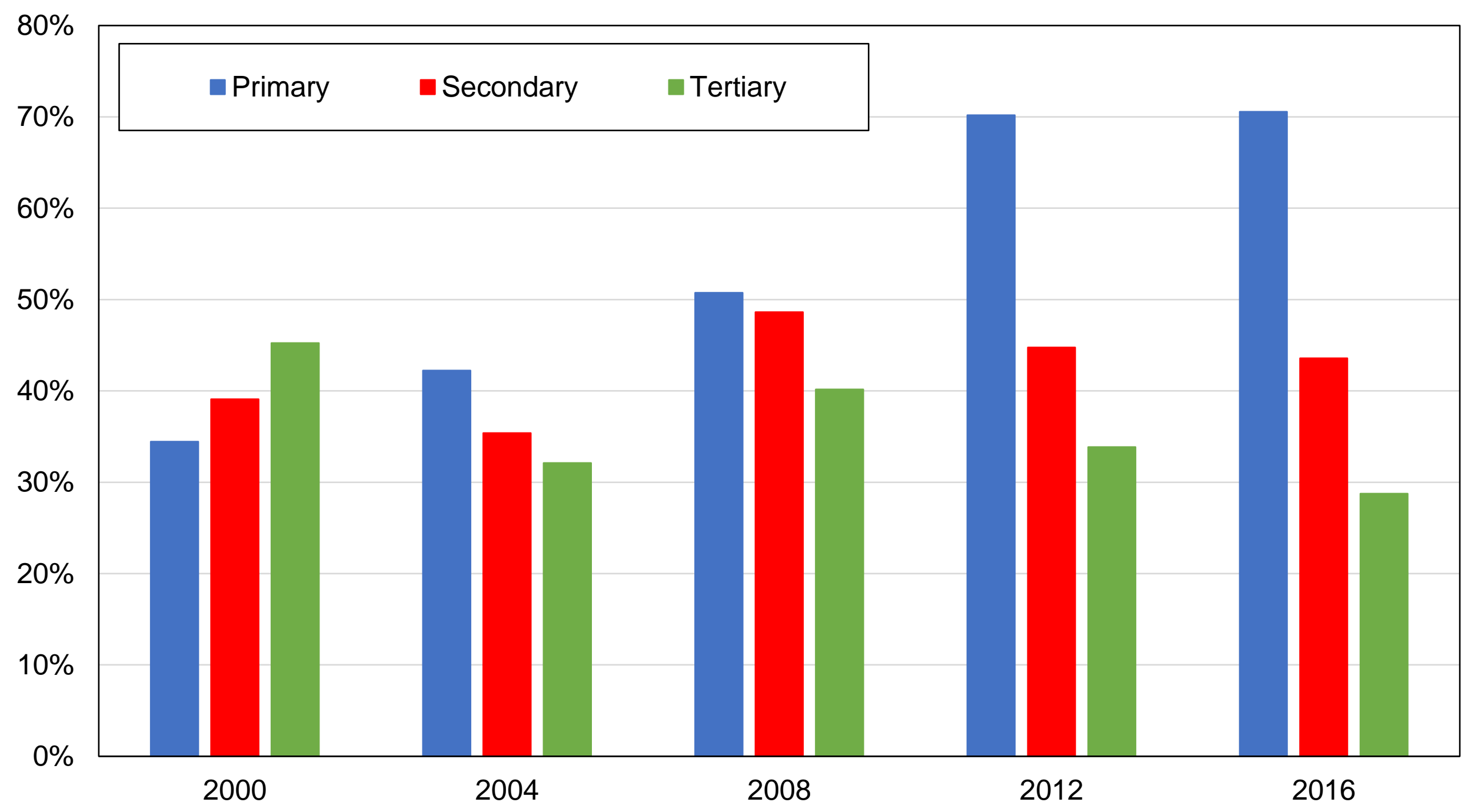

Source: authors' computations using South Korean political attitudes surveys.

Note: the figure shows the share of votes received by the Hannara / Saenuri Party by education level. 
Figure A27 - Vote for the Hannara / Saenuri Party by education group

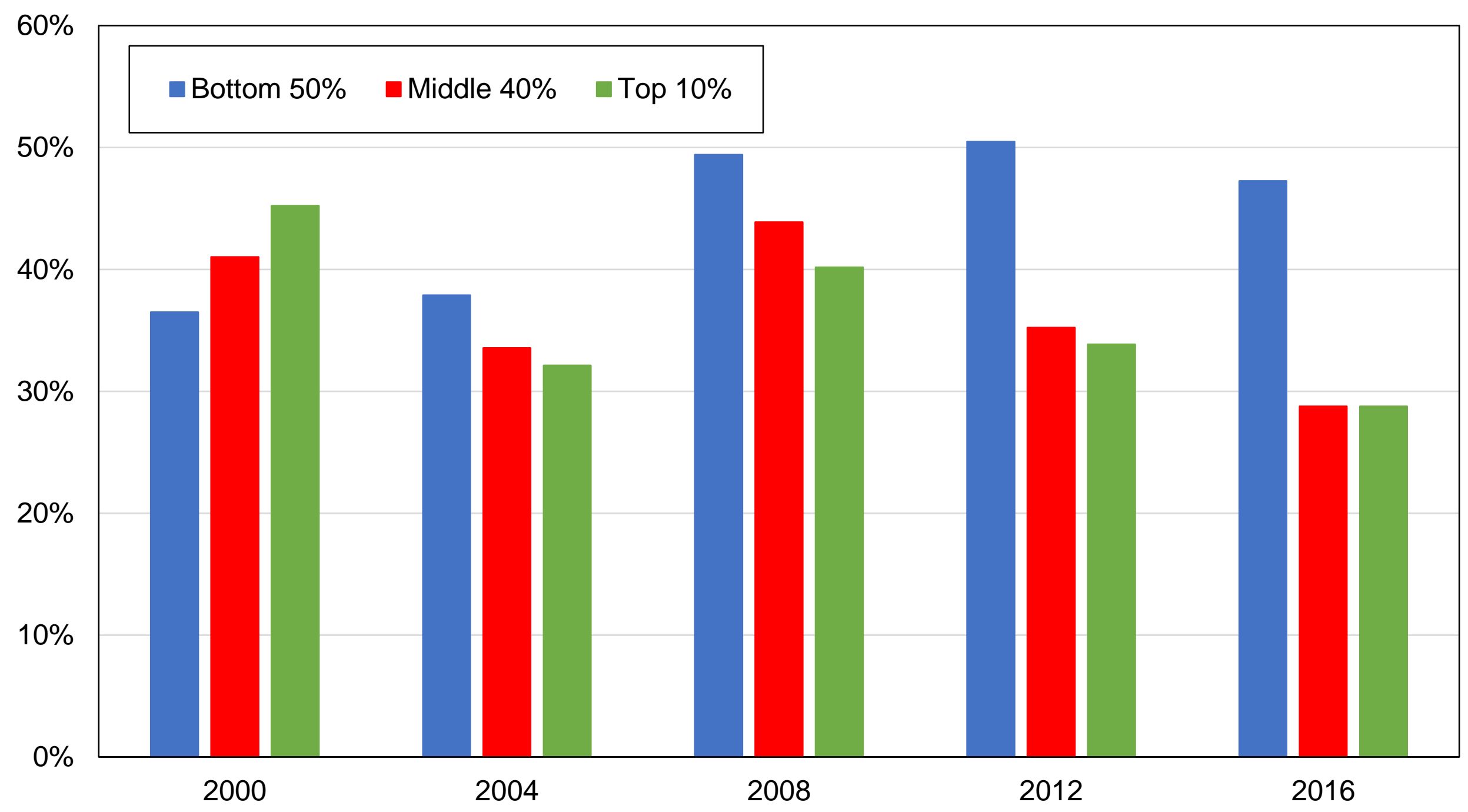

Source: authors' computations using South Korean political attitudes surveys.

Note: the figure shows the share of votes received by the Hannara / Saenuri Party by education group. 
Figure A28 - Vote for the Hannara / Saenuri Party by income quintile

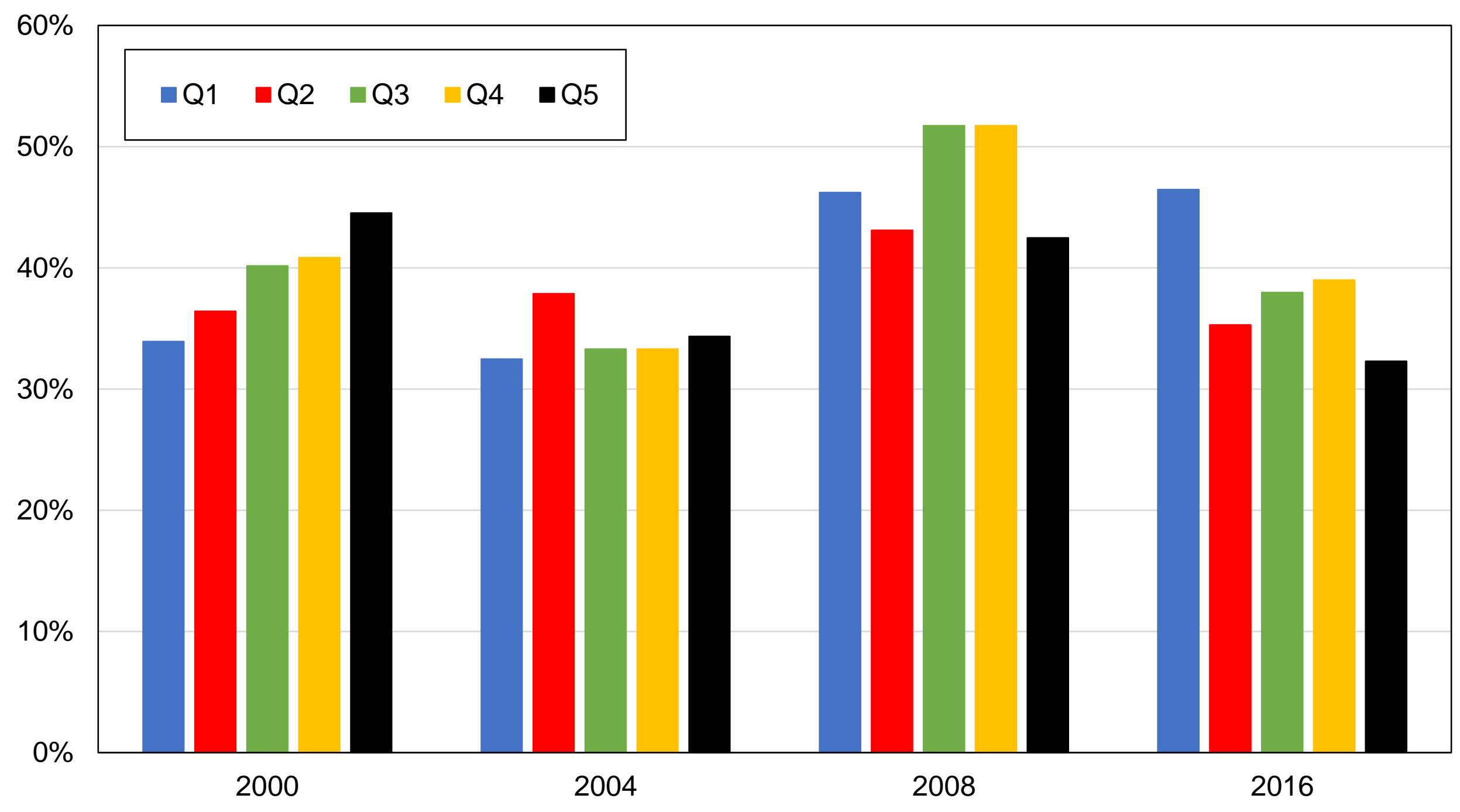

Source: authors' computations using South Korean political attitudes surveys.

Note: the figure shows the share of votes received by the Hannara / Saenuri Party by income quintile. 
Figure A26 - Vote for the Hannara / Saenuri Party by income quintile

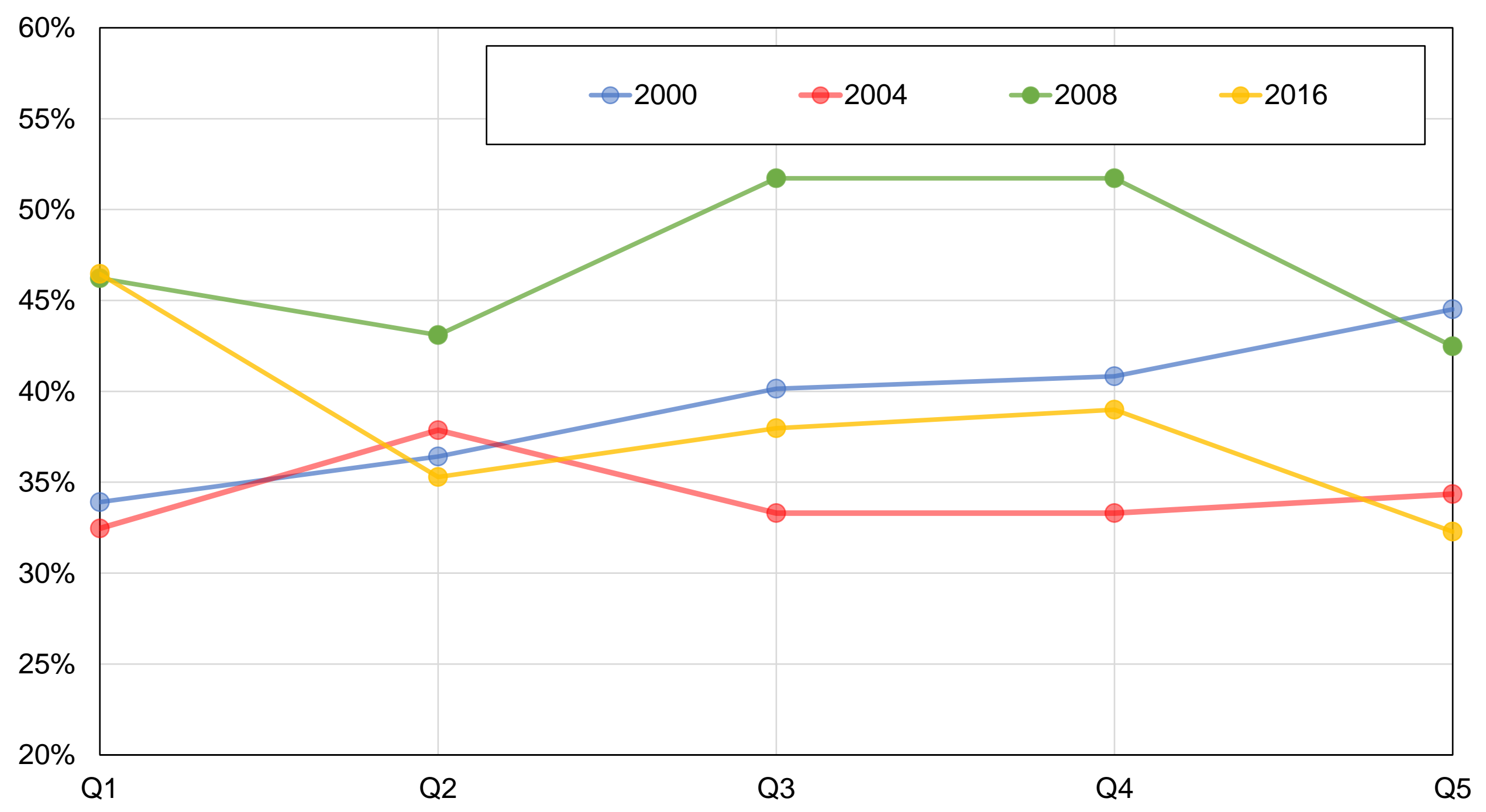

Source: authors' computations using South Korean political attitudes surveys.

Note: the figure shows the share of votes received by the Hannara / Saenuri Party by income quintile. 
Figure A30 - Vote for the Hannara / Saenuri Party by income group

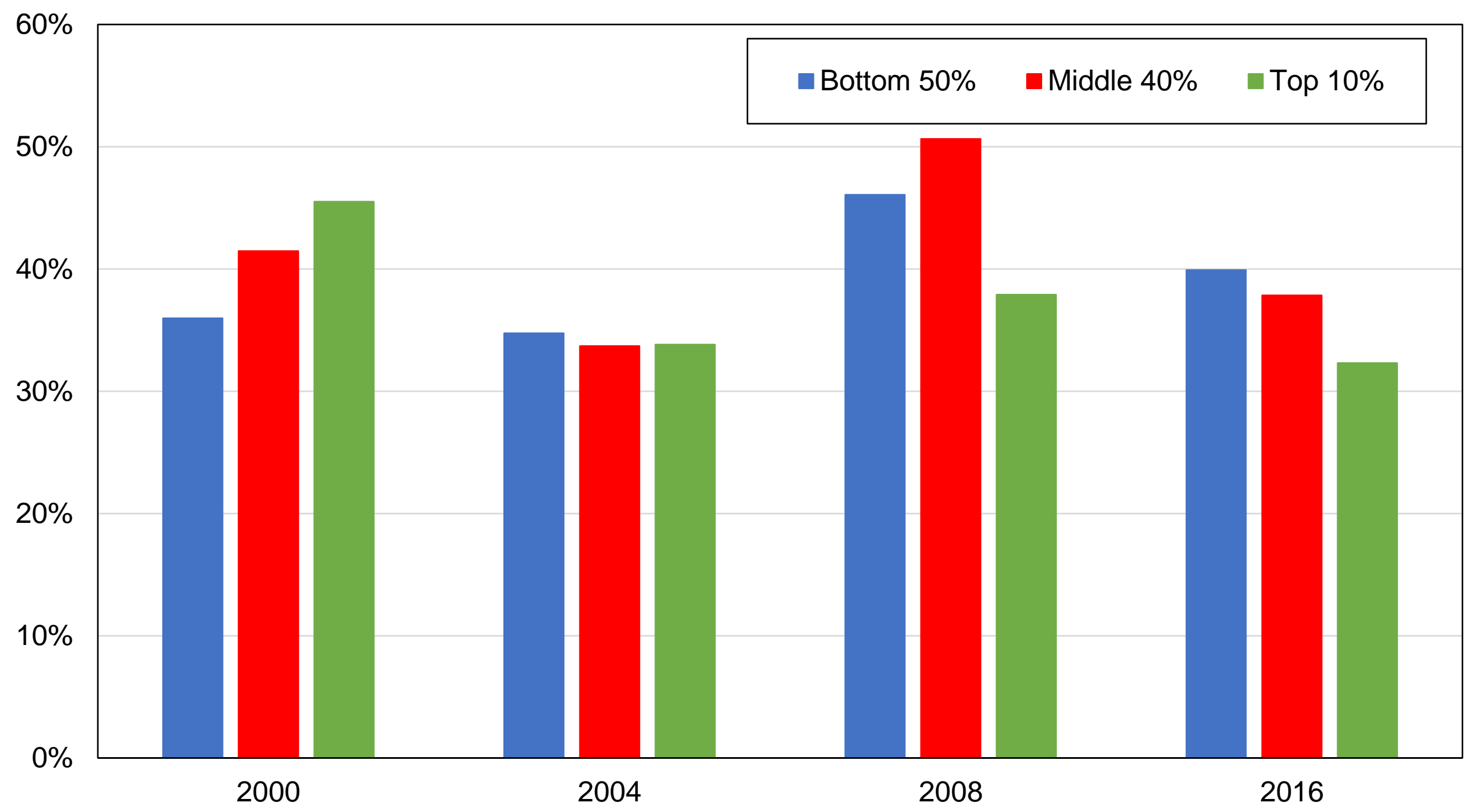

Source: authors' computations using South Korean political attitudes surveys.

Note: the figure shows the share of votes received by the Hannara / Saenuri Party by income group. 
Figure A31 - Vote for the Hannara / Saenuri Party by gender

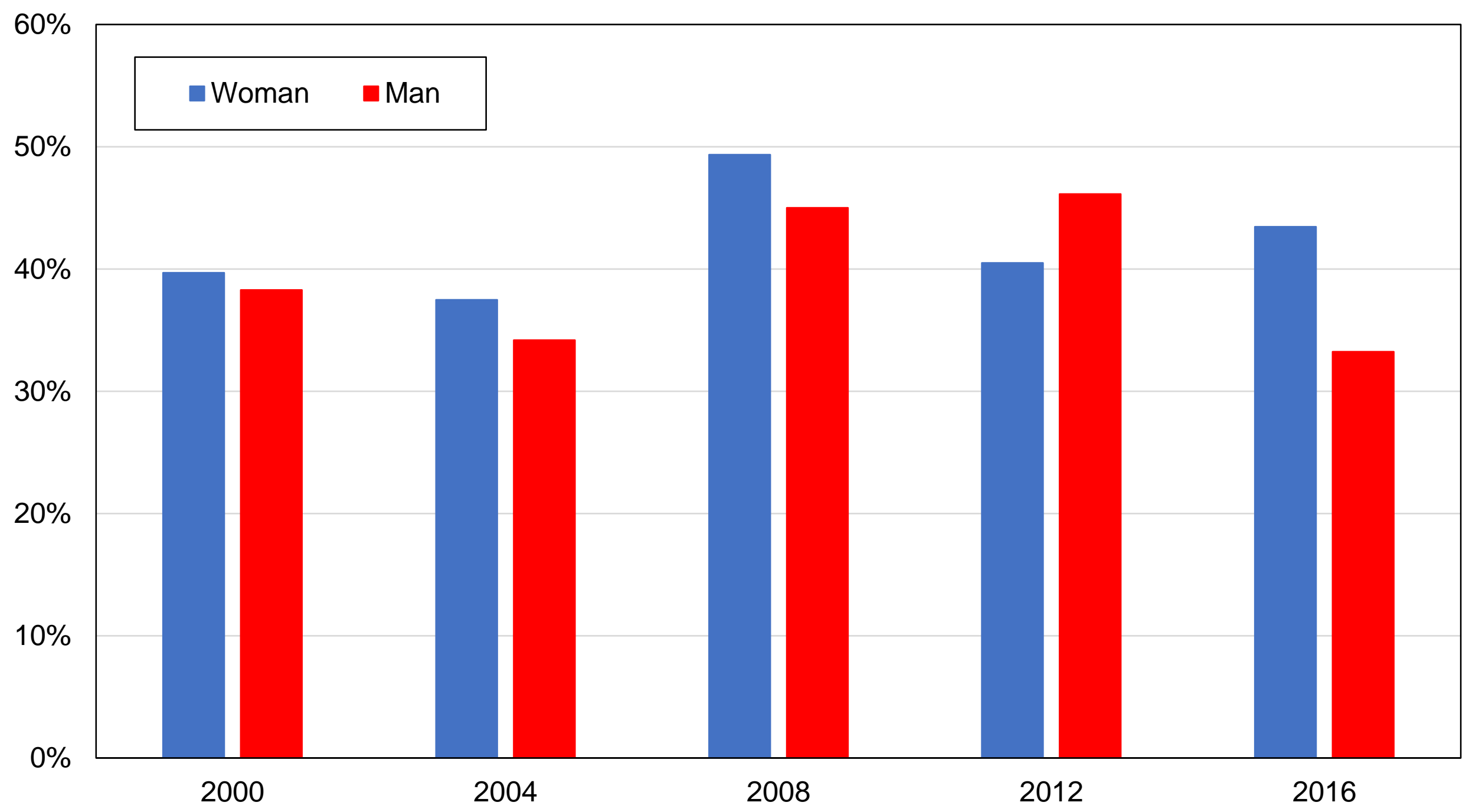

Source: authors' computations using South Korean political attitudes surveys.

Note: the figure shows the share of votes received by the Hannara / Saenuri Party by gender. 
Figure A32 - Vote for the Hannara / Saenuri Party by religion

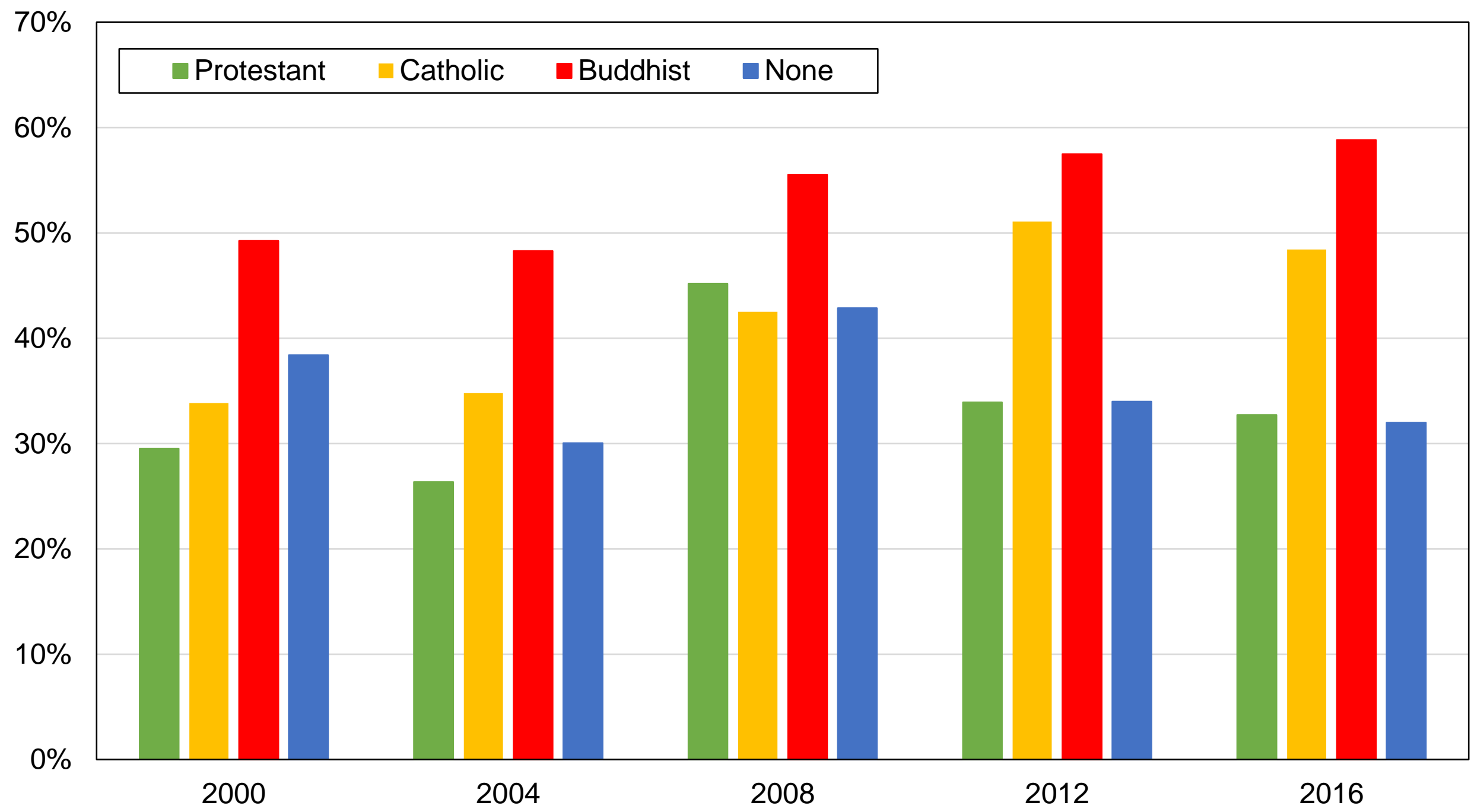

Source: authors' computations using South Korean political attitudes surveys.

Note: the figure shows the share of votes received by the Hannara / Saenuri Party by religious affiliation. 
Figure A33 - Vote for the Hannara / Saenuri Party by employment status

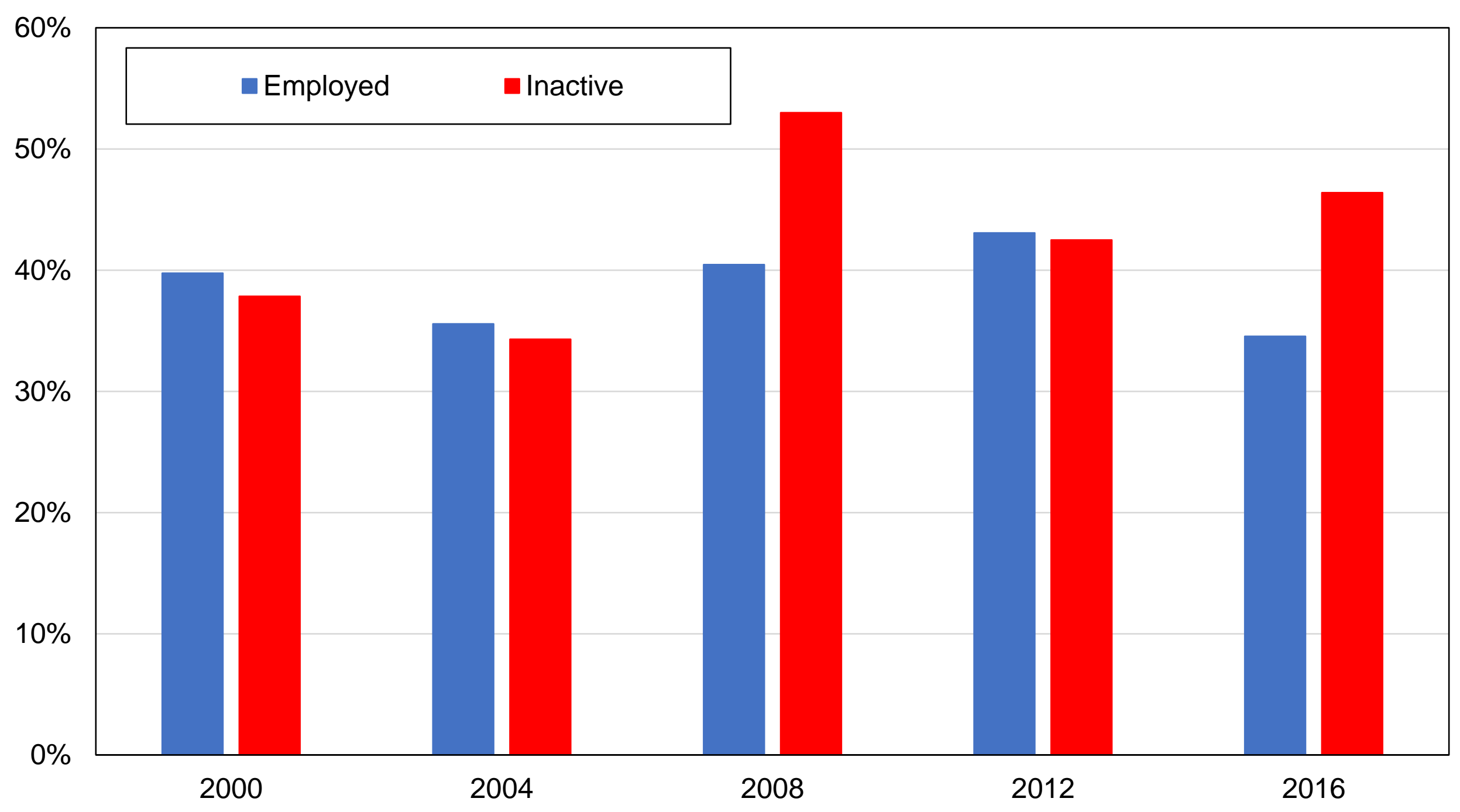

Source: authors' computations using South Korean political attitudes surveys.

Note: the figure shows the share of votes received by the Hannara / Saenuri Party by employment status. 
Figure A34 - Vote for the Hannara / Saenuri Party by marital status

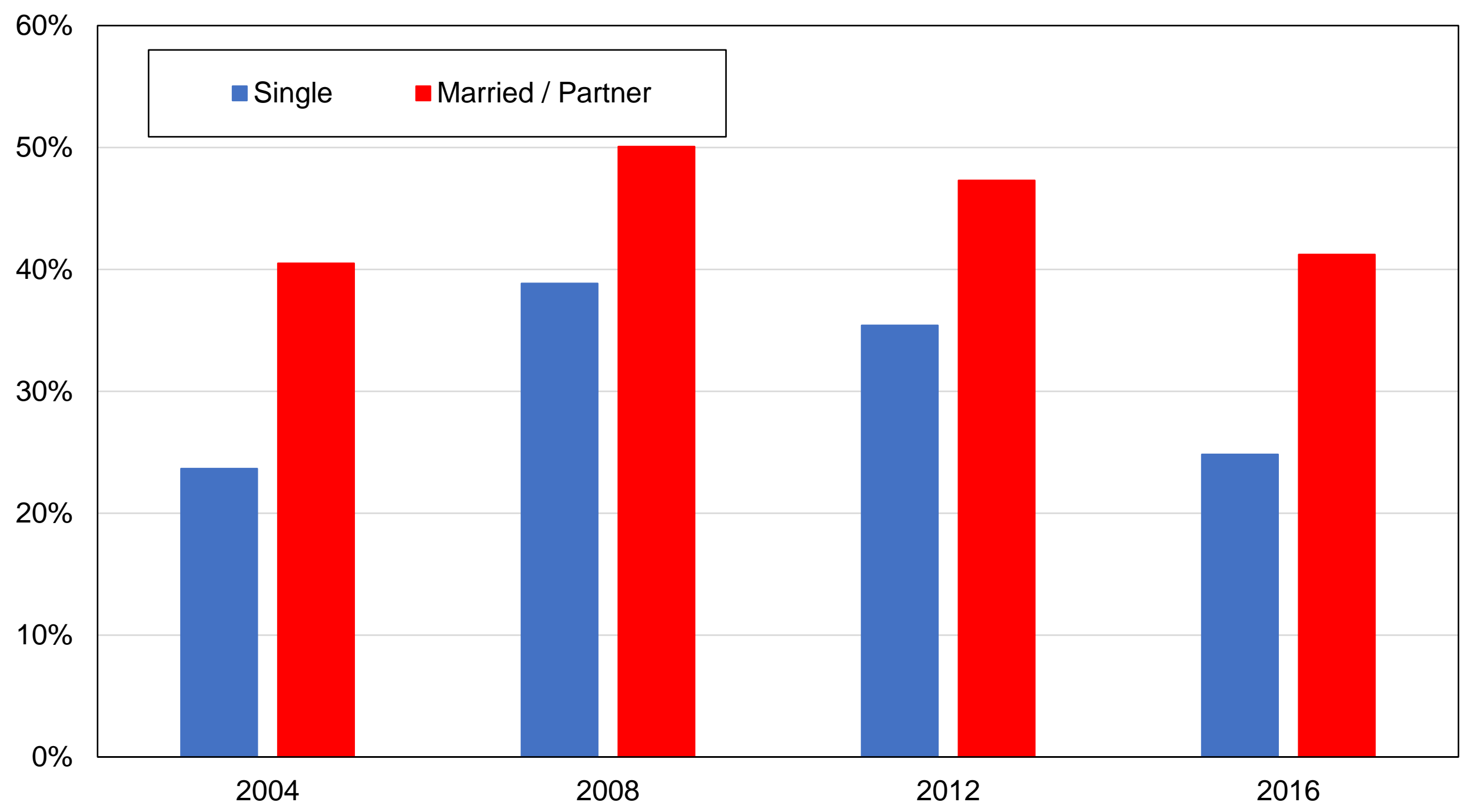

Source: authors' computations using South Korean political attitudes surveys.

Note: the figure shows the share of votes received by the Hannara / Saenuri Party by marital status. 


\section{Figure A35 - Vote for the Hannara / Saenuri Party among highest- educated and top-income voters}

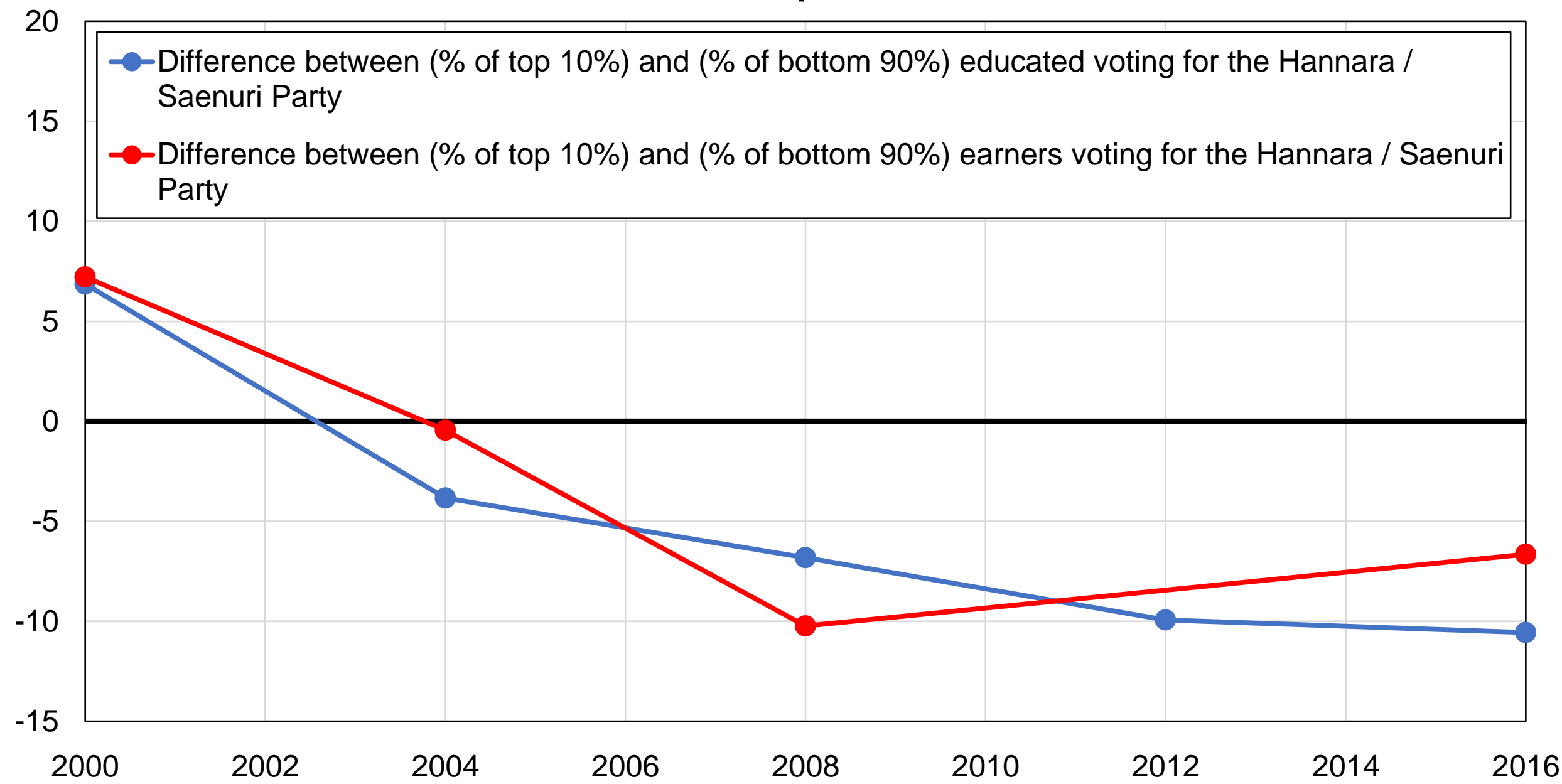

Source: authors' computations using South Korean political attitudes surveys.

Note: the figure shows the support for the Hannara / Saenuri Party among highest-educated and topincome voters. 


\section{Figure A36 - Vote for the Hannara / Saenuri Party among highest- educated and top-income voters, after controls}

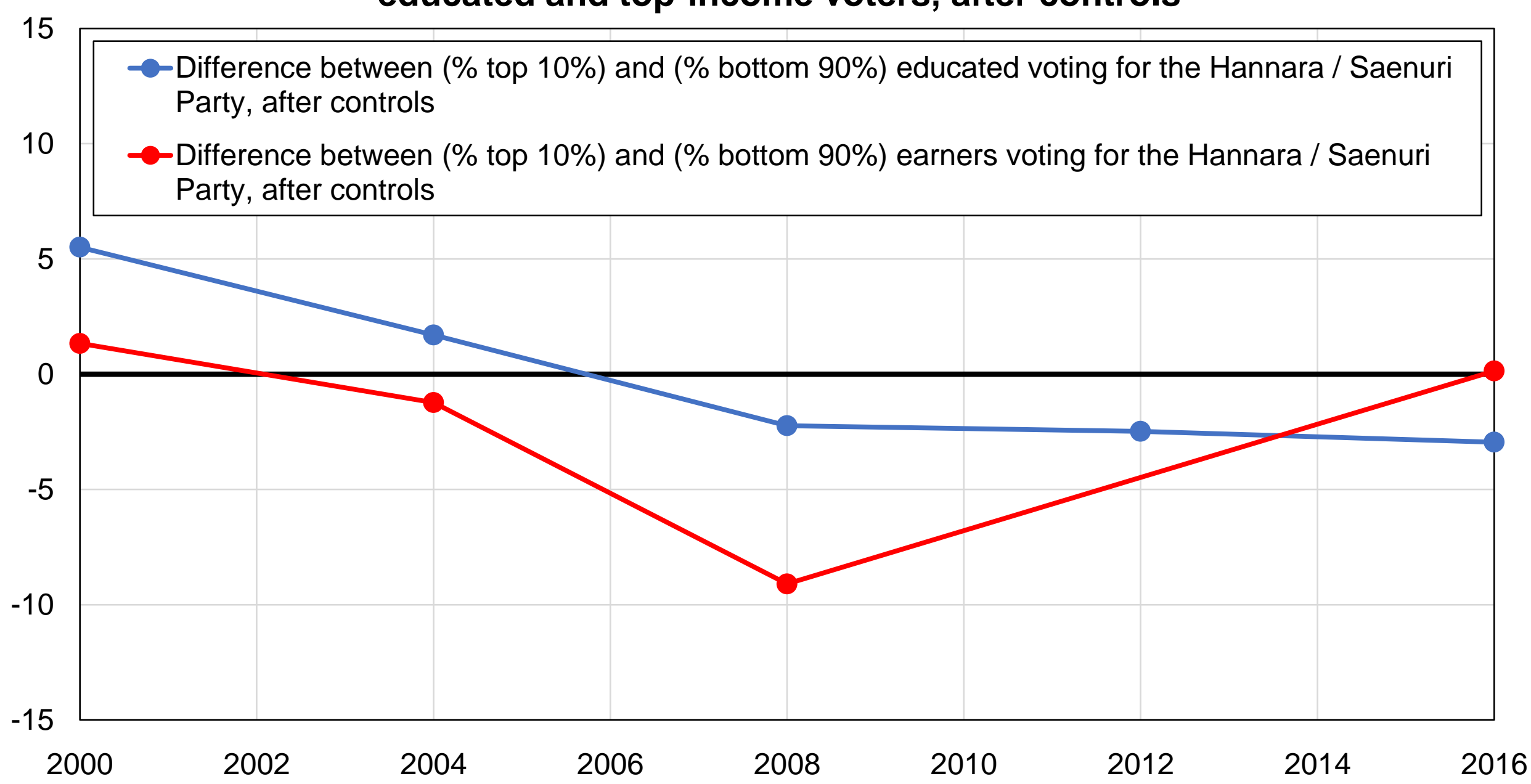

Source: authors' computations using South Korean political attitudes surveys.

Note: the figure shows the support for the Hannara / Saenuri Party among highest-educated and topincome voters, after controlling for other variables. 


\section{Figure A37 - Vote for the Hannara / Saenuri Party among young voters}

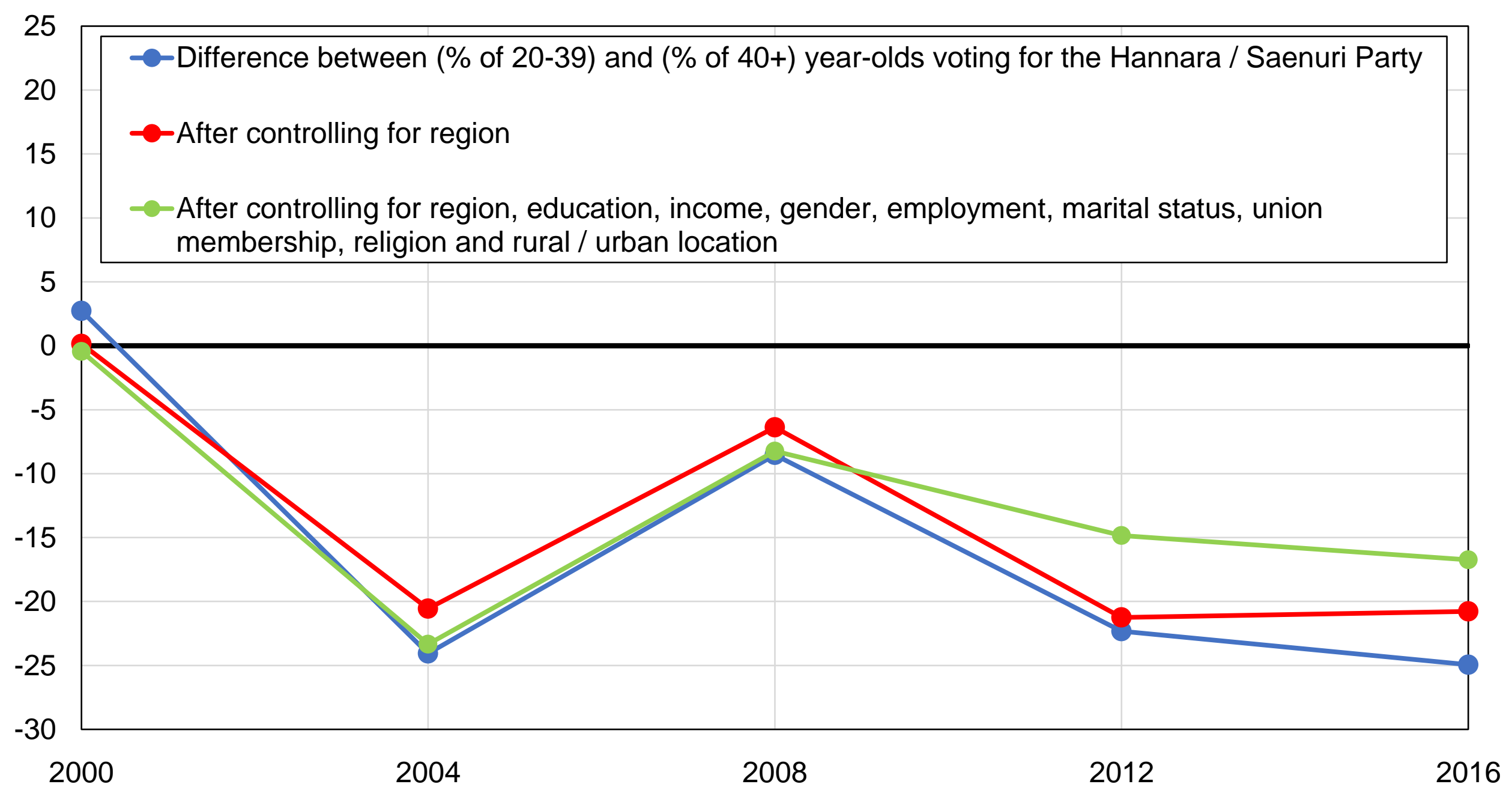

Source: authors' computations using South Korean political attitudes surveys.

Note: the figure shows the difference between the share of voters aged 20-39 and the share of voters older than 40 voting for the Hannara / Saenuri Party, before and after controlling for other variables. 


\section{Figure A38 - Vote for the Hannara / Saenuri Party among old voters}

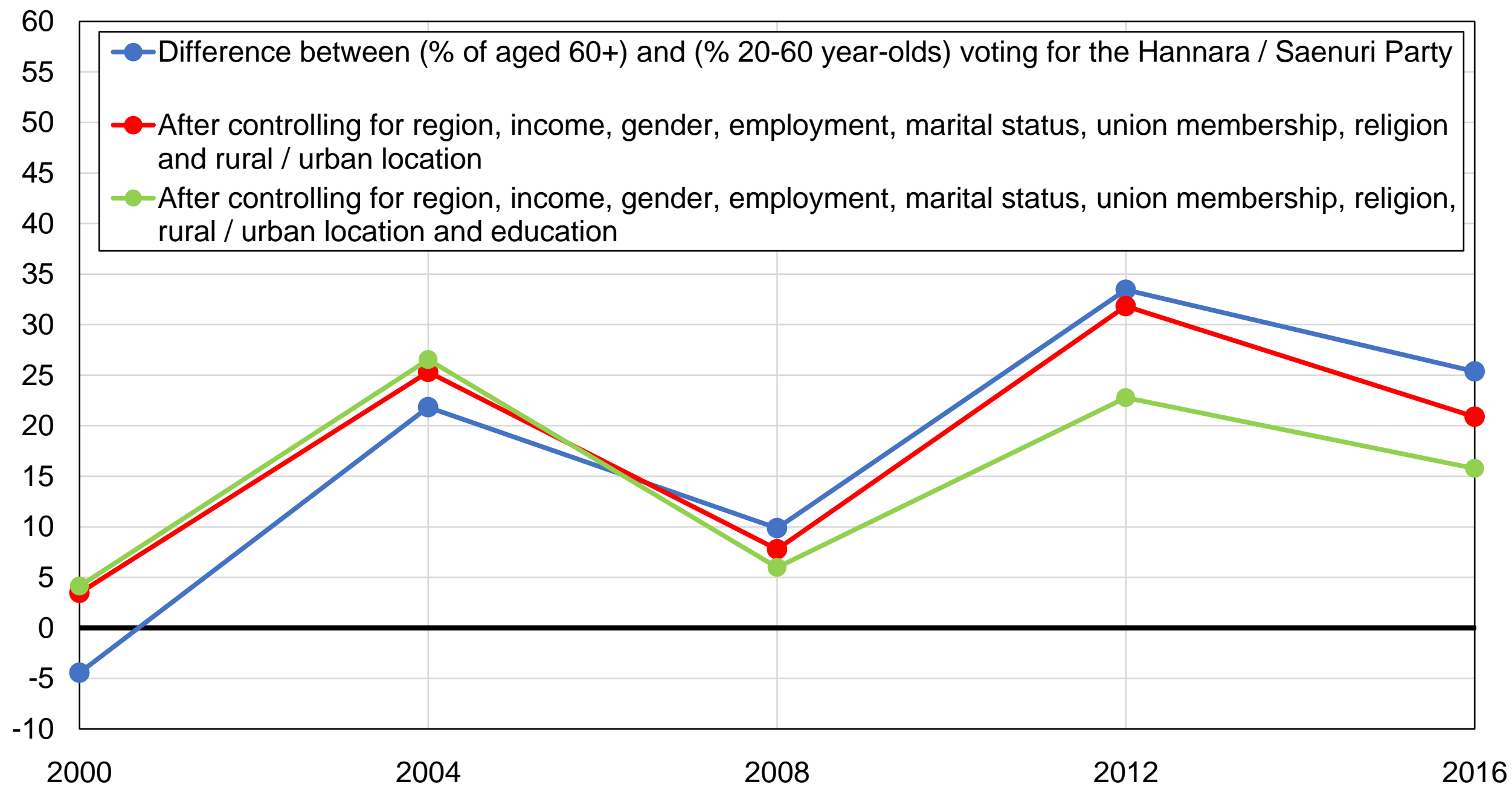

Source: authors' computations using South Korean political attitudes surveys.

Note: the figure shows the difference between the share of voters aged $60+$ and the share of voters younger than 60 voting for the Hannara / Saenuri Party, before and after controlling for other variables. 


\section{Figure A39 - Vote for the Hannara / Saenuri Party among highest- educated voters}

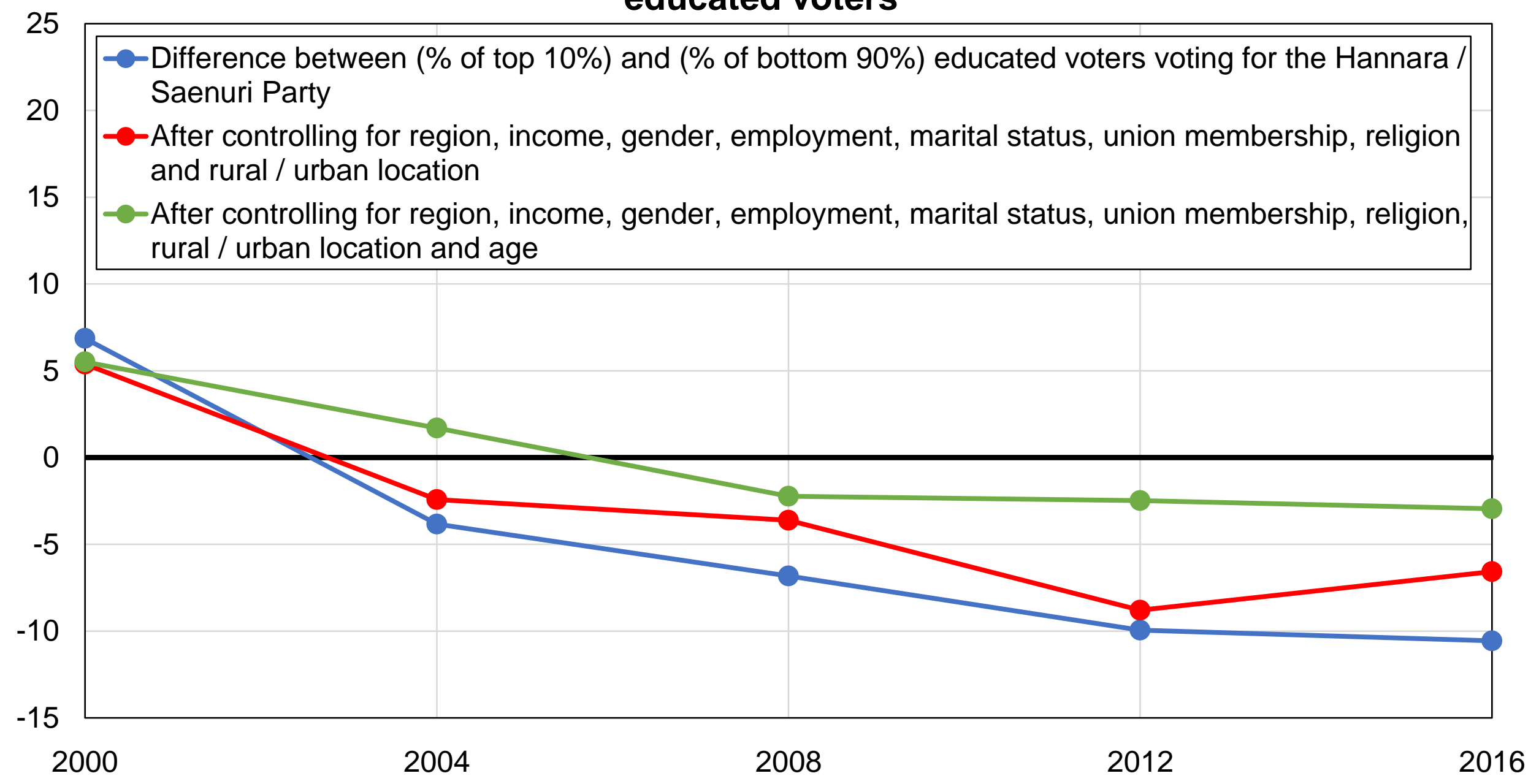

Source: authors' computations using South Korean political attitudes surveys.

Note: the figure shows the difference between the share of top $10 \%$ educated voters and the share of other voters voting for the Hannara / Saenuri Party, before and after controlling for other variables. 


\section{Figure A40 - Vote for the Hannara / Saenuri Party among low-educated voters}

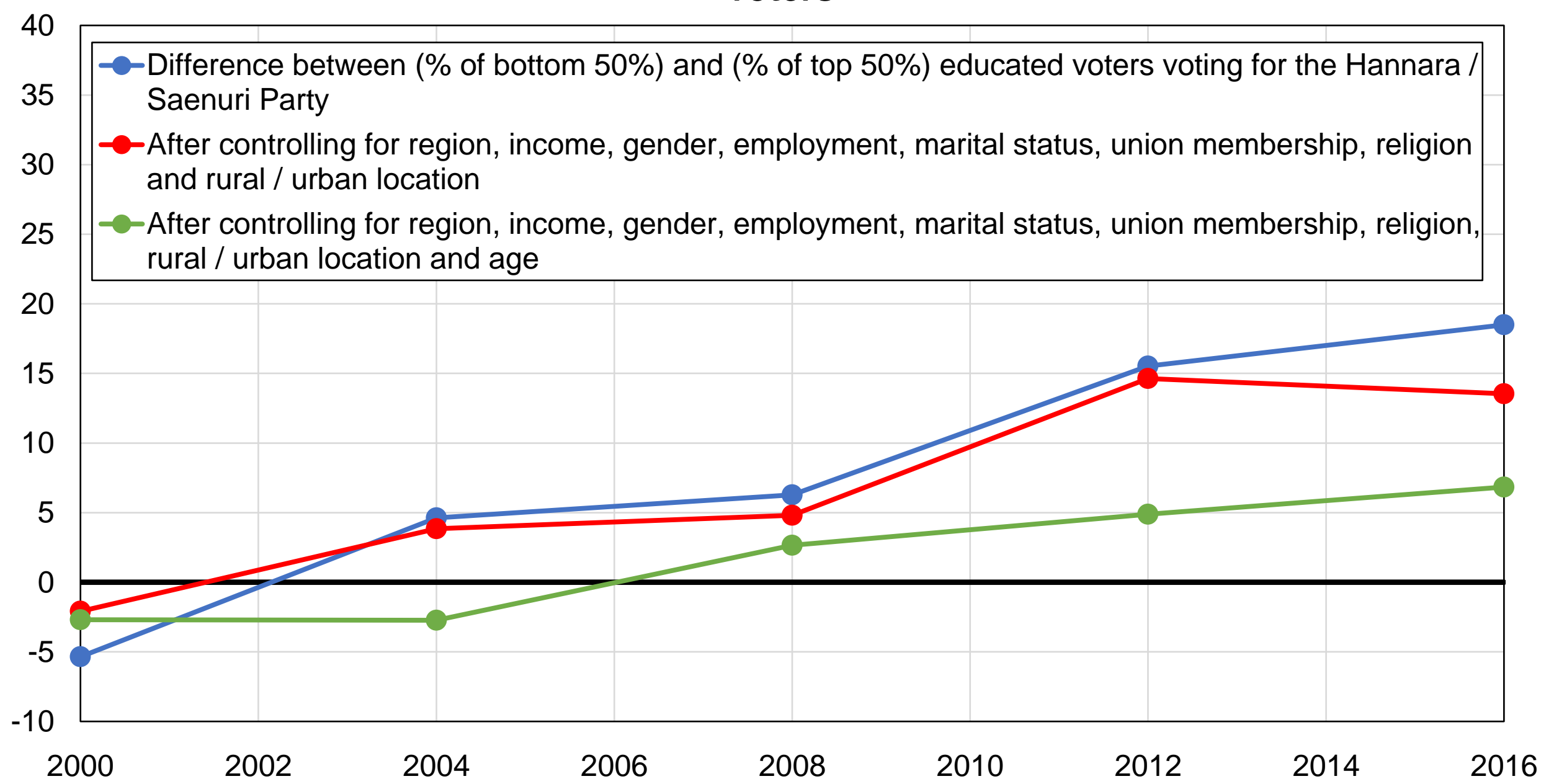

Source: authors' computations using South Korean political attitudes surveys.

Note: the figure shows the difference between the share of lower-educated voters and the share of other voters voting for the Hannara / Saenuri Party, before and after controlling for other variables. 


\section{Figure A41 - Vote for the Hannara / Saenuri Party among top-income voters}

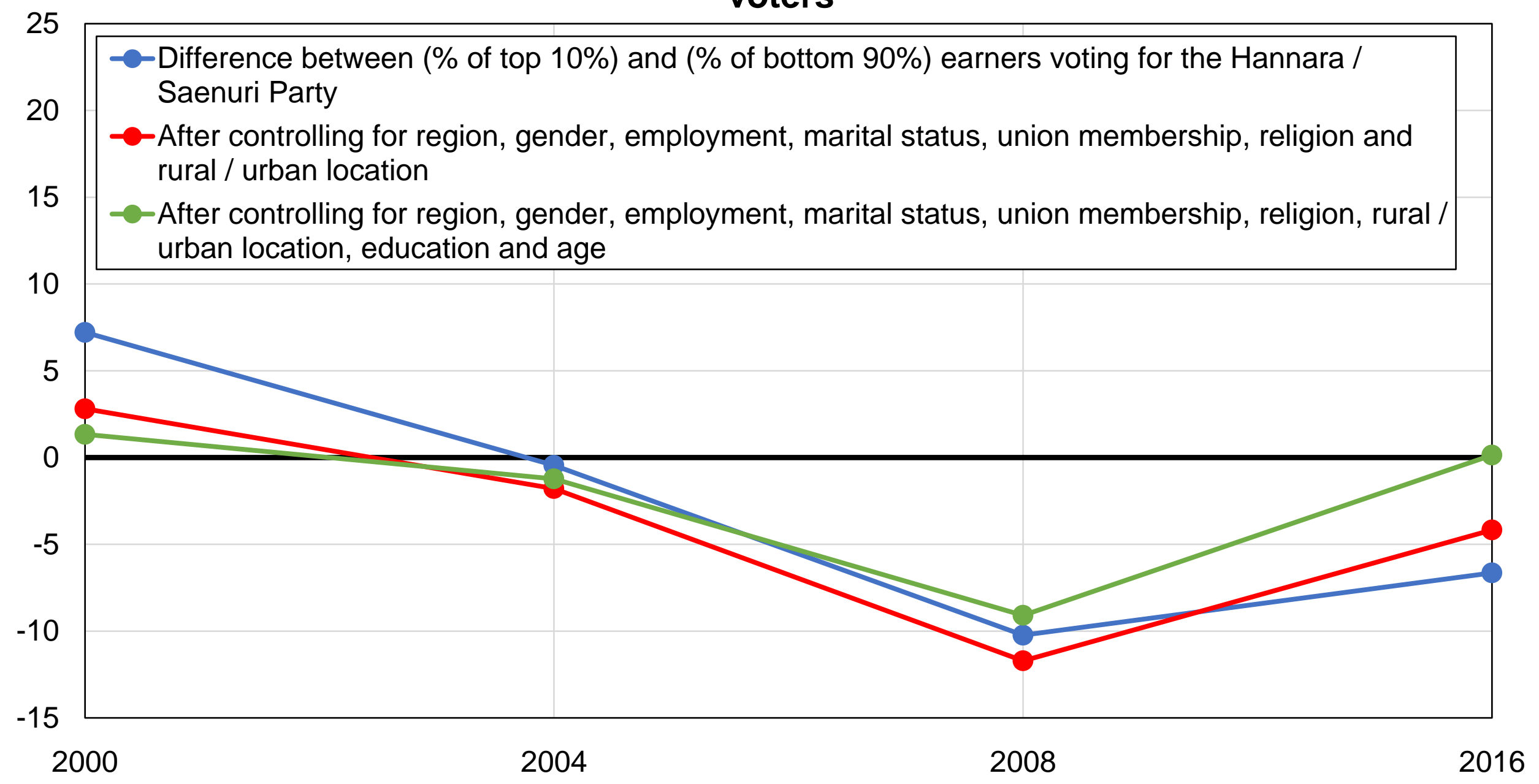

Source: authors' computations using South Korean political attitudes surveys.

Note: the figure shows the difference between the share of top $10 \%$ income voters and the share of bottom $90 \%$ income earners voting for the Hannara / Saenuri Party, before and after controlling for other variables. 


\section{Figure A42 - Vote for the Hannara / Saenuri Party among low-income voters}

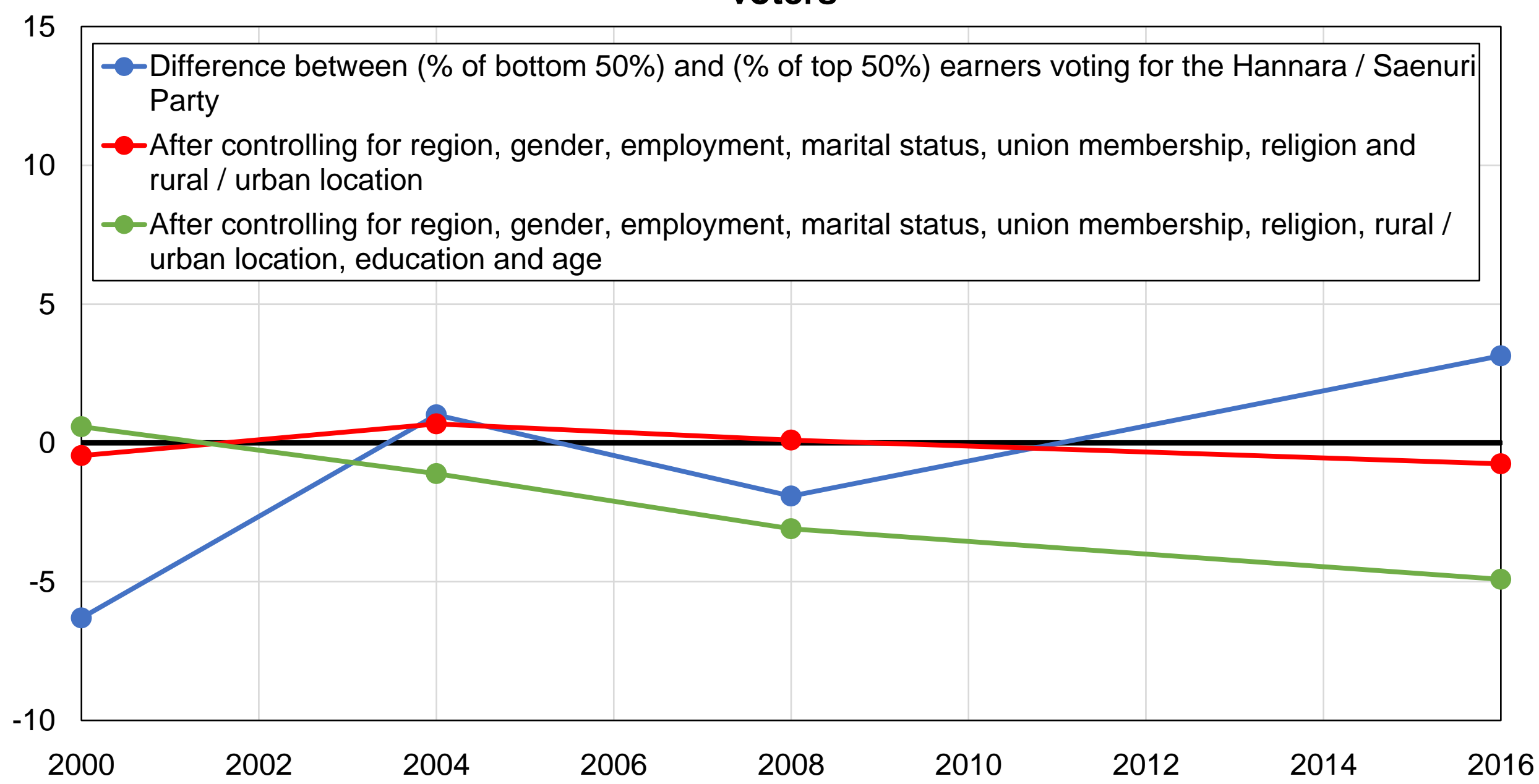

Source: authors' computations using South Korean political attitudes surveys.

Note: the figure shows the difference between the share of bottom $50 \%$ income earners and the share of top $50 \%$ income earners voting for the Hannara / Saenuri Party, before and after controlling for other variables. 


\section{Figure A43 - Vote for the Hannara / Saenuri Party among women}

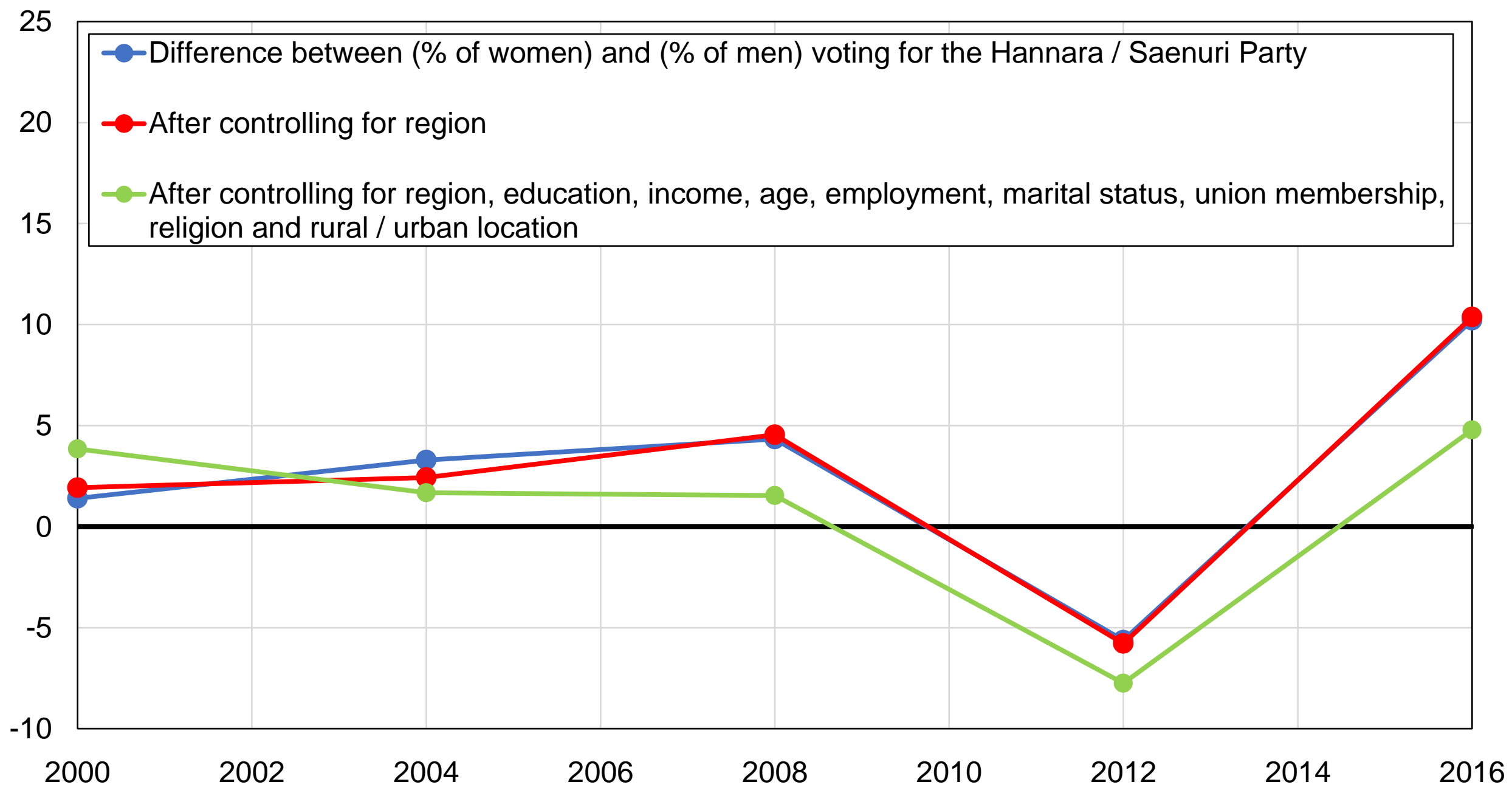

Source: authors' computations using South Korean political attitudes surveys.

Note: the figure shows the difference between the share of women and the share of men voting for the Hannara / Saenuri Party, before and after controlling for other variables. 


\section{Figure A44 - Vote for the Hannara / Saenuri Party among Buddhists}

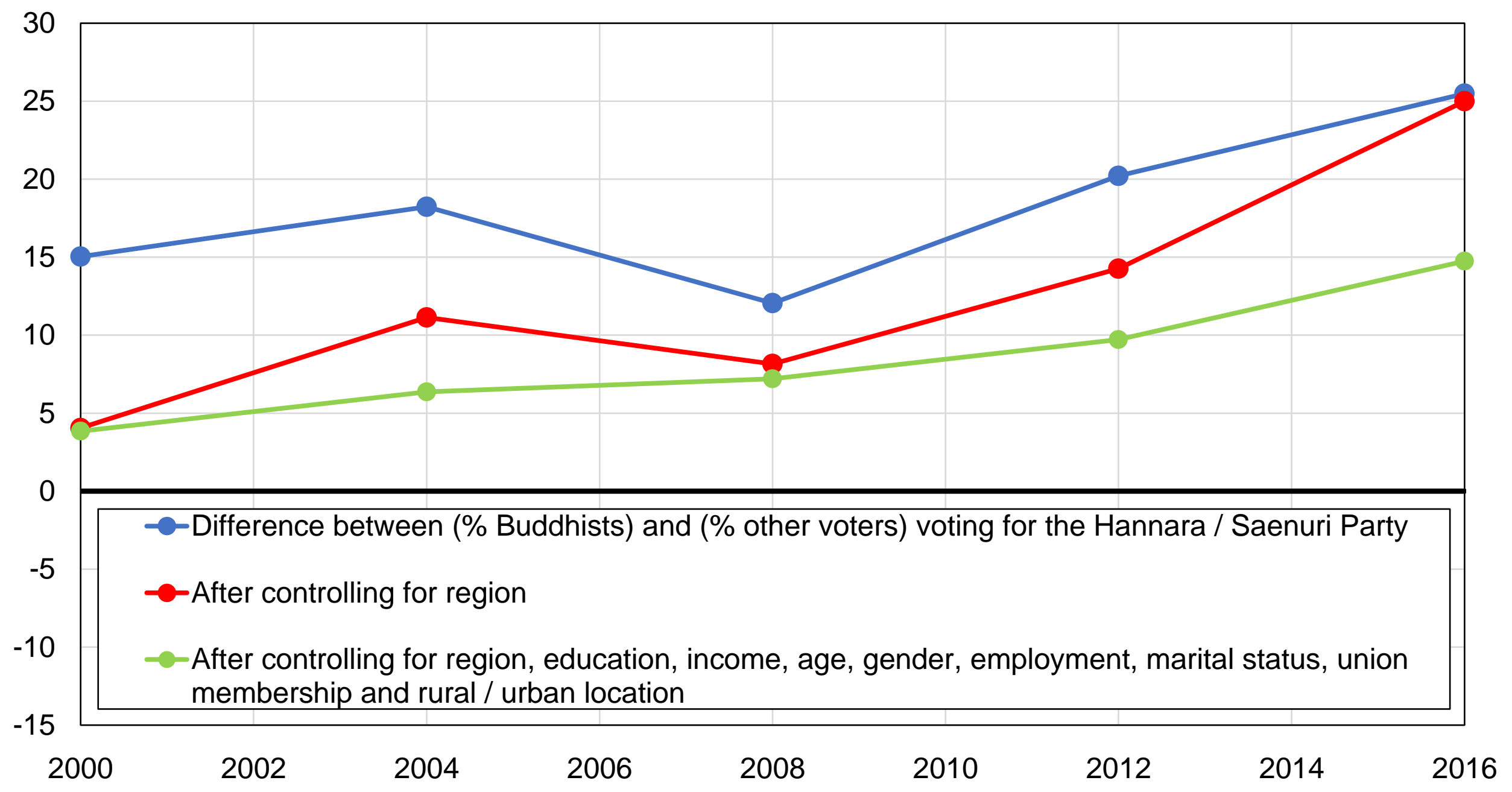

Source: authors' computations using South Korean political attitudes surveys.

Note: the figure shows the difference between the share of Buddhists and the share of other voters voting for the Hannara / Saenuri Party, before and after controlling for other variables. 
Figure A45 - Vote for the Hannara / Saenuri Party among non-single voters

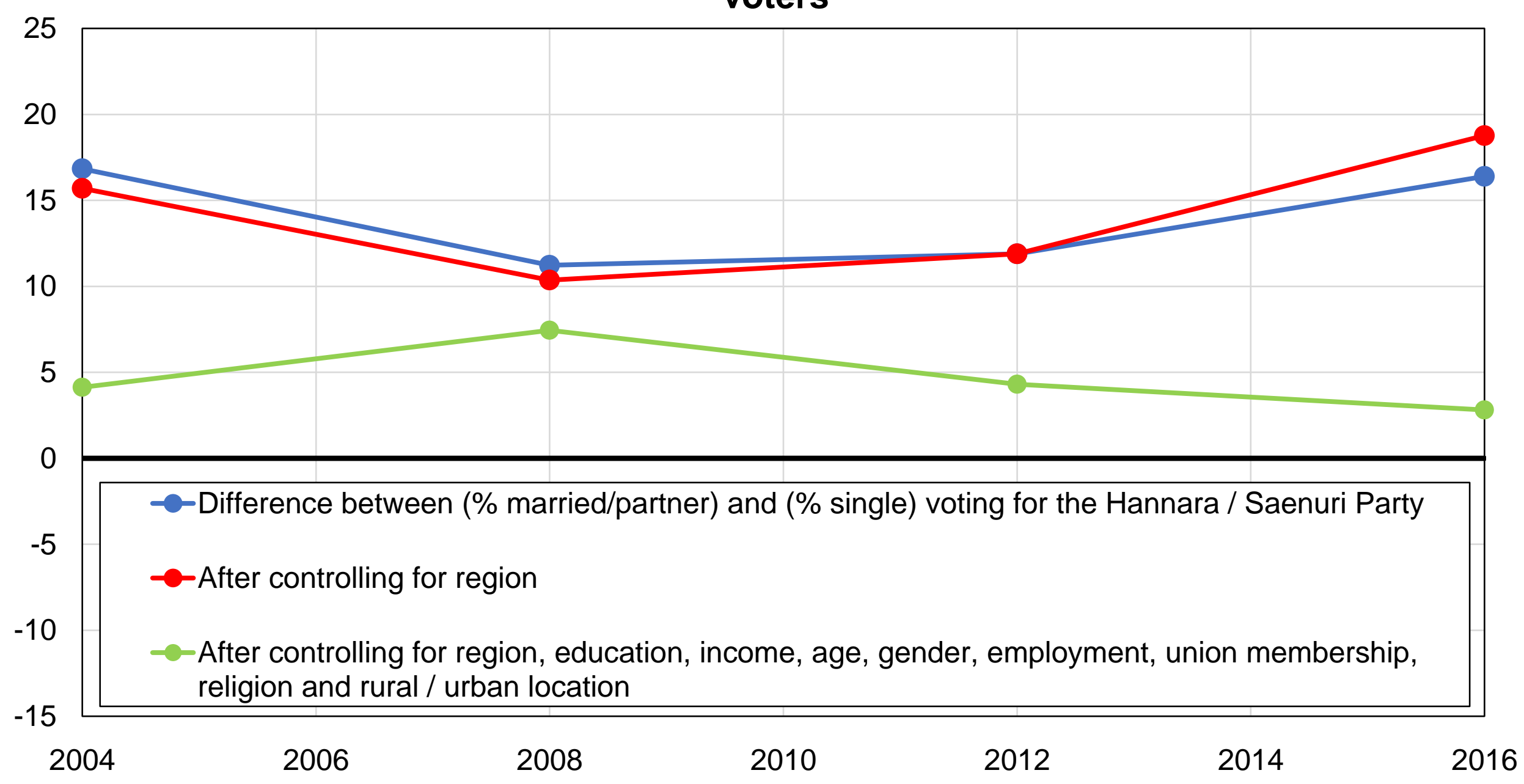

Source: authors' computations using South Korean political attitudes surveys.

Note: the figure shows the difference between the share of primary educated voters and the share of other voters voting for the Hannara / Saenuri Party, before and after controlling for other variables. 


\section{Figure A46 - The regional cleavage in South Korea}

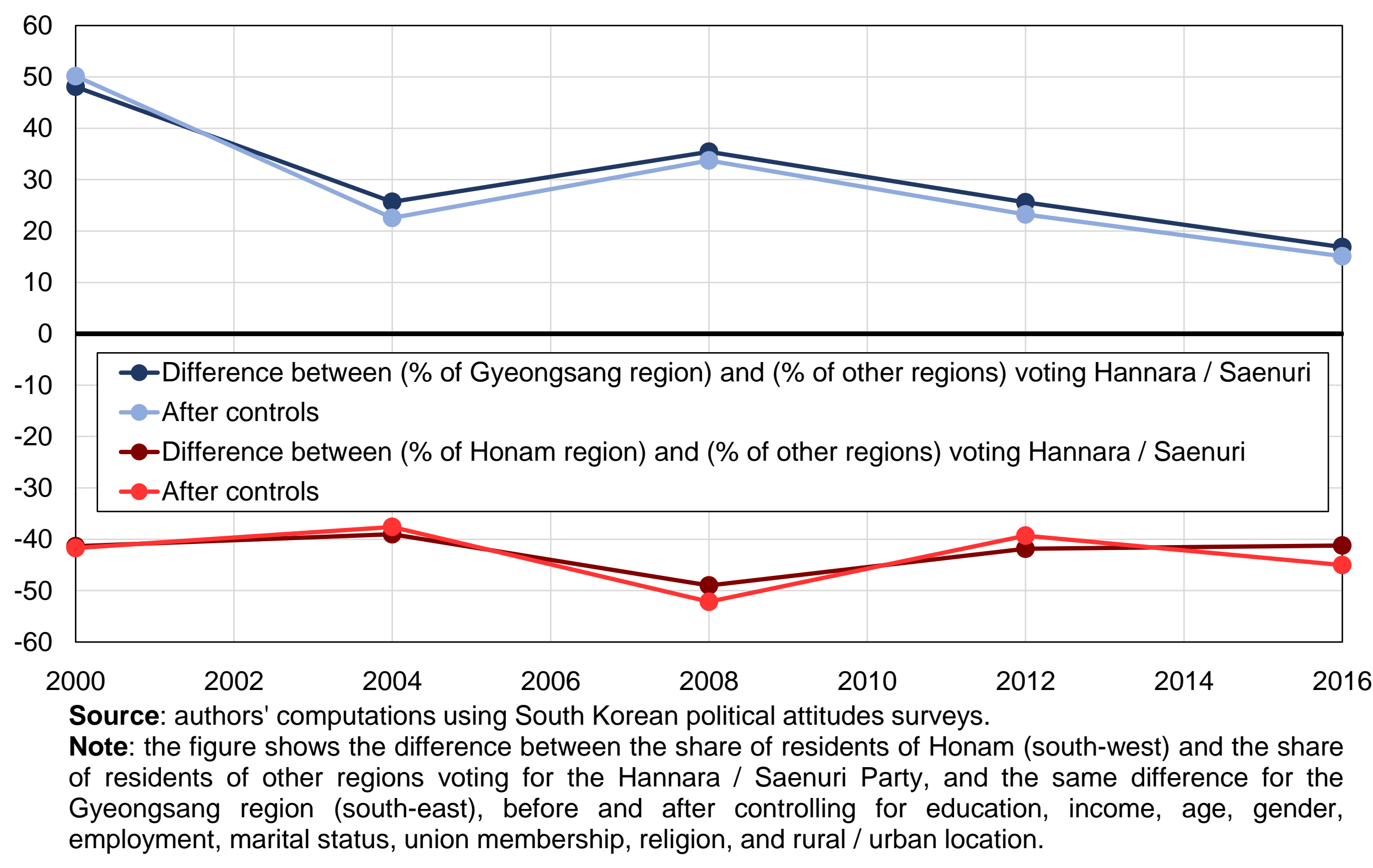


Table A1 - Survey data sources

\begin{tabular}{cccc} 
Year & Survey & Source & Sample size \\
\hline 1998 & Comparative Study of Electoral Systems & CSES & 691 \\
2000 & Comparative Study of Electoral Systems & CSES & 1124 \\
2004 & Comparative Study of Electoral Systems & CSES & 625 \\
2012 & Comparative Study of Electoral Systems & CSES & 743 \\
2016 & Comparative Study of Electoral Systems & CSES & 720
\end{tabular}

Source: authors' elaboration.

Note: the table shows the surveys used in the paper, the source from which these surveys can be obtained, and the sample size of each survey. CSES: Comparative Study of Electoral

System. 


\begin{tabular}{|c|c|c|c|c|c|}
\hline \multicolumn{6}{|c|}{ Table A2 - Complete descriptive statistics by year } \\
\hline & 2000 & 2004 & 2008 & 2012 & 2016 \\
\hline & $26 \%$ & $17 \%$ & $18 \%$ & $12 \%$ & $6 \%$ \\
\hline Education: Secondary & $51 \%$ & $51 \%$ & $49 \%$ & $43 \%$ & $44 \%$ \\
\hline Education: Tertiary & $23 \%$ & $32 \%$ & $33 \%$ & $45 \%$ & $50 \%$ \\
\hline Age: $20-40$ & $52 \%$ & $47 \%$ & $44 \%$ & $40 \%$ & $35 \%$ \\
\hline Age: $40-60$ & $35 \%$ & $45 \%$ & $41 \%$ & $43 \%$ & $44 \%$ \\
\hline Age: $60_{+}$ & $13 \%$ & $8 \%$ & $15 \%$ & $17 \%$ & $21 \%$ \\
\hline Gender: Man & $49 \%$ & $49 \%$ & $49 \%$ & $49 \%$ & $50 \%$ \\
\hline Employment status: Employed & $60 \%$ & $57 \%$ & $54 \%$ & $61 \%$ & $68 \%$ \\
\hline Employment status: Unemployed & $8 \%$ & $7 \%$ & $3 \%$ & $5 \%$ & $1 \%$ \\
\hline Employment status: Inactive & $32 \%$ & $36 \%$ & $43 \%$ & $35 \%$ & $31 \%$ \\
\hline Marital status: Married / With partner & & $66 \%$ & $63 \%$ & $60 \%$ & $76 \%$ \\
\hline Religion: None & $37 \%$ & $39 \%$ & $39 \%$ & $36 \%$ & $54 \%$ \\
\hline Religion: Buddhist & $30 \%$ & $30 \%$ & $27 \%$ & $28 \%$ & $19 \%$ \\
\hline Religion: Protestant & $27 \%$ & $18 \%$ & $21 \%$ & $24 \%$ & $20 \%$ \\
\hline Religion: Catholic & $6 \%$ & $12 \%$ & $11 \%$ & $9 \%$ & $6 \%$ \\
\hline Religion: Other & $0 \%$ & $1 \%$ & $1 \%$ & $3 \%$ & $1 \%$ \\
\hline Church attendance: Never & & $56 \%$ & $47 \%$ & $45 \%$ & \\
\hline Church attendance: Less than monthly & & $26 \%$ & $21 \%$ & $29 \%$ & \\
\hline Church attendance: Monthly or more & & $19 \%$ & $32 \%$ & $26 \%$ & \\
\hline Union membership: Yes & $2 \%$ & $4 \%$ & $6 \%$ & $5 \%$ & \\
\hline Rural / urban: Rural areas & $21 \%$ & $10 \%$ & $13 \%$ & $17 \%$ & $11 \%$ \\
\hline Region: Chungcheong-Daejon & $10 \%$ & $10 \%$ & $10 \%$ & $10 \%$ & $10 \%$ \\
\hline Region: Gangwon & $3 \%$ & $3 \%$ & $4 \%$ & $4 \%$ & $5 \%$ \\
\hline Region: Gyeonggi-Incheon-Seoul & $46 \%$ & $47 \%$ & $50 \%$ & $50 \%$ & $50 \%$ \\
\hline Region: Gyeongsang-Daegu-Busan-Ulsan & $28 \%$ & $28 \%$ & $25 \%$ & $26 \%$ & $26 \%$ \\
\hline Region: Jeolla-Gwangju & $12 \%$ & $12 \%$ & $10 \%$ & $10 \%$ & $10 \%$ \\
\hline $\begin{array}{l}\text { Source: authors' computations using South } \\
\text { Note: the table shows descriptive statistics }\end{array}$ & ean $p$ & al atti & s sur & the & \\
\hline
\end{tabular}


Table A3 - Determinants of the vote for the Hannara / Saenuri Party, 2000-2016

\begin{tabular}{|c|c|c|c|c|c|}
\hline & $\begin{array}{c}(1) \\
2000\end{array}$ & $\begin{array}{c}(2) \\
2004\end{array}$ & $\begin{array}{c}(3) \\
2008\end{array}$ & $\begin{array}{c}(4) \\
2016\end{array}$ & $\begin{array}{c}(5) \\
2000-2016\end{array}$ \\
\hline Region: Chungcheong & $\begin{array}{c}\text { (baseline) } \\
(.)\end{array}$ & $\begin{array}{c}\text { (baseline) } \\
(.)\end{array}$ & $\begin{array}{c}\text { (baseline) } \\
(.)\end{array}$ & $\begin{array}{c}\text { (baseline) } \\
(.)\end{array}$ & $\begin{array}{c}\text { (baseline) } \\
(.)\end{array}$ \\
\hline Region: Gangwon & $\begin{array}{c}0.162^{* * *} \\
(0.049)\end{array}$ & $\begin{array}{c}0.179^{* * *} \\
(0.057)\end{array}$ & $\begin{array}{l}-0.014 \\
(0.069)\end{array}$ & $\begin{array}{l}-0.058 \\
(0.080)\end{array}$ & $\begin{array}{l}0.081^{* *} \\
(0.033)\end{array}$ \\
\hline Region: Gyeongsang & $\begin{array}{l}0.674^{* * *} \\
(0.031)\end{array}$ & $\begin{array}{c}0.317^{* * *} \\
(0.032)\end{array}$ & $\begin{array}{l}0.351^{\star * *} \\
(0.045)\end{array}$ & $\begin{array}{l}0.118^{\star \star} \\
(0.050)\end{array}$ & $\begin{array}{c}0.382^{* * *} \\
(0.020)\end{array}$ \\
\hline Region: Honam & $\begin{array}{c}-0.048^{\star * *} \\
(0.018)\end{array}$ & $\begin{array}{l}-0.158^{\star \star *} \\
(0.031)\end{array}$ & $\begin{array}{l}-0.329^{* * *} \\
(0.039)\end{array}$ & $\begin{array}{c}-0.399^{* \star *} \\
(0.046)\end{array}$ & $\begin{array}{c}-0.208^{\star \star *} \\
(0.017)\end{array}$ \\
\hline Region: Seoul-Gyeonggi & $\begin{array}{c}0.361^{\star \star *} \\
(0.030)\end{array}$ & $\begin{array}{c}0.187^{\star \star \star} \\
(0.030)\end{array}$ & $\begin{array}{c}0.131^{* * *} \\
(0.042)\end{array}$ & $\begin{array}{c}0.041 \\
(0.046)\end{array}$ & $\begin{array}{c}0.202^{\star \star *} \\
(0.018)\end{array}$ \\
\hline Education: Primary & $\begin{array}{c}\text { (baseline) } \\
(.)\end{array}$ & $\begin{array}{c}\text { (baseline) } \\
(.)\end{array}$ & $\begin{array}{c}\text { (baseline) } \\
(.)\end{array}$ & $\begin{array}{c}\text { (baseline) } \\
(.)\end{array}$ & $\begin{array}{c}\text { (baseline) } \\
(.)\end{array}$ \\
\hline Education: Secondary & $\begin{array}{l}-0.003 \\
(0.034)\end{array}$ & $\begin{array}{l}0.049^{*} \\
(0.027)\end{array}$ & $\begin{array}{l}-0.039 \\
(0.032)\end{array}$ & $\begin{array}{c}-0.142^{* * *} \\
(0.055)\end{array}$ & $\begin{array}{l}-0.002 \\
(0.017)\end{array}$ \\
\hline Education: Tertiary & $\begin{array}{c}0.071 \\
(0.043)\end{array}$ & $\begin{array}{l}0.062^{* *} \\
(0.031)\end{array}$ & $\begin{array}{c}-0.081^{* *} \\
(0.037)\end{array}$ & $\begin{array}{c}-0.204^{* * *} \\
(0.059)\end{array}$ & $\begin{array}{c}-0.037^{* *} \\
(0.019)\end{array}$ \\
\hline Income group: Bottom 50\% & $\begin{array}{c}\text { (baseline) } \\
(.)\end{array}$ & $\begin{array}{c}\text { (baseline) } \\
(.)\end{array}$ & $\begin{array}{c}\text { (baseline) } \\
(.)\end{array}$ & $\begin{array}{c}\text { (baseline) } \\
(.)\end{array}$ & $\begin{array}{c}\text { (baseline) } \\
(.)\end{array}$ \\
\hline Income group: Middle $40 \%$ & $\begin{array}{l}-0.009 \\
(0.022)\end{array}$ & $\begin{array}{c}0.010 \\
(0.019)\end{array}$ & $\begin{array}{l}0.049^{* *} \\
(0.023)\end{array}$ & $\begin{array}{l}0.055^{\star *} \\
(0.026)\end{array}$ & $\begin{array}{l}0.024^{* *} \\
(0.011)\end{array}$ \\
\hline Income group: Top $10 \%$ & $\begin{array}{c}0.009 \\
(0.055)\end{array}$ & $\begin{array}{l}-0.009 \\
(0.035)\end{array}$ & $\begin{array}{l}-0.055 \\
(0.058)\end{array}$ & $\begin{array}{c}0.032 \\
(0.047)\end{array}$ & $\begin{array}{c}-0.004 \\
(0.025)\end{array}$ \\
\hline Employment status: Employed & $\begin{array}{c}\text { (baseline) } \\
(.)\end{array}$ & $\begin{array}{c}\text { (baseline) } \\
(.)\end{array}$ & $\begin{array}{c}\text { (baseline) } \\
\text { (.) }\end{array}$ & $\begin{array}{c}\text { (baseline) } \\
(.)\end{array}$ & $\begin{array}{c}\text { (baseline) } \\
(.)\end{array}$ \\
\hline Employment status: Unemployed & $\begin{array}{c}-0.035 \\
(0.035)\end{array}$ & $\begin{array}{c}-0.036 \\
(0.049)\end{array}$ & $\begin{array}{l}-0.050 \\
(0.091)\end{array}$ & $\begin{array}{c}0.004 \\
(0.171)\end{array}$ & $\begin{array}{c}-0.073^{\star * *} \\
(0.028)\end{array}$ \\
\hline Employment status: Inactive & $\begin{array}{l}-0.005 \\
(0.029)\end{array}$ & $\begin{array}{c}-0.003 \\
(0.022)\end{array}$ & $\begin{array}{c}0.098^{* * *} \\
(0.029)\end{array}$ & $\begin{array}{c}0.034 \\
(0.030)\end{array}$ & $\begin{array}{l}0.031^{* *} \\
(0.014)\end{array}$ \\
\hline
\end{tabular}




\begin{tabular}{|c|c|c|c|c|c|}
\hline Religion: None & (baseline) & (baseline) & (baseline) & (baseline) & (baseline) \\
\hline & $()$. & (.) & (.) & (.) & (.) \\
\hline Religion: Buddhist & 0.009 & $0.096^{\star * *}$ & $0.091^{* * *}$ & $0.142^{\star \star \star}$ & $0.102^{\star * \star}$ \\
\hline & $(0.027)$ & $(0.024)$ & $(0.029)$ & $(0.034)$ & $(0.014)$ \\
\hline Religion: Protestant & $\begin{array}{l}-0.072^{\star *} \\
(0.029)\end{array}$ & $\begin{array}{l}0.040 \\
(0.025)\end{array}$ & $\begin{array}{l}0.033 \\
(0.033)\end{array}$ & $\begin{array}{l}-0.034 \\
(0.031)\end{array}$ & $\begin{array}{l}0.007 \\
(0.015)\end{array}$ \\
\hline Religion: Catholic & -0.015 & 0.043 & -0.010 & $0.097^{*}$ & 0.031 \\
\hline 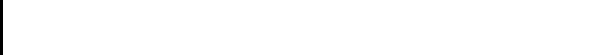 & $(0.045)$ & $(0.030)$ & $(0.039)$ & $(0.052)$ & $(0.020)$ \\
\hline Religion: Other & & $\begin{array}{c}0.064 \\
(0.092)\end{array}$ & $\begin{array}{l}-0.057 \\
(0.123)\end{array}$ & $\begin{array}{l}-0.208^{\star * *} \\
(0.072)\end{array}$ & $\begin{array}{l}-0.068 \\
(0.058)\end{array}$ \\
\hline Location: Rural & $-0.059^{*}$ & $-0.073^{\star *}$ & -0.005 & 0.032 & -0.018 \\
\hline Age: $20-40$ & $\begin{array}{c}\text { (baseline) } \\
(.)\end{array}$ & $\begin{array}{c}\text { (baseline) } \\
(.)\end{array}$ & $\begin{array}{c}\text { (baseline) } \\
\text { (.) }\end{array}$ & $\begin{array}{c}\text { (baseline) } \\
(.)\end{array}$ & $\begin{array}{c}\text { (baseline) } \\
(.)\end{array}$ \\
\hline Age: $40-60$ & $\begin{array}{l}-0.002 \\
(0.027)\end{array}$ & $\begin{array}{l}0.186^{* * *} \\
(0.025)\end{array}$ & $\begin{array}{c}0.017 \\
(0.035)\end{array}$ & $\begin{array}{l}0.140^{* * *} \\
(0.035)\end{array}$ & $\begin{array}{l}0.081^{* * *} \\
(0.015)\end{array}$ \\
\hline Age: $60+$ & $\begin{array}{c}0.040 \\
(0.039)\end{array}$ & $\begin{array}{c}0.384^{\star \star \star} \\
(0.039)\end{array}$ & $\begin{array}{c}0.002 \\
(0.046)\end{array}$ & $\begin{array}{l}0.273^{\star \star \star} \\
(0.044)\end{array}$ & $\begin{array}{l}0.184^{\star \star *} \\
(0.020)\end{array}$ \\
\hline Gender: Man & $\begin{array}{l}-0.039 \\
(0.025)\end{array}$ & $\begin{array}{l}-0.011 \\
(0.019)\end{array}$ & $\begin{array}{l}-0.005 \\
(0.025)\end{array}$ & $\begin{array}{l}-0.053^{* *} \\
(0.027)\end{array}$ & $\begin{array}{l}-0.016 \\
(0.012)\end{array}$ \\
\hline Marital status: Married / Partner & & $\begin{array}{l}0.046^{* *} \\
(0.023)\end{array}$ & $\begin{array}{l}0.081^{* *} \\
(0.032)\end{array}$ & $\begin{array}{c}0.035 \\
(0.037)\end{array}$ & $\begin{array}{l}0.036^{* * *} \\
(0.013)\end{array}$ \\
\hline Union membership: Yes & $\begin{array}{l}0.128^{\star *} \\
(0.051)\end{array}$ & $\begin{array}{l}-0.042 \\
(0.042)\end{array}$ & $\begin{array}{l}-0.153^{* * *} \\
(0.041)\end{array}$ & & $\begin{array}{l}-0.038 \\
(0.026)\end{array}$ \\
\hline Constant & $\begin{array}{l}0.084^{*} \\
(0.044)\end{array}$ & $\begin{array}{l}-0.079^{*} \\
(0.045)\end{array}$ & $\begin{array}{l}0.244^{* * *} \\
(0.056)\end{array}$ & $\begin{array}{l}0.335^{\star \star \star} \\
(0.071)\end{array}$ & $\begin{array}{l}0.096^{\star * *} \\
(0.025)\end{array}$ \\
\hline $\begin{array}{l}\text { R-squared } \\
{ }^{*} p<0.10,{ }^{* *} p<0.05,{ }^{* * *} p<0.01\end{array}$ & 0.28 & 0.20 & 0.22 & 0.21 & 0.18 \\
\hline $\begin{array}{l}\text { Source: authors' computations } \\
\text { Note: the table shows the result } \\
\text { year, and over the entire period }\end{array}$ & political & s surveys. & $\begin{array}{l}\text { ts of sup } \\
\text { s not ava }\end{array}$ & the Hanna & nuri Party by \\
\hline
\end{tabular}


Figure B1 - Presidential election results in Taiwan, 1996-2020

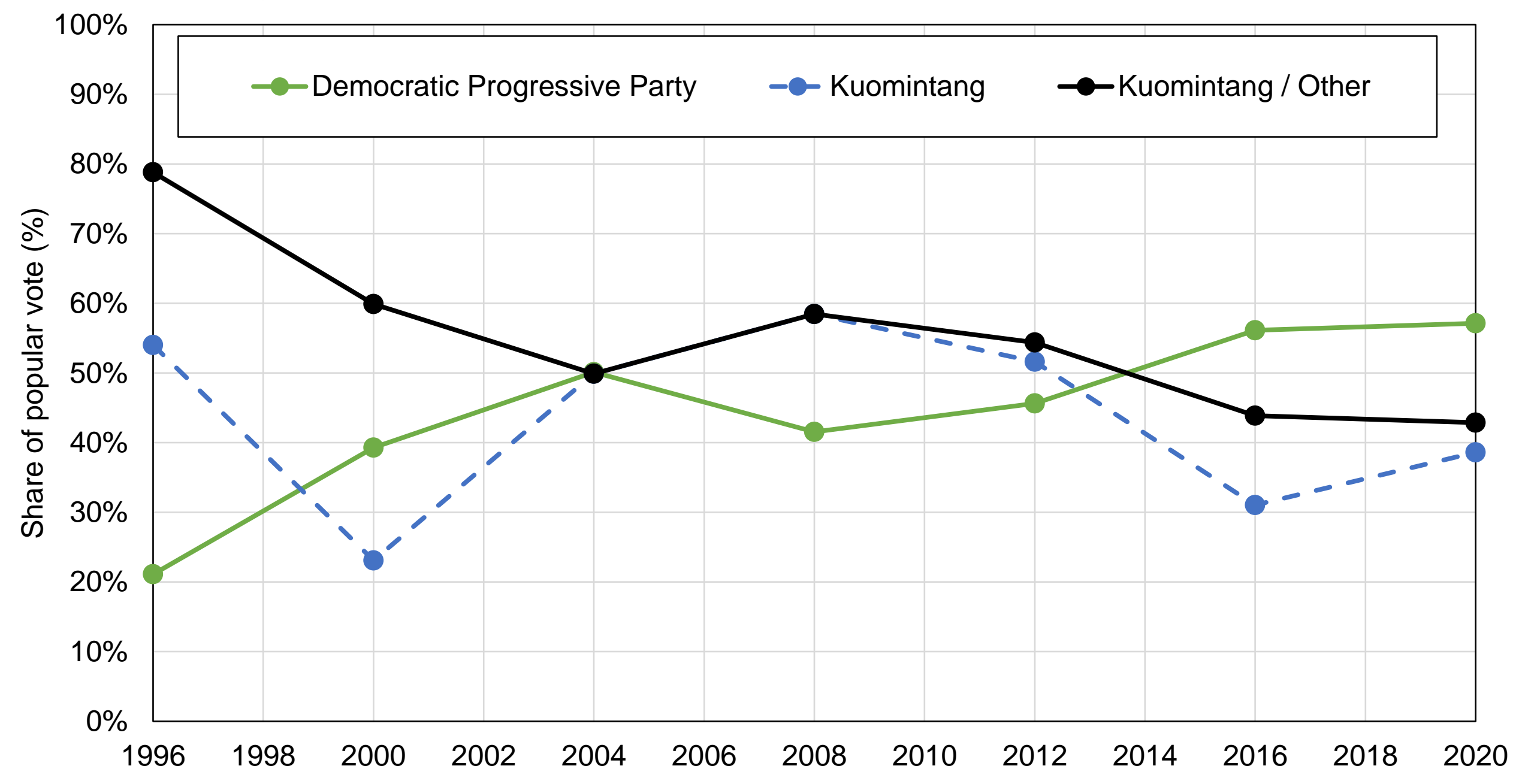

Source: authors' computations using official election results.

Note: the figure shows the share of votes received by selected groups of Taiwanese political parties in presidential elections between 1996 and 2020. 


\section{Figure B2 - Vote for DPP by ethnicity}

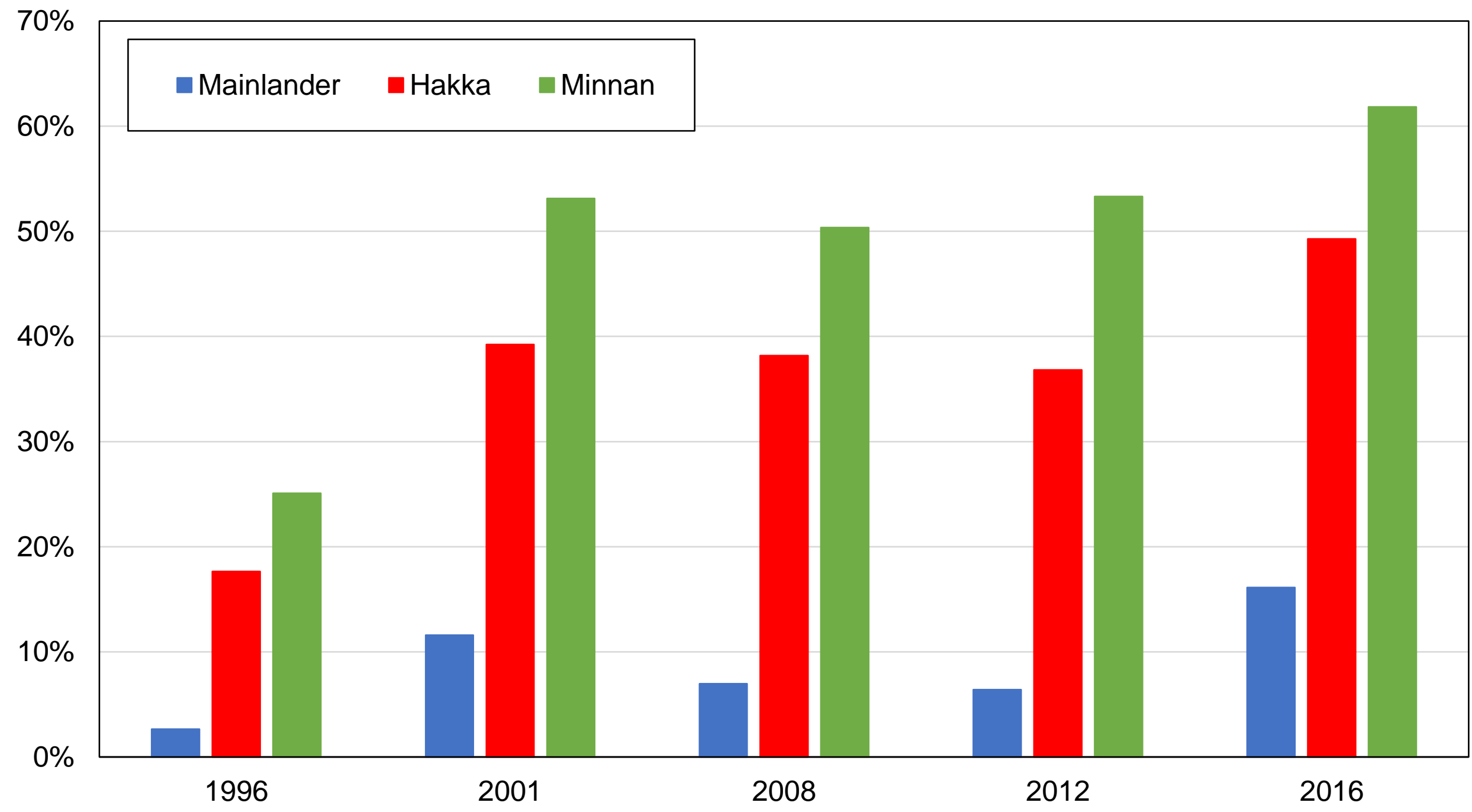

Source: authors' computations using Taiwanese political attitudes surveys. Note: the figure shows the share of votes received by the DPP by ethnicity. 


\section{Figure B3 - The ethnic cleavage in Taiwan}

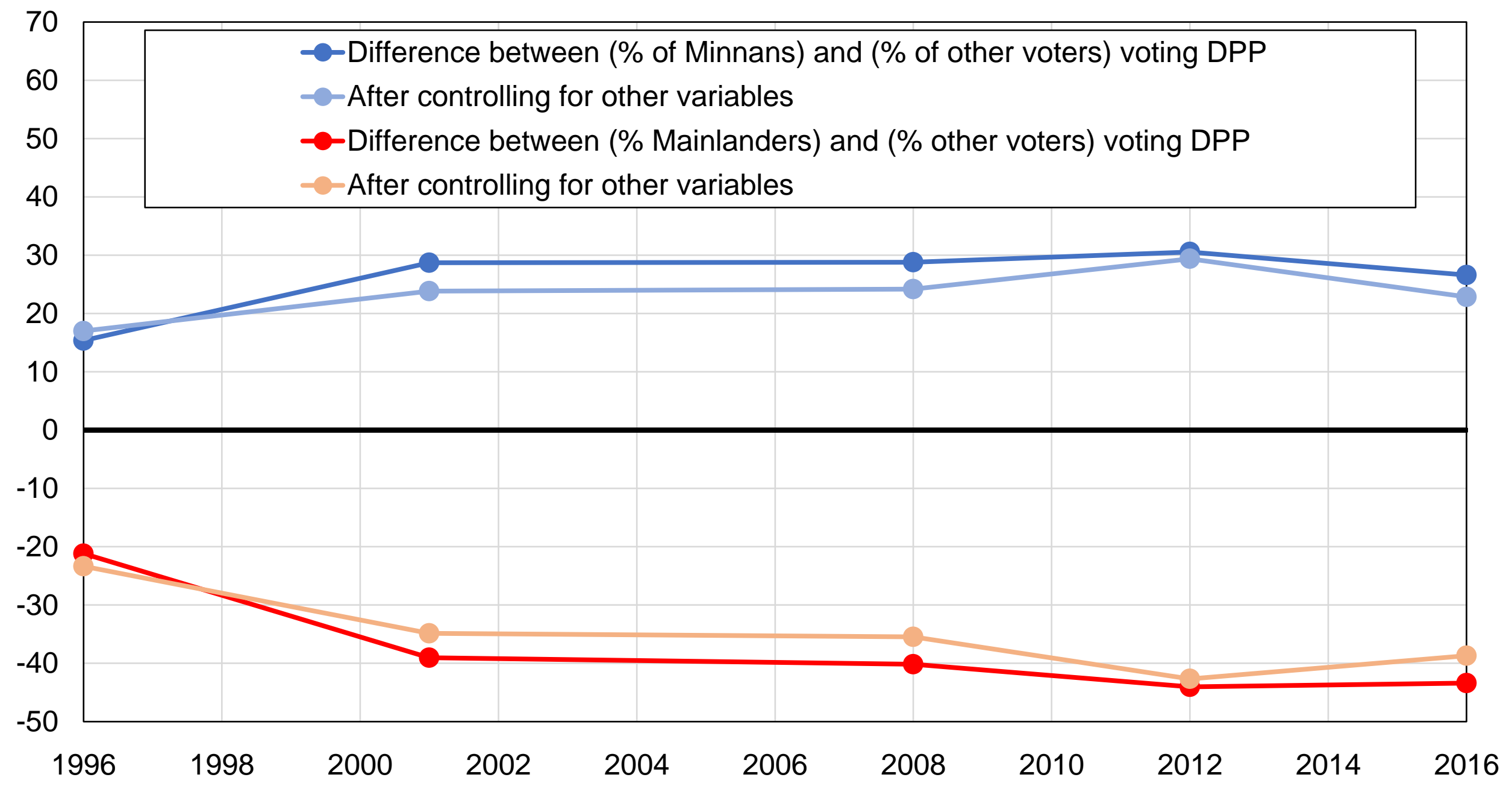

Source: authors' computations using Taiwanese political attitudes surveys.

Note: the figure shows the relative support towards the DPP among Minnans and Mainlanders, before and after controlling for income, education, age, gender, employment, marital status, union membership, religion, and region of residence. 


\section{Figure B4 - The regional cleavage in Taiwan}

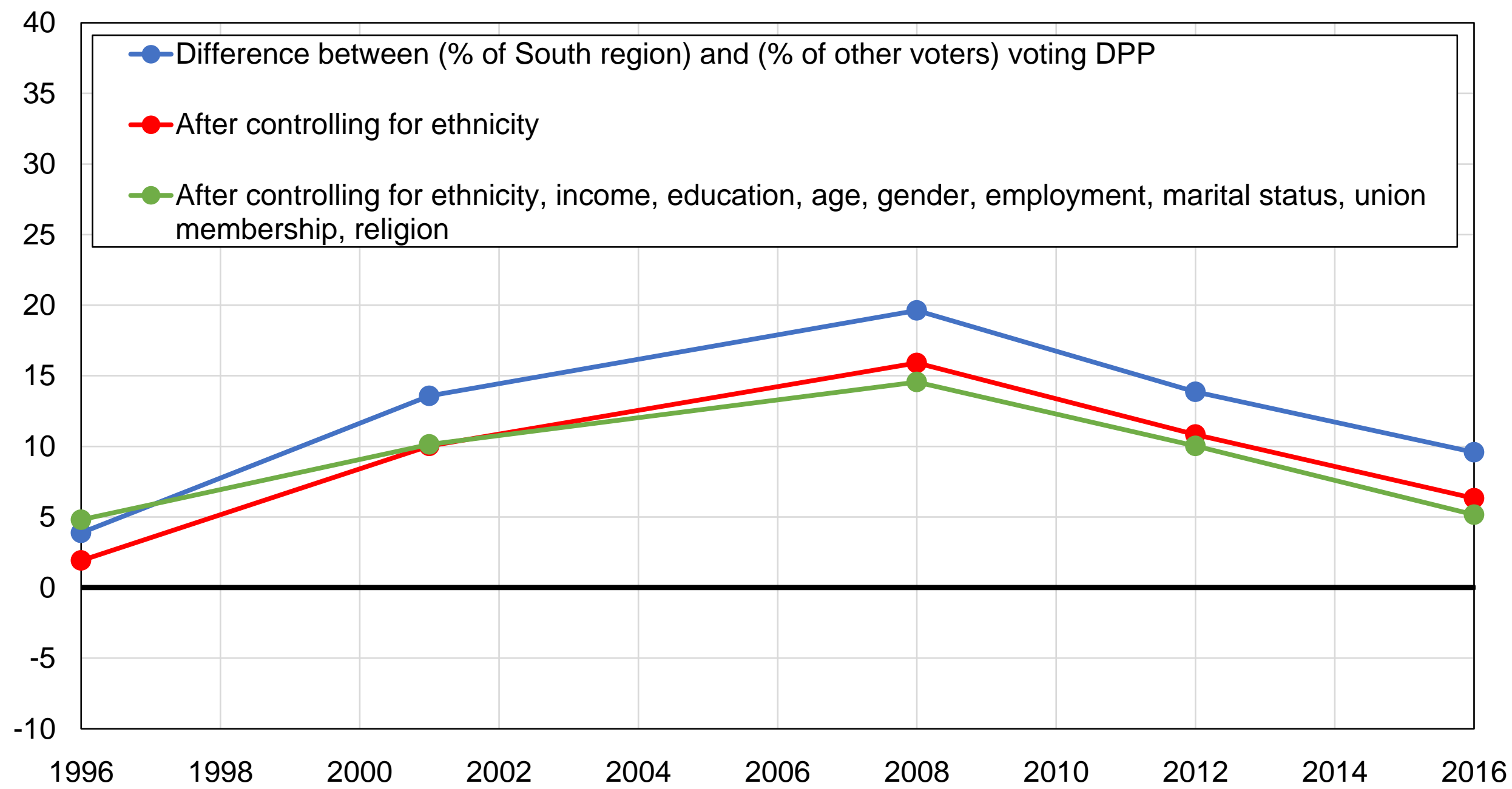

Source: authors' computations using Taiwanese political attitudes surveys.

Note: the figure shows the difference between the share of voters living the Southern region and the share of other voters voting for the DPP, before and after controlling for other variables. 


\section{Figure B5 - Vote for DPP among low-income and lower-educated voters}

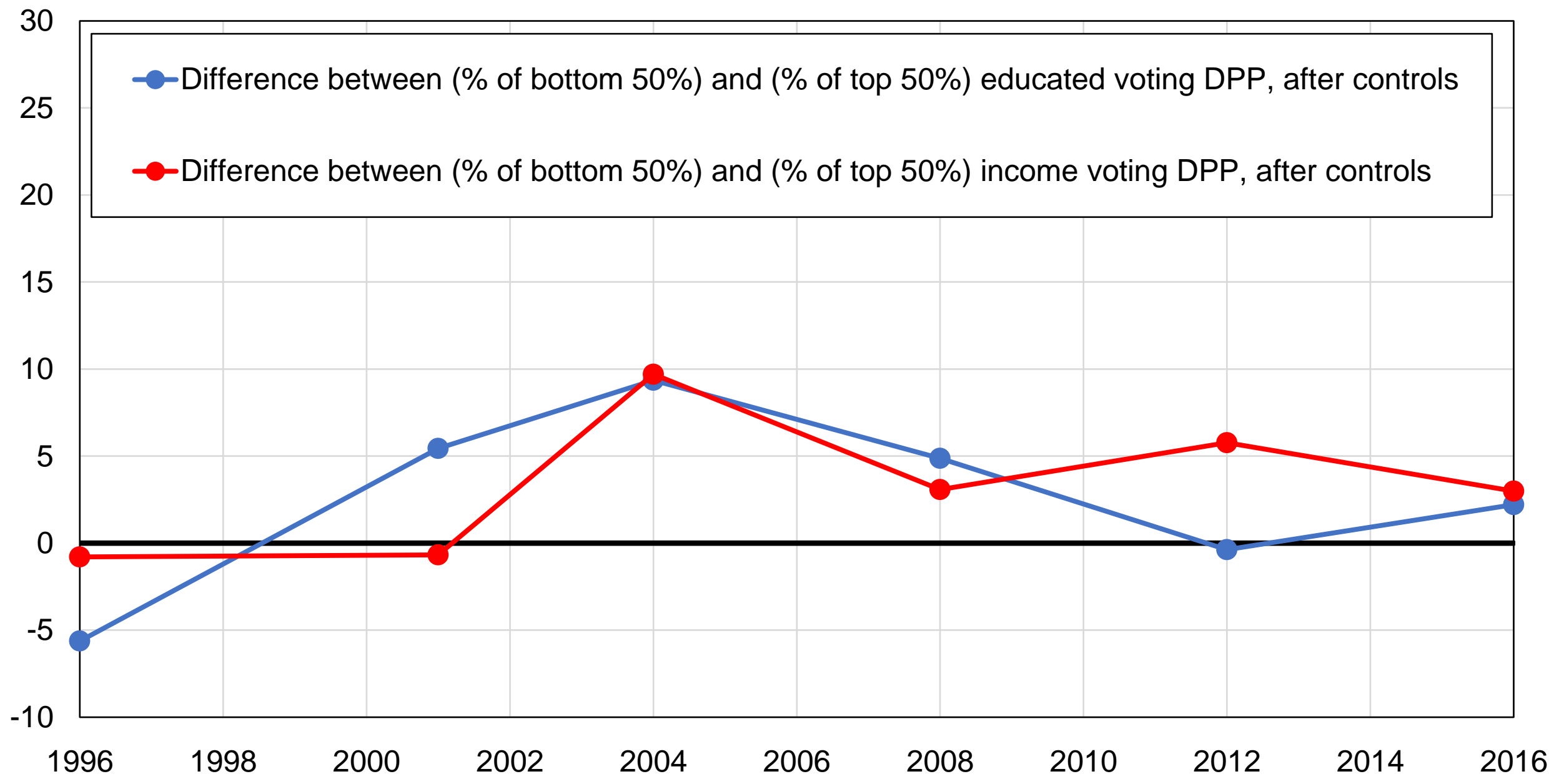

Source: authors' computations using Taiwanese political attitudes surveys.

Note: the figure shows the relative support of low-income and low-educated voters towards the DPP, after controlling for income/education, ethnicity, age, gender, occupation, marital status, union membership, religion, and region. 


\section{Figure B6 - Legislative election results in Taiwan by coalition}

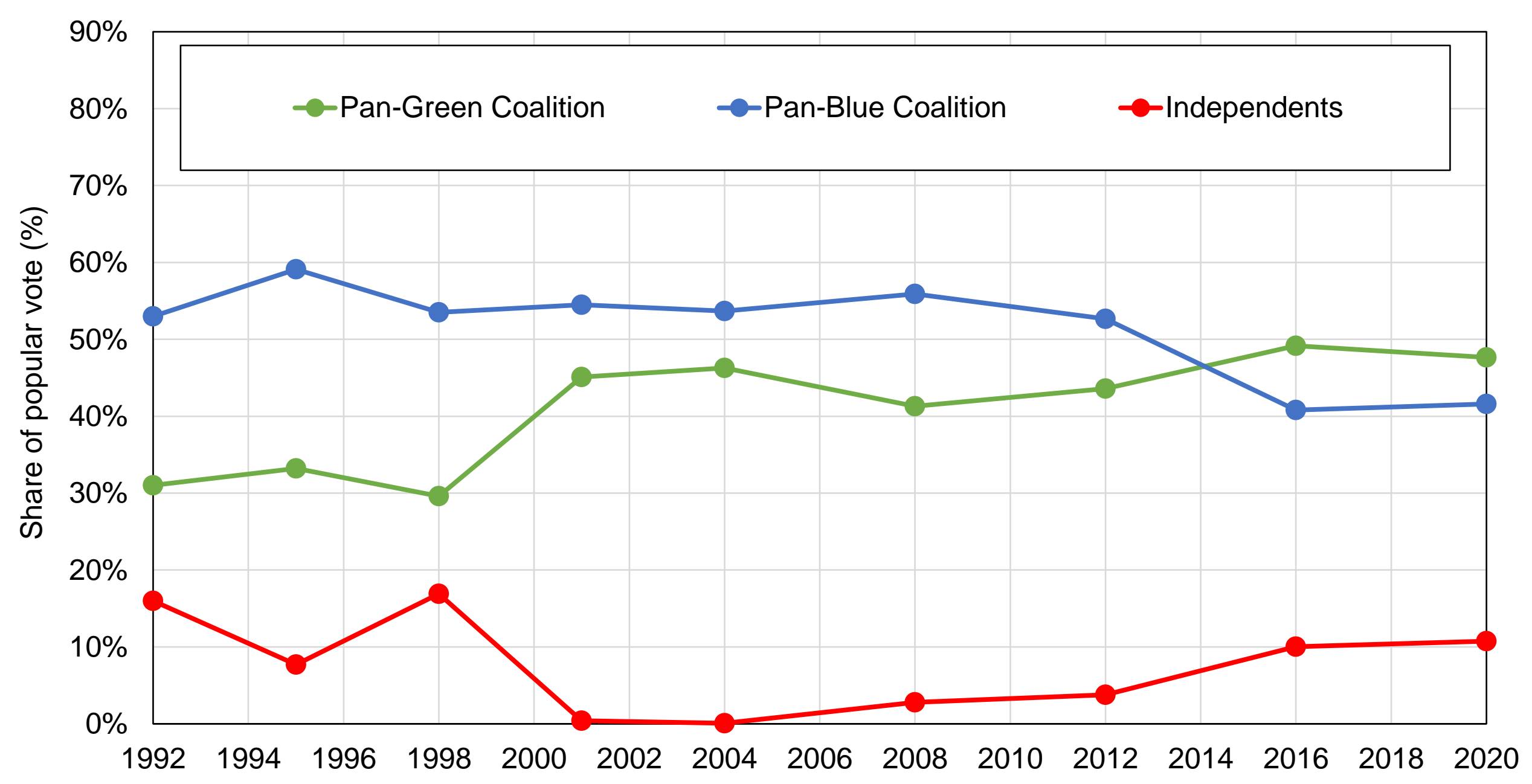

Source: authors' computations using official election results.

Note: the figure shows the share of votes received by selected groups of Taiwanese political parties in legislative elections between 1992 and 2020. 
Figure B7 - Detailed legislative election results, 1992-2020

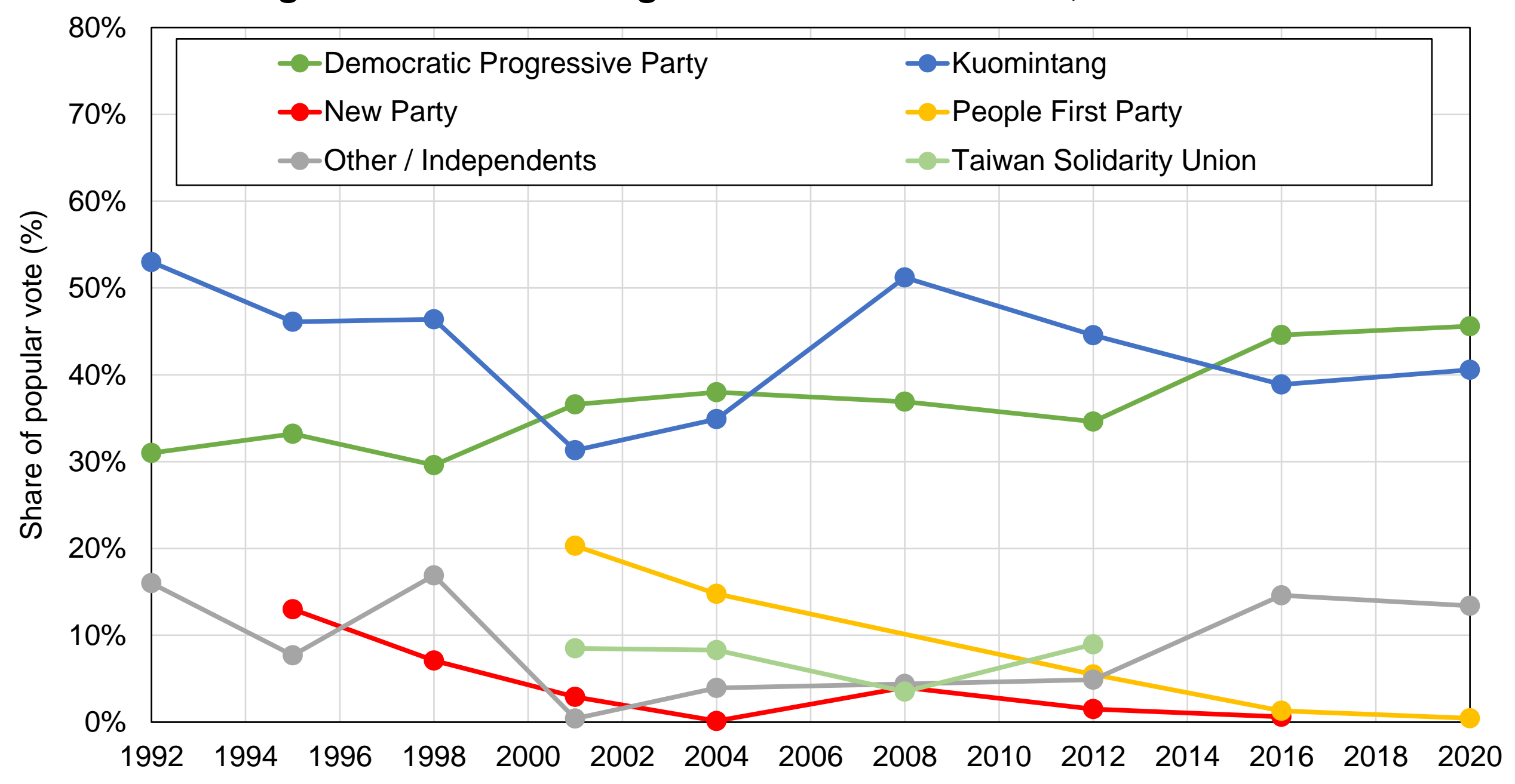

Source: authors' computations using official election results.

Note: the figure shows the share of votes received by selected groups of Taiwanese political parties in legislative elections between 1992 and 2020. 


\section{Figure B8 - Detailed presidential election results, 1996-2020}

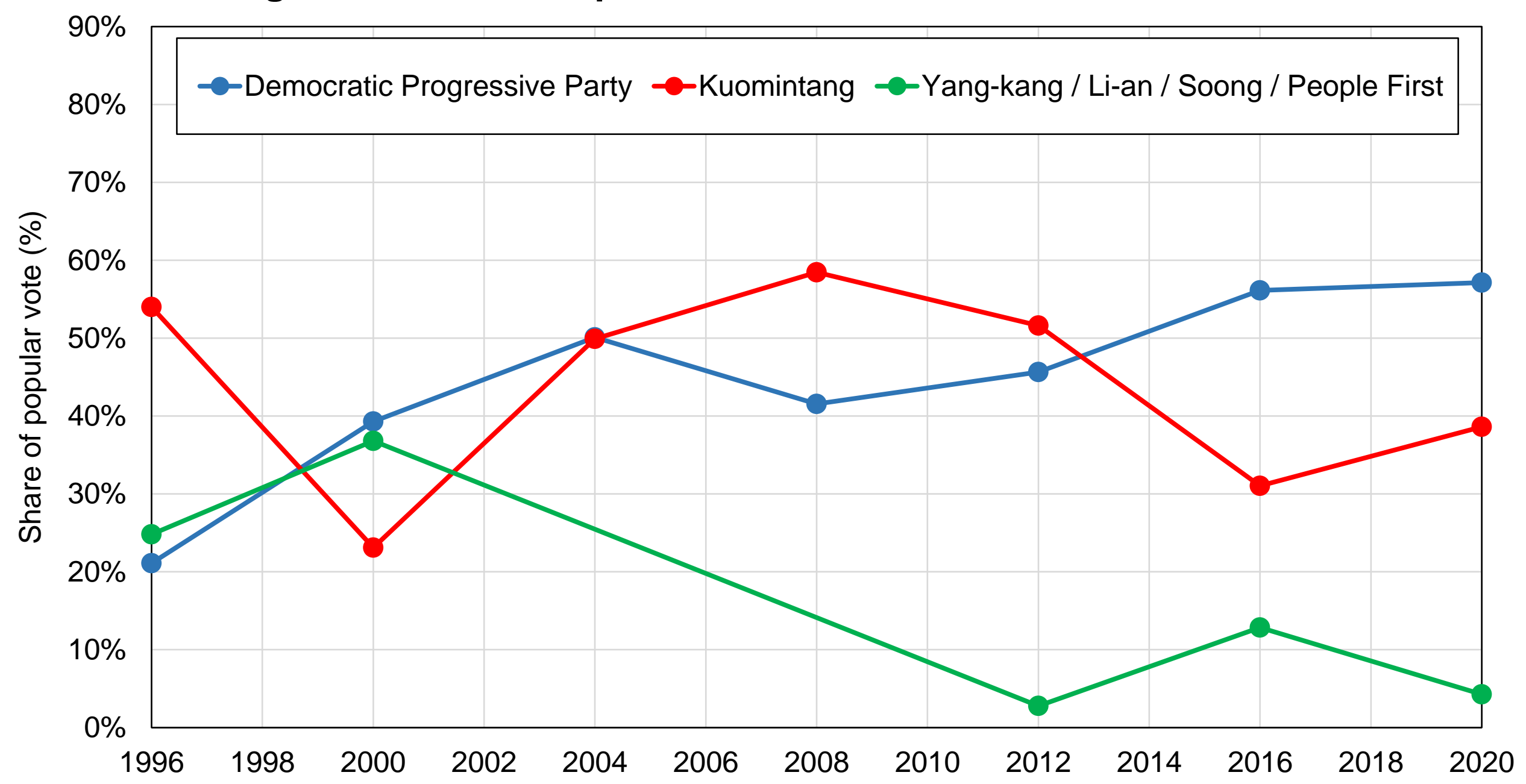

Source: authors' computations using official election results.

Note: the figure shows the share of votes received by selected groups of Taiwanese political parties in presidential elections between 1996 and 2020. 
Figure B9 - The composition of the electorate by education level

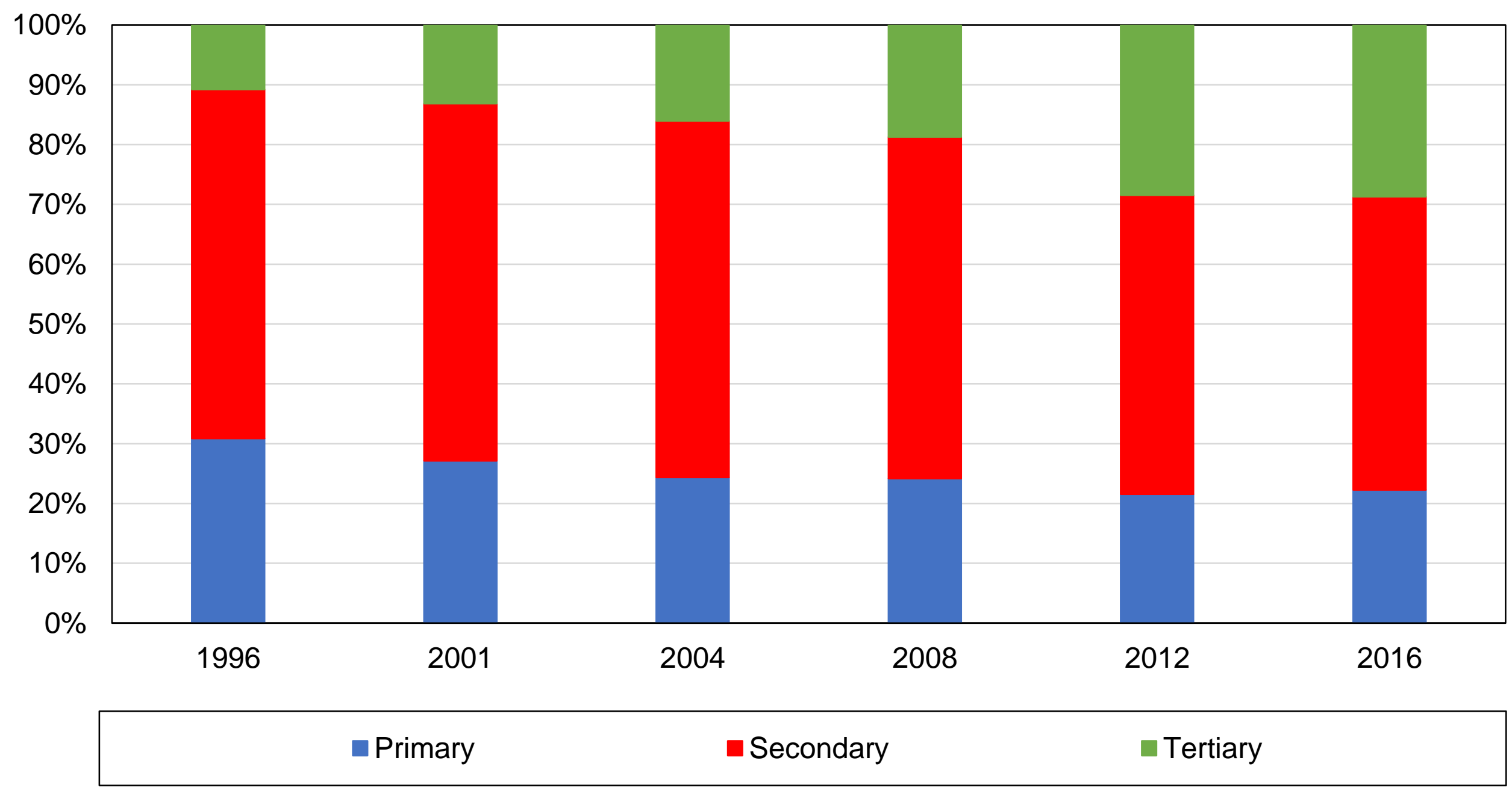

Source: authors' computations using Taiwanese political attitudes surveys.

Note: the figure shows the composition of the electorate by education level. 
Figure B10 - The composition of the electorate by age group

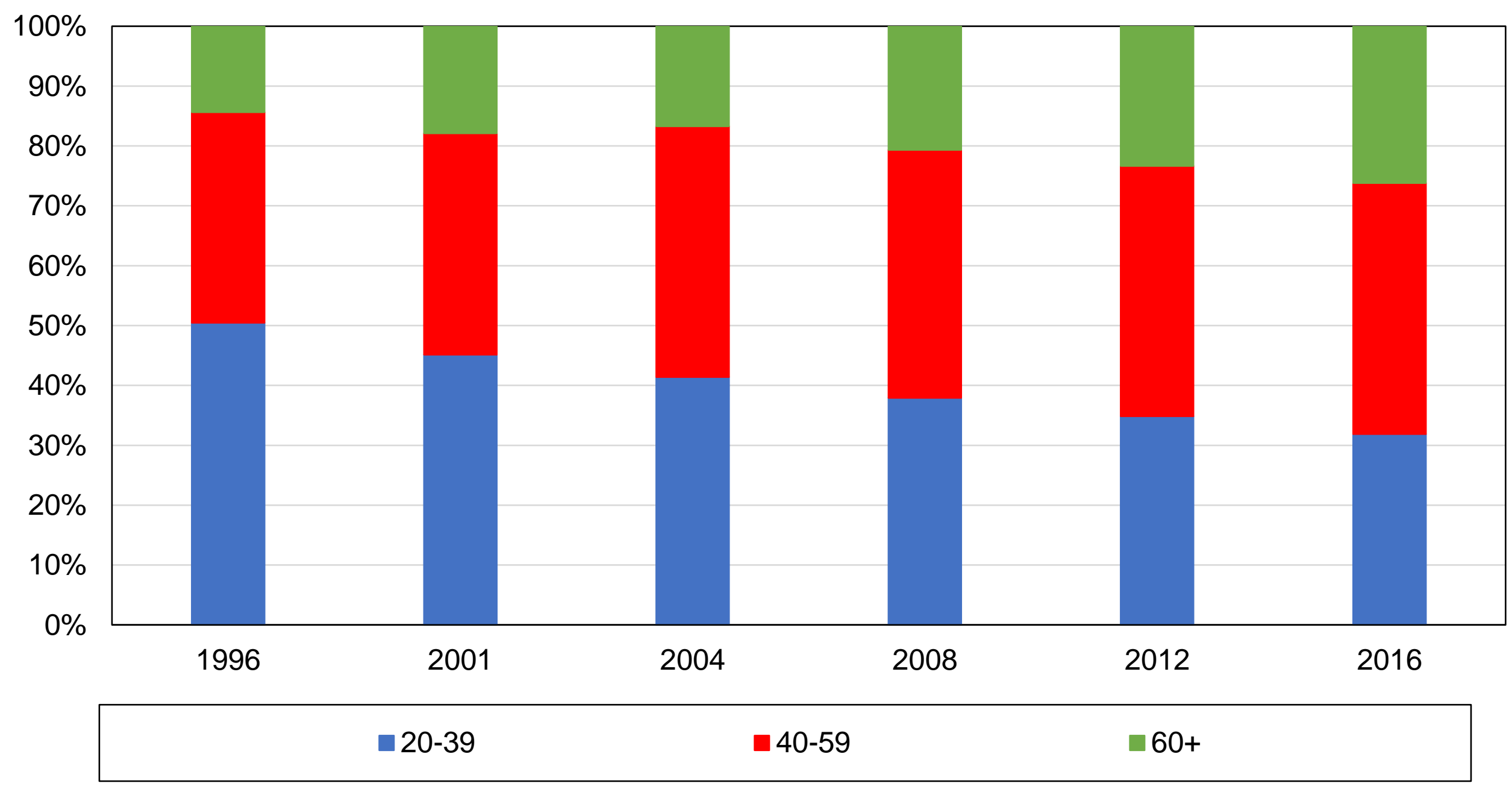

Source: authors' computations using Taiwanese political attitudes surveys. Note: the figure shows the composition of the electorate by age group. 
Figure B11 - The composition of the electorate by ethnolinguistic group

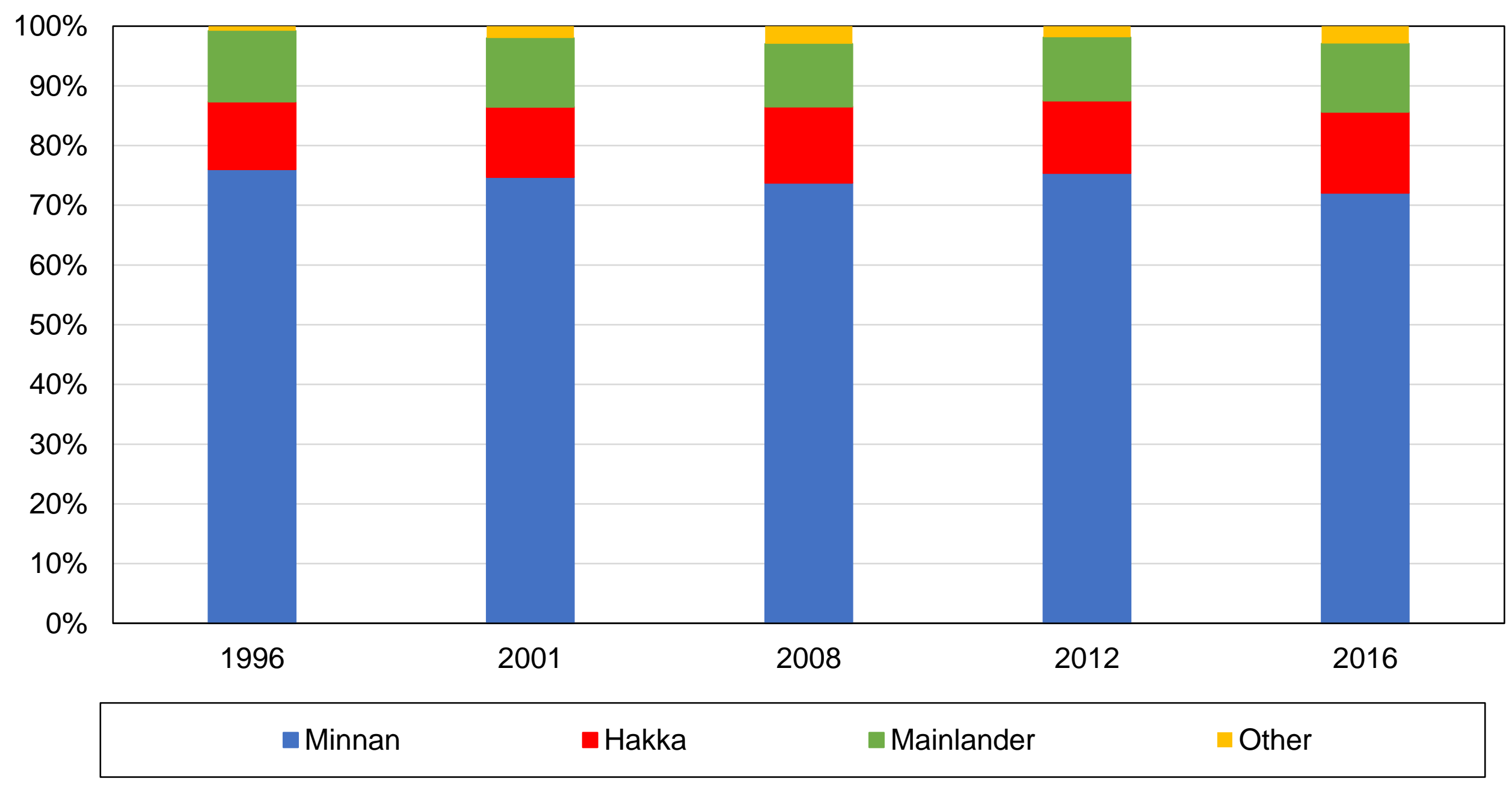

Source: authors' computations using Taiwanese political attitudes surveys.

Note: the figure shows the composition of the electorate by ethnolinguistic group. 
Figure B12 - The composition of the electorate by region

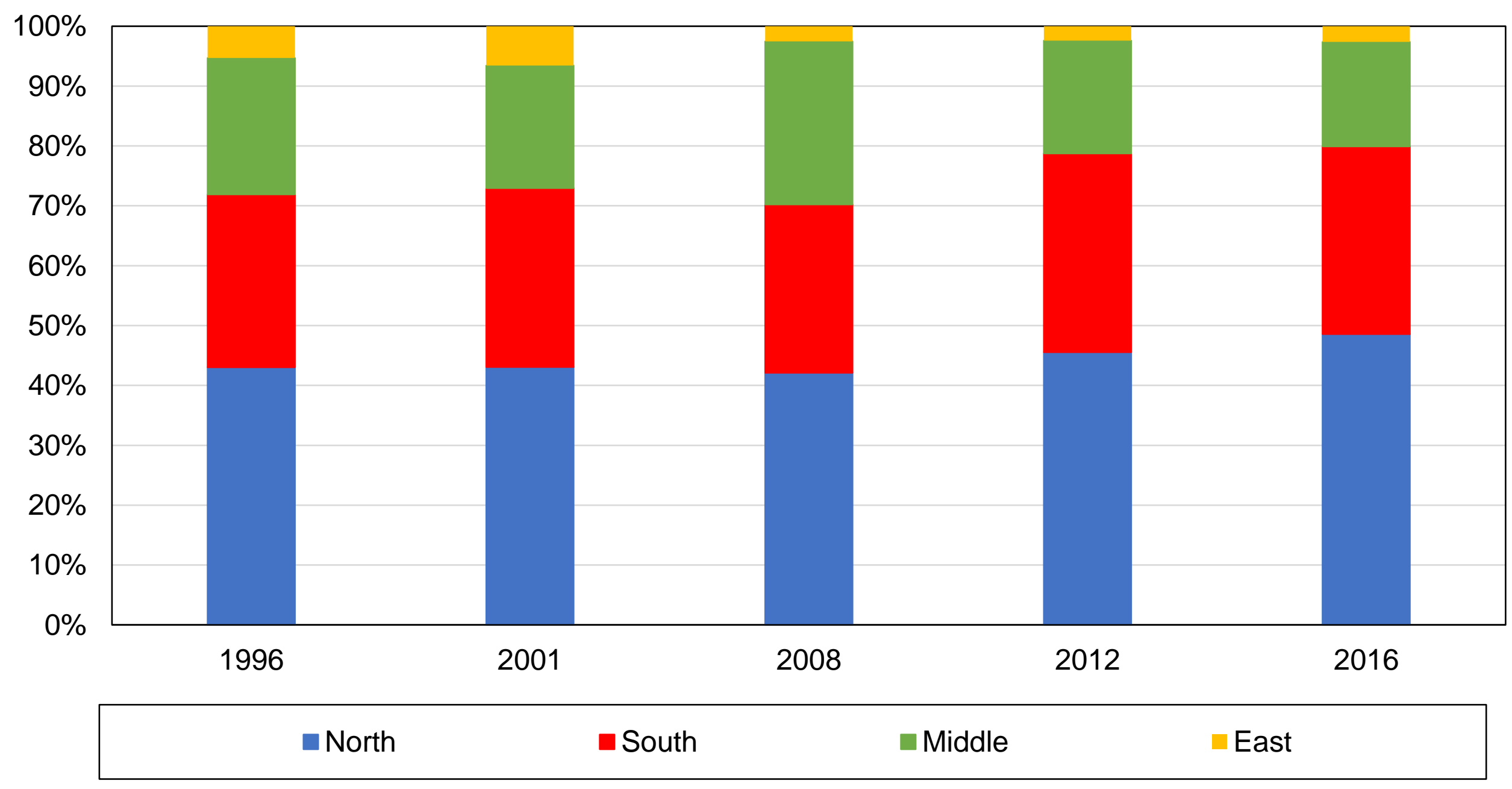

Source: authors' computations using Taiwanese political attitudes surveys. Note: the figure shows the composition of the electorate by region. 
Figure B13 - Composition of regions by ethnolinguistic group, 1996

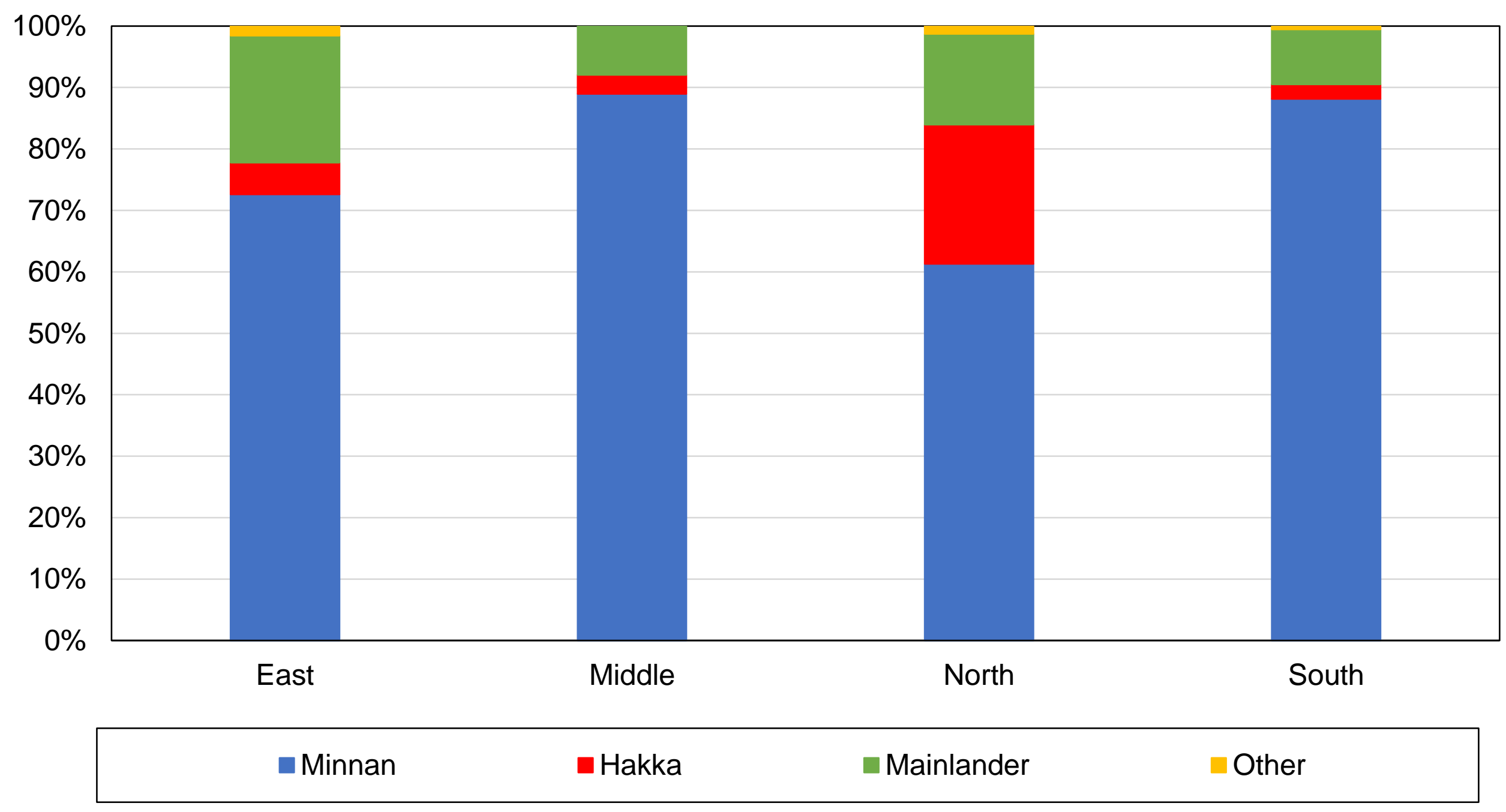

Source: authors' computations using Taiwanese political attitudes surveys.

Note: the figure shows the composition of regions by ethnolinguistic group in 1996 . 
Figure B14 - Composition of regions by ethnolinguistic group, 2016

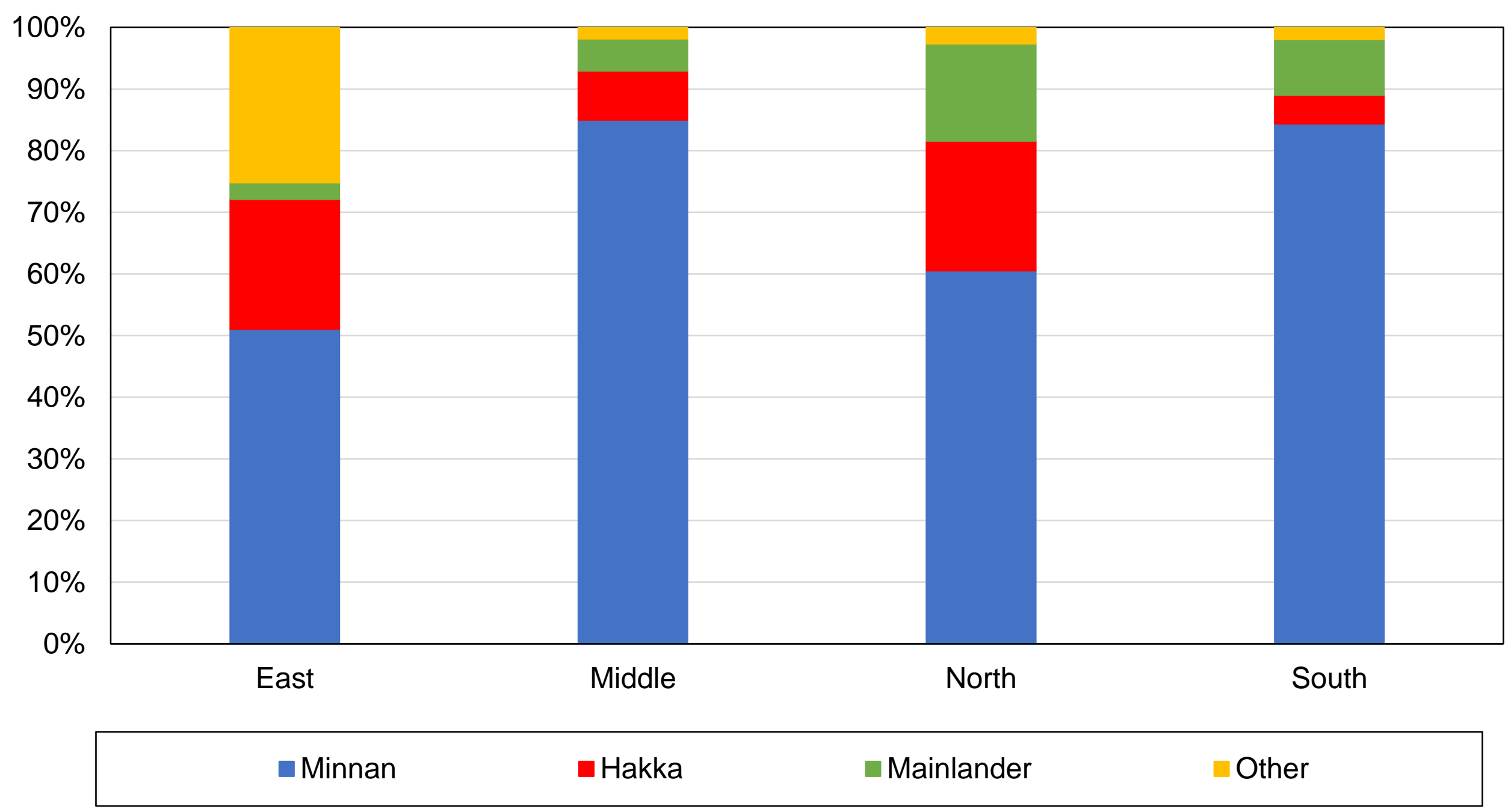

Source: authors' computations using Taiwanese political attitudes surveys.

Note: the figure shows the composition of regions by ethnolinguistic group in 2016 . 
Figure B15 - Composition of income quintiles by education level, 1996

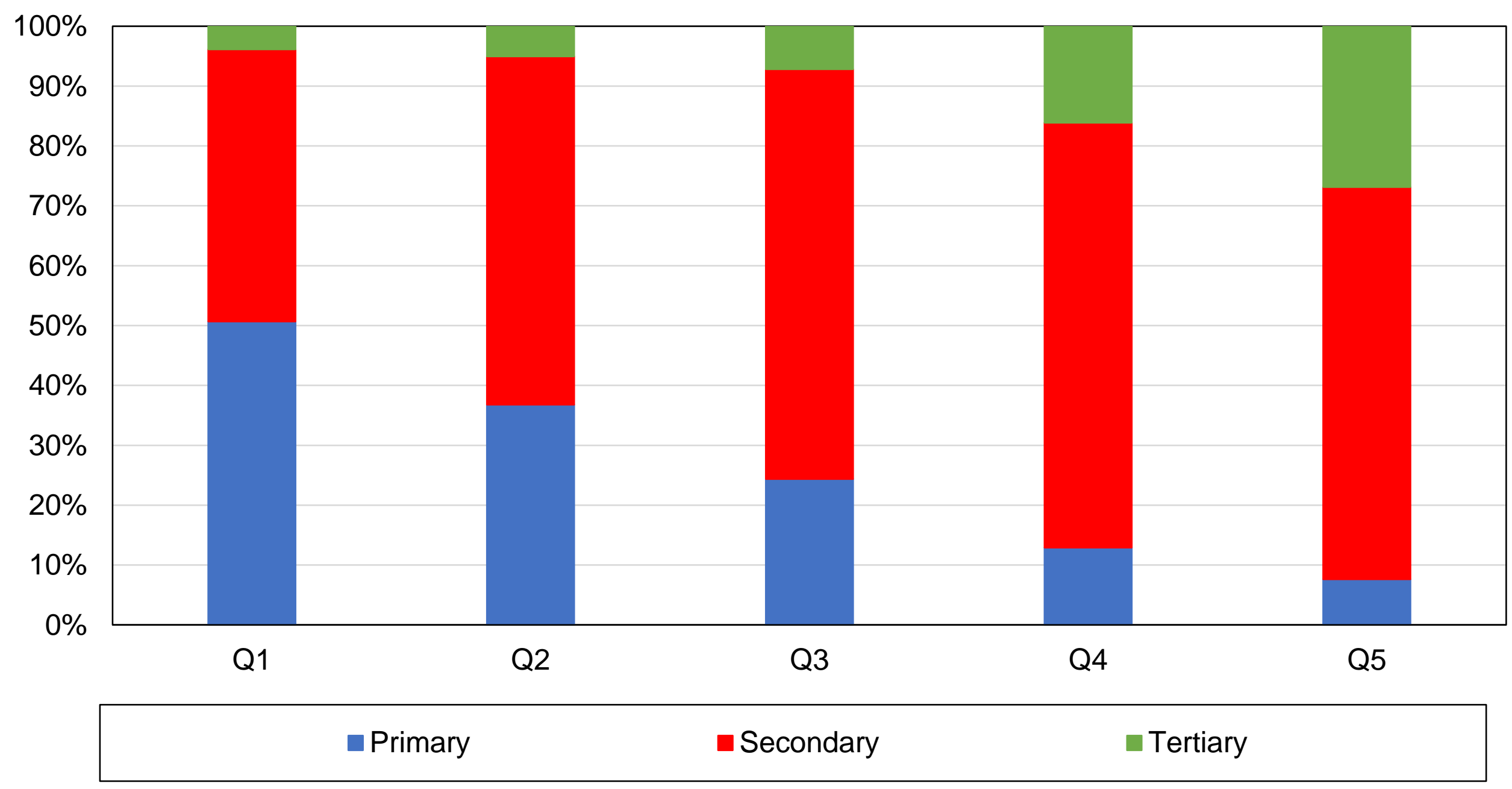

Source: authors' computations using Taiwanese political attitudes surveys.

Note: the figure shows the composition of income quintiles by education level in 1996. 
Figure B16 - Composition of income quintiles by education level, 2016

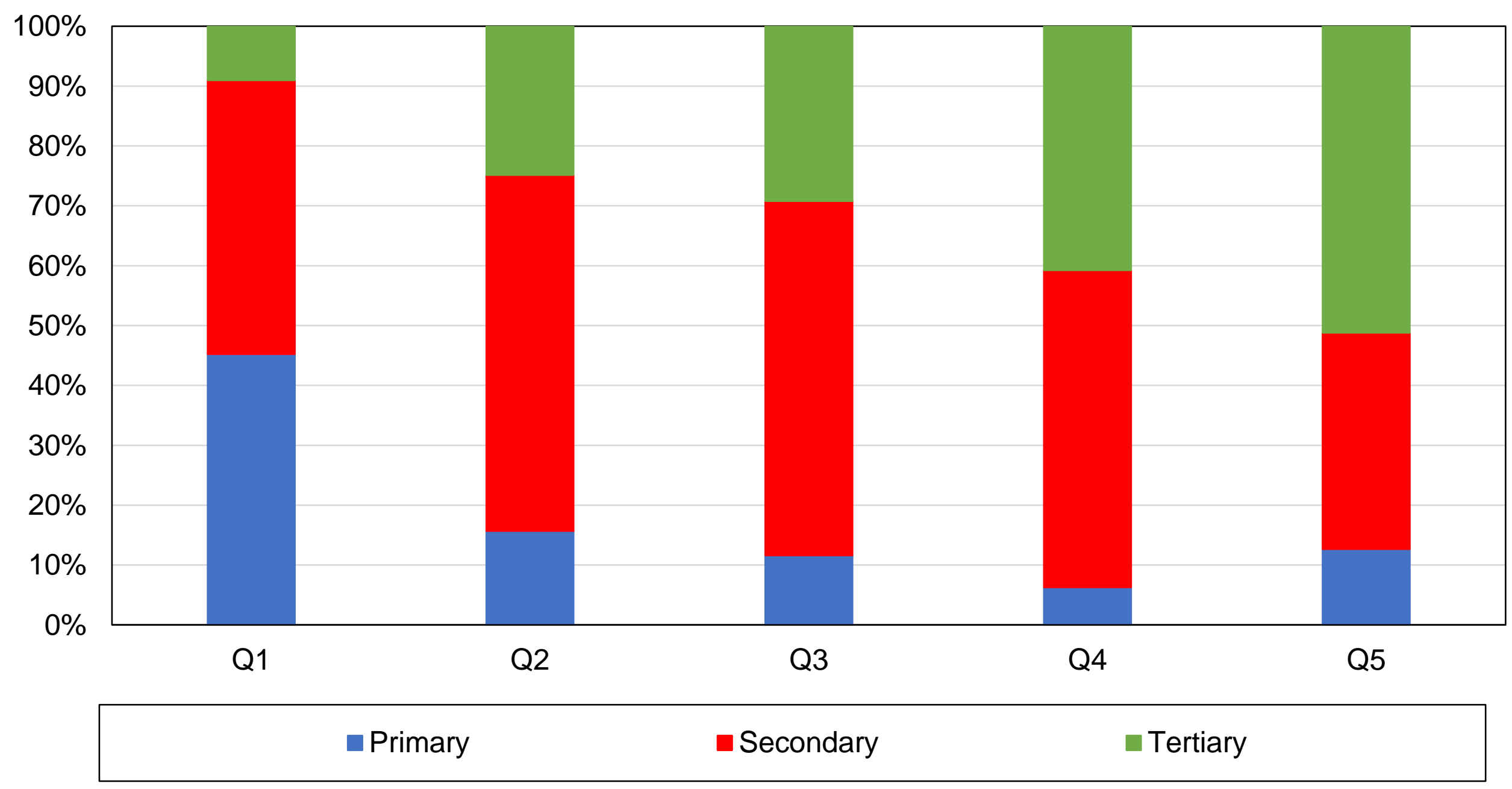

Source: authors' computations using Taiwanese political attitudes surveys.

Note: the figure shows the composition of income quintiles by education level in 2016 . 
Figure B17 - Composition of income quintiles by ethnolinguistic affiliation, 1996

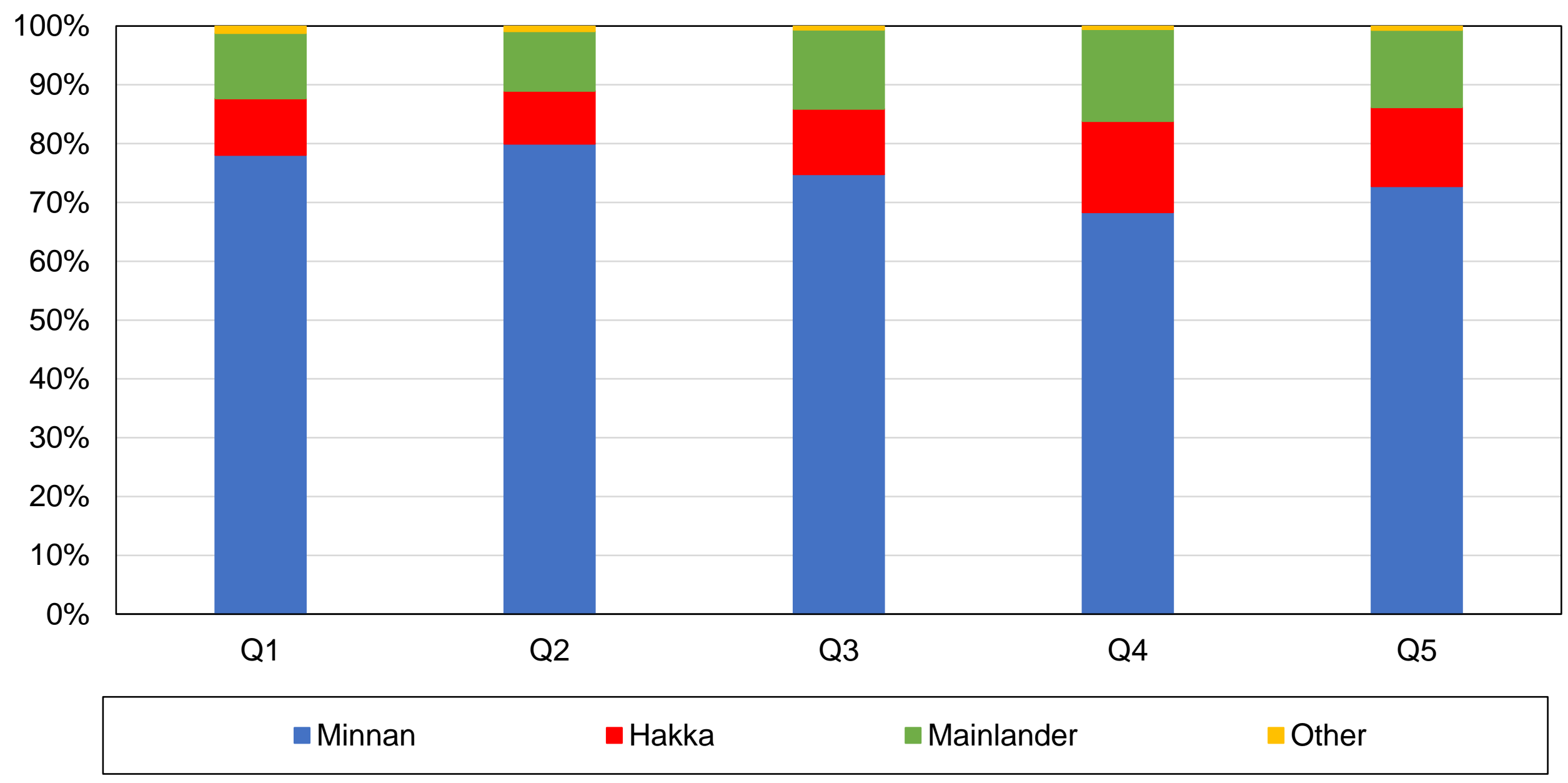

Source: authors' computations using Taiwanese political attitudes surveys.

Note: the figure shows the composition of income quintiles by ethnolinguistic group in 1996. 
Figure B17b - Composition of ethnic groups by income quintile/decile, 1996

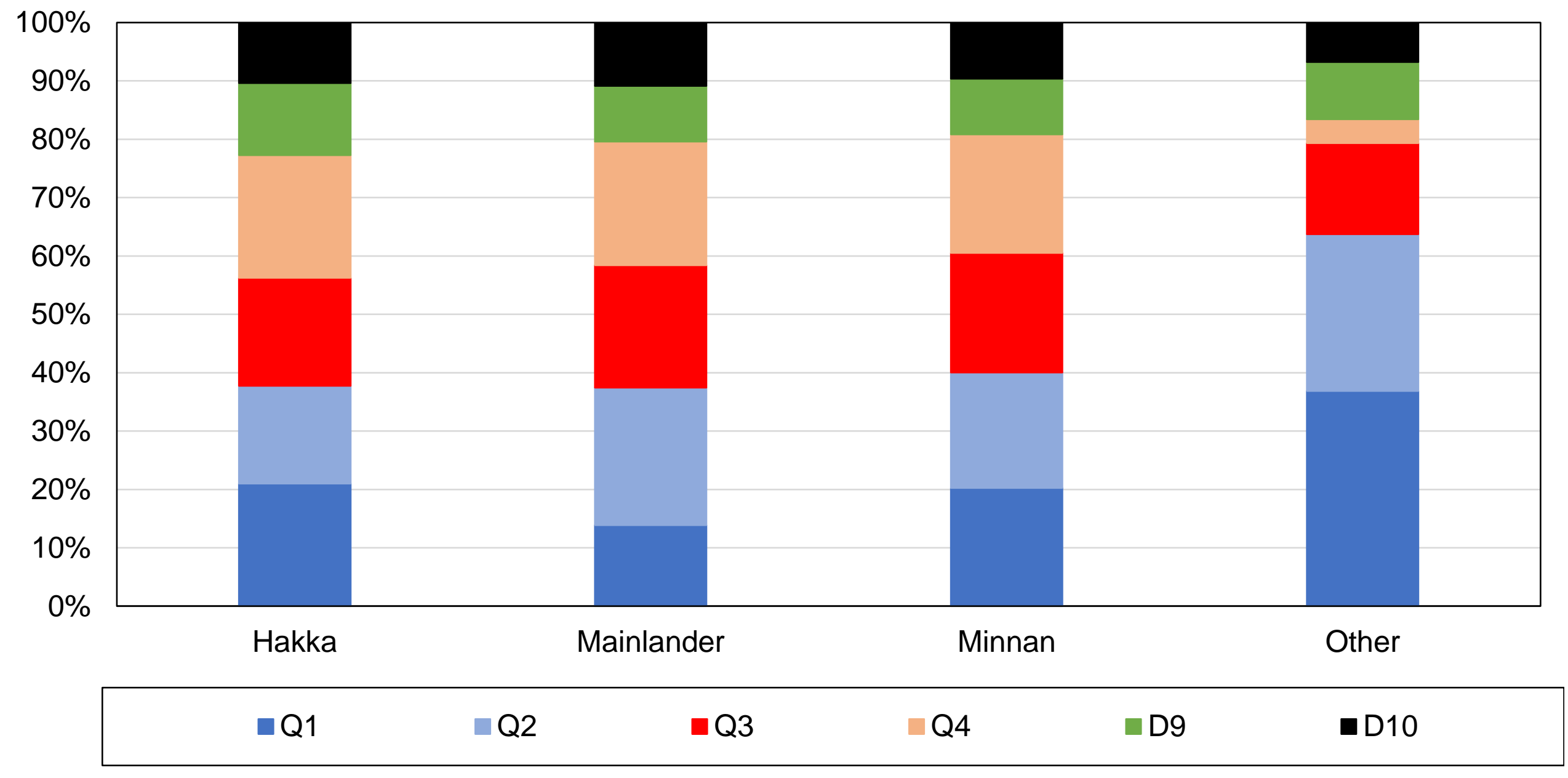

Source: authors' computations using Taiwanese political attitudes surveys.

Note: the figure shows the composition of ethnolinguistic groups by income in 1996. 
Figure B18 - Composition of income quintiles by ethnolinguistic affiliation, 2016

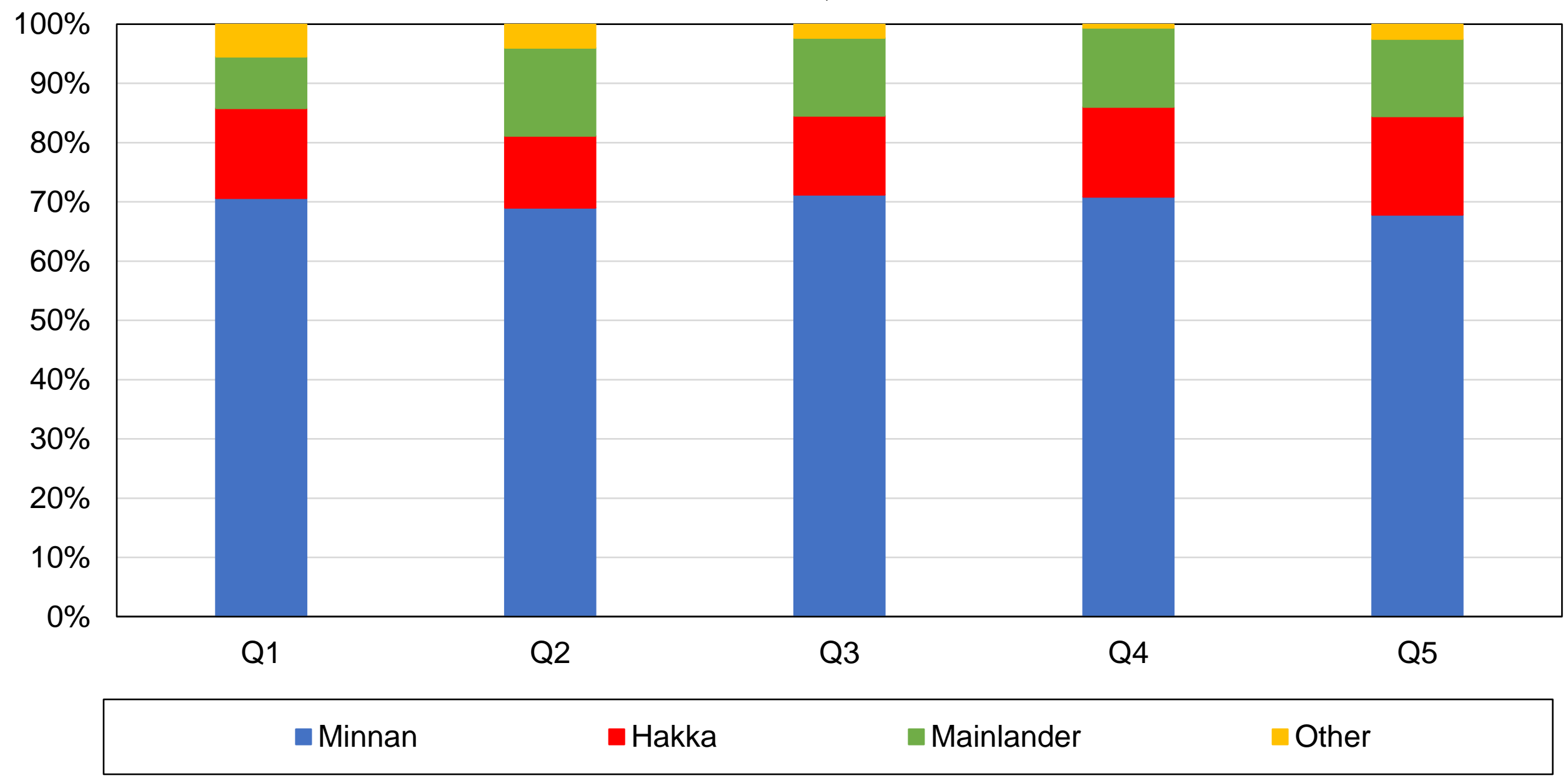

Source: authors' computations using Taiwanese political attitudes surveys.

Note: the figure shows the composition of income quintiles by ethnolinguistic group in 2016 . 
Figure B18 - Composition of ethnic groups by income quintile/decile, 2016

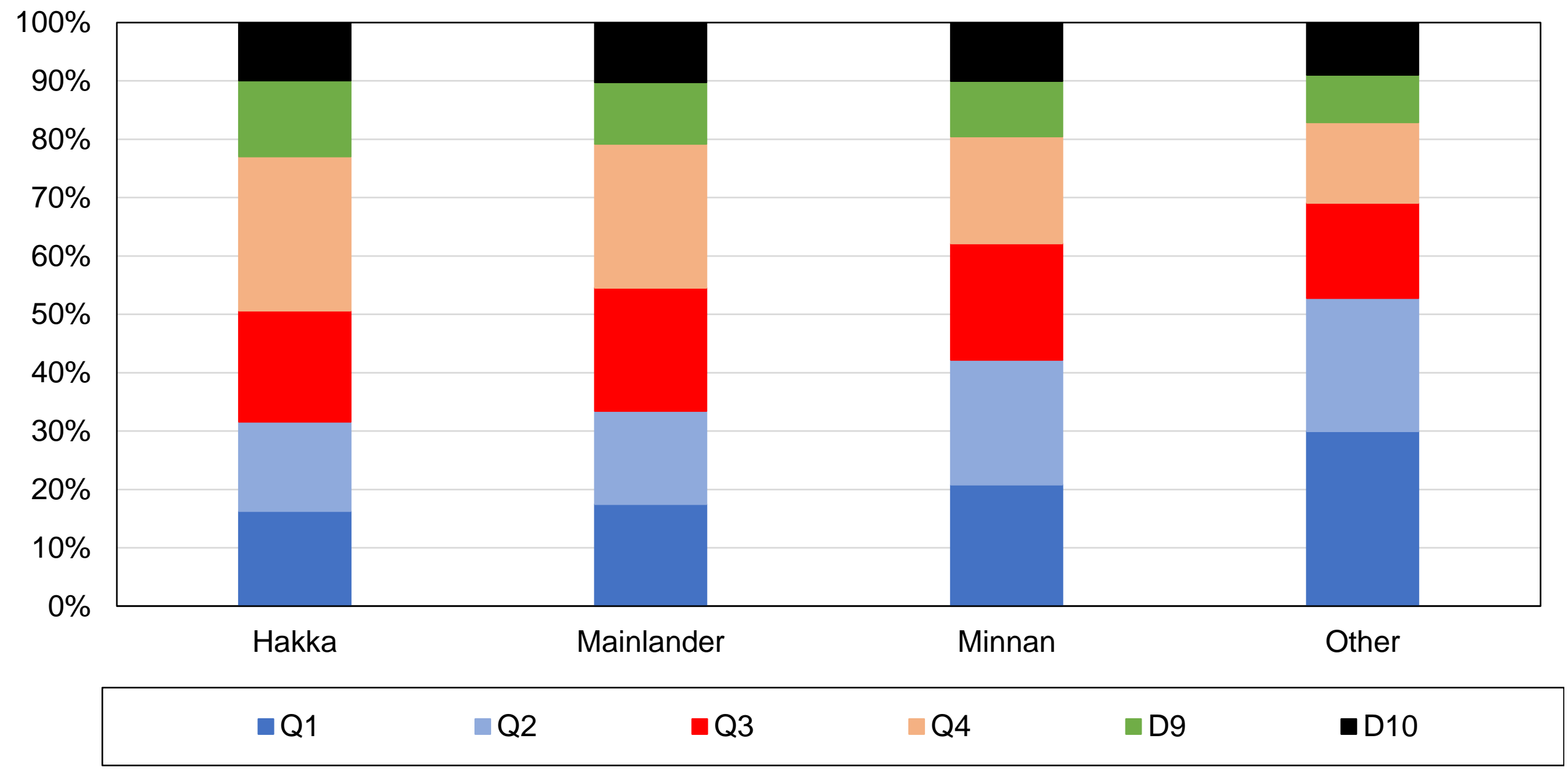

Source: authors' computations using Taiwanese political attitudes surveys.

Note: the figure shows the composition of ethnolinguistic groups by income in 2016. 
Figure B19 - Composition of income quintiles by region, 1996

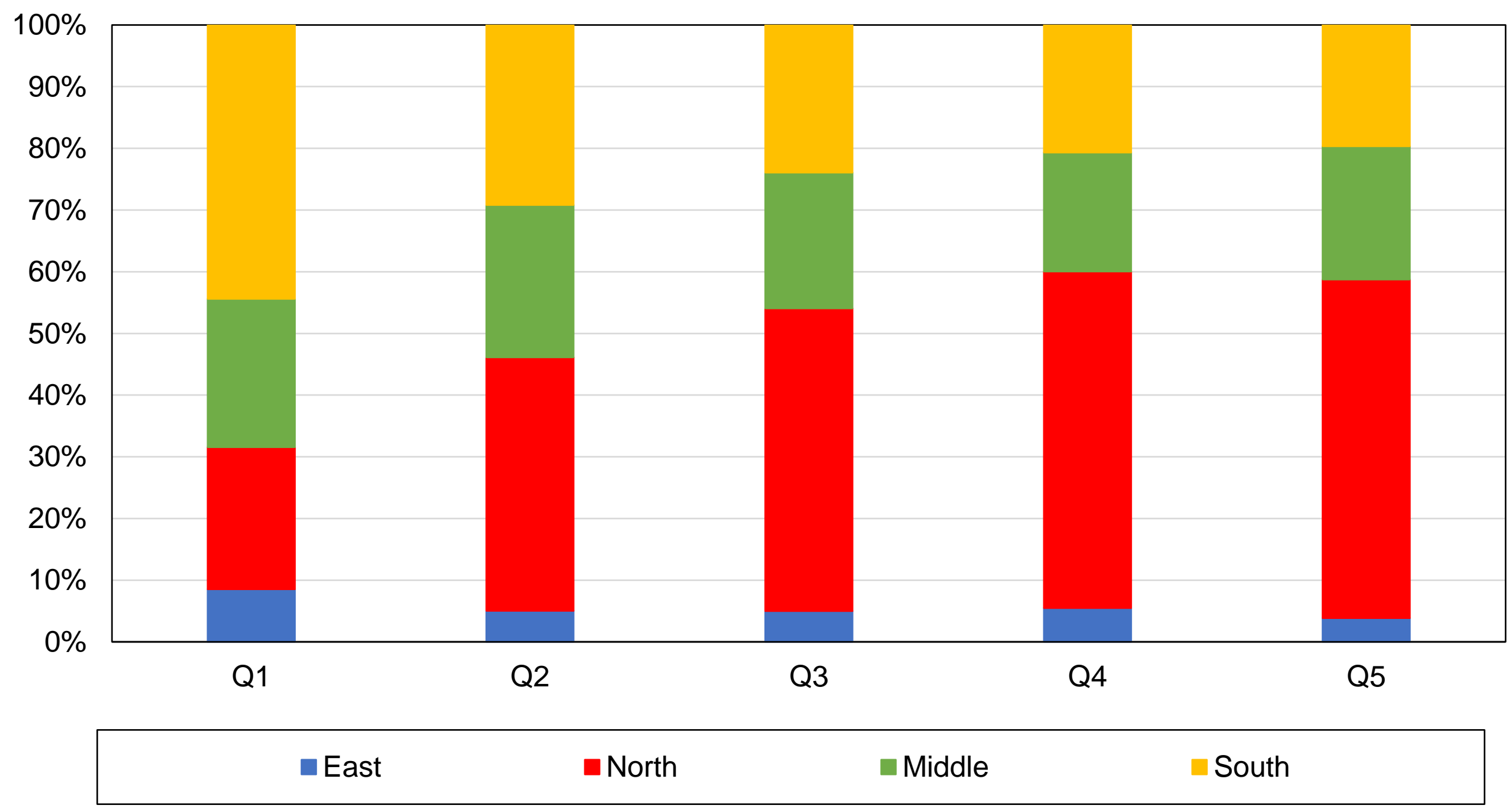

Source: authors' computations using Taiwanese political attitudes surveys. Note: the figure shows the composition of income quintiles by region in 1996 . 
Figure B20 - Composition of income quintiles by region, 2016

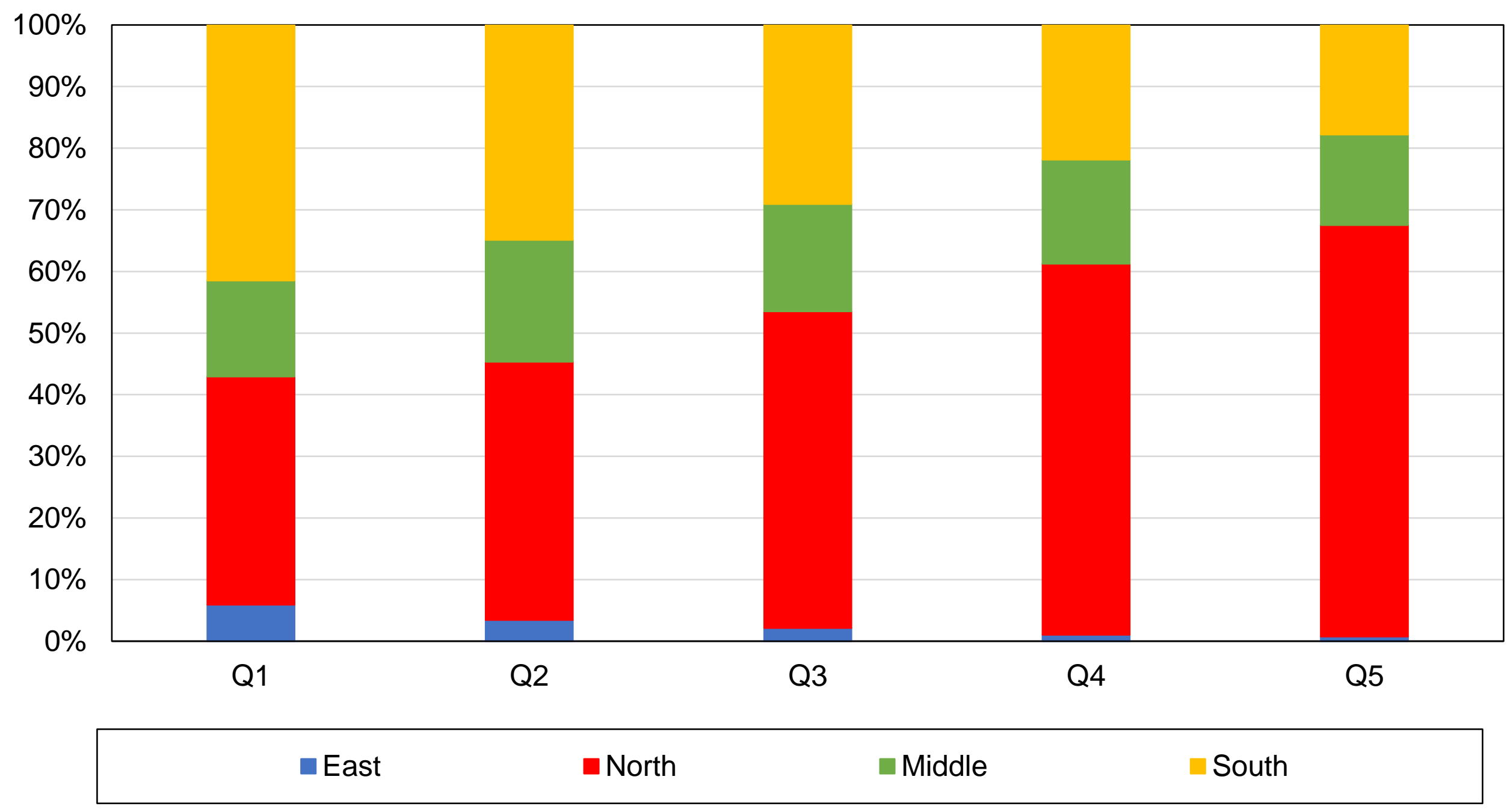

Source: authors' computations using Taiwanese political attitudes surveys.

Note: the figure shows the composition of income quintiles by region in 2016 . 
Figure B21 - Vote for DPP by region

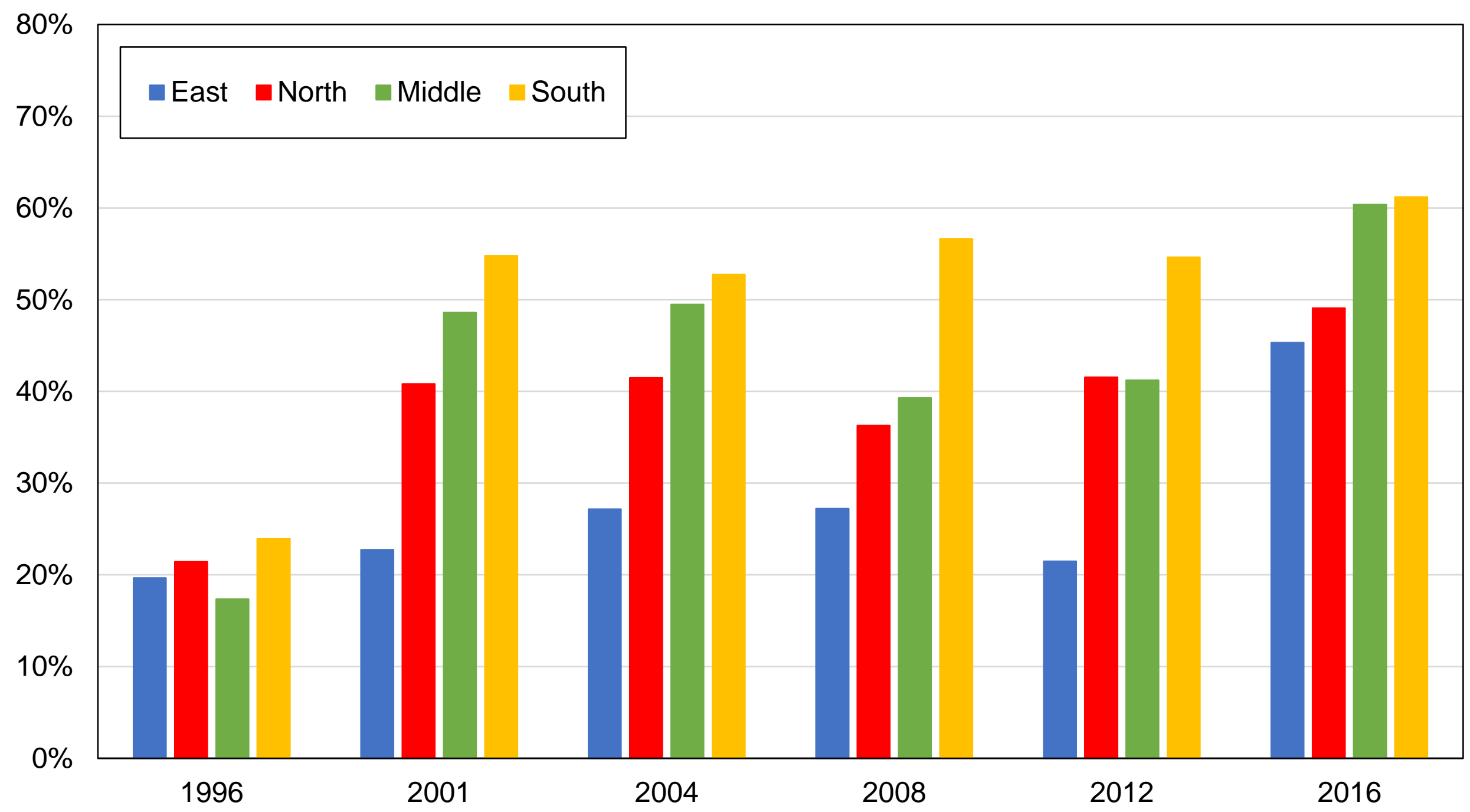

Source: authors' computations using Taiwanese political attitudes surveys.

Note: the figure shows the share of votes received by the DPP by region. 
Figure B22 - Vote for DPP by age group

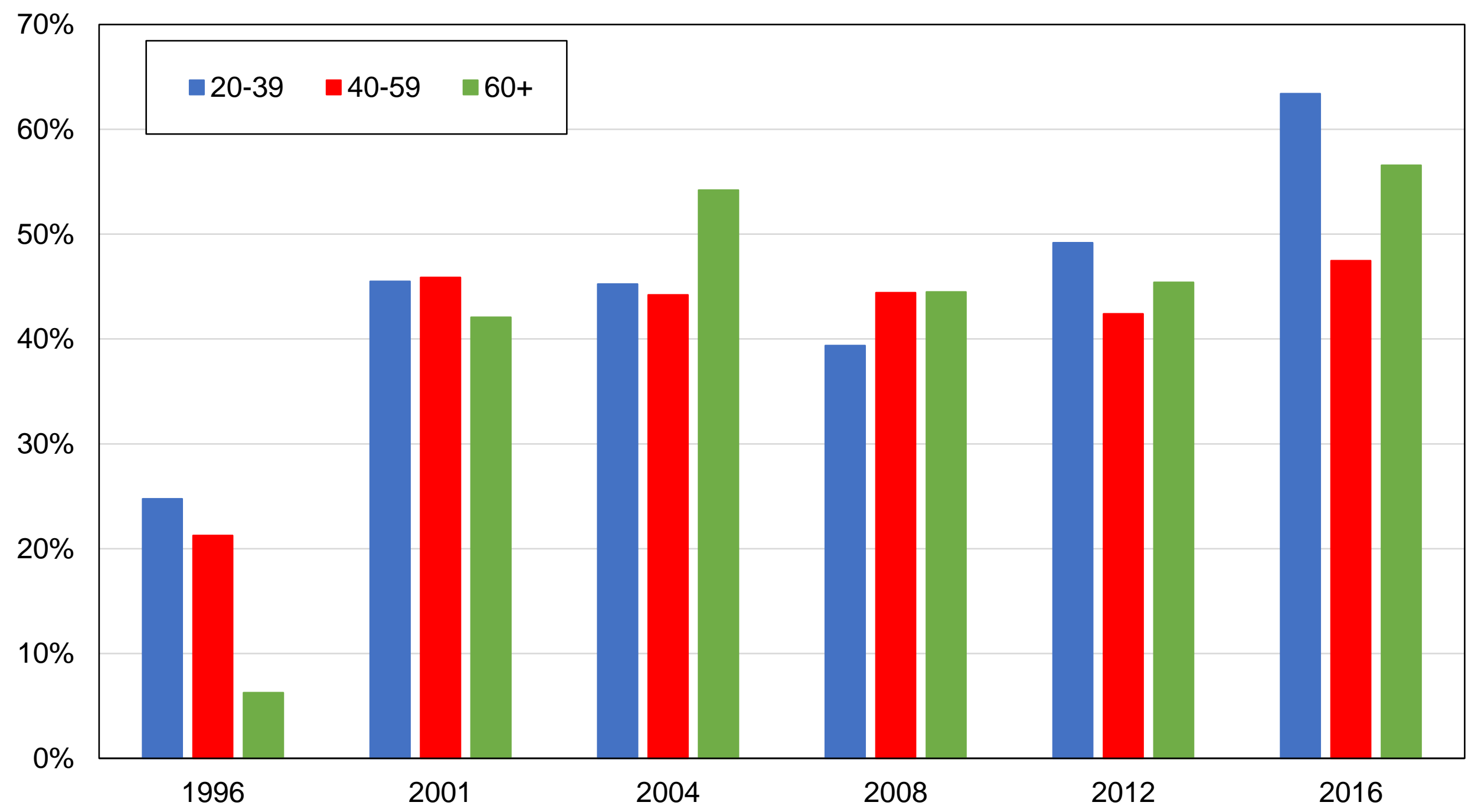

Source: authors' computations using Taiwanese political attitudes surveys.

Note: the figure shows the share of votes received by the DPP by age group. 
Figure B23 - Vote for DPP by education level

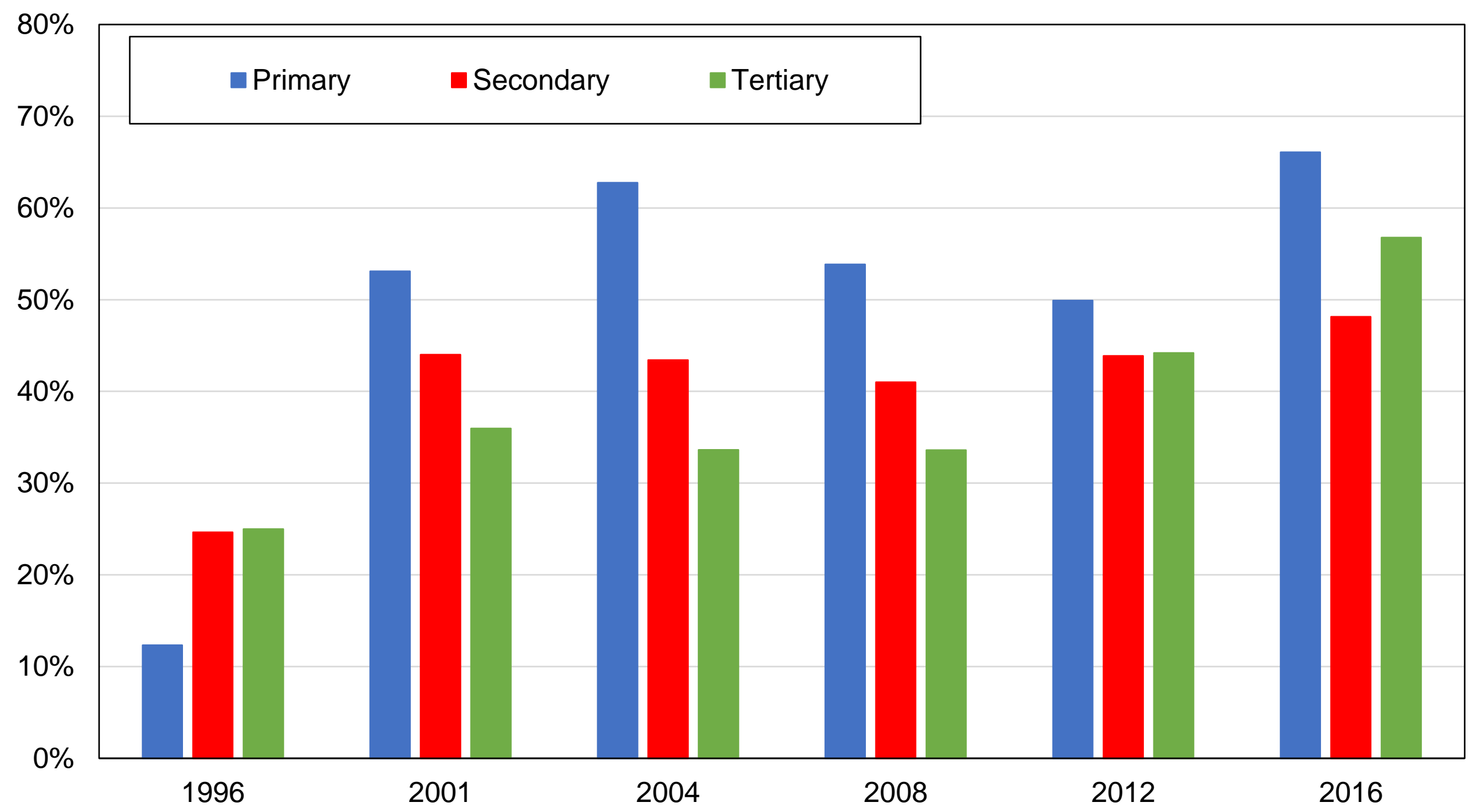

Source: authors' computations using Taiwanese political attitudes surveys.

Note: the figure shows the share of votes received by the DPP by education level. 
Figure B24 - Vote for DPP by education group

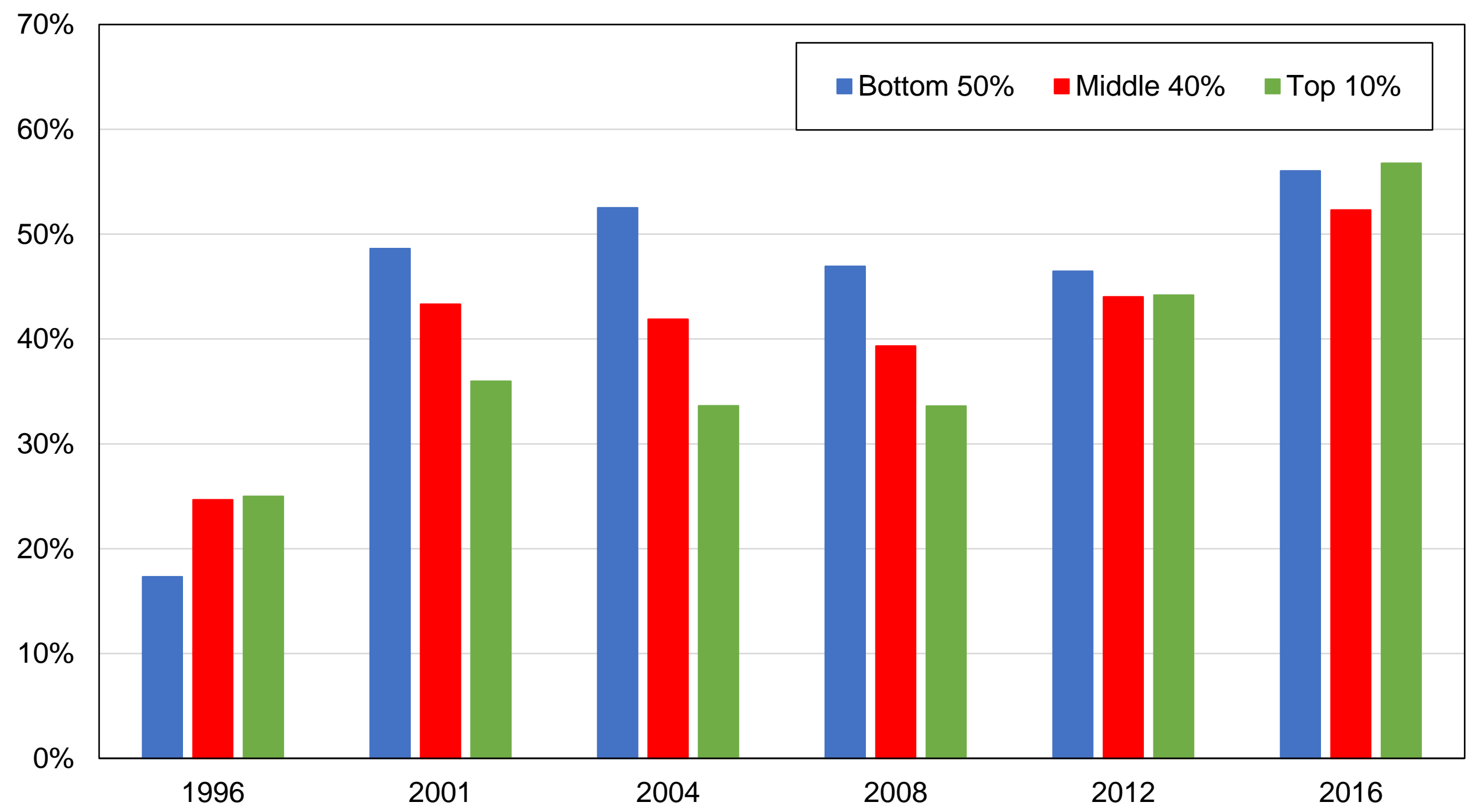

Source: authors' computations using Taiwanese political attitudes surveys.

Note: the figure shows the share of votes received by the DPP by education group. 
Figure B25 - Vote for DPP by income quintile

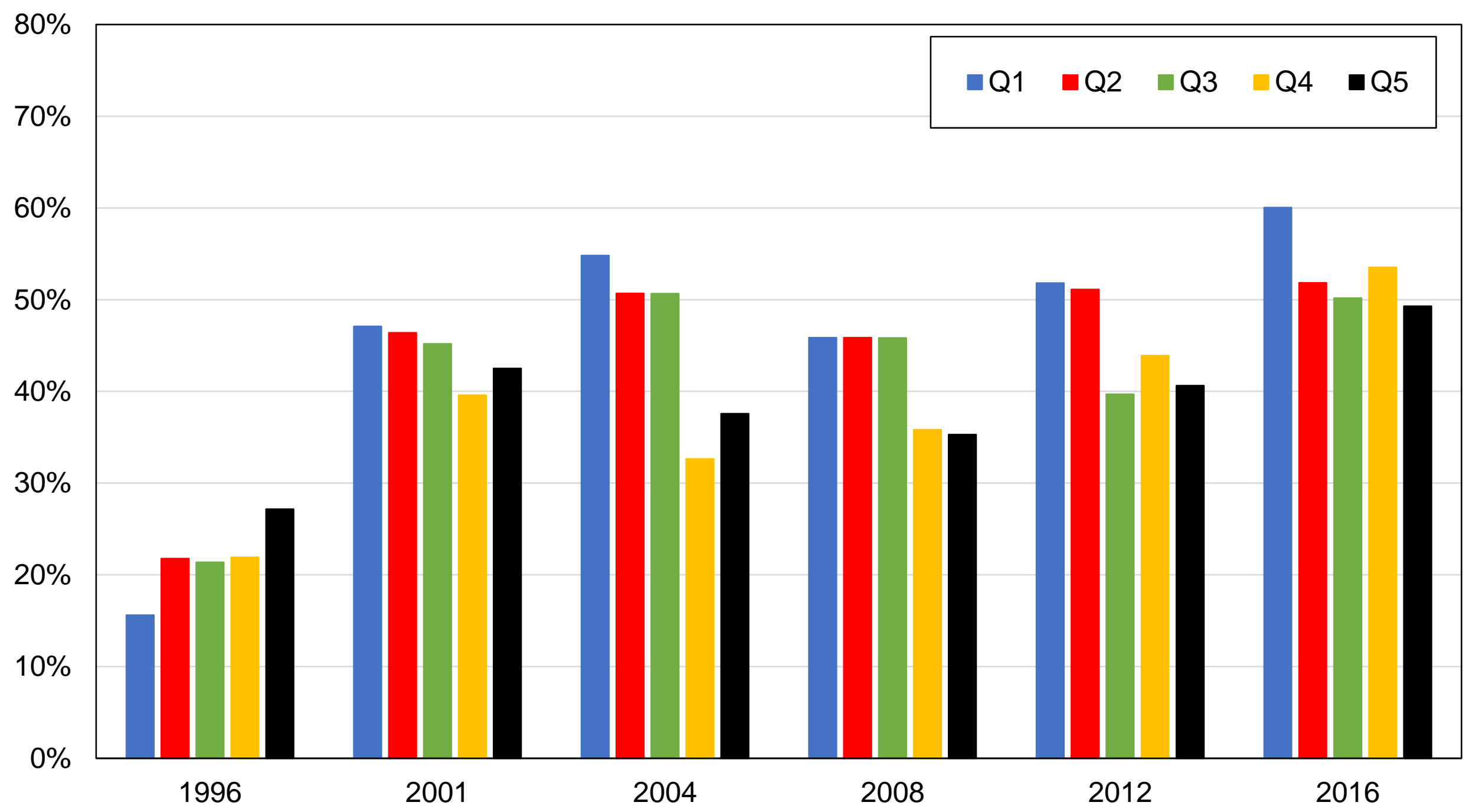

Source: authors' computations using Taiwanese political attitudes surveys.

Note: the figure shows the share of votes received by the DPP by income quintile. 


\section{Figure B26 - Vote for DPP by income quintile}

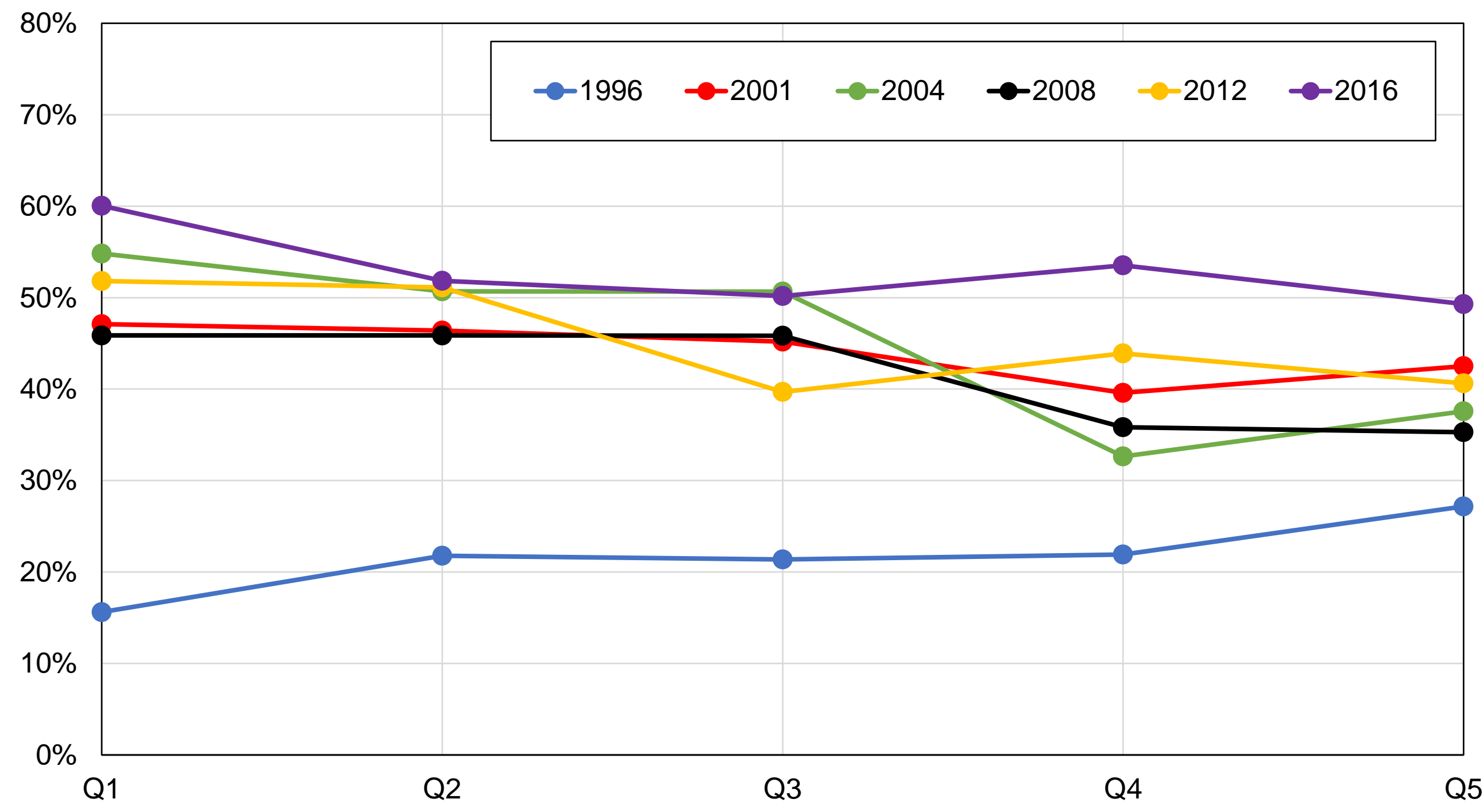

Source: authors' computations using Taiwanese political attitudes surveys.

Note: the figure shows the share of votes received by the DPP by income quintile. 
Figure B27 - Vote for DPP by income group

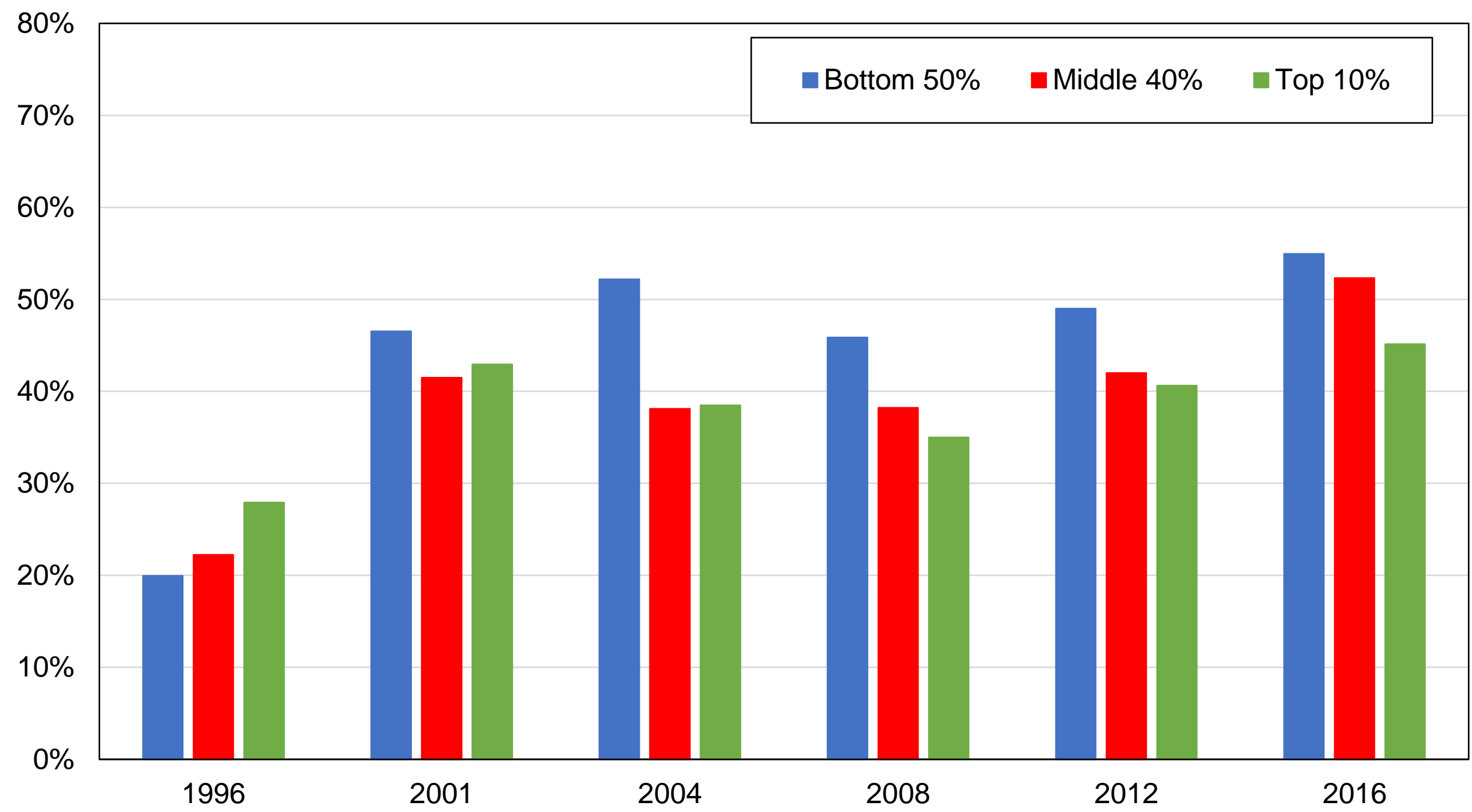

Source: authors' computations using Taiwanese political attitudes surveys.

Note: the figure shows the share of votes received by the DPP by income group. 
Figure B28 - Vote for DPP by union membership

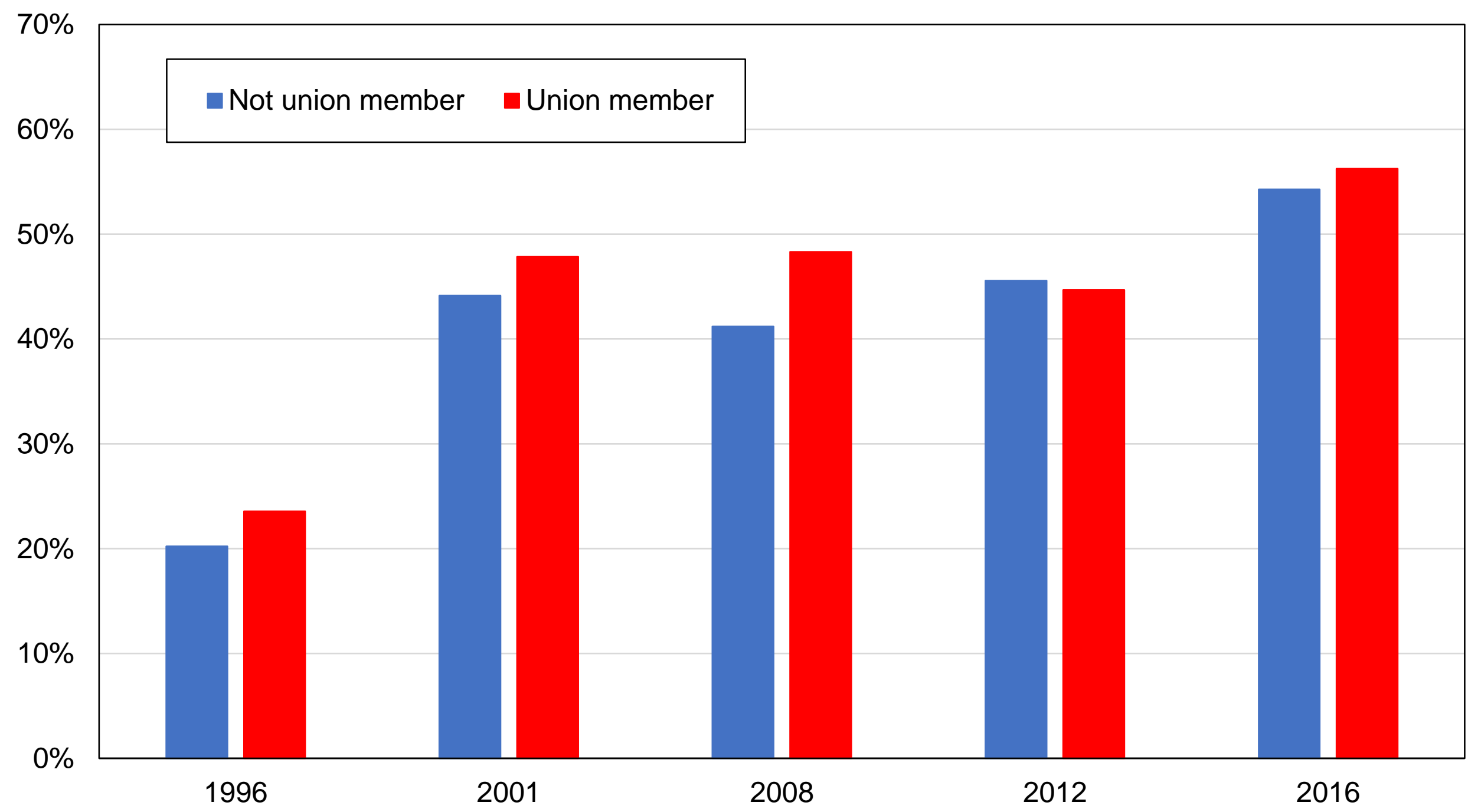

Source: authors' computations using Taiwanese political attitudes surveys.

Note: the figure shows the share of votes received by the DPP by union membership. 
Figure B29 - Vote for DPP by gender

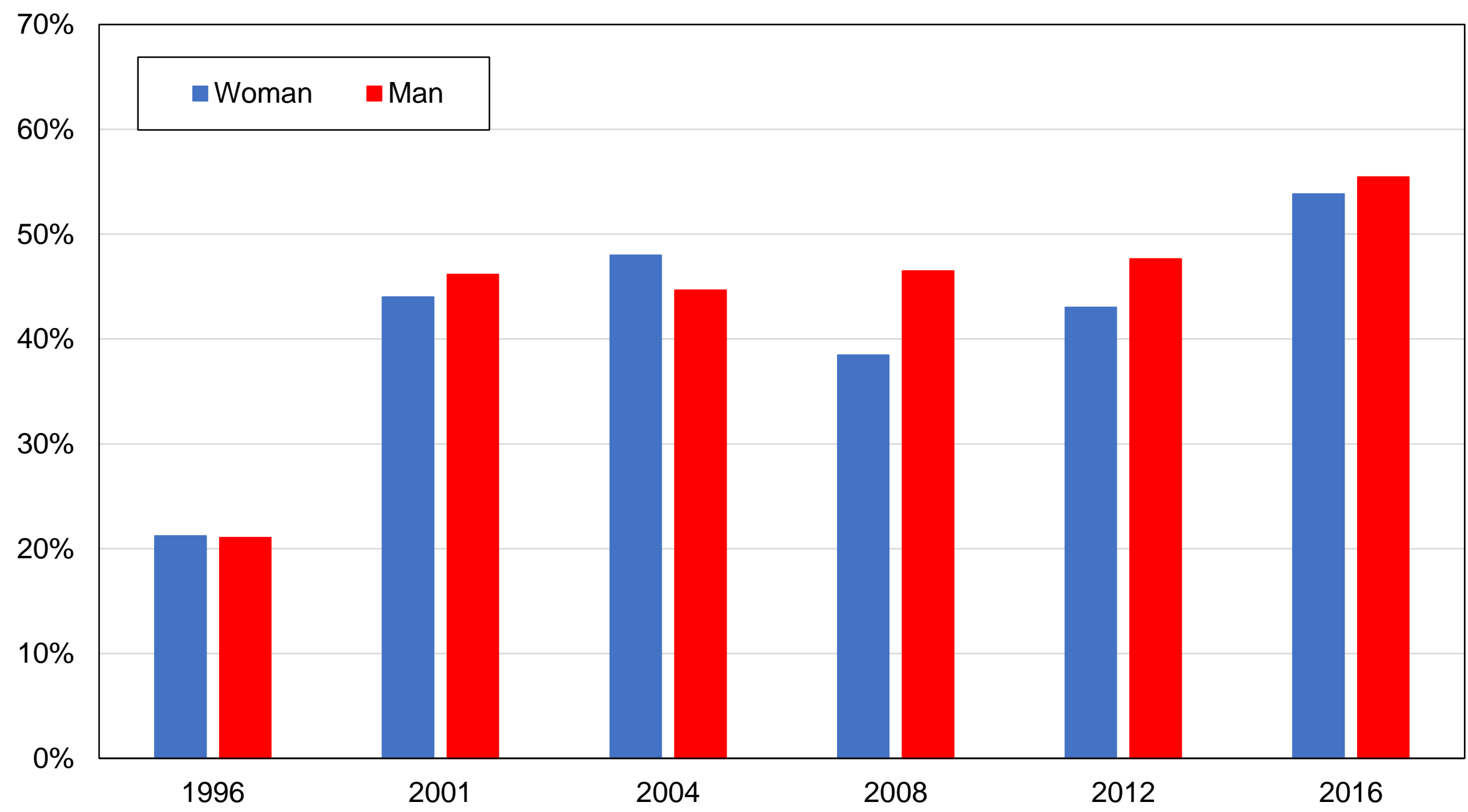

Source: authors' computations using Taiwanese political attitudes surveys. Note: the figure shows the share of votes received by the DPP by gender. 


\section{Figure B30 - Vote for DPP by religion}

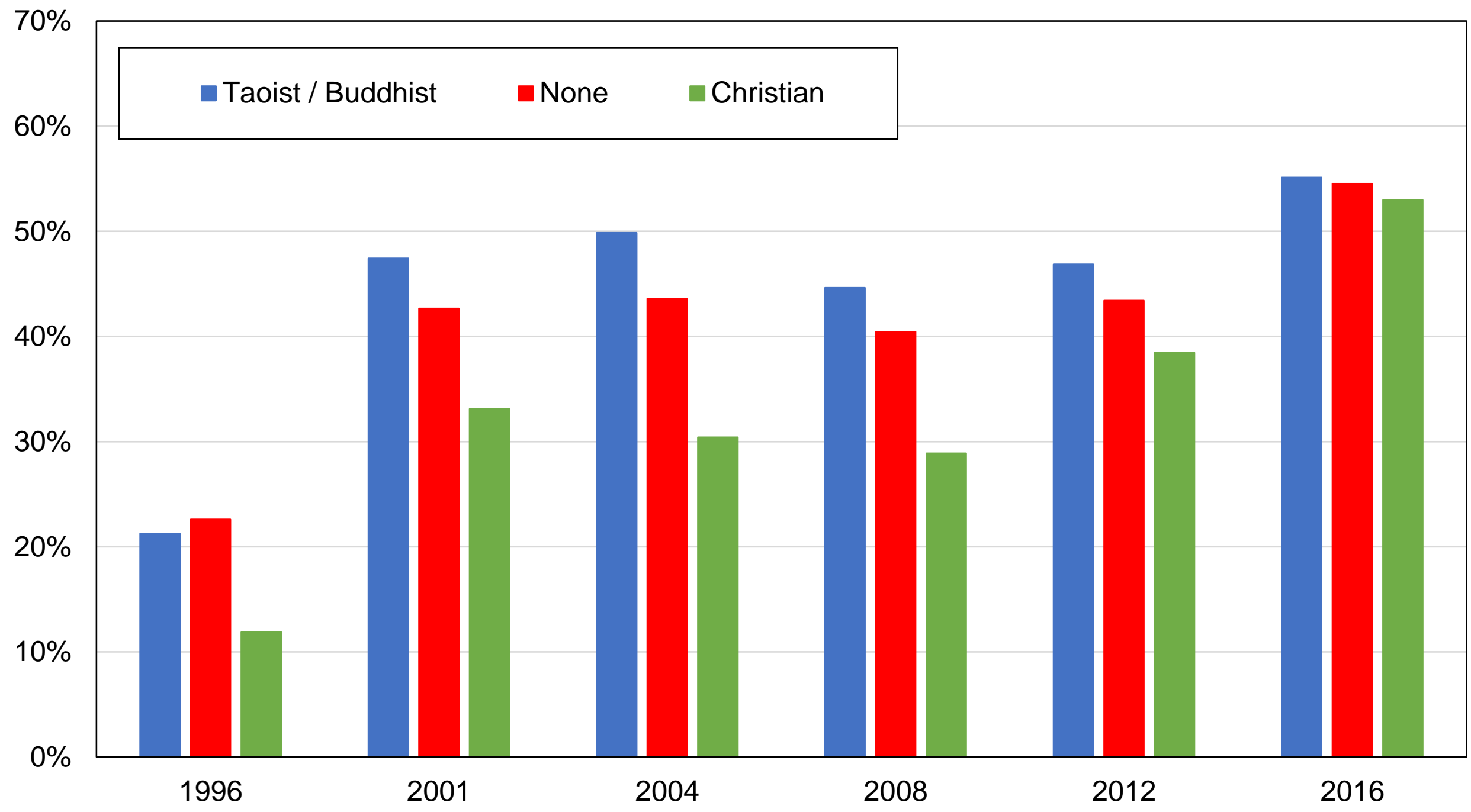

Source: authors' computations using Taiwanese political attitudes surveys.

Note: the figure shows the share of votes received by the DPP by religious affiliation. 
Figure B31 - Vote for DPP by occupation

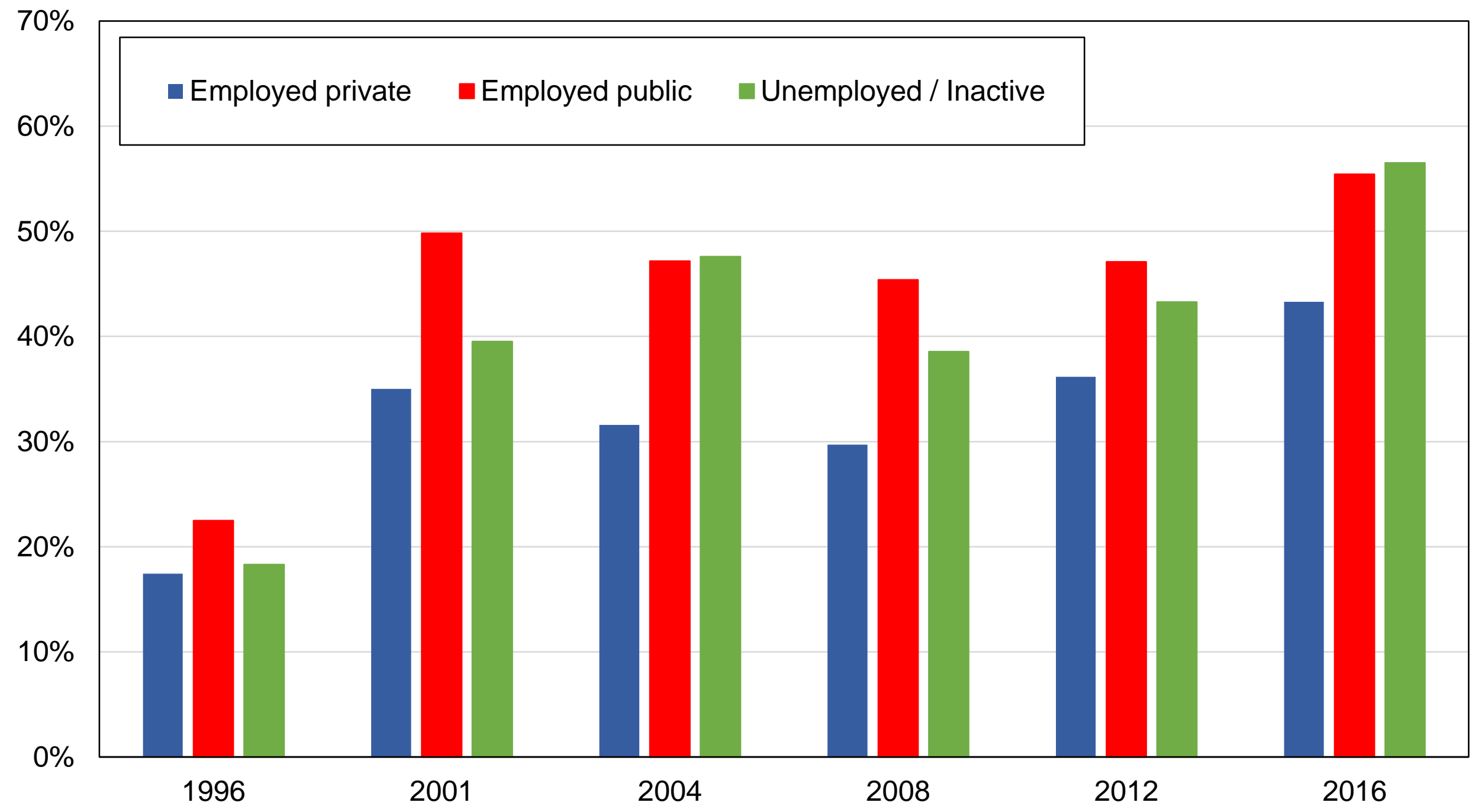

Source: authors' computations using Taiwanese political attitudes surveys.

Note: the figure shows the share of votes received by the DPP by occupation. 
Figure B32 - Vote for DPP by marital status

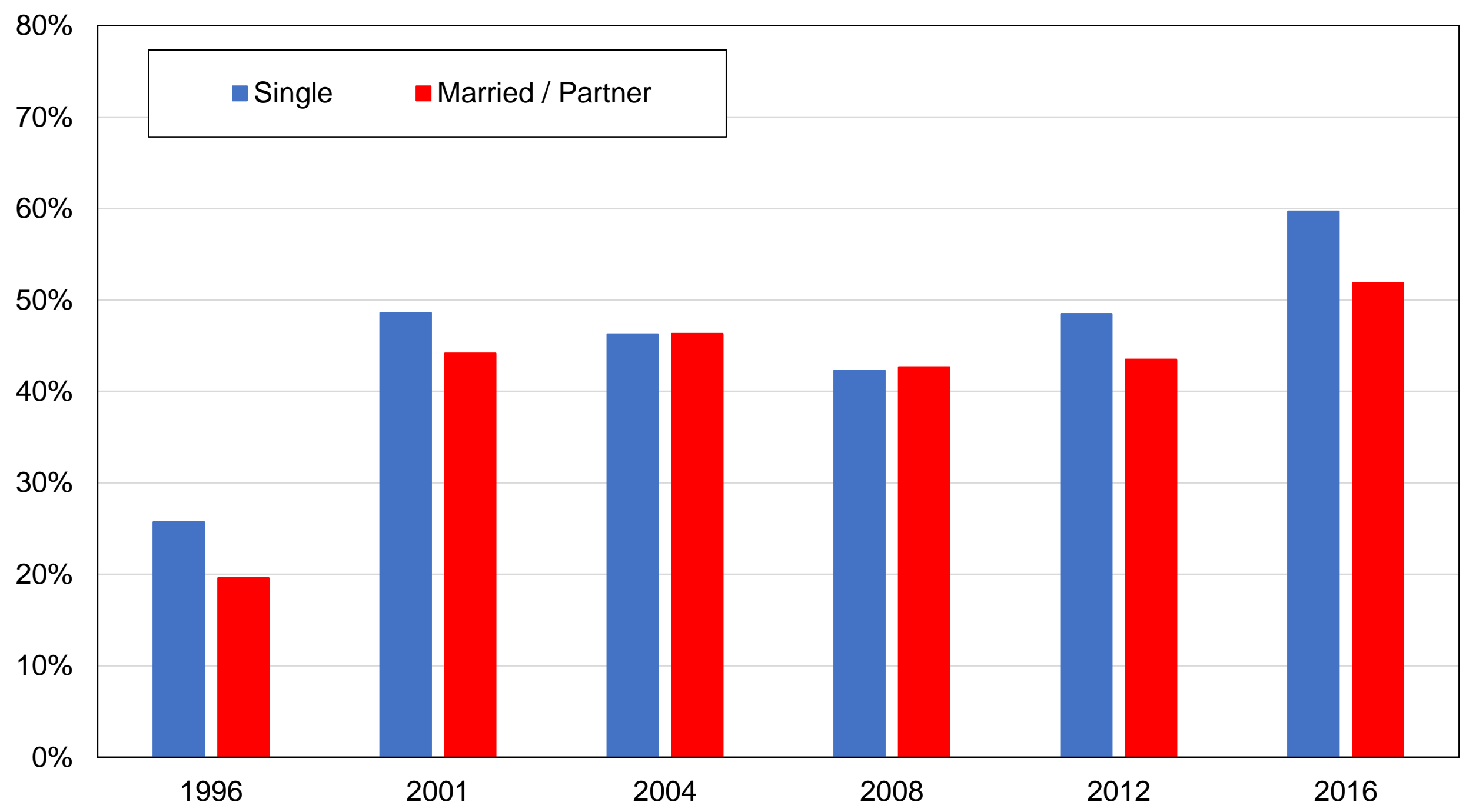

Source: authors' computations using Taiwanese political attitudes surveys.

Note: the figure shows the share of votes received by the DPP by marital status. 


\section{Figure B33 - Vote for DPP among East region residents}

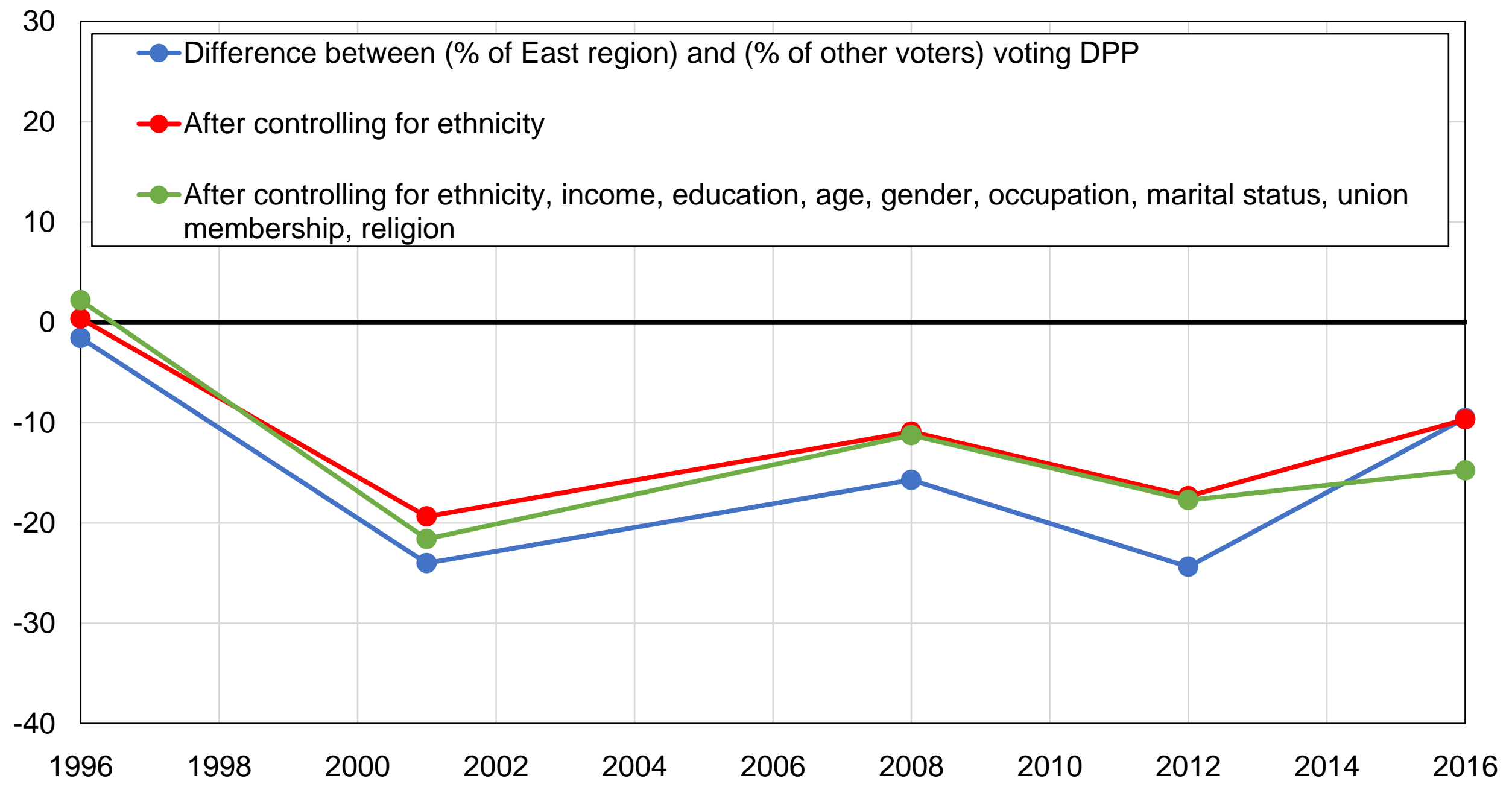

Source: authors' computations using Taiwanese political attitudes surveys.

Note: the figure shows the difference between the share of East region residents and the share of other voters voting for the DPP, before and after controlling for other variables. 


\section{Figure B34 - Vote for DPP among Mainlanders}

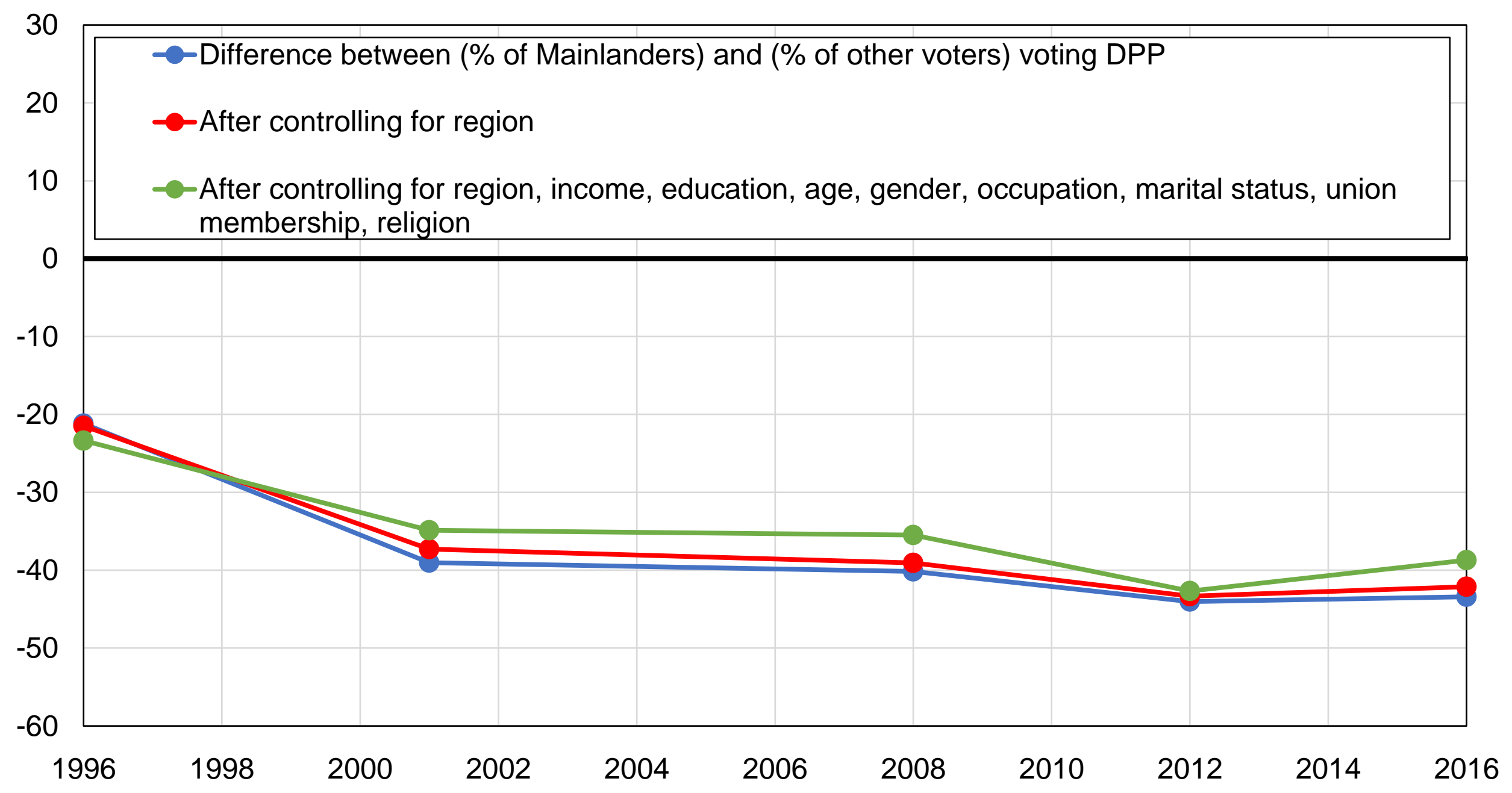

Source: authors' computations using Taiwanese political attitudes surveys.

Note: the figure shows the difference between the share of Mainlanders and the share of other voters voting for the DPP, before and after controlling for other variables. 
Figure B35 - Vote for DPP among highest-educated and top-income voters

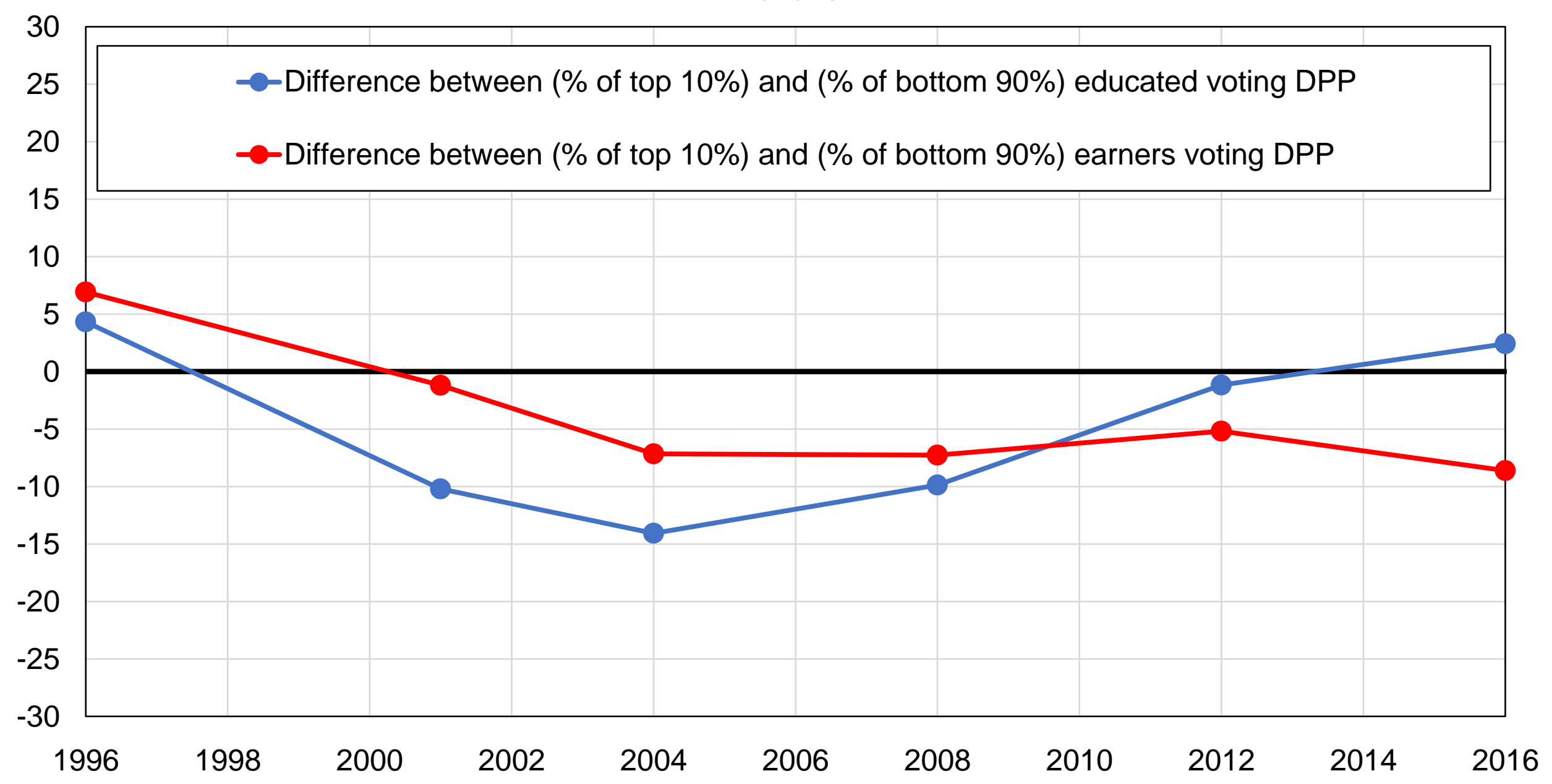

Source: authors' computations using Taiwanese political attitudes surveys.

Note: the figure shows the relative support for the DPP among top-income and highest-educated voters. 
Figure B36 - Vote for DPP among highest-educated and top-income voters, after controls

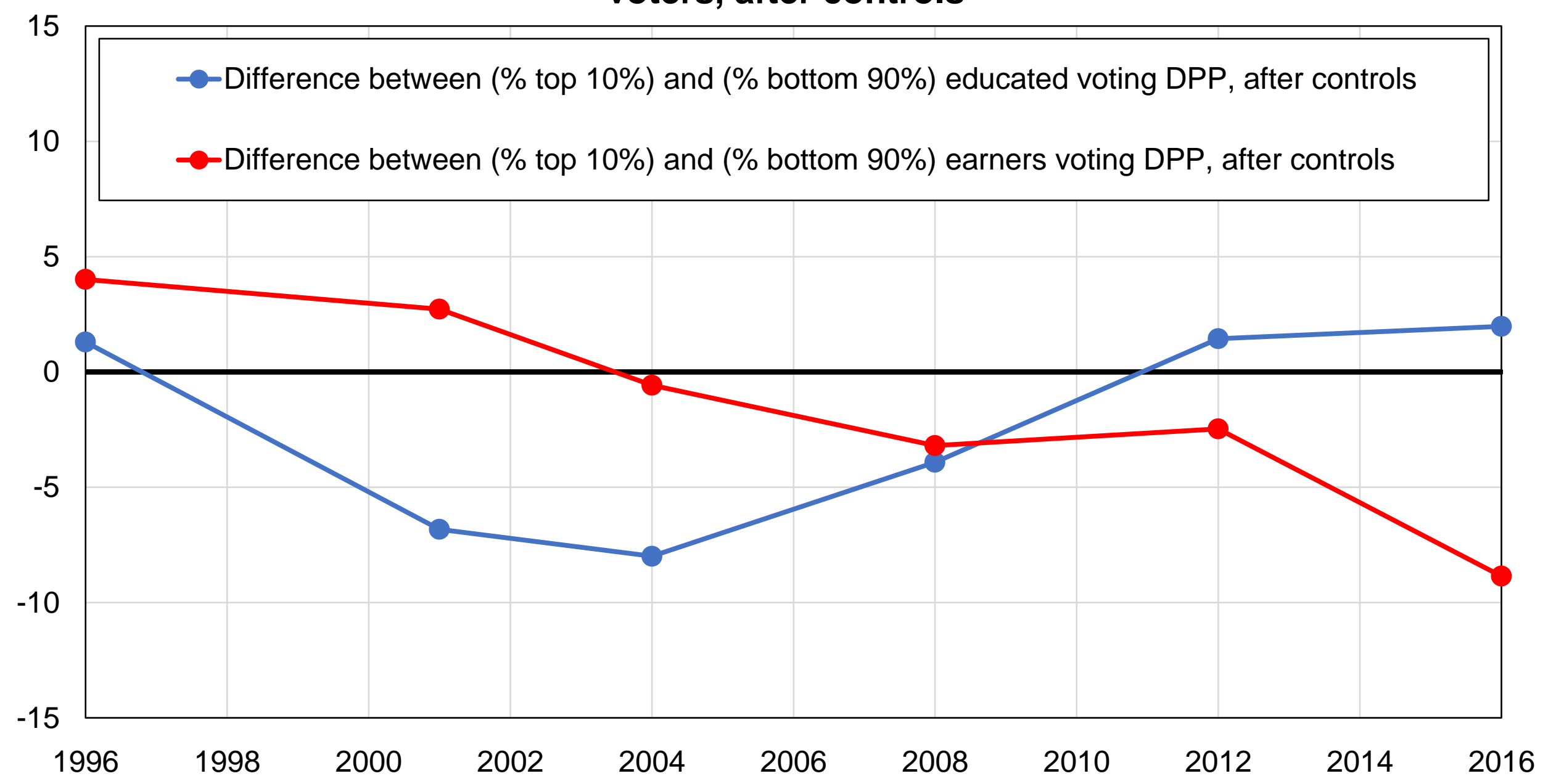

Source: authors' computations using Taiwanese political attitudes surveys.

Note: the figure shows the relative support for the DPP among top-income and highest-educated voters, after controlling for other variables. 


\section{Figure B37 - Vote for DPP among young voters}

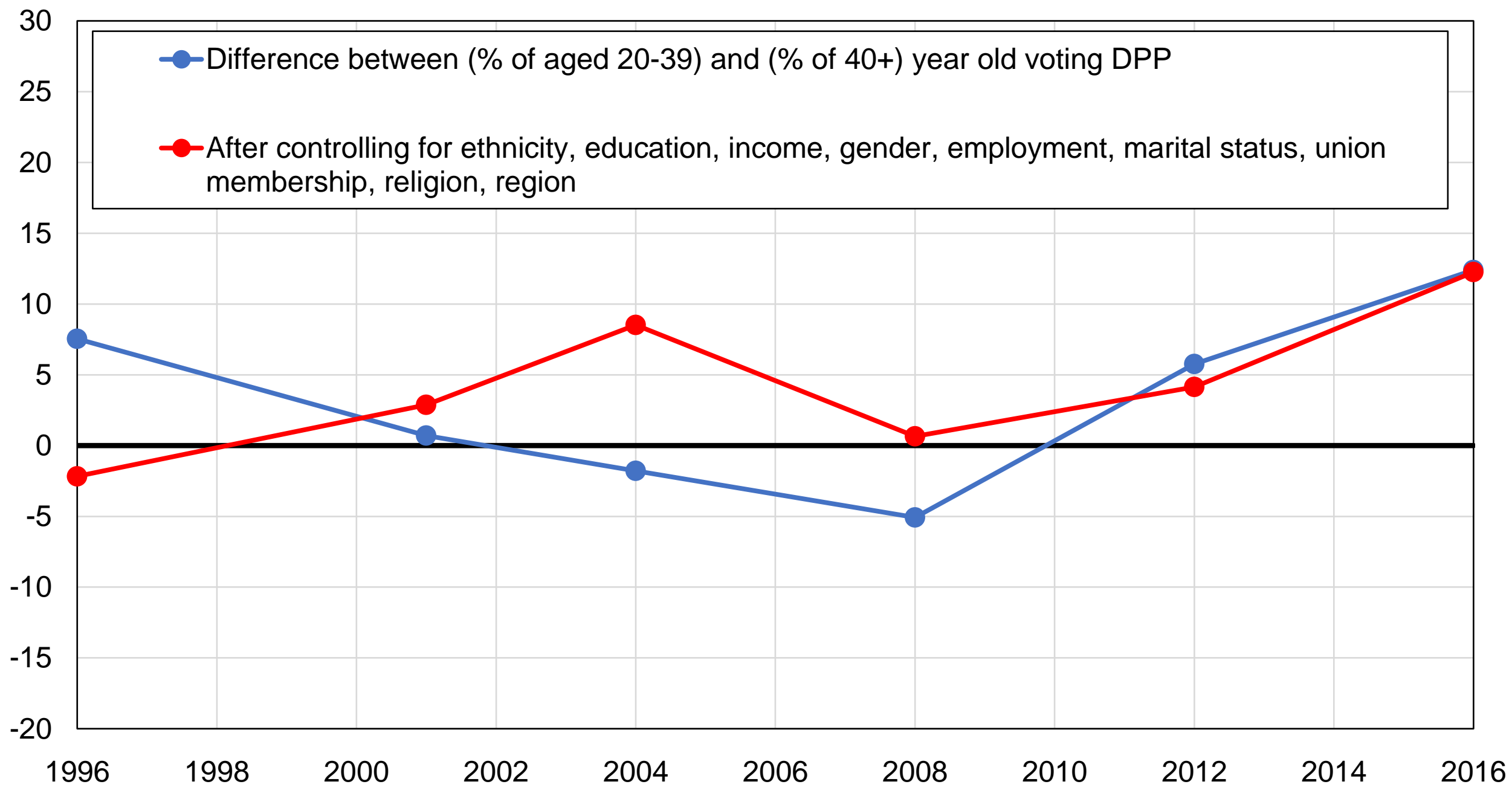

Source: authors' computations using Taiwanese political attitudes surveys.

Note: the figure shows the difference between the share of voters aged 20-39 and the share of voters older than 40 voting for the DPP, before and after controlling for other variables. 


\section{Figure B38 - Vote for DPP among highest-educated voters}

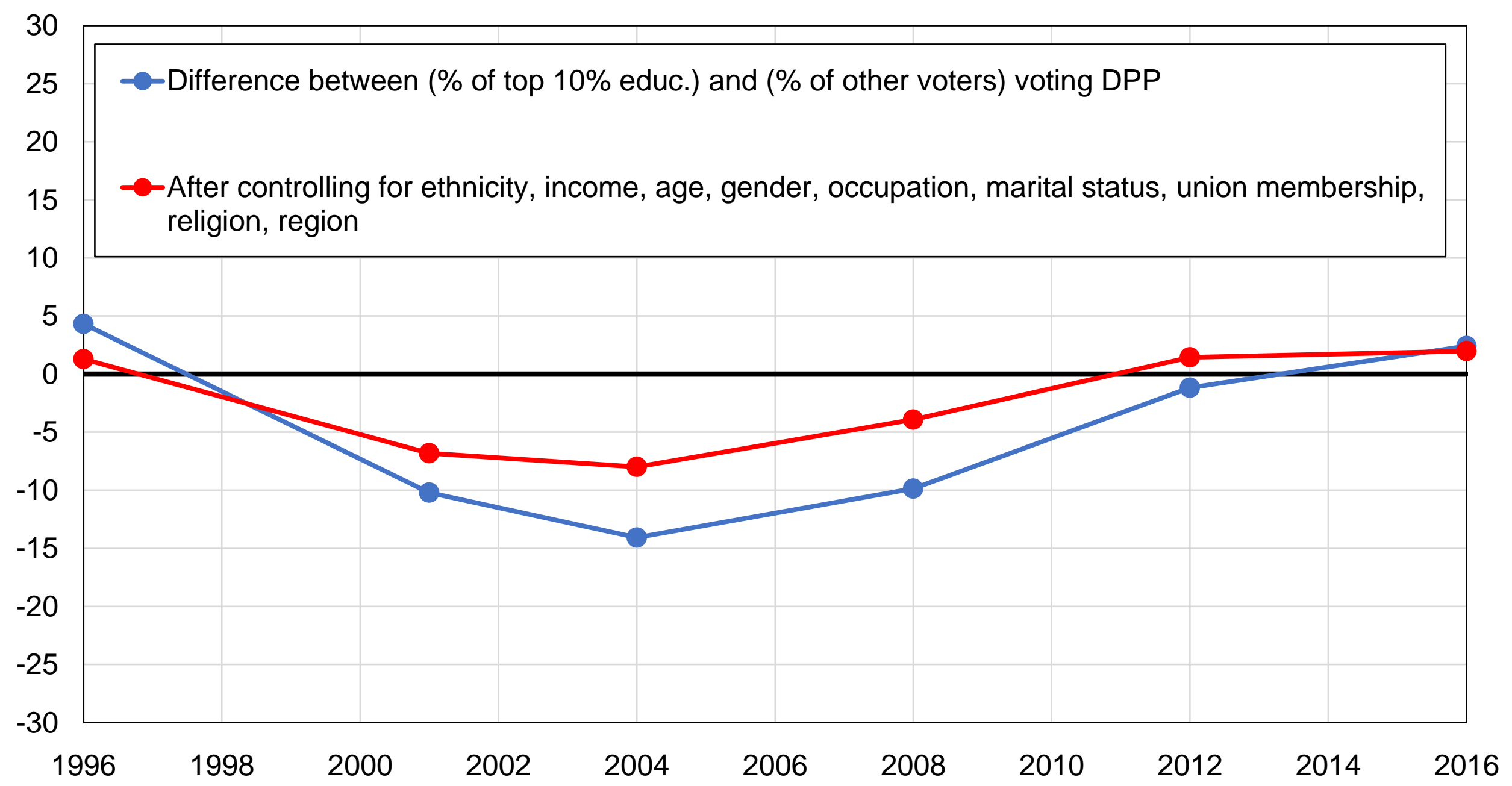

Source: authors' computations using Taiwanese political attitudes surveys.

Note: the figure shows the difference between the share of top $10 \%$ educated voters and the share of other voters voting for the DPP, before and after controlling for other variables. 


\section{Figure B39 - Vote for DPP among lower-educated voters}

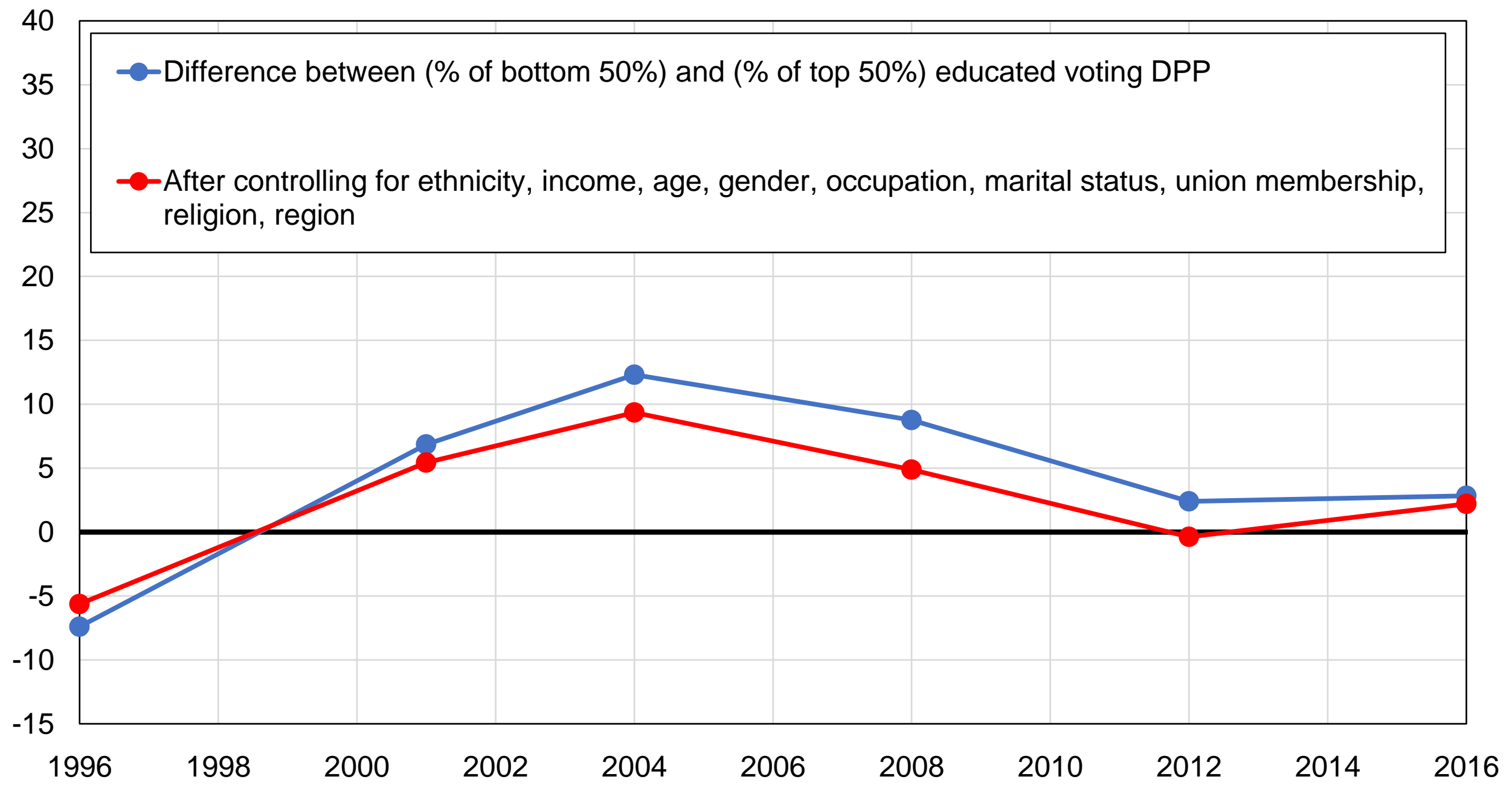

Source: authors' computations using Taiwanese political attitudes surveys.

Note: the figure shows the difference between the share of lower-educated voters and the share of other voters voting for the DPP, before and after controlling for other variables. 


\section{Figure B40 - Vote for DPP among university graduates}

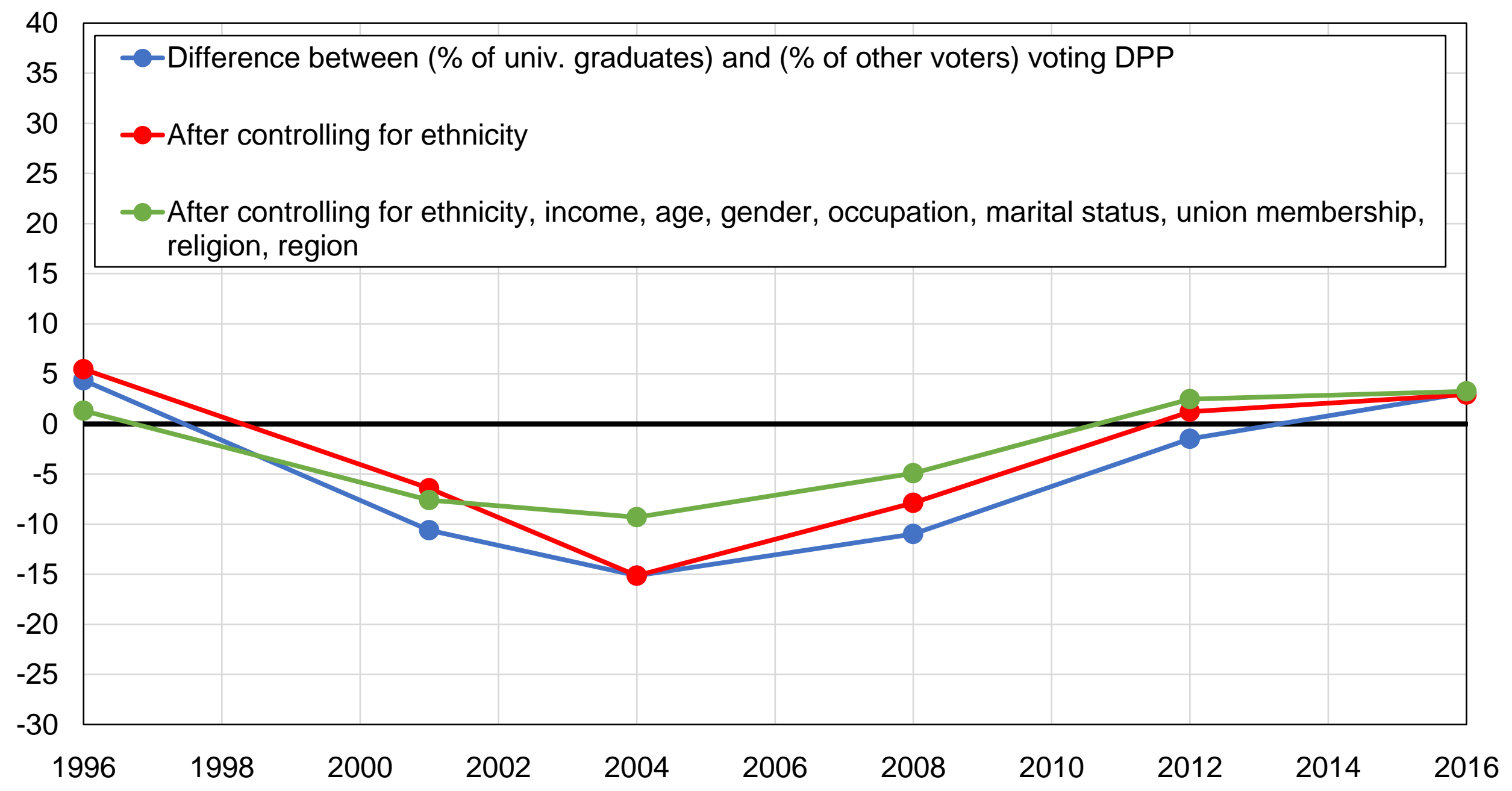

Source: authors' computations using Taiwanese political attitudes surveys.

Note: the figure shows the difference between the share of university graduates and the share of other voters voting for the DPP, before and after controlling for other variables. 


\section{Figure B41 - Vote for DPP among union members}

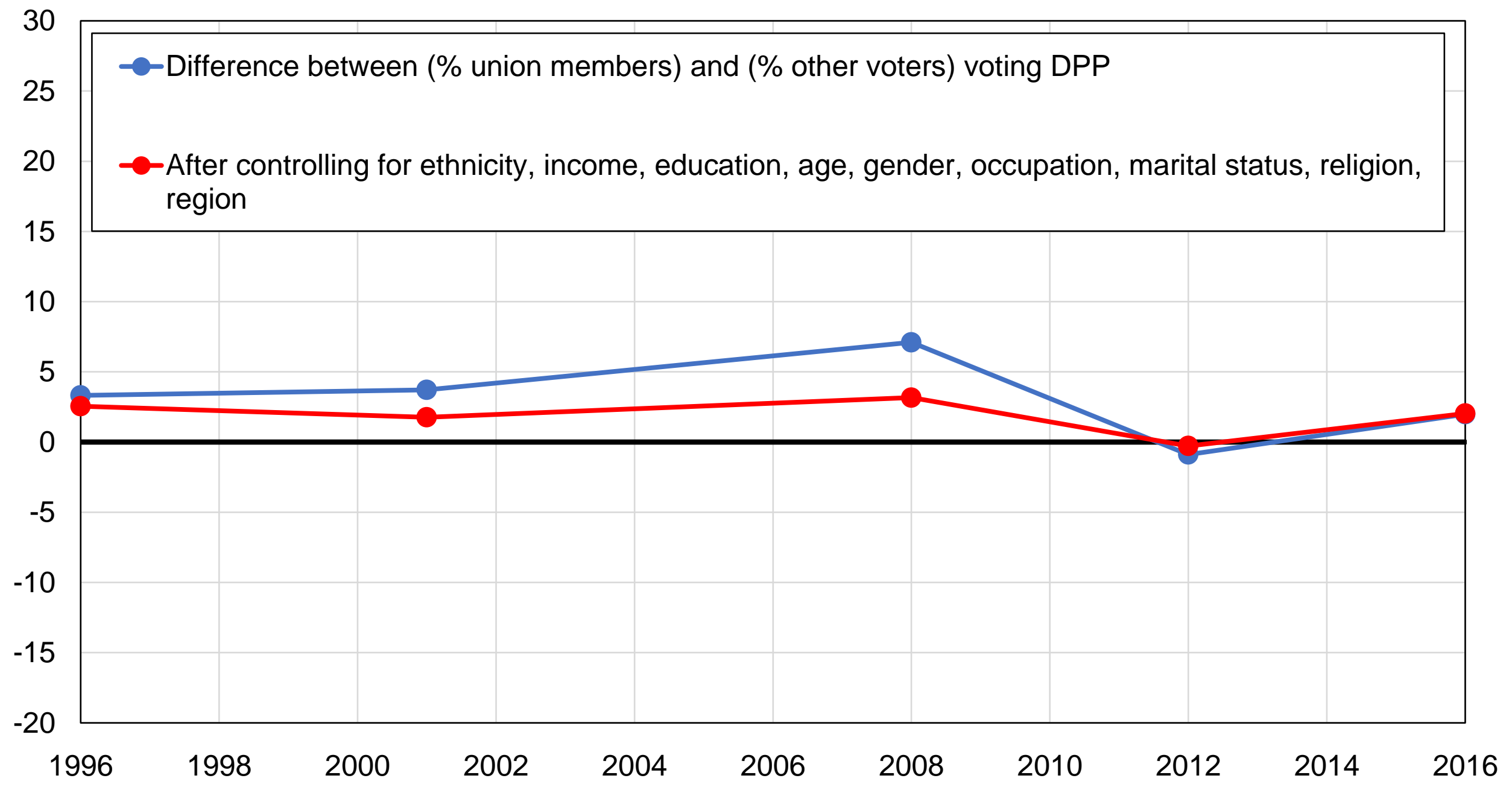

Source: authors' computations using Taiwanese political attitudes surveys.

Note: the figure shows the difference between the share of union members and the share of other voters voting for the DPP, before and after controlling for other variables. 


\section{Figure B42 - Vote for DPP among women}

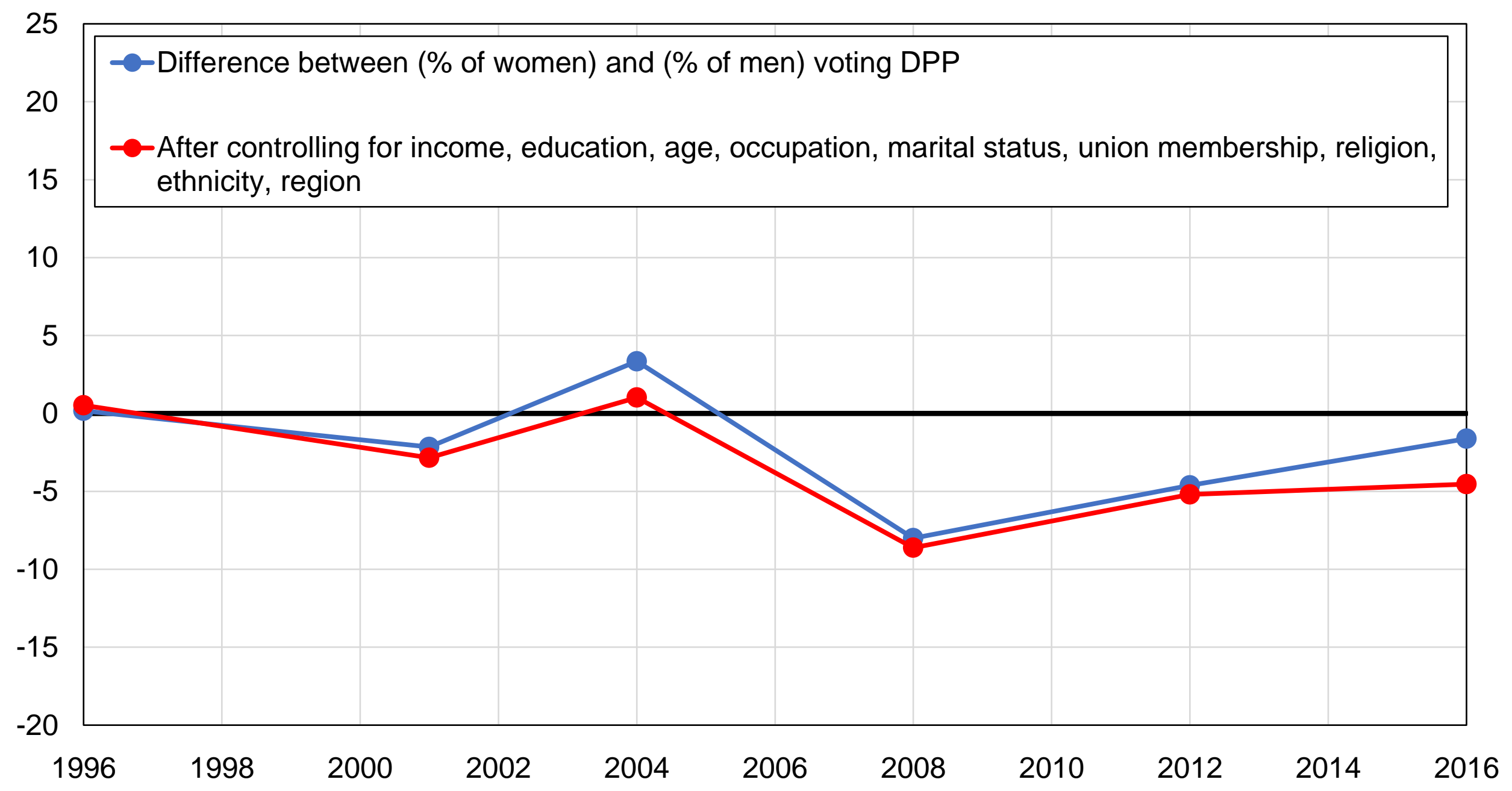

Source: authors' computations using Taiwanese political attitudes surveys.

Note: the figure shows the difference between the share of women and the share of men voting for the DPP, before and after controlling for other variables. 


\section{Figure B43 - Vote for DPP among non-single voters}

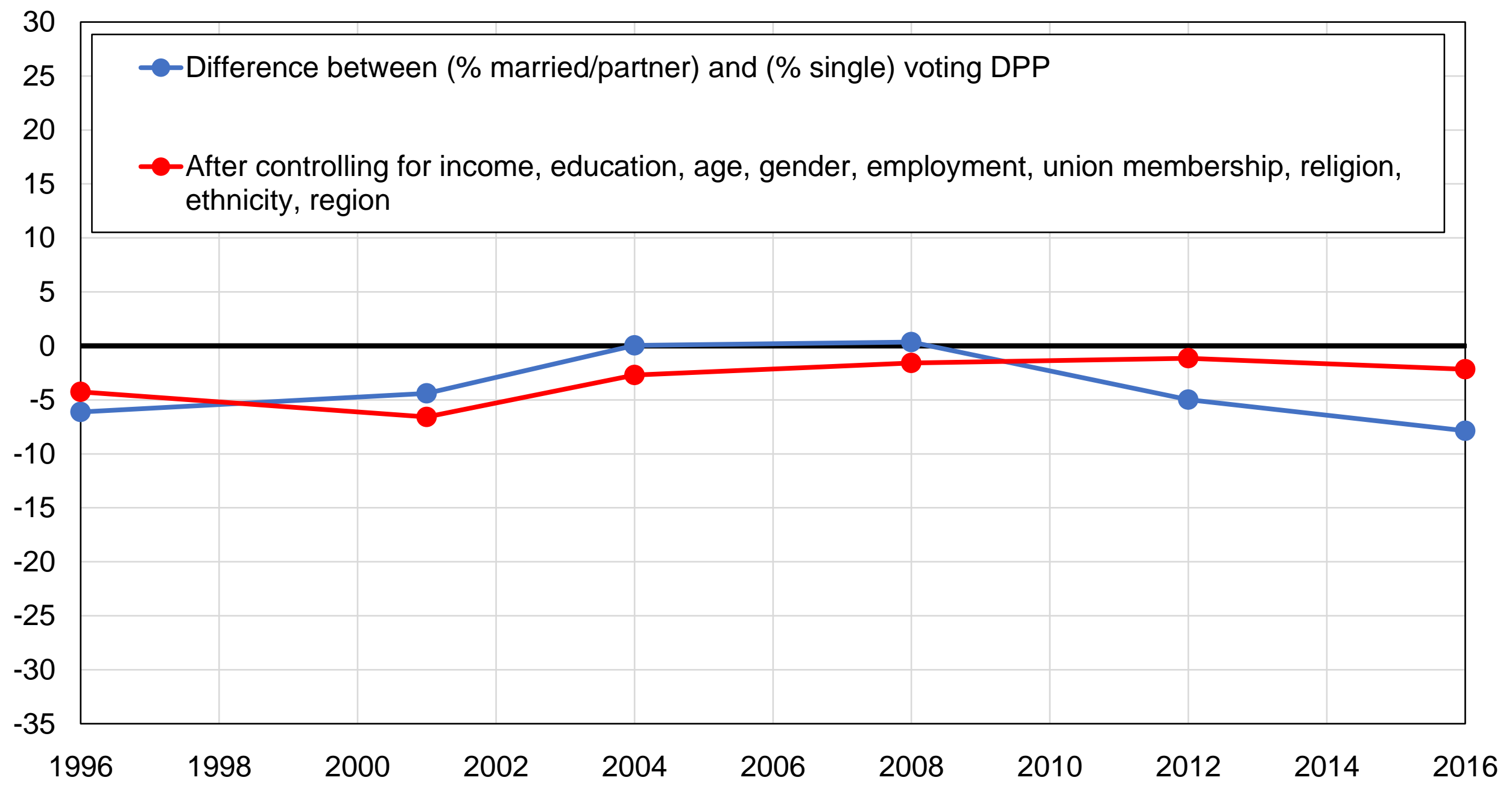

Source: authors' computations using Taiwanese political attitudes surveys.

Note: the figure shows the difference between the share of married voters or voters with partners and the share of other voters voting for the DPP, before and after controlling for other variables. 


\section{Figure B44 - Vote for DPP among Taoists / Buddhists}

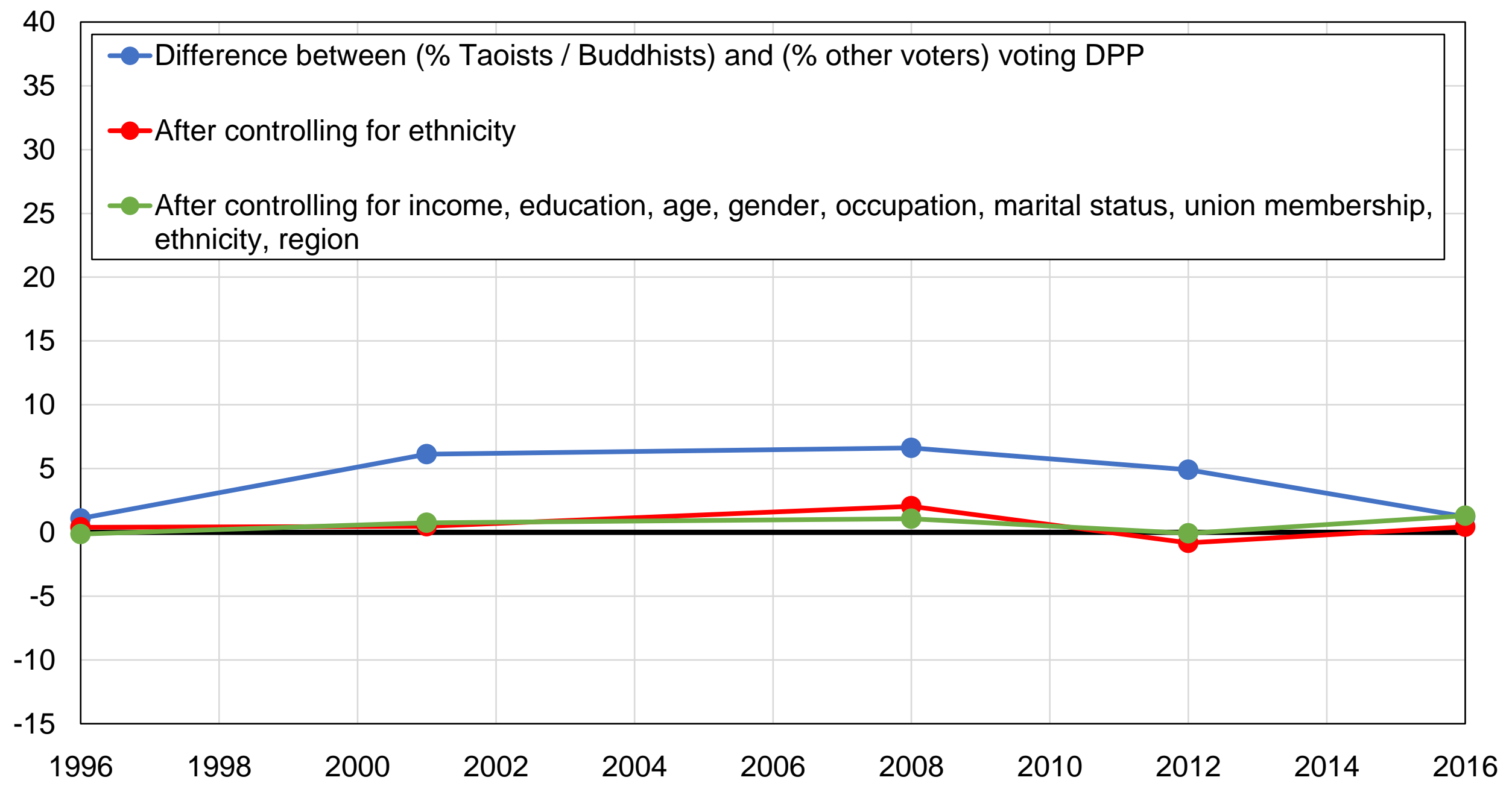

Source: authors' computations using Taiwanese political attitudes surveys.

Note: the figure shows the difference between the share of Buddhists / Taoists and the share of other voters voting for the DPP, before and after controlling for other variables. 


\begin{tabular}{|cccc|}
\hline \multicolumn{5}{|c|}{ Table B1 - Survey data sources } \\
\hline Year & Survey & Source & Sample size \\
\hline 1998 & Comparative Study of Electoral Systems & CSES & 1000 \\
2000 & Comparative Study of Electoral Systems & CSES & 674 \\
2004 & Comparative Study of Electoral Systems & CSES & 582 \\
2012 & Comparative Study of Electoral Systems & CSES & 1044 \\
2016 & Comparative Study of Electoral Systems & CSES & 1020 \\
\hline Source: authors' elaboration. \\
Note: the table shows the surveys used in the paper, the source from which these surveys can be \\
obtained, and the sample size of each survey. CSES: Comparative Study of Electoral Systems. \\
\hline \multicolumn{4}{|l}{} \\
\hline
\end{tabular}




\begin{tabular}{|c|c|c|c|c|c|c|}
\hline \multicolumn{7}{|c|}{ Table B2 - Complete descriptive statistics by year } \\
\hline & 1996 & 2001 & 2004 & 2008 & 2012 & 2016 \\
\hline Education: Primary & $31 \%$ & $27 \%$ & $24 \%$ & $24 \%$ & $22 \%$ & $22 \%$ \\
\hline Education: Secondary & $58 \%$ & $60 \%$ & $60 \%$ & $57 \%$ & $50 \%$ & $49 \%$ \\
\hline Education: Tertiary & $11 \%$ & $13 \%$ & $16 \%$ & $19 \%$ & $28 \%$ & $29 \%$ \\
\hline Age: $20-40$ & $50 \%$ & $45 \%$ & $41 \%$ & $38 \%$ & $35 \%$ & $32 \%$ \\
\hline Age: $40-60$ & $35 \%$ & $37 \%$ & $42 \%$ & $41 \%$ & $42 \%$ & $42 \%$ \\
\hline Age: $60+$ & $14 \%$ & $18 \%$ & $17 \%$ & $21 \%$ & $23 \%$ & $26 \%$ \\
\hline Gender: Man & $51 \%$ & $50 \%$ & $51 \%$ & $51 \%$ & $51 \%$ & $51 \%$ \\
\hline Employment status: Employed & $76 \%$ & $67 \%$ & $66 \%$ & $65 \%$ & $62 \%$ & $66 \%$ \\
\hline Employment status: Unemployed & $1 \%$ & $5 \%$ & $3 \%$ & $4 \%$ & $4 \%$ & $3 \%$ \\
\hline Employment status: Inactive & $24 \%$ & $29 \%$ & $31 \%$ & $31 \%$ & $34 \%$ & $31 \%$ \\
\hline Marital status: Married / With partner & $73 \%$ & $73 \%$ & $73 \%$ & $67 \%$ & $63 \%$ & $63 \%$ \\
\hline Religion: No religion & $3 \%$ & $5 \%$ & $8 \%$ & $7 \%$ & $9 \%$ & $16 \%$ \\
\hline Religion: Christian & $9 \%$ & $35 \%$ & $33 \%$ & $26 \%$ & $24 \%$ & $25 \%$ \\
\hline Religion: Protestant & $88 \%$ & $60 \%$ & $59 \%$ & $67 \%$ & $66 \%$ & $59 \%$ \\
\hline Union membership: Yes & $24 \%$ & $23 \%$ & & $17 \%$ & $19 \%$ & $22 \%$ \\
\hline Region: East & $5 \%$ & $7 \%$ & $3 \%$ & $3 \%$ & $2 \%$ & $3 \%$ \\
\hline Region: Middle & $23 \%$ & $20 \%$ & $30 \%$ & $27 \%$ & $19 \%$ & $17 \%$ \\
\hline Region: North & $43 \%$ & $43 \%$ & $41 \%$ & $42 \%$ & $46 \%$ & $49 \%$ \\
\hline Region: South & $29 \%$ & $30 \%$ & $26 \%$ & $28 \%$ & $33 \%$ & $31 \%$ \\
\hline Ethnicity: Hakka & $11 \%$ & $12 \%$ & & $13 \%$ & $12 \%$ & $14 \%$ \\
\hline Ethnicity: Mainlander & $12 \%$ & $12 \%$ & & $11 \%$ & $11 \%$ & $11 \%$ \\
\hline Ethnicity: Minnan & $76 \%$ & $75 \%$ & & $74 \%$ & $75 \%$ & $72 \%$ \\
\hline Ethnicity: Other & $1 \%$ & $2 \%$ & & $3 \%$ & $2 \%$ & $3 \%$ \\
\hline
\end{tabular}




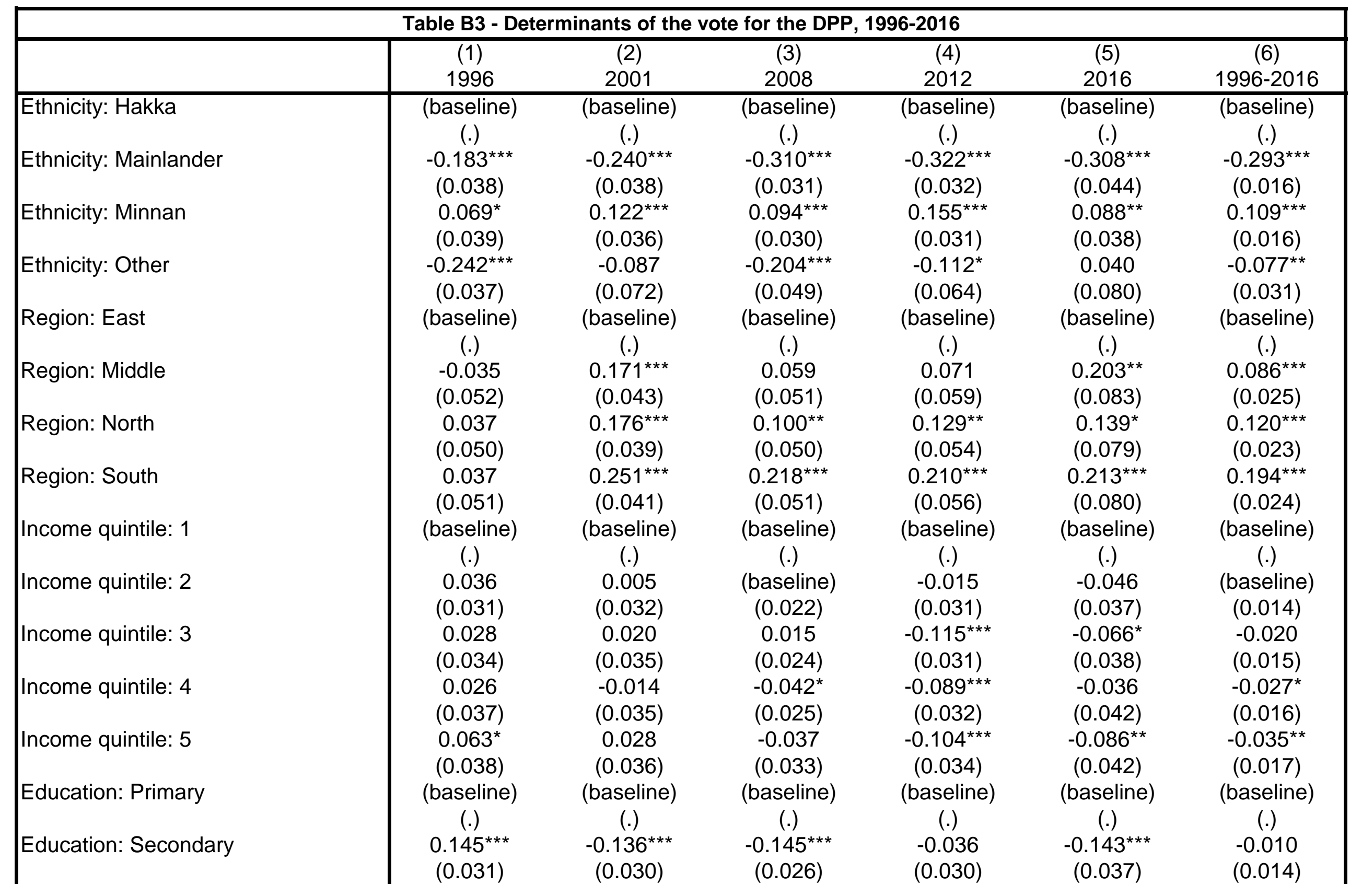




\begin{tabular}{|c|c|c|c|c|c|c|}
\hline Education: Tertiary & $\begin{array}{l}0.091^{*} \\
(0.046)\end{array}$ & $\begin{array}{c}-0.216^{* * *} \\
(0.041)\end{array}$ & $\begin{array}{c}-0.158^{* * *} \\
(0.035)\end{array}$ & $\begin{array}{l}-0.026 \\
(0.036)\end{array}$ & $\begin{array}{l}-0.068 \\
(0.045)\end{array}$ & $\begin{array}{c}0.023 \\
(0.018)\end{array}$ \\
\hline Age: 20-39 & $\begin{array}{c}\text { (baseline) } \\
(.)\end{array}$ & $\begin{array}{c}\text { (baseline) } \\
(.)\end{array}$ & $\begin{array}{c}\text { (baseline) } \\
(.)\end{array}$ & $\begin{array}{c}\text { (baseline) } \\
(.)\end{array}$ & $\begin{array}{c}\text { (baseline) } \\
(.)\end{array}$ & $\begin{array}{c}\text { (baseline) } \\
(.)\end{array}$ \\
\hline $40-59$ & $\begin{array}{c}0.011 \\
(0.030)\end{array}$ & $\begin{array}{l}-0.027 \\
(0.026)\end{array}$ & $\begin{array}{c}0.004 \\
(0.023)\end{array}$ & $\begin{array}{l}-0.033 \\
(0.024)\end{array}$ & $\begin{array}{c}-0.117^{\star \star \star} \\
(0.035)\end{array}$ & $\begin{array}{c}0.009 \\
(0.012)\end{array}$ \\
\hline Age: $60+$ & $\begin{array}{l}-0.052 \\
(0.039)\end{array}$ & $\begin{array}{l}-0.051 \\
(0.040)\end{array}$ & $\begin{array}{l}-0.061^{*} \\
(0.033)\end{array}$ & $\begin{array}{l}-0.057 \\
(0.036)\end{array}$ & $\begin{array}{l}-0.067 \\
(0.046)\end{array}$ & $\begin{array}{l}0.040^{* *} \\
(0.018)\end{array}$ \\
\hline Gender: Man & $\begin{array}{l}\text { ssive Party amo } \\
\text { ssive Party amo }\end{array}$ & $\begin{array}{c}0.028 \\
(0.022)\end{array}$ & $\begin{array}{c}0.078^{\star \star *} \\
(0.018)\end{array}$ & $\begin{array}{c}0.030 \\
(0.019)\end{array}$ & $\begin{array}{c}0.018 \\
(0.025)\end{array}$ & $\begin{array}{c}0.016 \\
(0.010)\end{array}$ \\
\hline Religion: Christian & $\begin{array}{c}\text { (baseline) } \\
(.)\end{array}$ & $\begin{array}{c}\text { (baseline) } \\
(.)\end{array}$ & $\begin{array}{c}\text { (baseline) } \\
(.)\end{array}$ & $\begin{array}{c}\text { (baseline) } \\
(.)\end{array}$ & $\begin{array}{c}\text { (baseline) } \\
(.)\end{array}$ & $\begin{array}{c}\text { (baseline) } \\
(.)\end{array}$ \\
\hline Religion: None & $\begin{array}{c}0.086 \\
(0.065)\end{array}$ & $\begin{array}{l}-0.058 \\
(0.045)\end{array}$ & $\begin{array}{l}-0.003 \\
(0.038)\end{array}$ & $\begin{array}{c}0.014 \\
(0.033)\end{array}$ & $\begin{array}{l}-0.000 \\
(0.041)\end{array}$ & $\begin{array}{l}-0.010 \\
(0.019)\end{array}$ \\
\hline Religion: Taoist & $\begin{array}{c}0.053 \\
(0.055)\end{array}$ & $\begin{array}{l}-0.057 \\
(0.044)\end{array}$ & $\begin{array}{c}0.020 \\
(0.037)\end{array}$ & $\begin{array}{c}0.002 \\
(0.030)\end{array}$ & $\begin{array}{c}0.011 \\
(0.035)\end{array}$ & $\begin{array}{c}-0.045^{\star *} \\
(0.018)\end{array}$ \\
\hline Employment status: Inactive & $\begin{array}{c}0.036 \\
(0.029)\end{array}$ & $\begin{array}{l}-0.055^{\star *} \\
(0.028)\end{array}$ & $\begin{array}{l}-0.008 \\
(0.022)\end{array}$ & $\begin{array}{c}-0.083^{* * *} \\
(0.023)\end{array}$ & $\begin{array}{l}-0.037 \\
(0.031)\end{array}$ & $\begin{array}{c}-0.030^{* *} \\
(0.012)\end{array}$ \\
\hline Marital status: Married / Partner & $\begin{array}{l}-0.039 \\
(0.028)\end{array}$ & $\begin{array}{l}-0.078^{\star * *} \\
(0.029)\end{array}$ & $\begin{array}{l}-0.002 \\
(0.021)\end{array}$ & $\begin{array}{l}-0.031 \\
(0.021)\end{array}$ & $\begin{array}{l}-0.032 \\
(0.029)\end{array}$ & $\begin{array}{c}-0.063^{* \star *} \\
(0.011)\end{array}$ \\
\hline Union membership: Yes & $\begin{array}{c}0.029 \\
(0.027)\end{array}$ & $\begin{array}{c}0.003 \\
(0.026)\end{array}$ & $\begin{array}{c}0.020 \\
(0.024)\end{array}$ & $\begin{array}{l}-0.024 \\
(0.023)\end{array}$ & $\begin{array}{c}0.028 \\
(0.031)\end{array}$ & $\begin{array}{c}0.015 \\
(0.012)\end{array}$ \\
\hline Constant & $\begin{array}{c}0.017 \\
(0.086)\end{array}$ & $\begin{array}{l}0.449^{* * *} \\
(0.074)\end{array}$ & $\begin{array}{l}0.368^{* * *} \\
(0.073)\end{array}$ & $\begin{array}{l}0.389^{* * *} \\
(0.079)\end{array}$ & $\begin{array}{c}0.555^{\star * *} \\
(0.097)\end{array}$ & $\begin{array}{c}0.322^{* * *} \\
(0.035)\end{array}$ \\
\hline $\begin{array}{l}\text { R-squared } \\
{ }^{*} p<0.10,{ }^{* *} p<0.05,{ }^{* * *} p<0.01\end{array}$ & 0.08 & 0.12 & 0.14 & 0.14 & 0.12 & 0.09 \\
\hline \multicolumn{7}{|c|}{$\begin{array}{l}\text { Source: authors' computations using Taiwanese political attitudes surveys. } \\
\text { Note: the table shows the results of a multivariate regression assessing the determinants of support for the DPP by year, and over the } \\
\text { entire period studied. } 2004 \text { is excluded since the ethnicity variable was not available. }\end{array}$} \\
\hline
\end{tabular}


Figure C1 - Election results in Hong Kong, 1991-2016

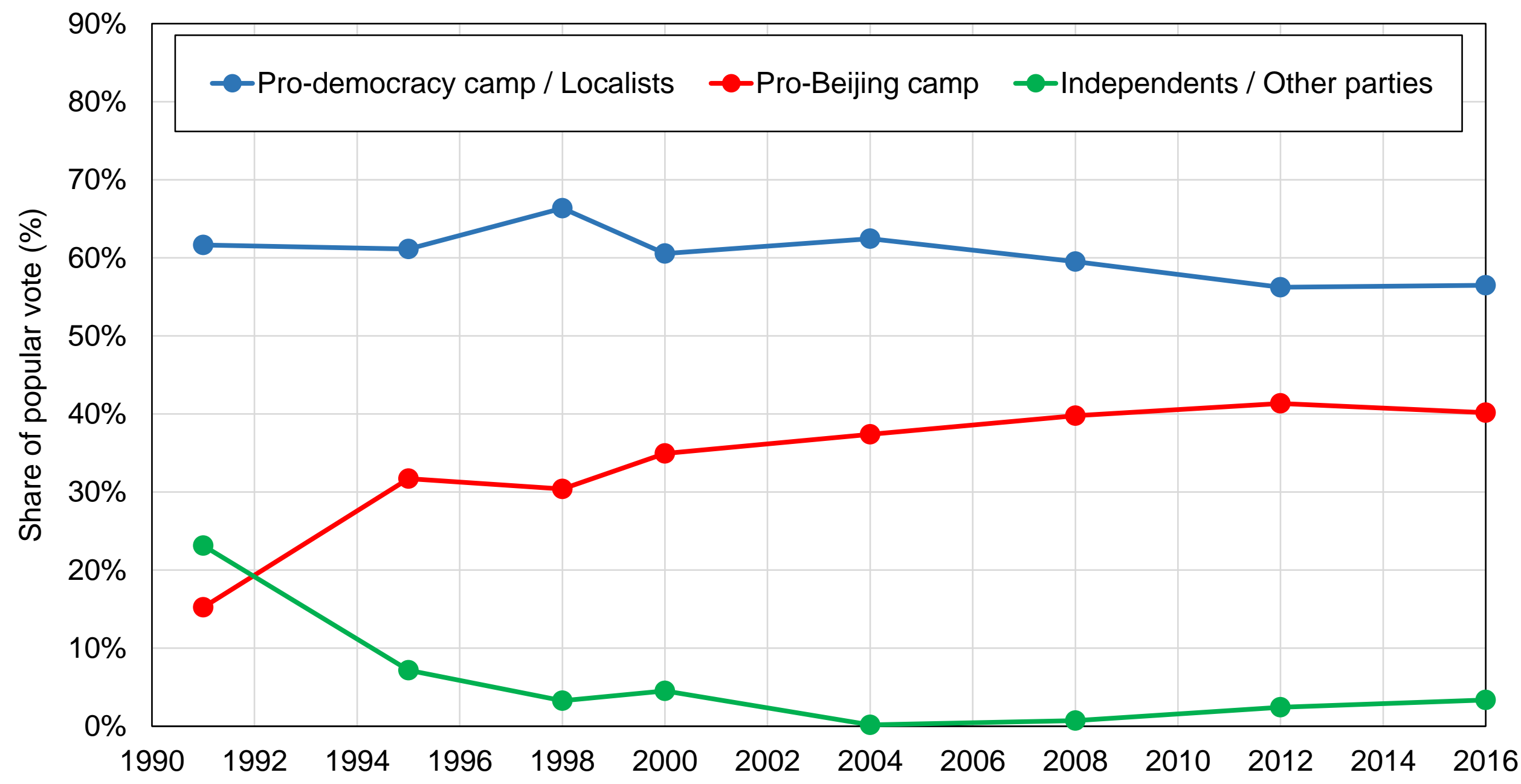

Source: authors' computations using official election results.

Note: the figure shows the share of votes received by selected groups of Hong Kong political parties in geographical constituencies in Legislative Council elections between 1991 and 2016. 


\section{Figure C2 - The rise of generational cleavages in Hong Kong}

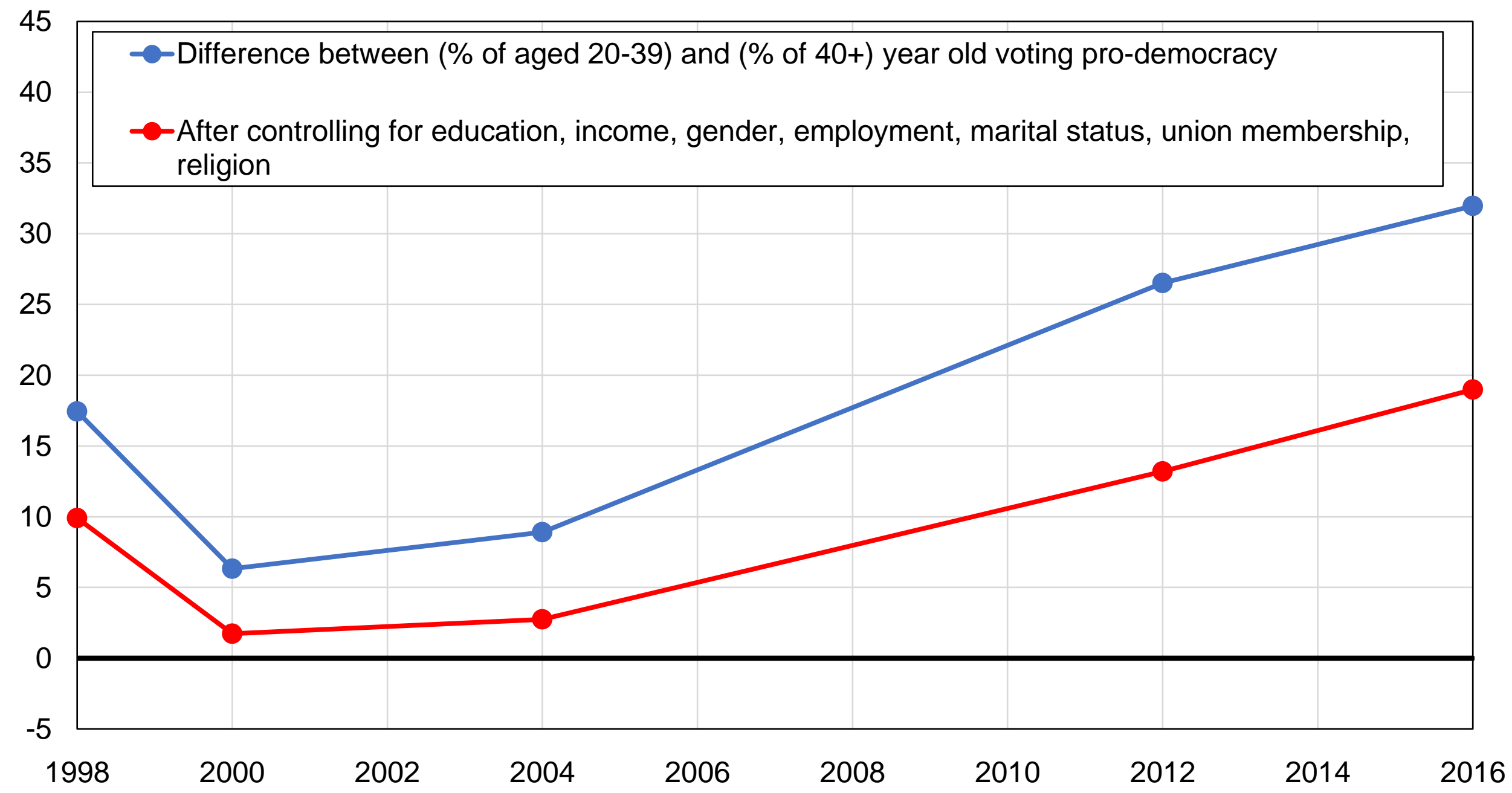

Source: authors' computations using Hong Kong political attitudes surveys.

Note: the figure shows the difference between the share of voters aged 20-39 and the share of voters older than 40 voting for the pro-democracy camp, before and after controlling for other variables. 
Figure C3 - Vote for pro-democracy by decade of birth

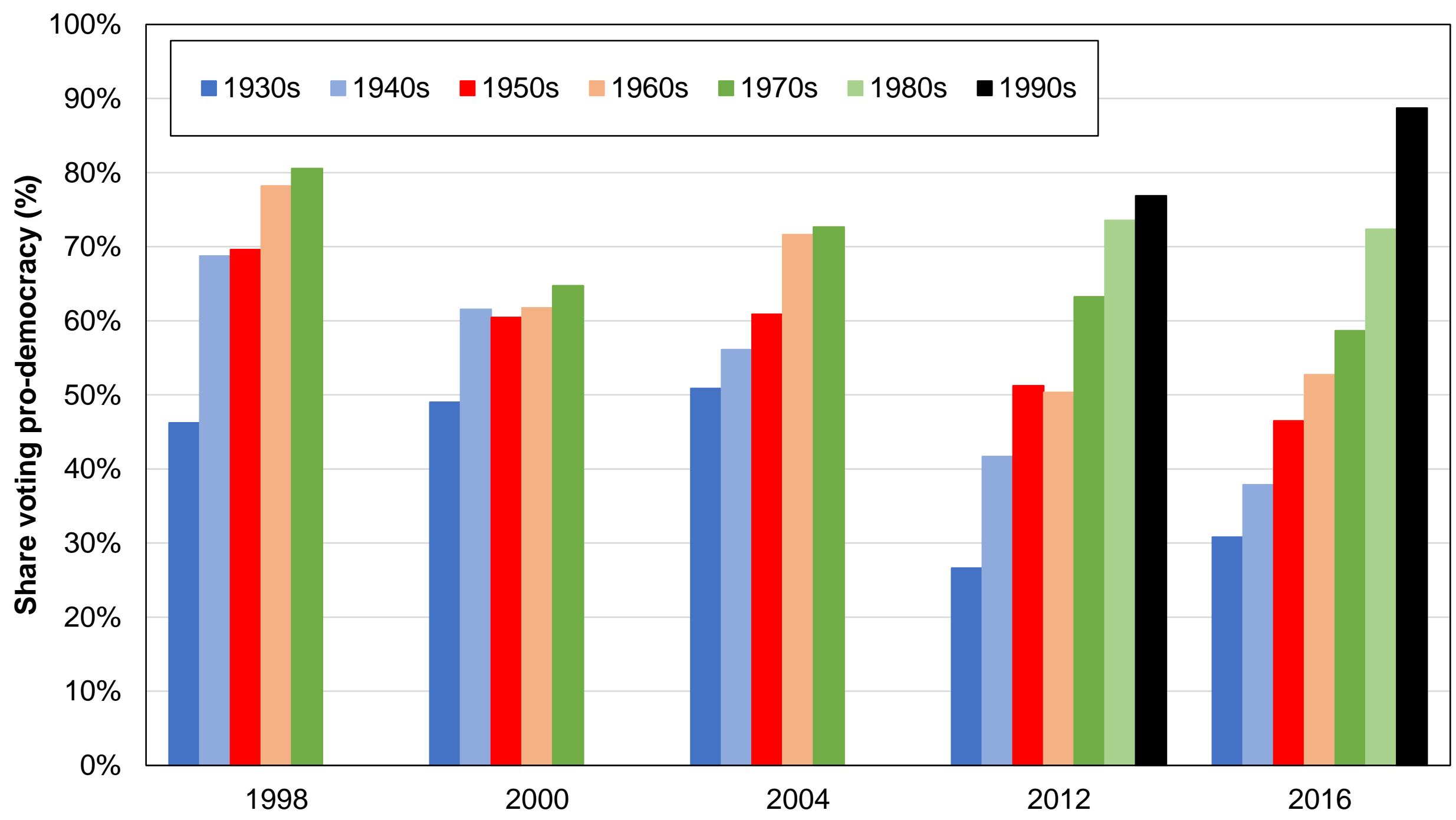

Source: authors' computations using Hong Kong political attitudes surveys.

Note: the figure shows the share of votes received by the pro-democracy camp by decade of birth. 


\section{Figure C4 - The mainlander-native cleavage in Hong Kong}

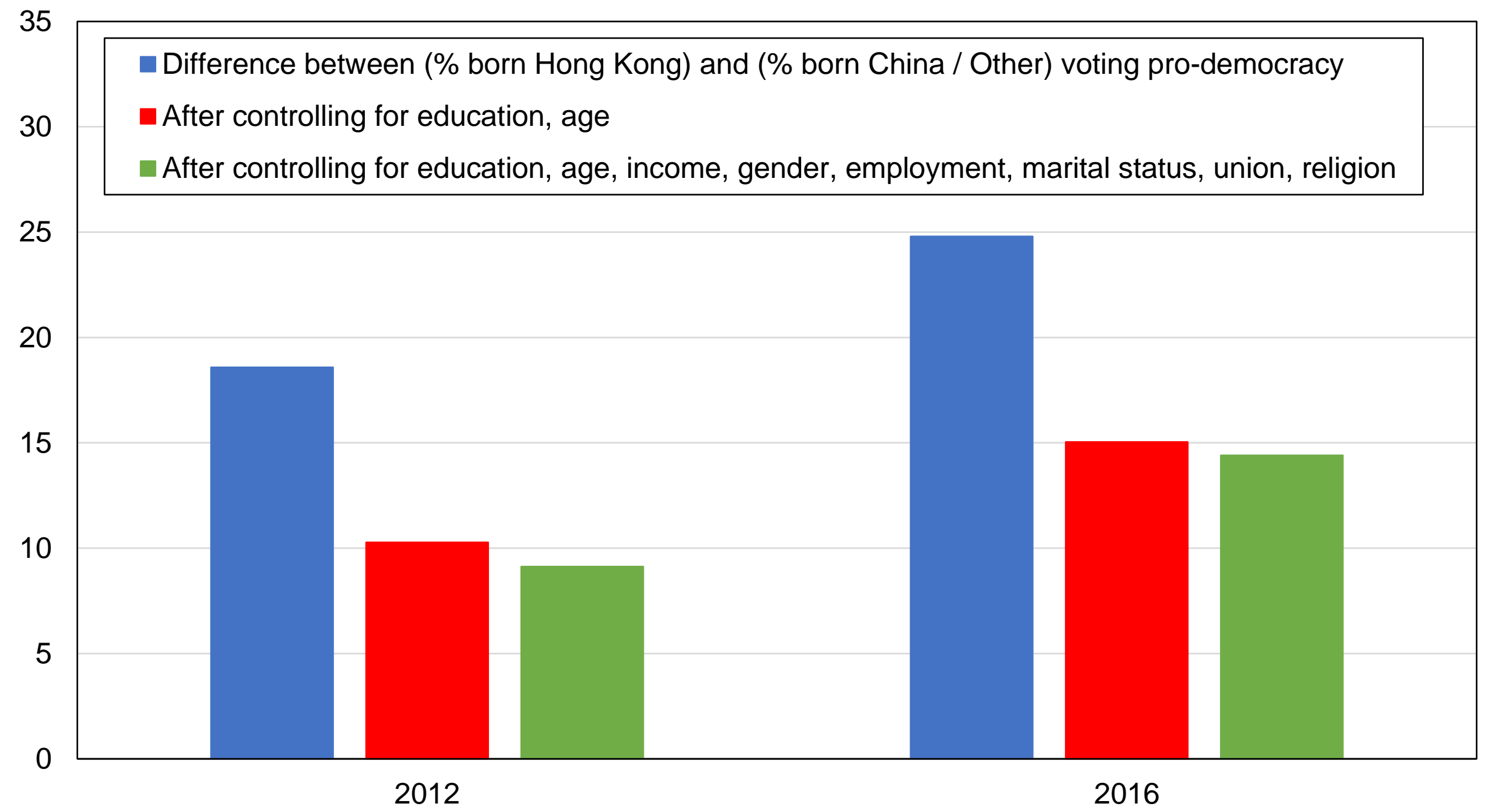

Source: authors' computations using Hong Kong political attitudes surveys.

Note: the figure shows the relative support of voters born in Hong Kong for the pro-democracy camp, before and after controls. 
Figure C5 - Vote for pro-democracy camp among top-income and highest-educated voters

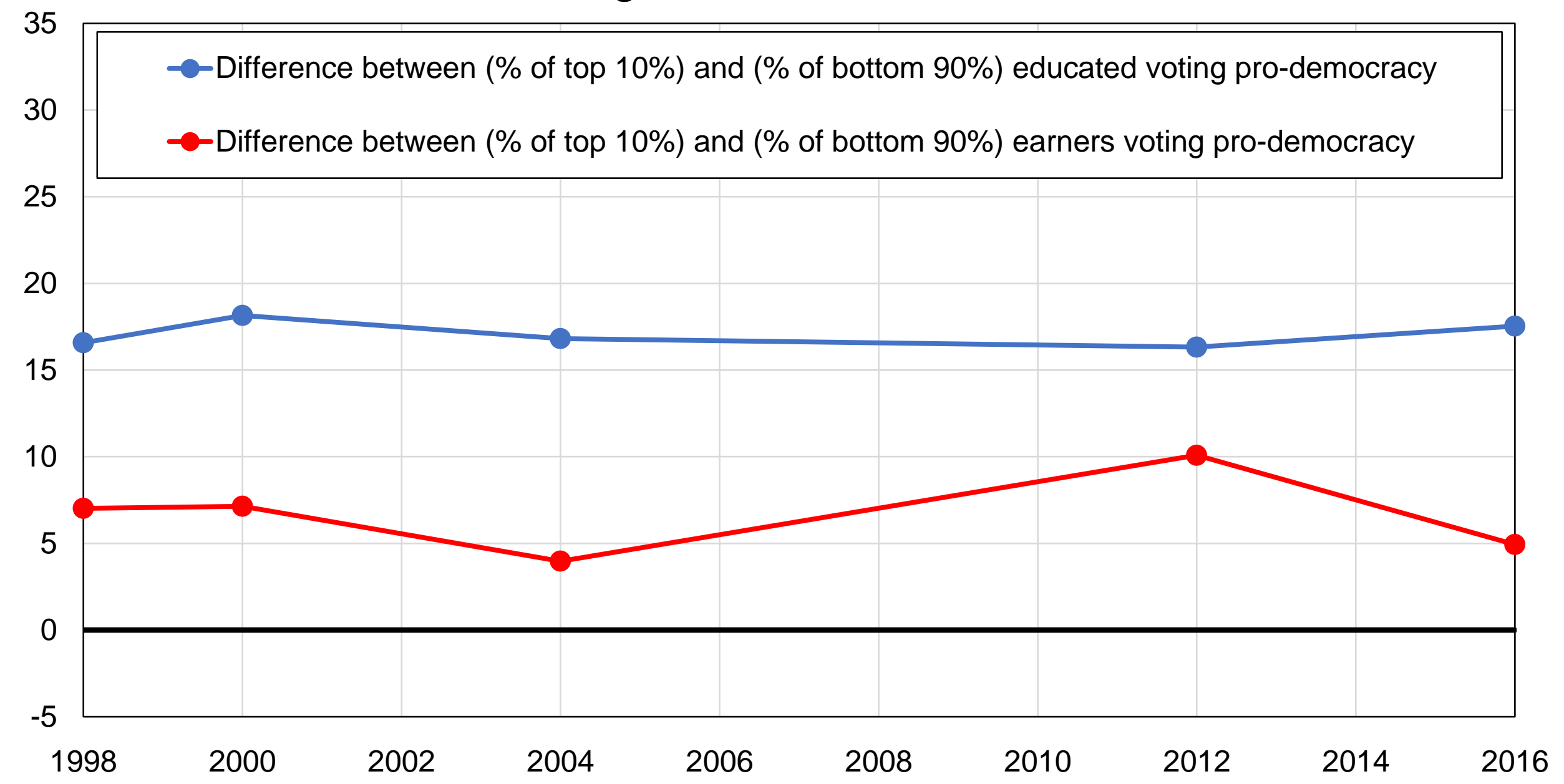

Source: authors' computations using Hong Kong political attitudes surveys.

Note: the figure shows the relative support of highest-educated and top-income voters for the prodemocracy camp. 
Figure C6 - Attitudes towards Hong Kong identity, immigration, and integration with China by age, 2015

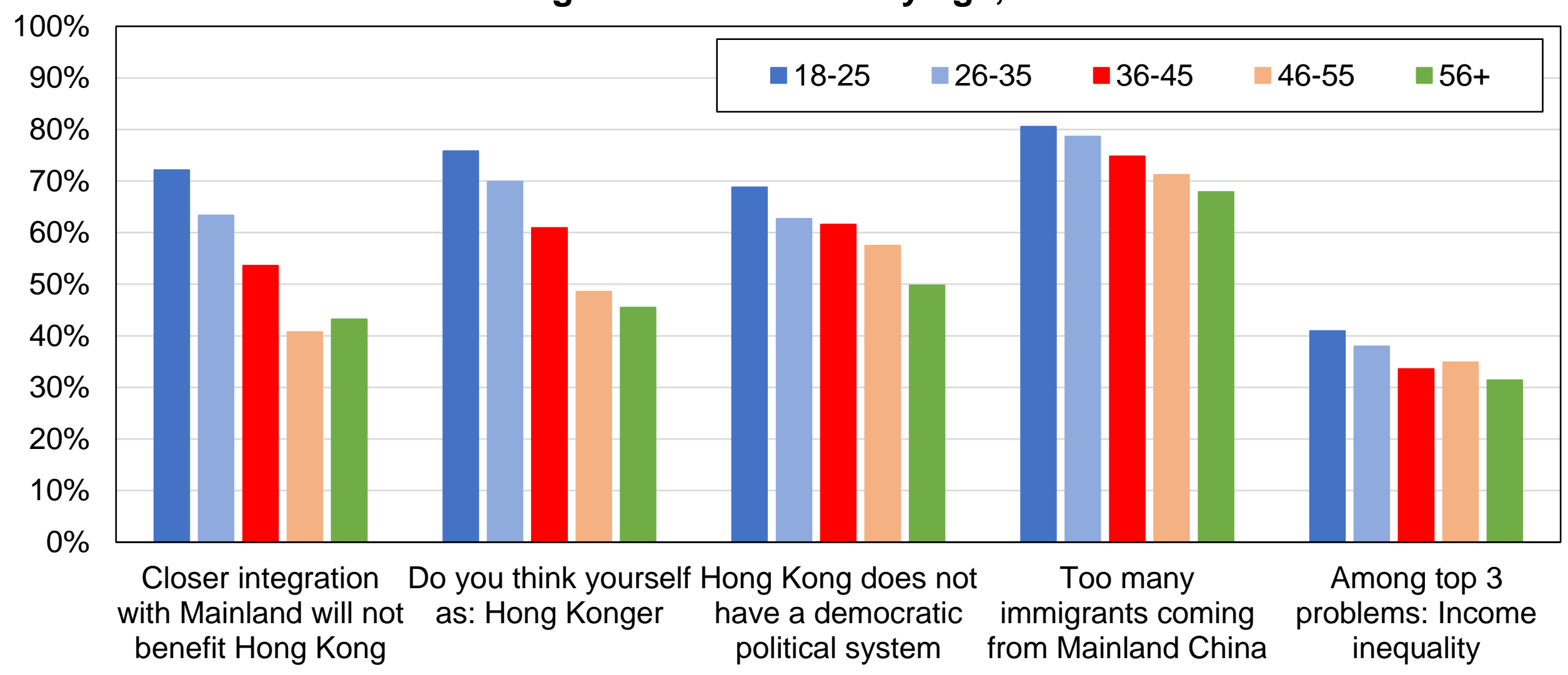

Source: authors' computations using the Hong Kong Election Study 2015.

Note: the figure shows for each age group the share of individuals (1) disagreeing or strongly disagreeing that closer integration with Mainland China will benefit Hong Kong (2) thinking themselves as Hong Konger rather than Chinese, Chinese Hong Konger, Hong Kong Chinese, or Other (3) disagreeing or strongly disagreeing that Hong Kong has a democratic political system (4) agreeing or strongly agreeing that Hong Kong has too many immigrants coming from Mainland China (5) declaring income inequality as one of the three most important problems facing Hong Kong at the present time. 
Figure C7 - The structure of the electorate by education

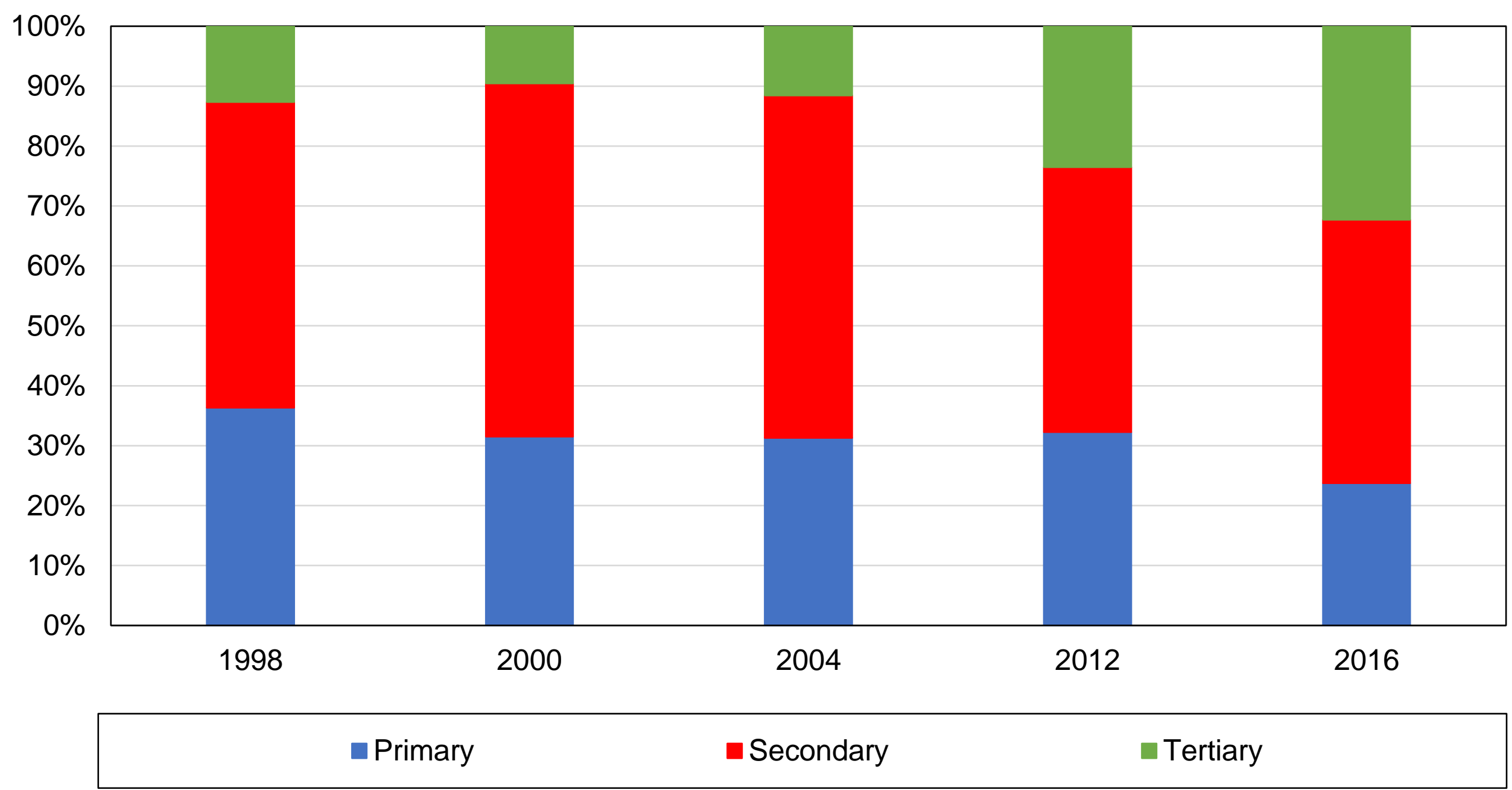

Source: authors' computations using Hong Kong political attitudes surveys.

Note: the figure shows the distribution of education levels of the Hong Kong adult population and its evolution over time. 
Figure C8 - The structure of the electorate by age group

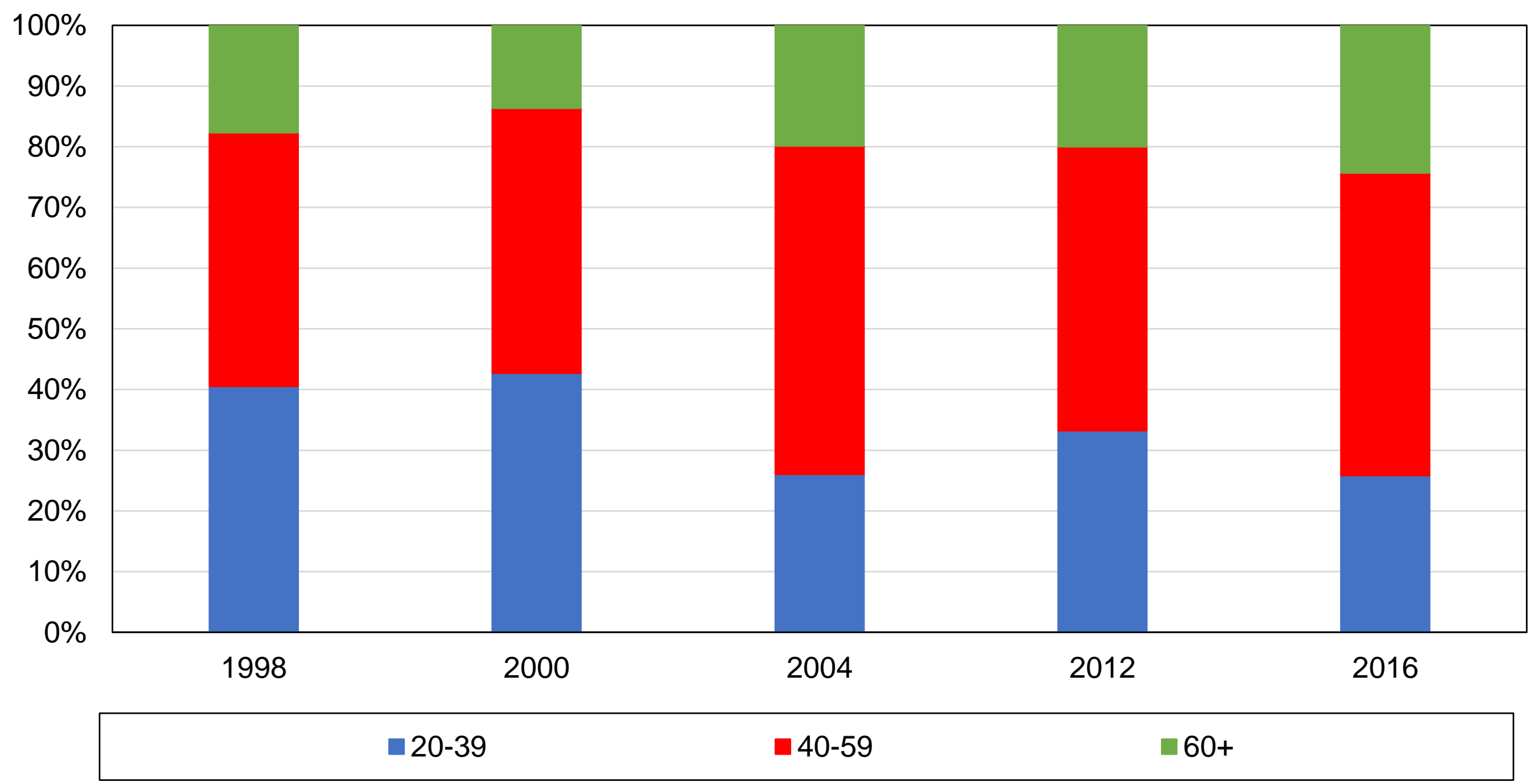

Source: authors' computations using Hong Kong political attitudes surveys.

Note: the figure shows the distribution of age groups in the Hong Kong adult population and its evolution over time. 
Figure C9 - Educational composition of income quintiles, 1998

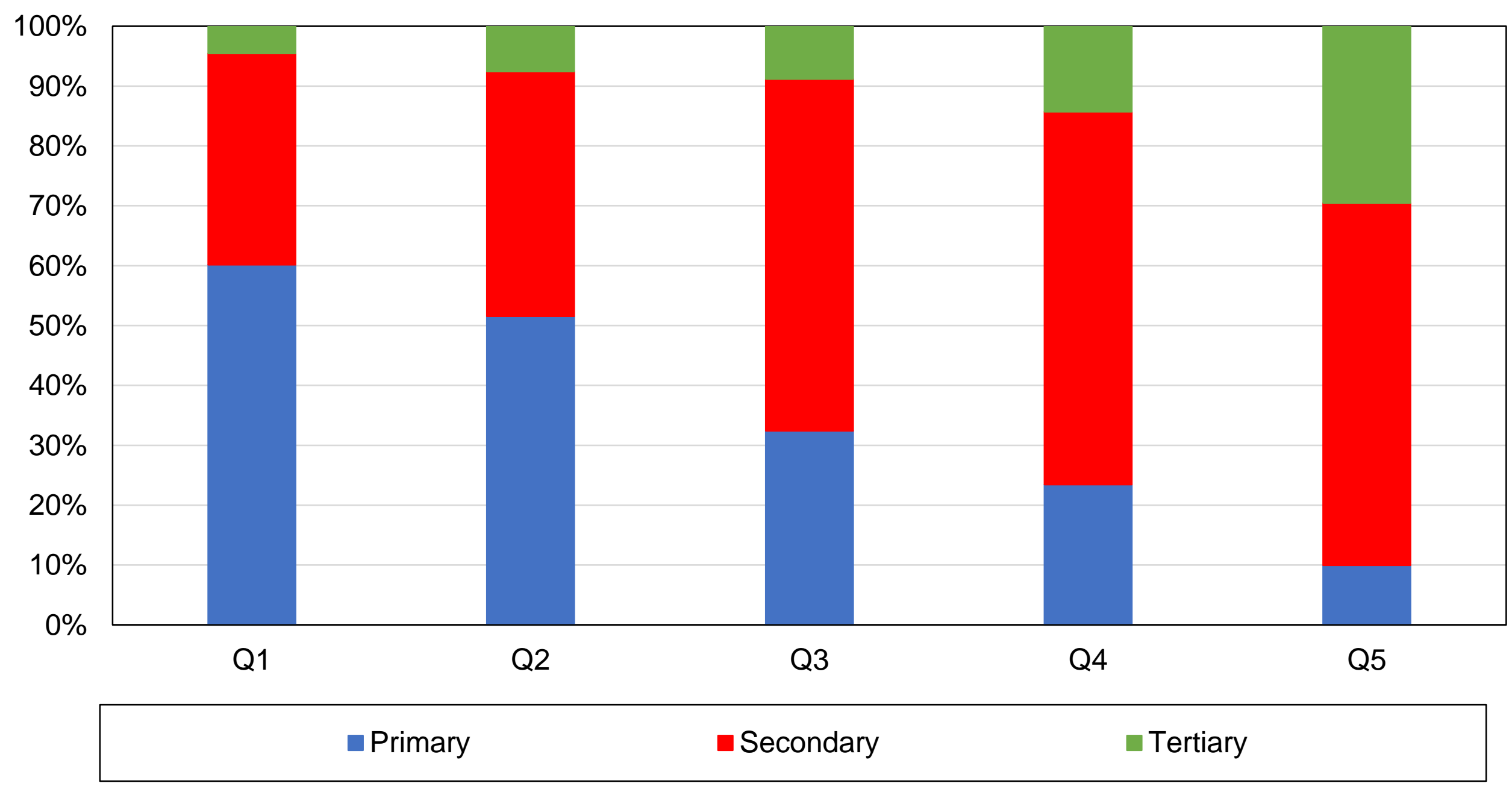

Source: authors' computations using Hong Kong political attitudes surveys.

Note: the figure shows the distribution of income quintiles by education level of the Hong Kong adult population in 1998. 
Figure C9b - Educational composition of income quintiles, 2016

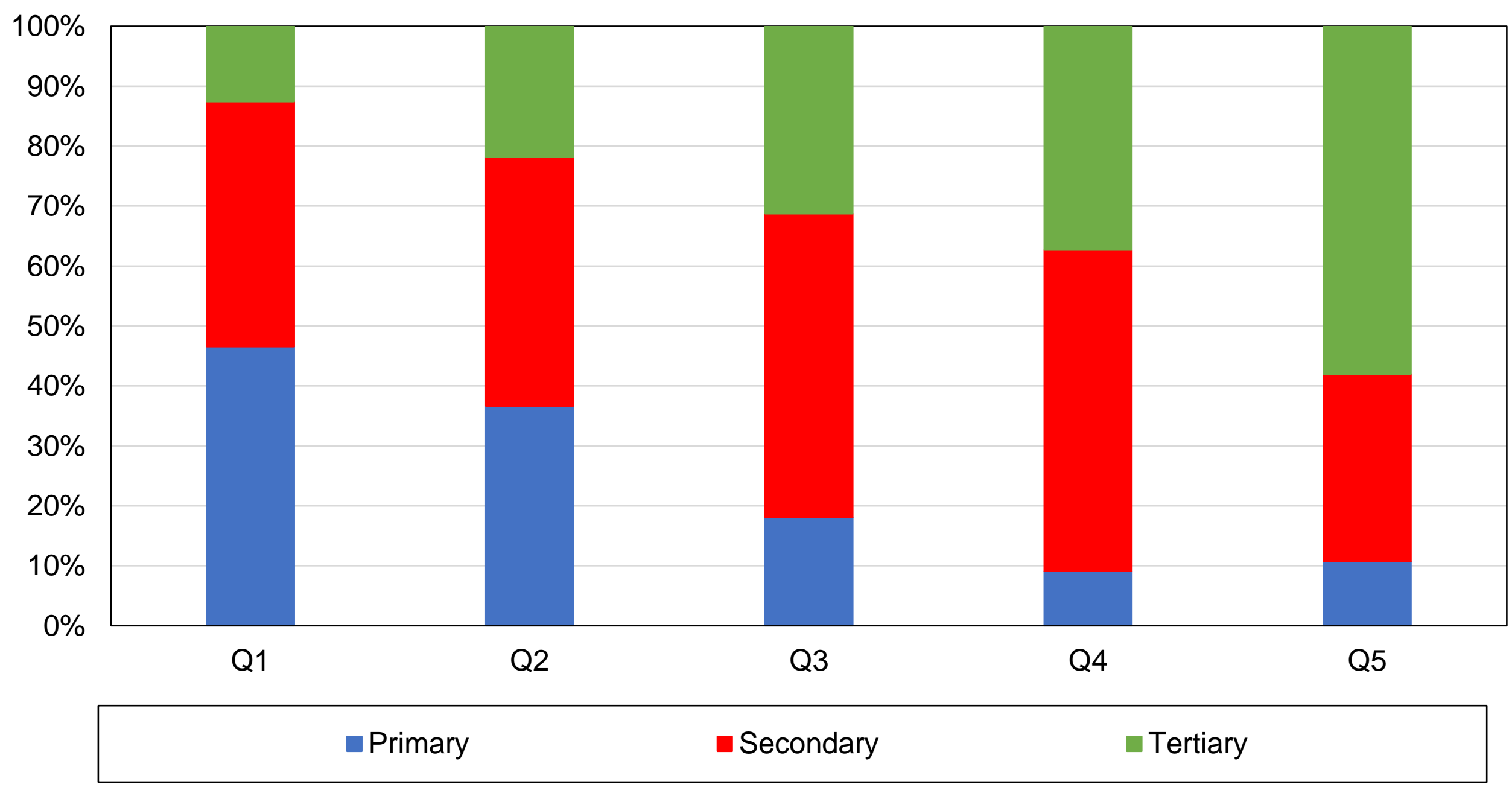

Source: authors' computations using Hong Kong political attitudes surveys.

Note: the figure shows the distribution of income quintiles by education level of the Hong Kong adult population in 2016. 


\section{Figure C10 - Vote for pro-democracy camp by education level}

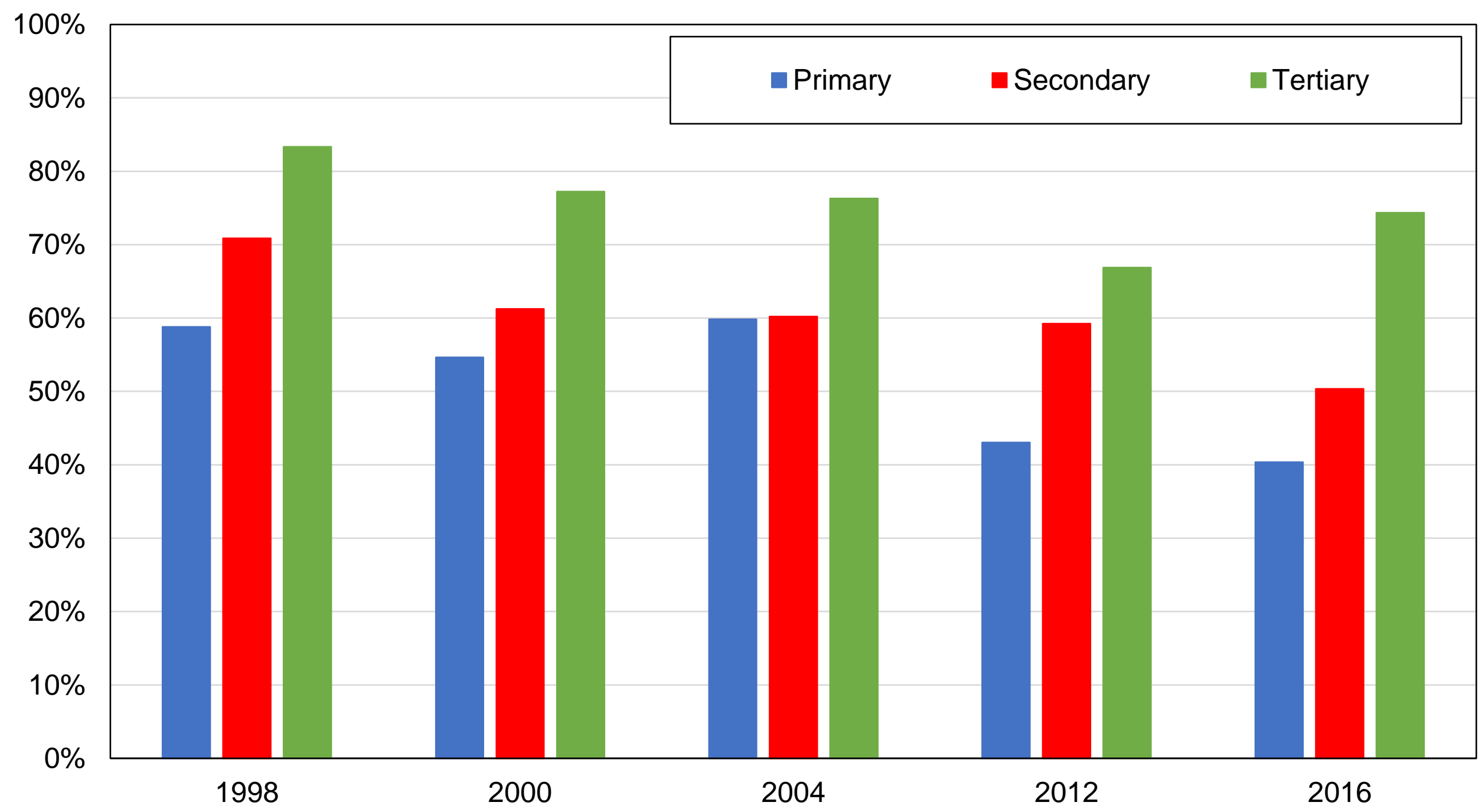

Source: authors' computations using Hong Kong political attitudes surveys.

Note: the figure shows the share of votes received by the pro-democracy camp by education level. 
Figure C11 - Vote for pro-democracy camp by education group

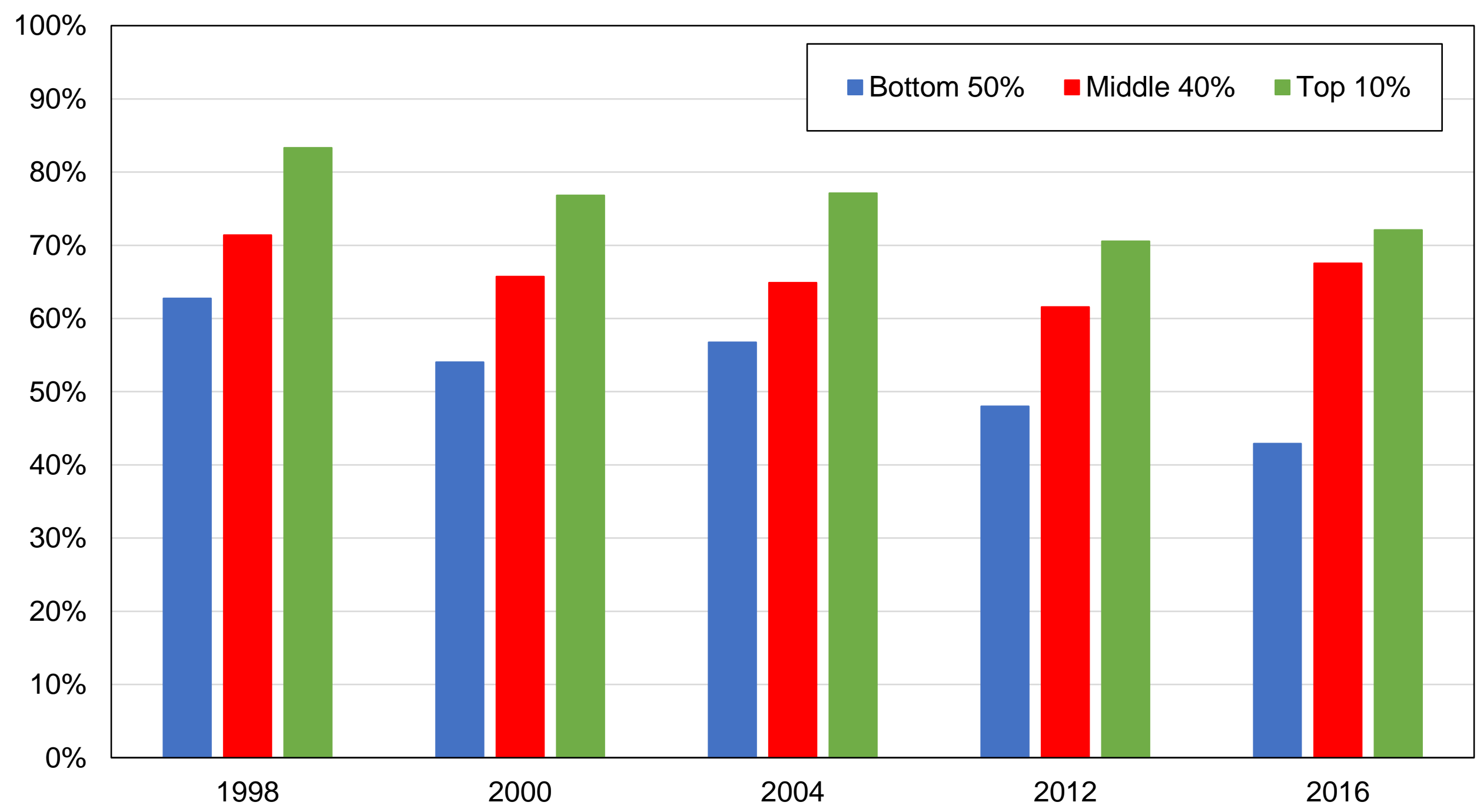

Source: authors' computations using Hong Kong political attitudes surveys.

Note: the figure shows the share of votes received by the pro-democracy camp by education group. 
Figure C2 - Vote for pro-democracy camp by age group

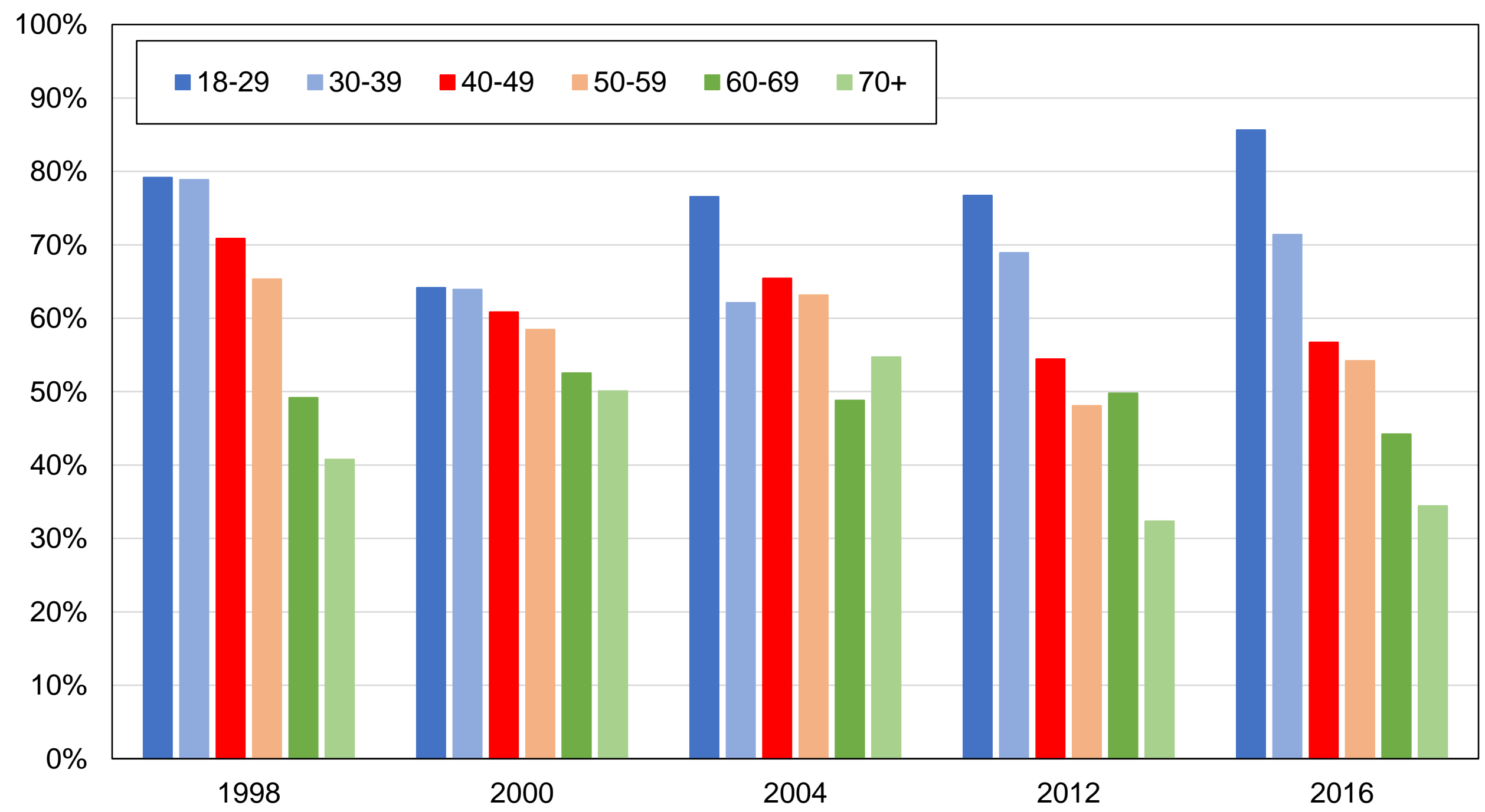

Source: authors' computations using Hong Kong political attitudes surveys.

Note: the figure shows the share of votes received by the pro-democracy camp by age group. 
Figure C12 - Vote for pro-democracy camp by income quintile

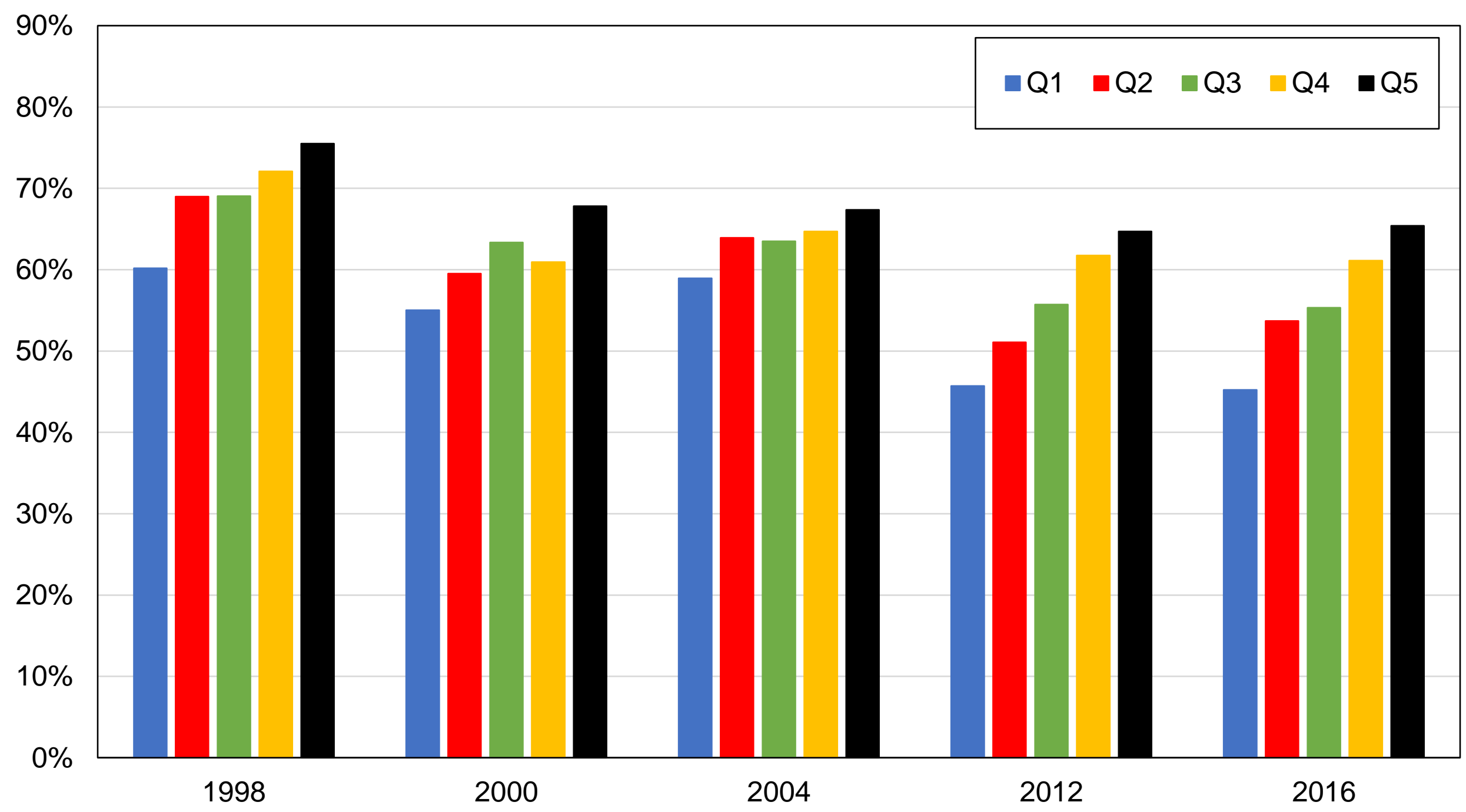

Source: authors' computations using Hong Kong political attitudes surveys.

Note: the figure shows the share of votes received by the pro-democracy camp by income quintile. 
Figure $\mathrm{C} 12 \mathrm{~b}$ - Vote for pro-democracy camp by income quintile

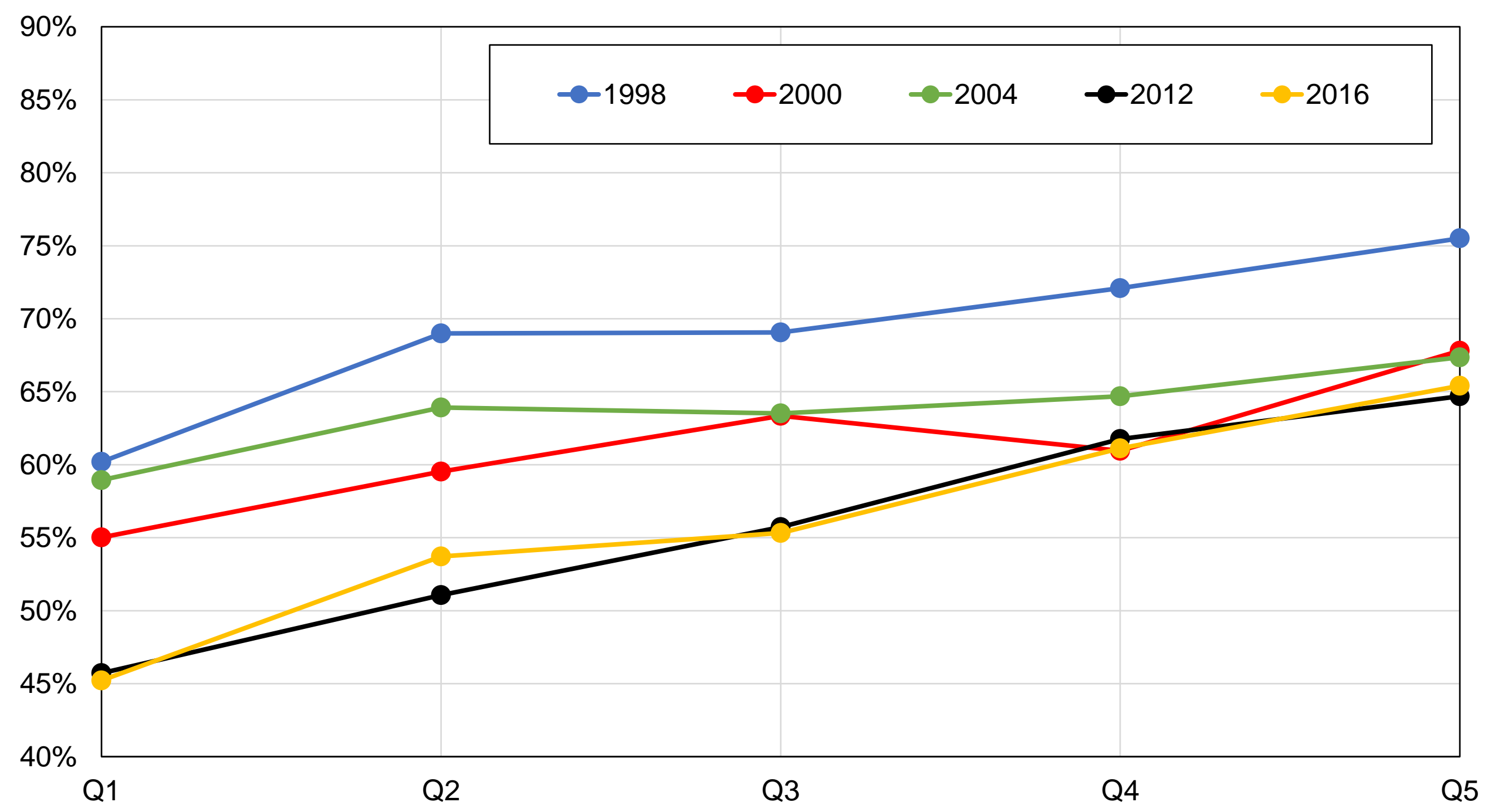

Source: authors' computations using Hong Kong political attitudes surveys.

Note: the figure shows the share of votes received by the pro-democracy camp by income quintile. 
Figure C13 - Vote for pro-democracy camp by location of birth

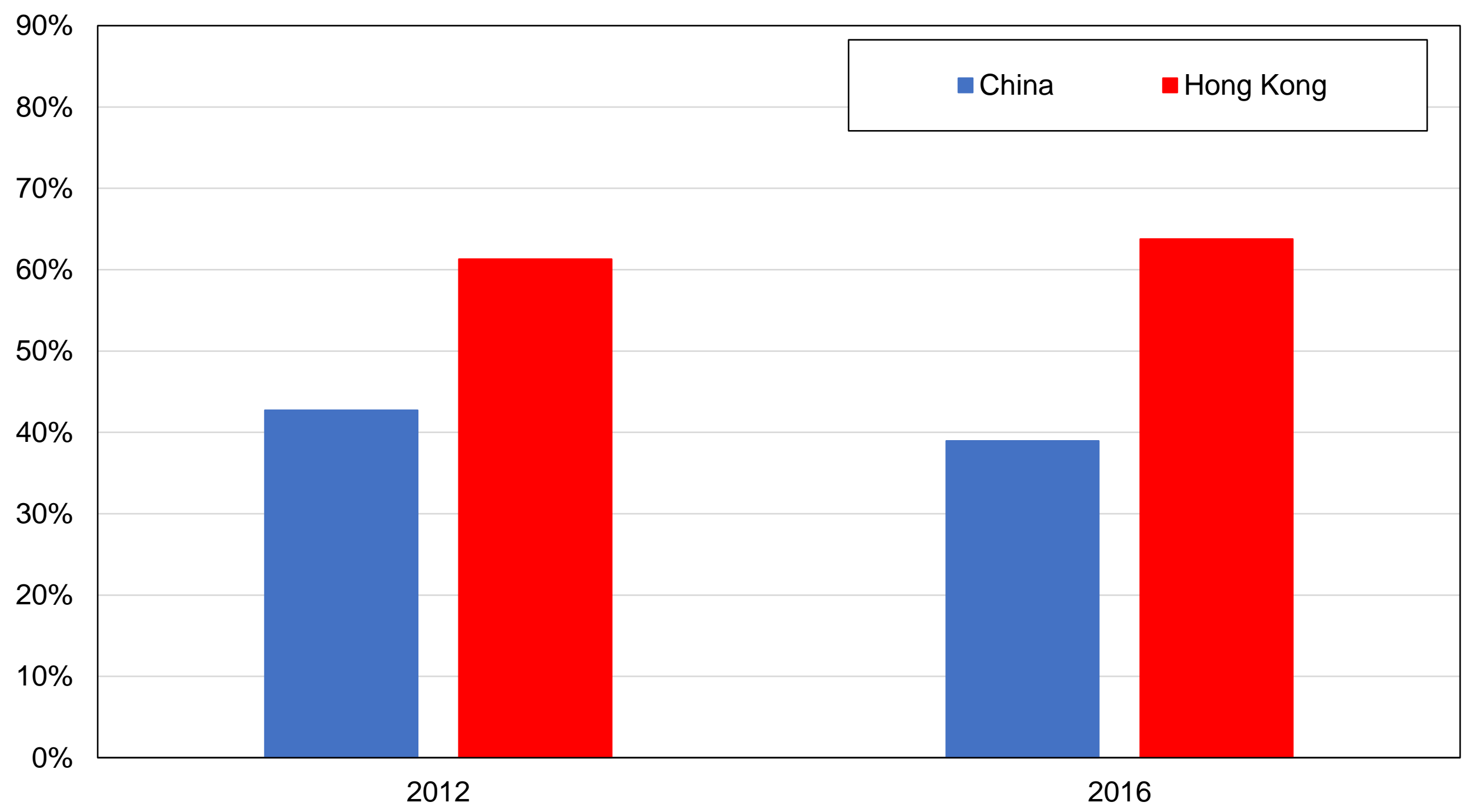

Source: authors' computations using Hong Kong political attitudes surveys.

Note: the figure shows the share of votes received by the pro-democracy camp by location of birth. 
Figure C14 - Vote for pro-democracy camp by income group

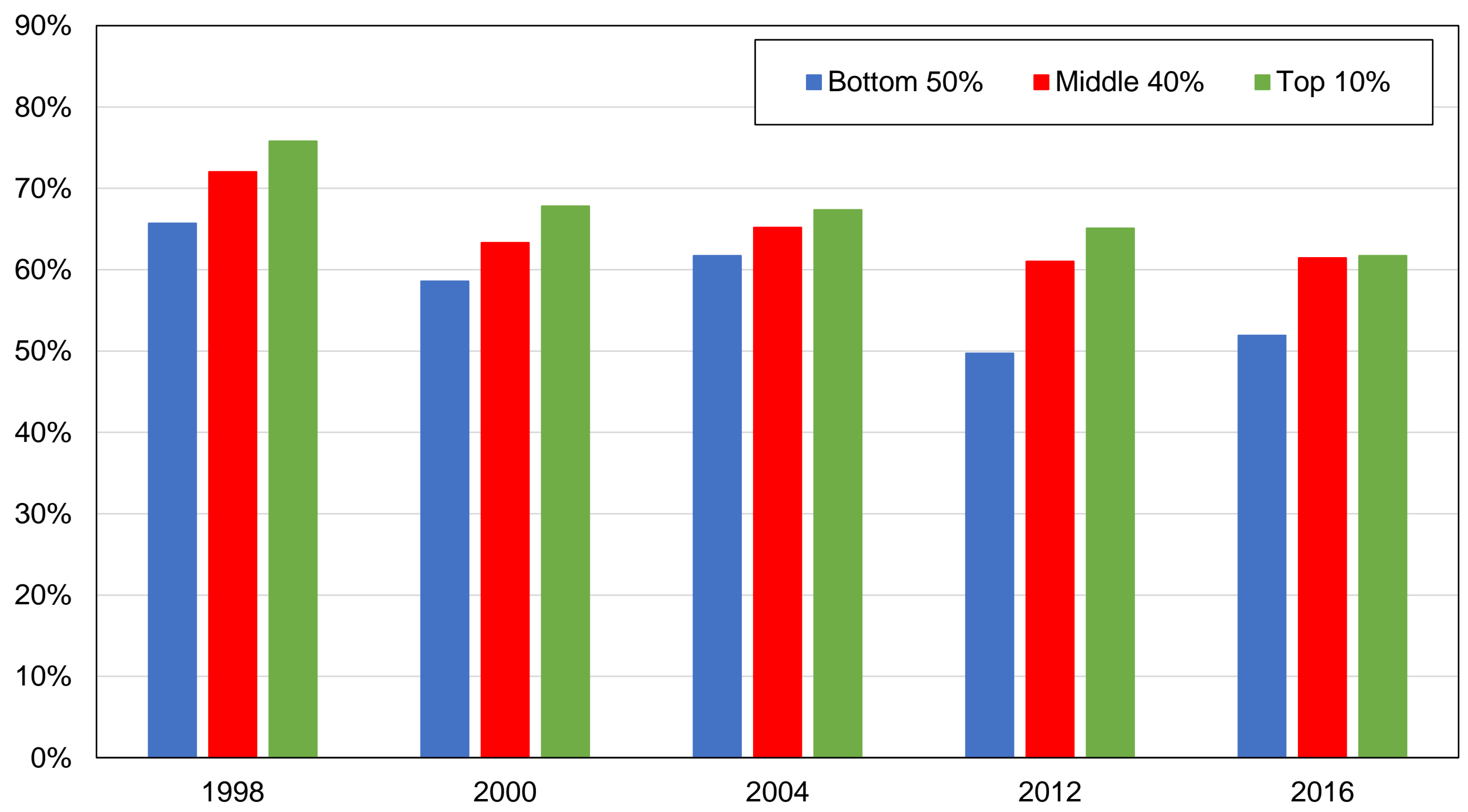

Source: authors' computations using Hong Kong political attitudes surveys.

Note: the figure shows the share of votes received by the pro-democracy camp by income group. 
Figure C15 - Vote for pro-democracy camp by union membership

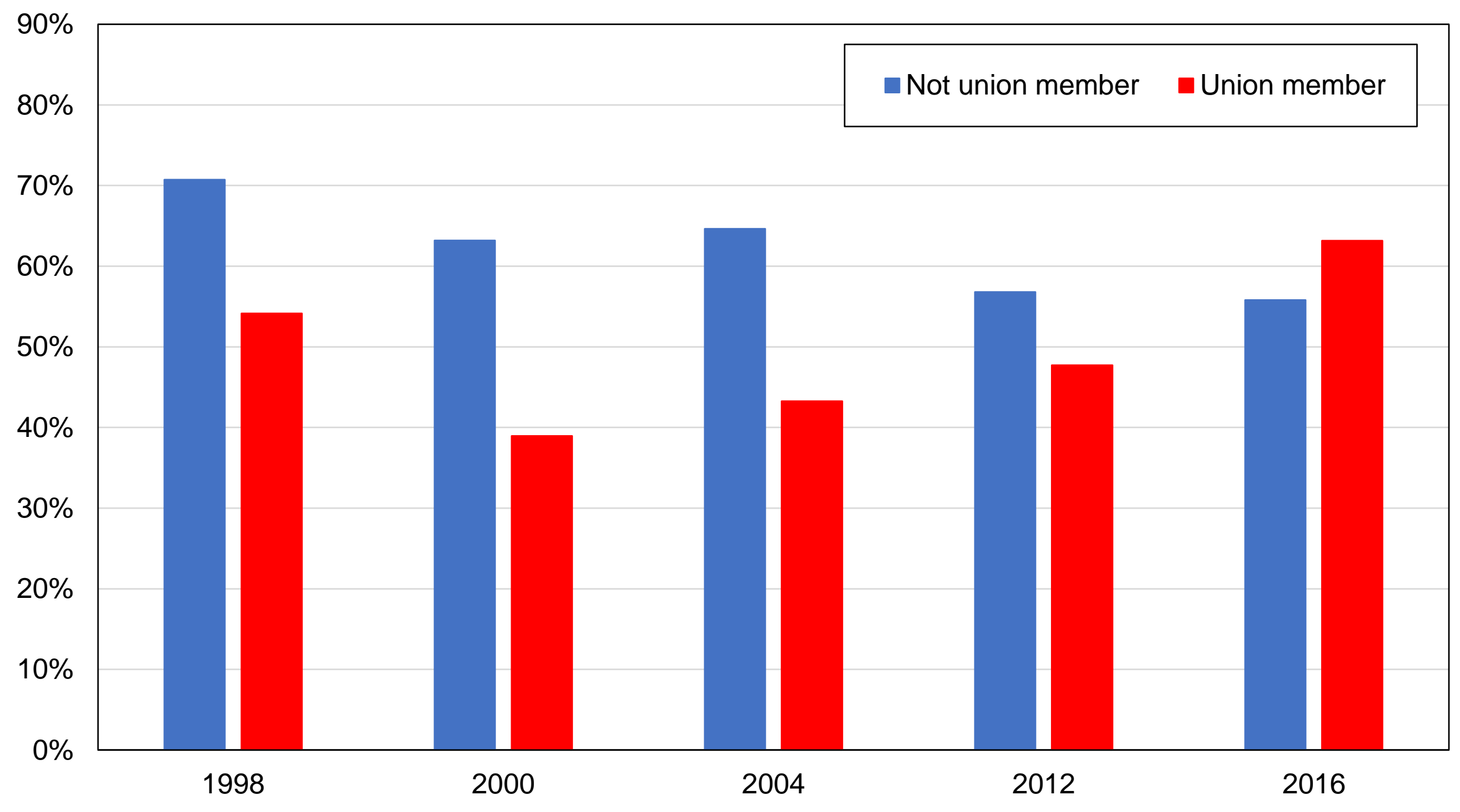

Source: authors' computations using Hong Kong political attitudes surveys.

Note: the figure shows the share of votes received by the pro-democracy camp by union membership. 
Figure C16 - Vote for pro-democracy camp by gender

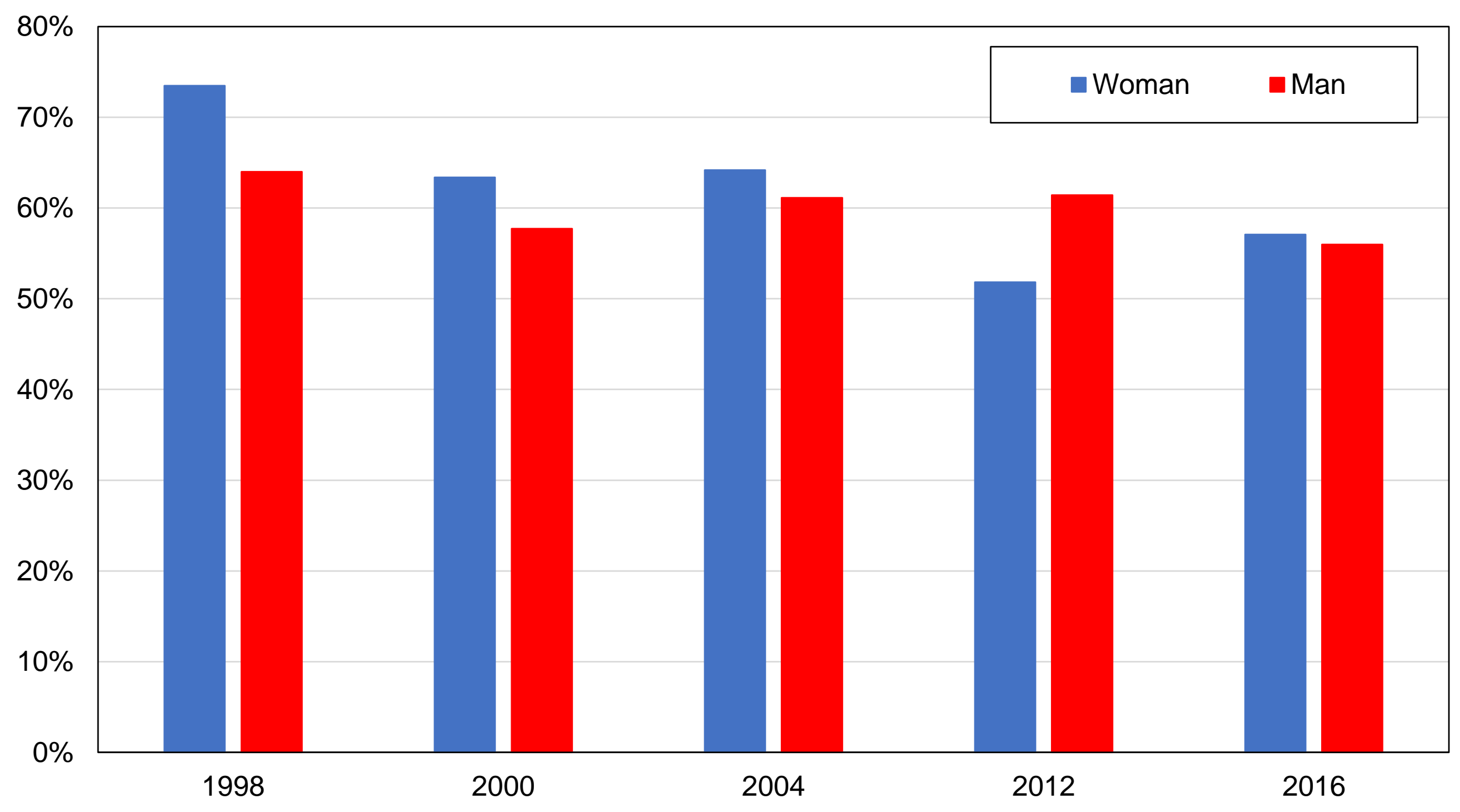

Source: authors' computations using Hong Kong political attitudes surveys.

Note: the figure shows the share of votes received by the pro-democracy camp by gender. 
Figure C17 - Vote for pro-democracy camp by religion

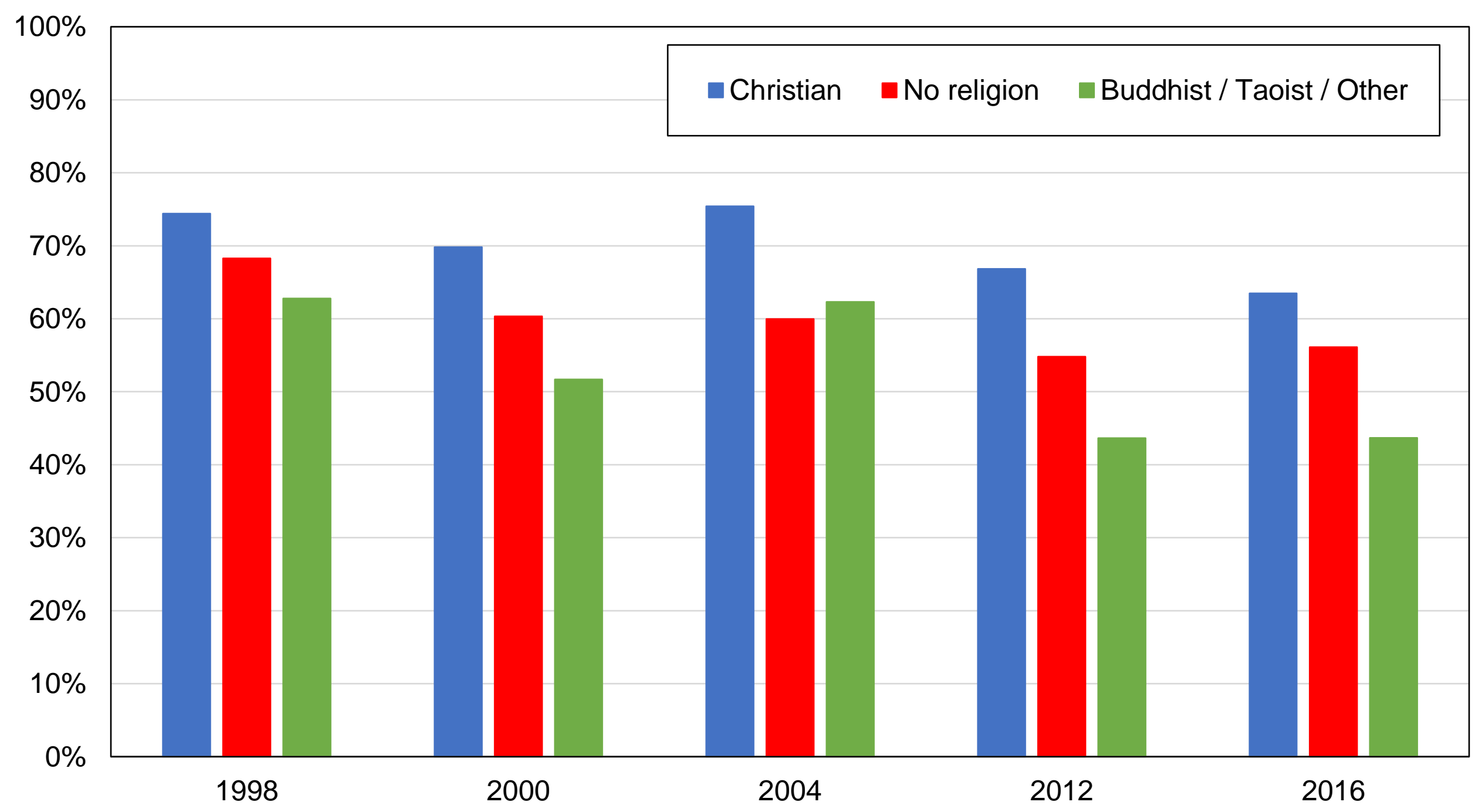

Source: authors' computations using Hong Kong political attitudes surveys.

Note: the figure shows the share of votes received by the pro-democracy camp by religious affiliation. 
Figure C18 - Vote for pro-democracy camp by employment status

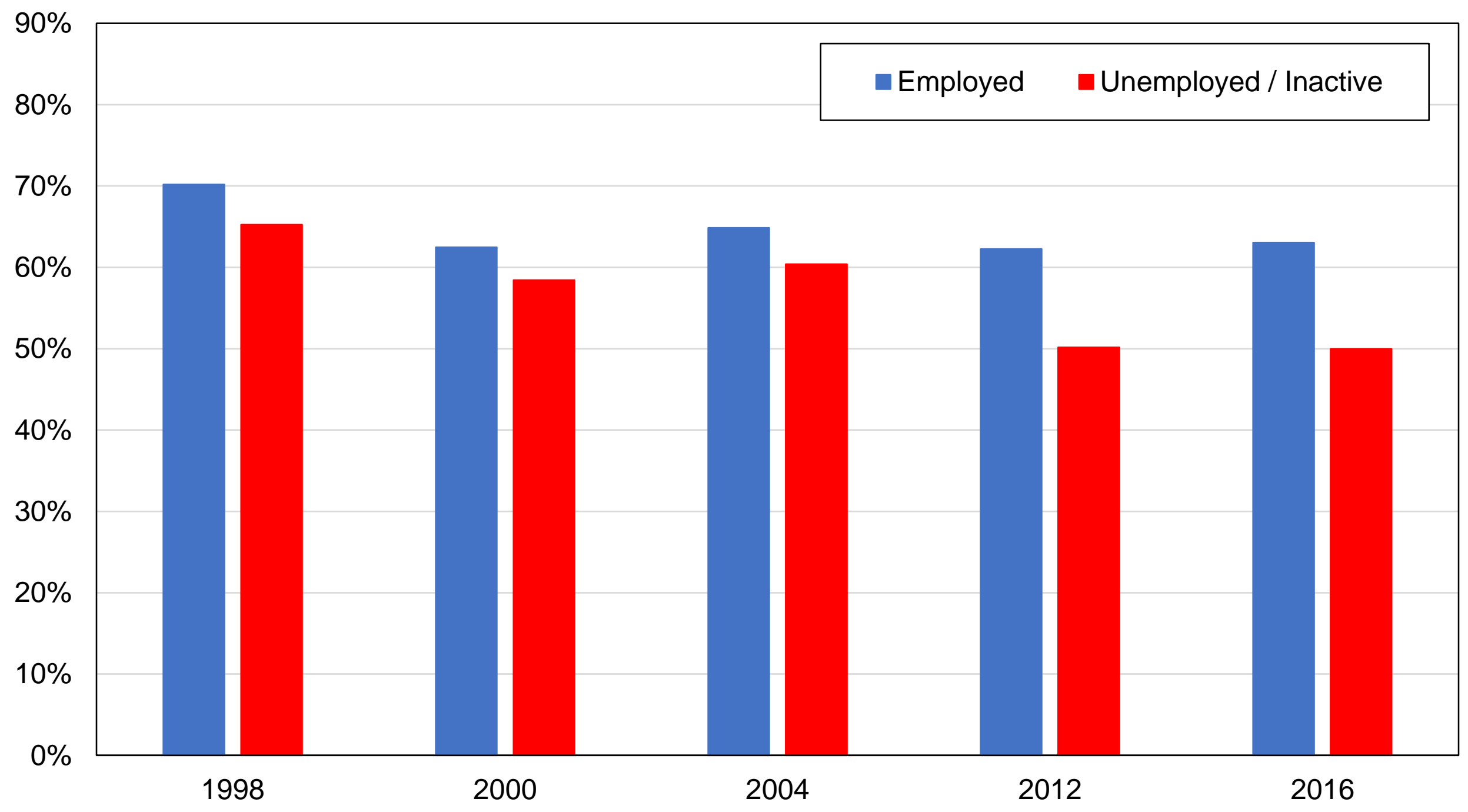

Source: authors' computations using Hong Kong political attitudes surveys.

Note: the figure shows the share of votes received by the pro-democracy camp by employment status. 
Figure C19 - Vote for pro-democracy camp by marital status

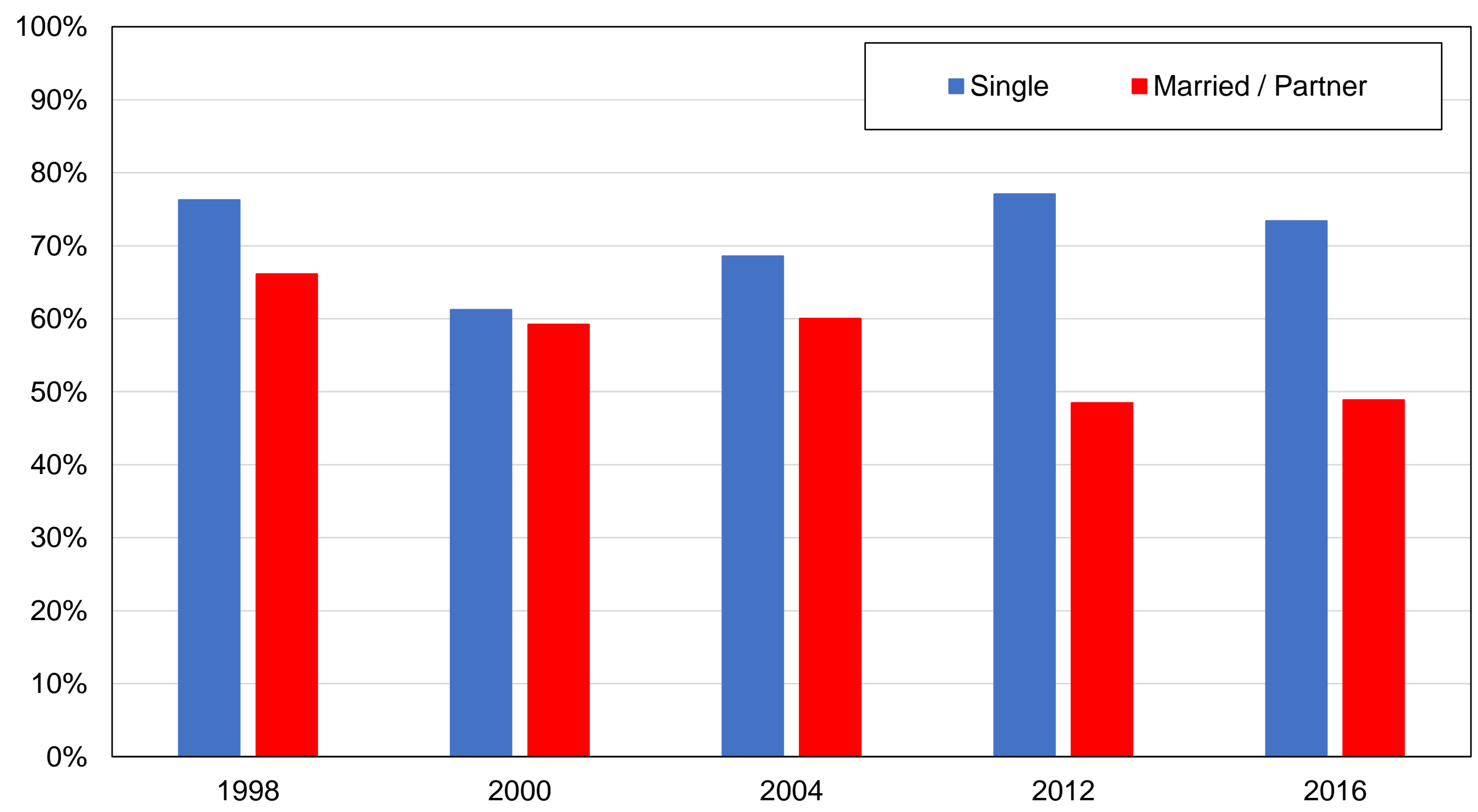

Source: authors' computations using Hong Kong political attitudes surveys.

Note: the figure shows the share of votes received by the pro-democracy camp by marital status. 
Figure C20 - Vote for pro-democracy camp among top-income and highest-educated voters

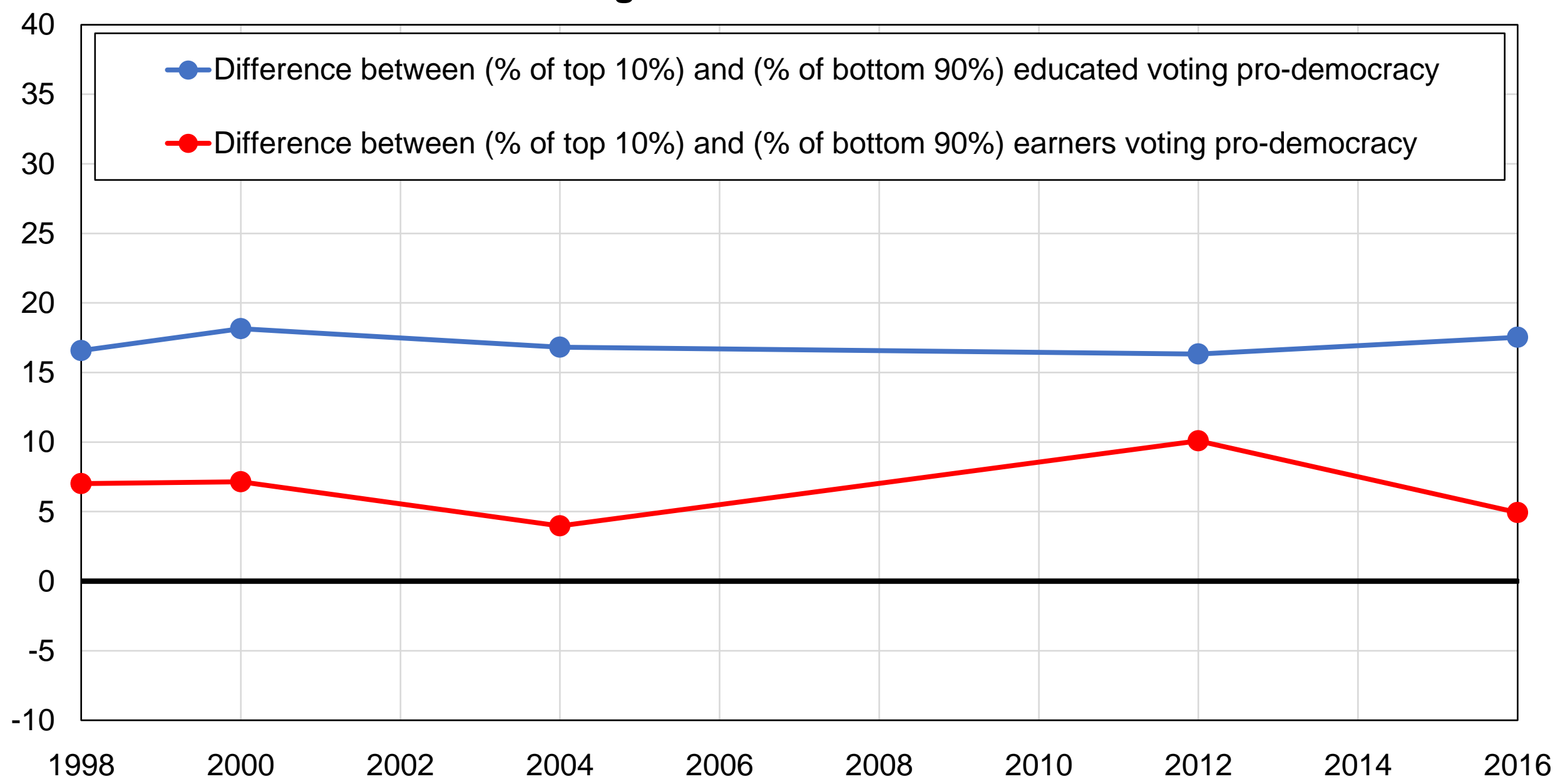

Source: authors' computations using Hong Kong political attitudes surveys.

Note: the figure shows the relative support of highest-educated and top-income voters for the prodemocracy camp. 


\section{Figure C21 - Vote for pro-democracy among highest-educated voters}

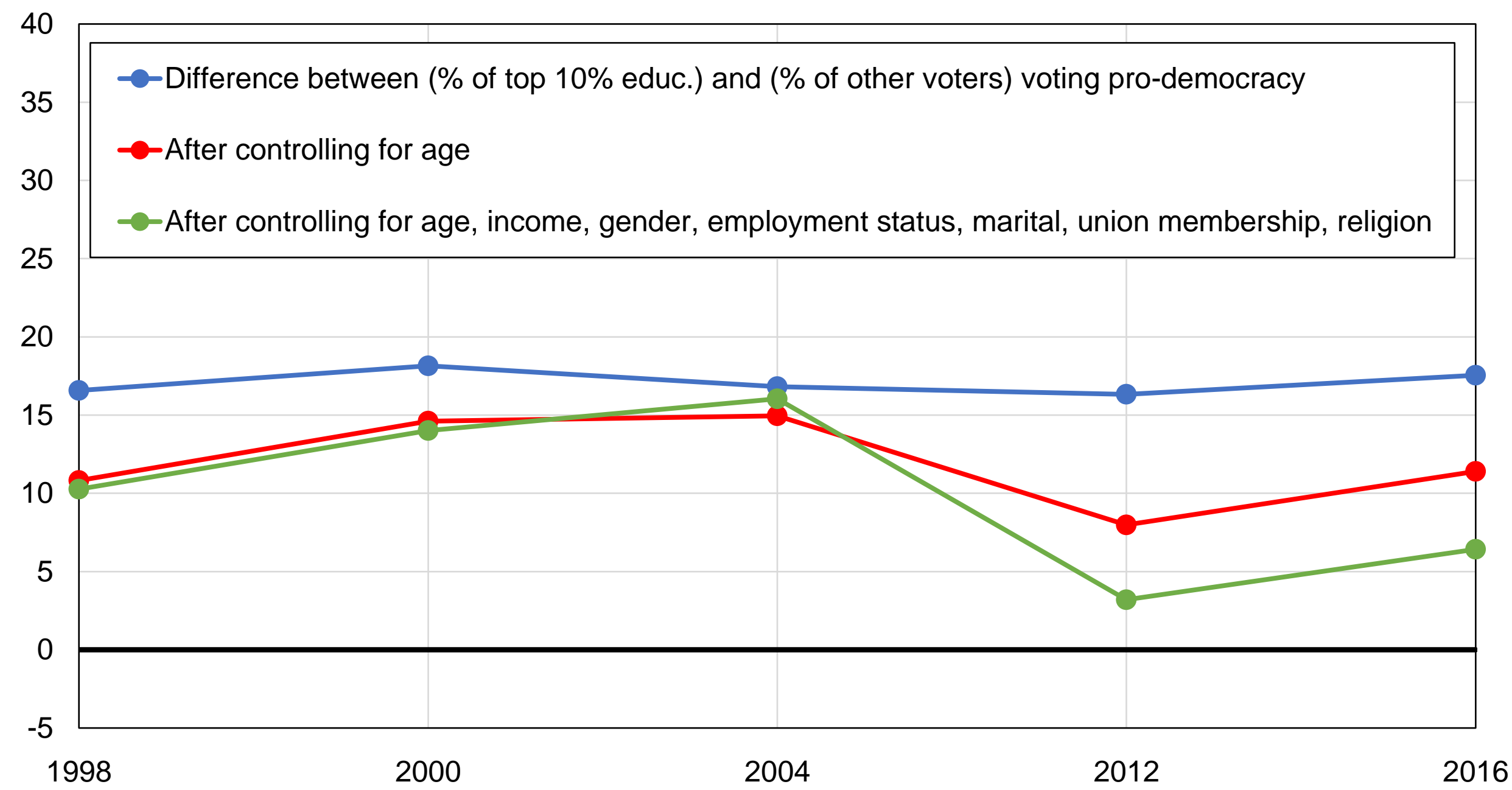

Source: authors' computations using Hong Kong political attitudes surveys.

Note: the figure shows the difference between the share of top $10 \%$ educated voters and the share of other voters voting for the pro-democracy camp, before and after controlling for other variables. 


\section{Figure C22 - Vote for pro-democracy among lowest-educated voters}

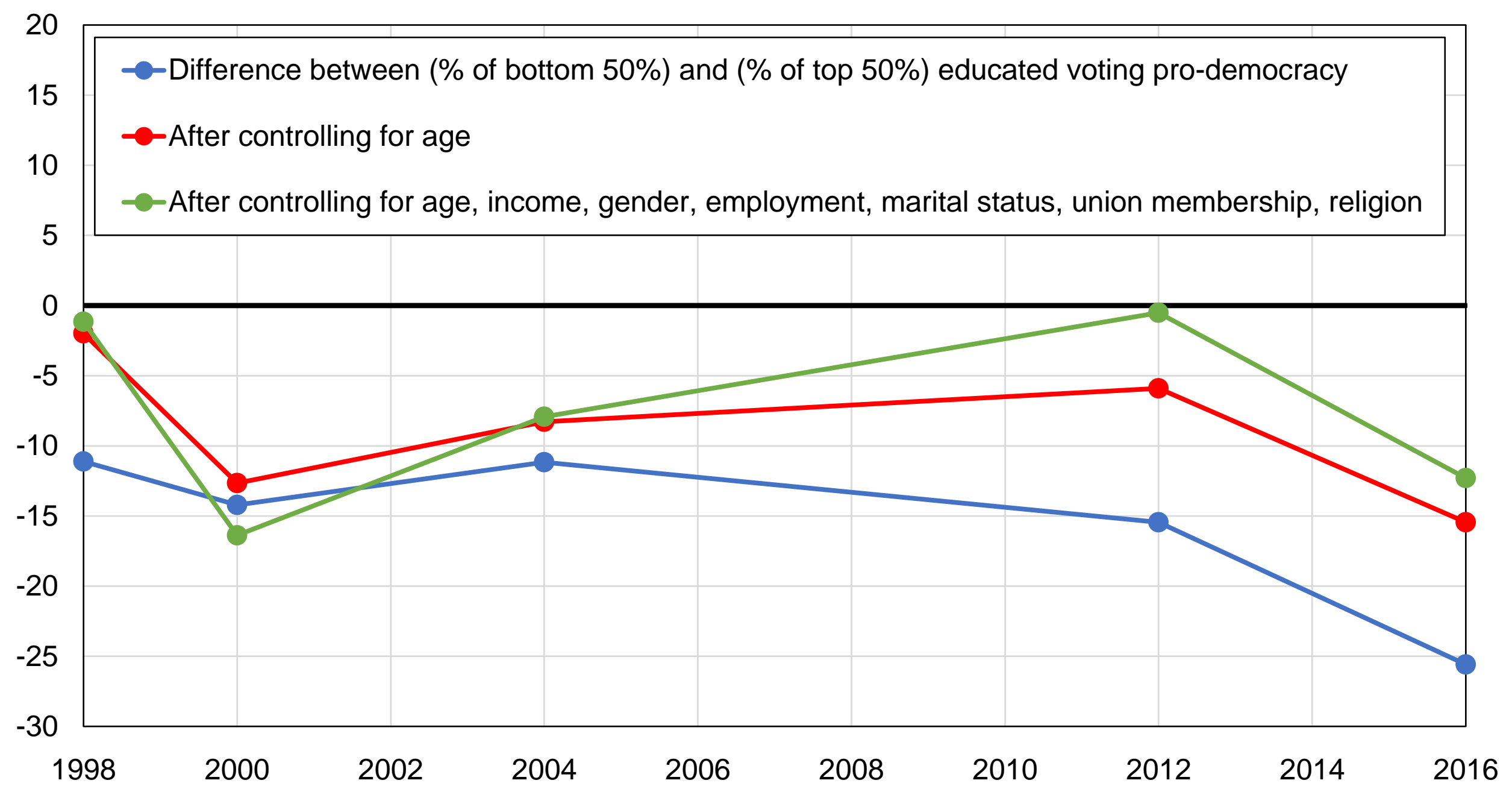

Source: authors' computations using Hong Kong political attitudes surveys.

Note: the figure shows the difference between the share of bottom $50 \%$ educated voters and the share of other voters voting for the pro-democracy camp, before and after controlling for other variables. 


\section{Figure C23 - Vote for pro-democracy among university graduates}

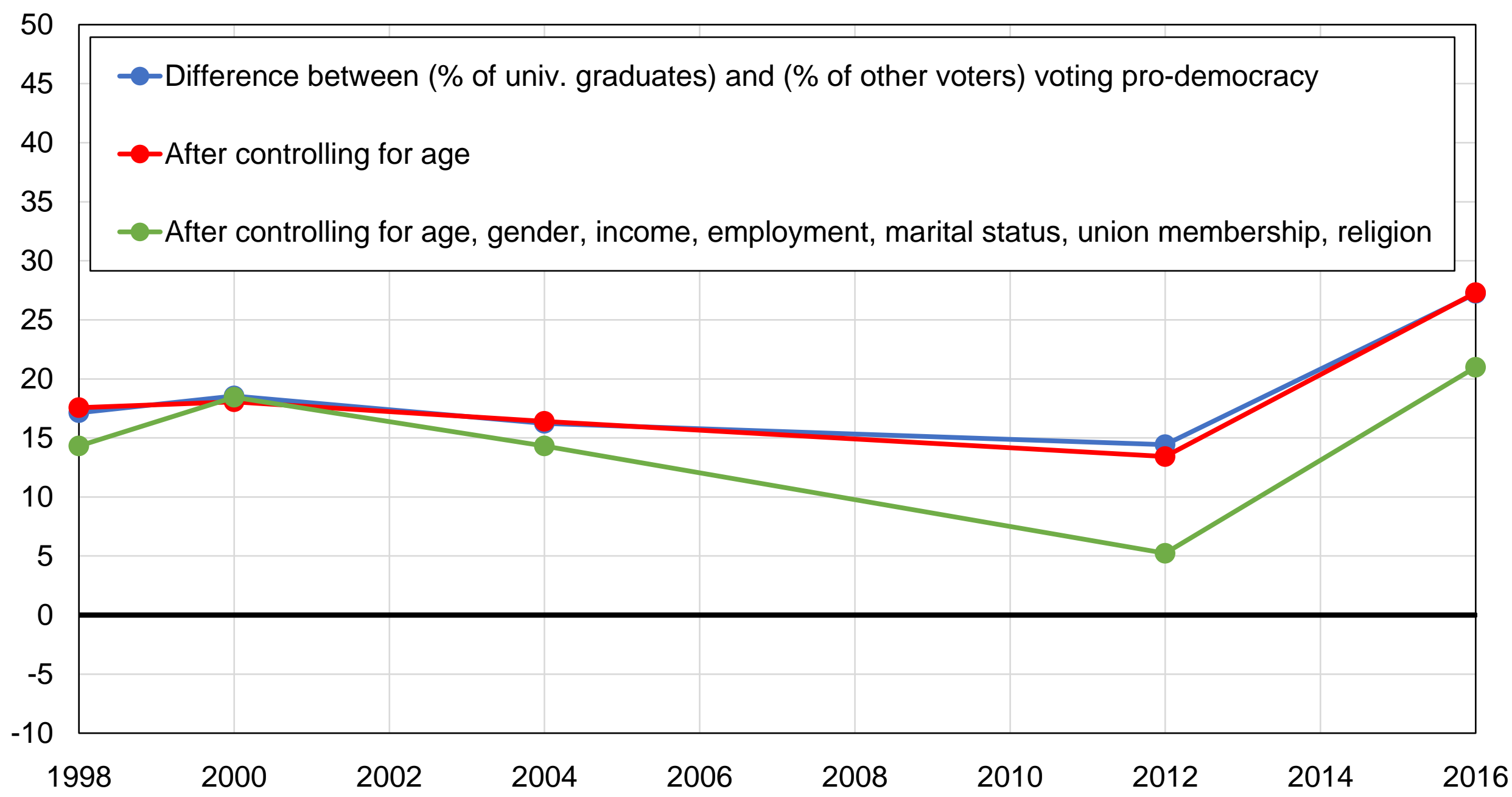

Source: authors' computations using Hong Kong political attitudes surveys.

Note: the figure shows the difference between the share of university graduates and the share of other voters voting for the pro-democracy camp, before and after controlling for other variables. 


\section{Figure C24 - Vote for pro-democracy among top 10\% earners}

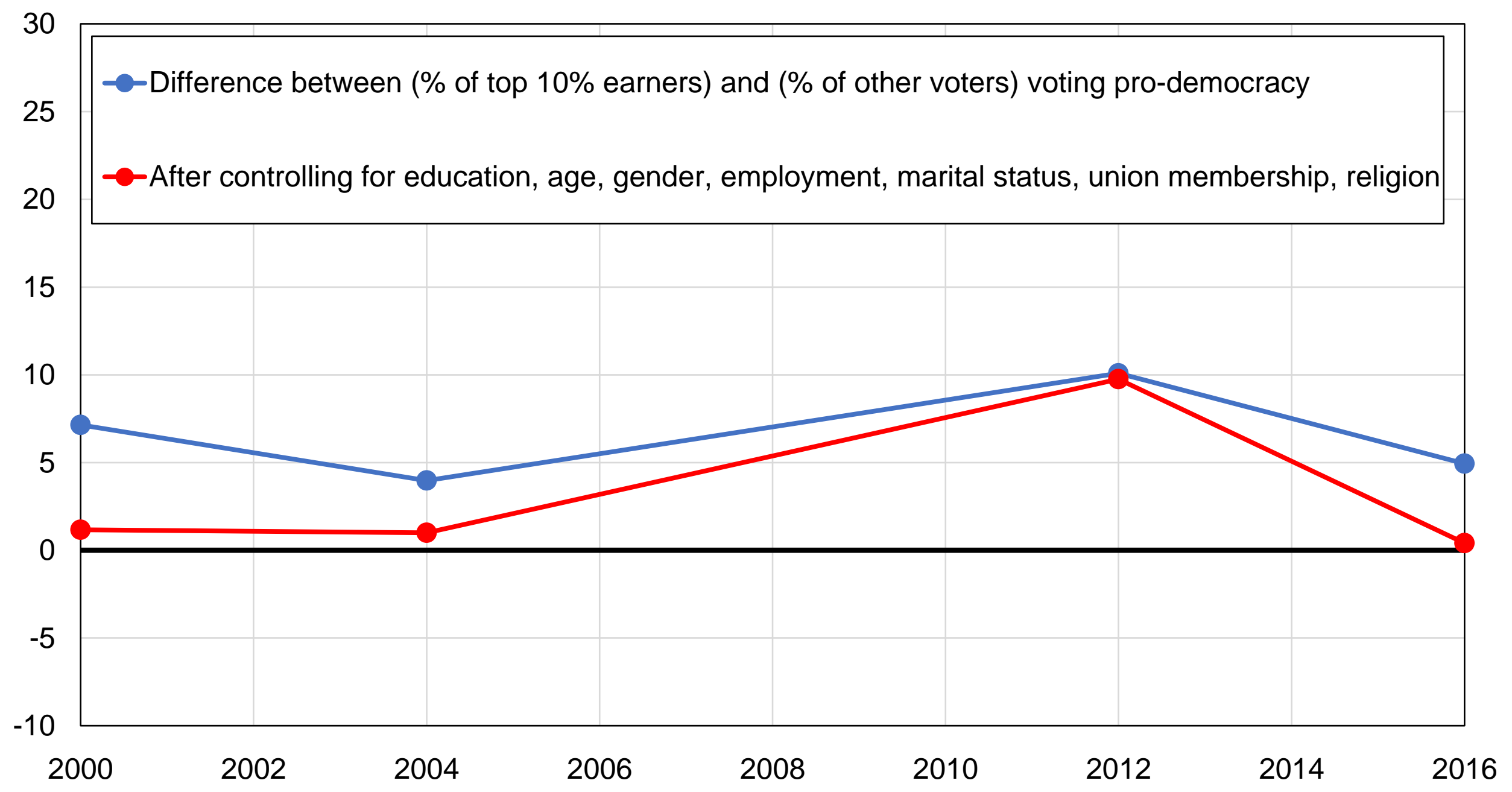

Source: authors' computations using Hong Kong political attitudes surveys.

Note: the figure shows the difference between the share of top 10\% earners and the share of other voters voting for the pro-democracy camp, before and after controlling for other variables. 


\section{Figure C25 - Vote for pro-democracy among union members}

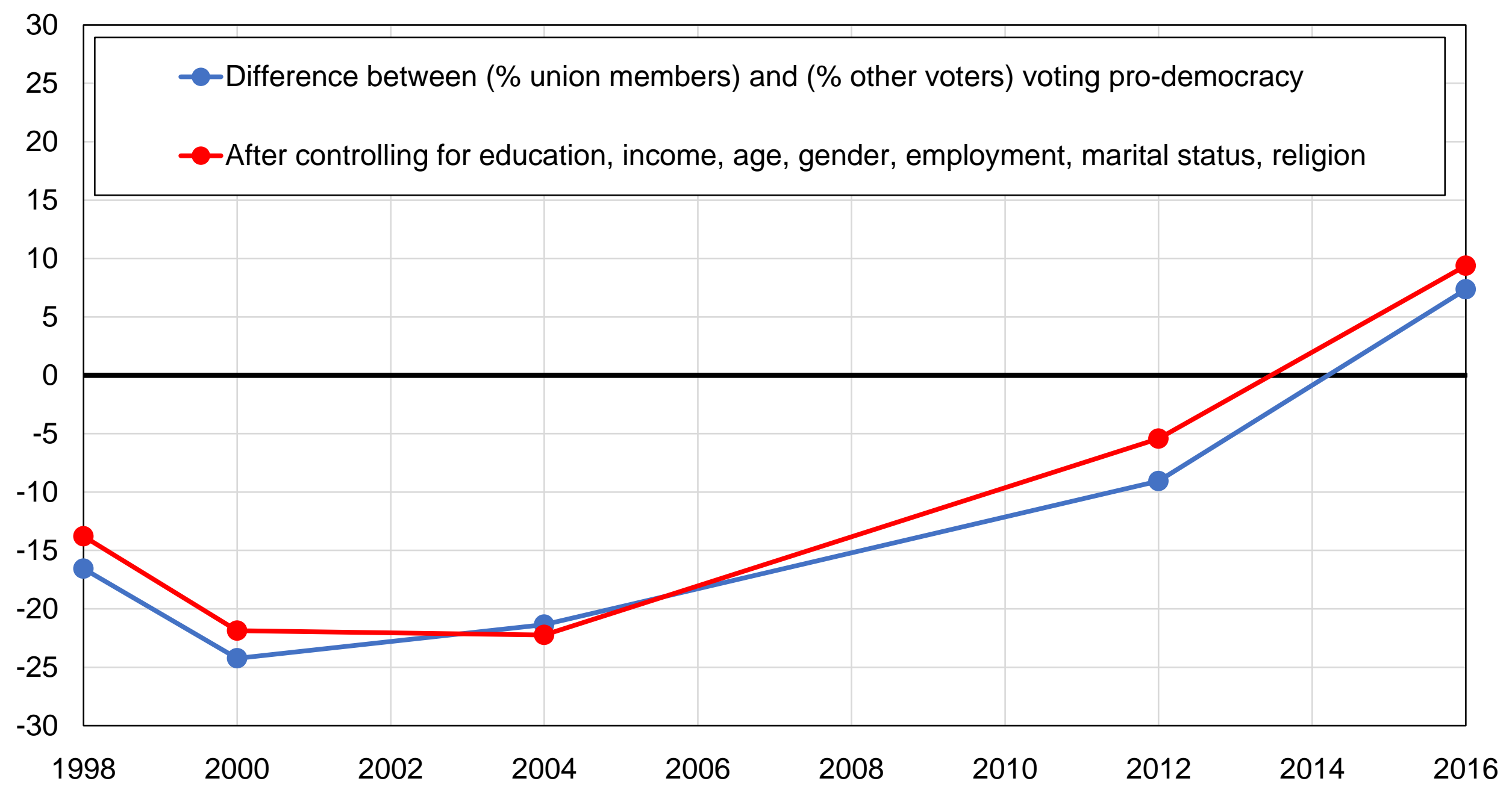

Source: authors' computations using Hong Kong political attitudes surveys.

Note: the figure shows the difference between the share of union members and the share of other voters voting for the pro-democracy camp, before and after controlling for other variables. 


\section{Figure C26 - Vote for pro-democracy among women}

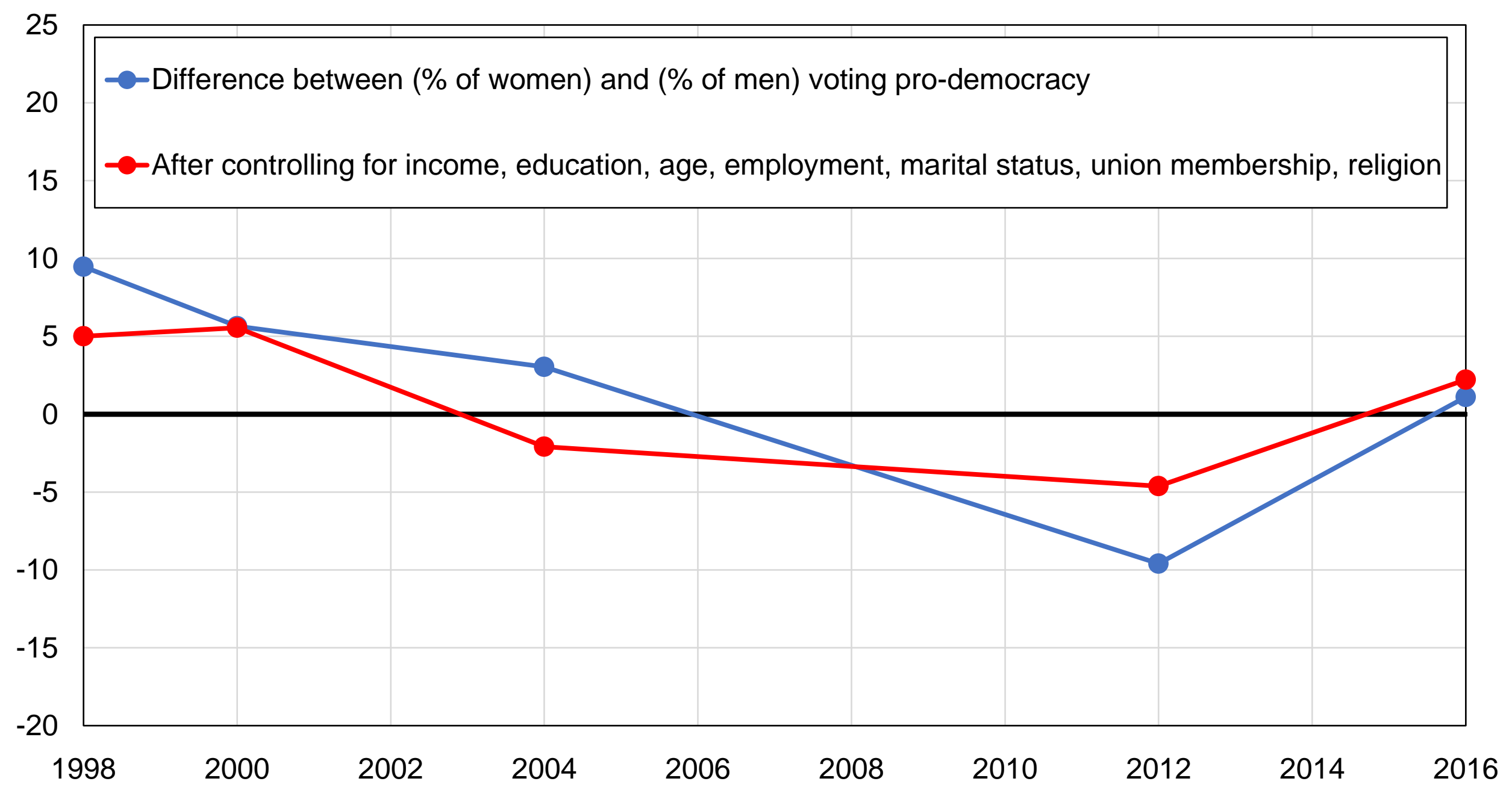

Source: authors' computations using Hong Kong political attitudes surveys.

Note: the figure shows the difference between the share of women and the share of men voting for the prodemocracy camp, before and after controlling for other variables. 


\section{Figure C27 - Vote for pro-democracy among non-single voters}

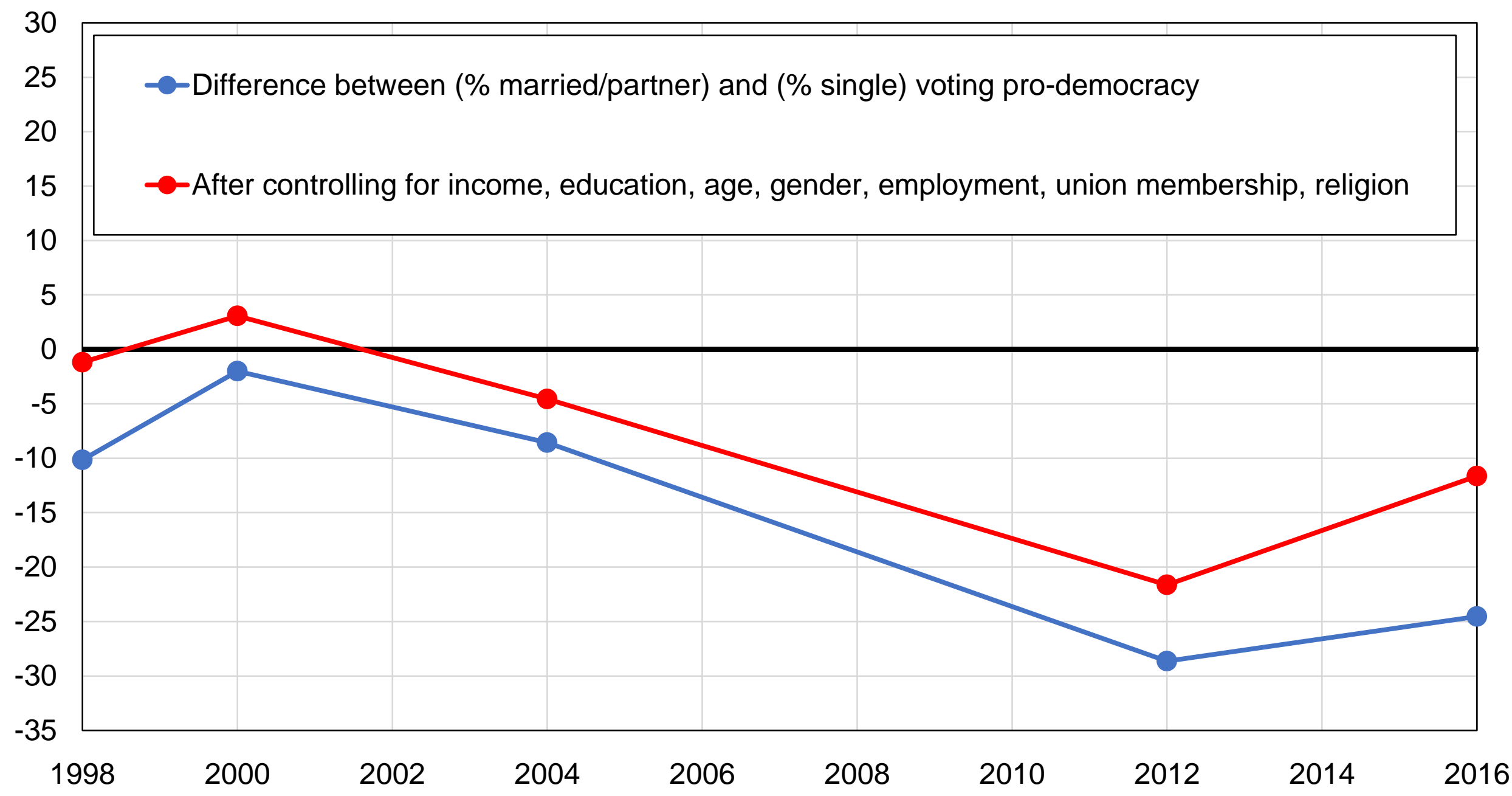

Source: authors' computations using Hong Kong political attitudes surveys.

Note: the figure shows the difference between the share of married voters or voters with partners and the share of other voters voting for the pro-democracy camp, before and after controlling for other variables. 


\section{Figure C28 - Vote for pro-democracy among Christians}

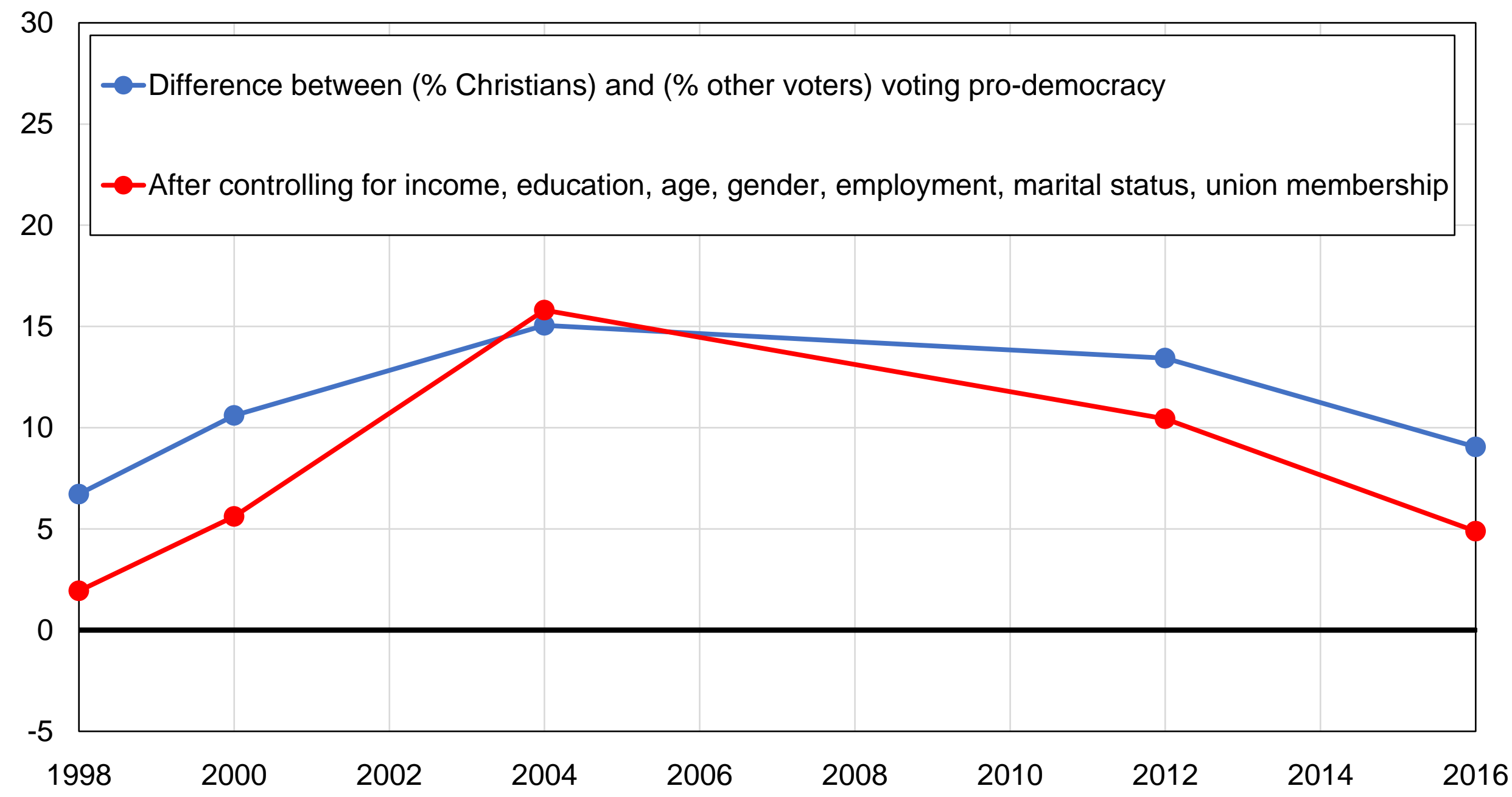

Source: authors' computations using Hong Kong political attitudes surveys.

Note: the figure shows the difference between the share of Christian voters and the share of other voters voting for the pro-democracy camp, before and after controlling for other variables. 
Figure C29 - Vote for pro-democracy by place of birth and age

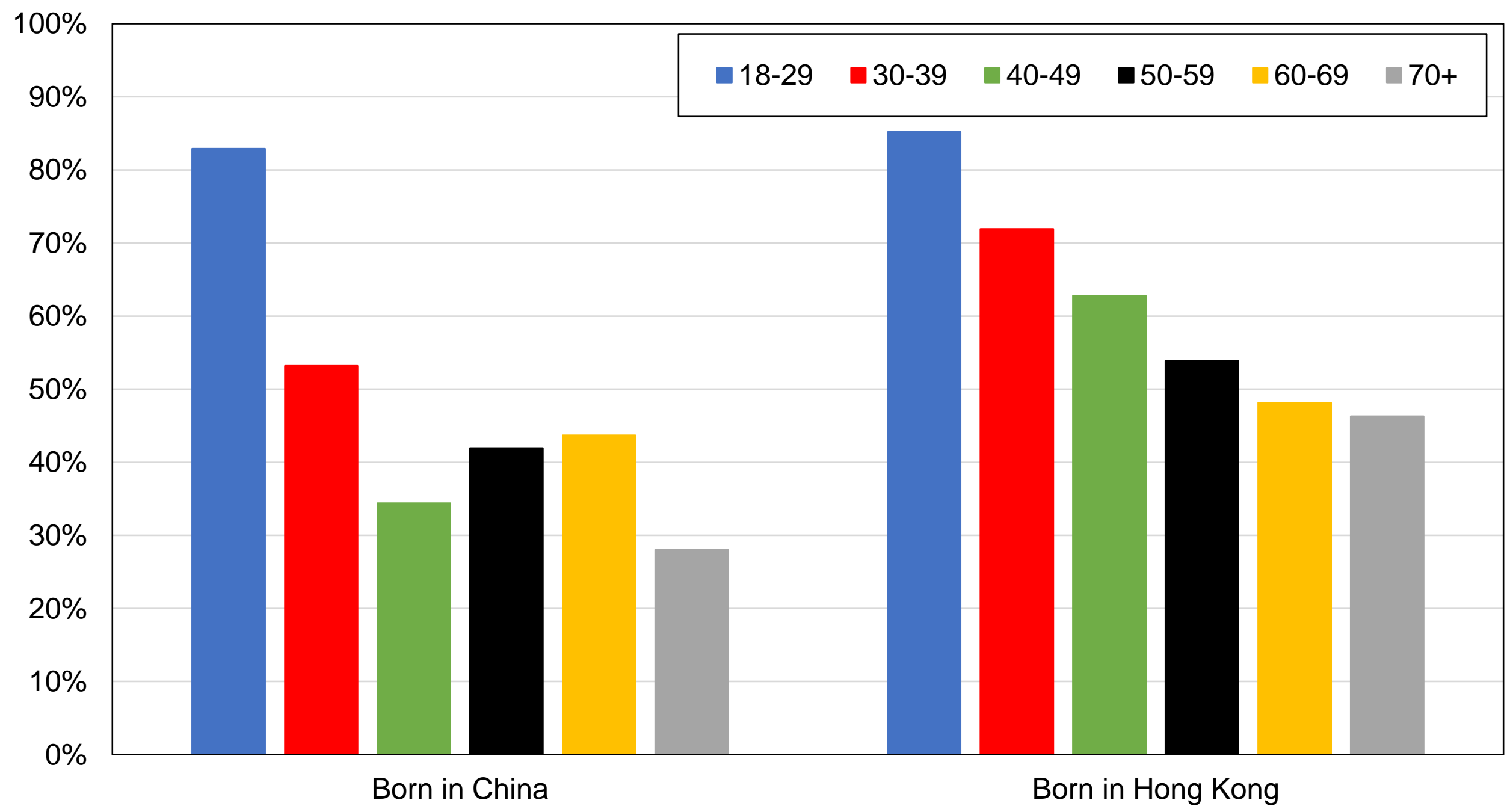

Source: authors' computations using Hong Kong political attitudes surveys.

Note: the figure shows the average share of votes received by the pro-democracy camp by age and place of birth in the 2012 and 2016 elections. 
Figure C30 - Vote for pro-democracy by place of birth and education

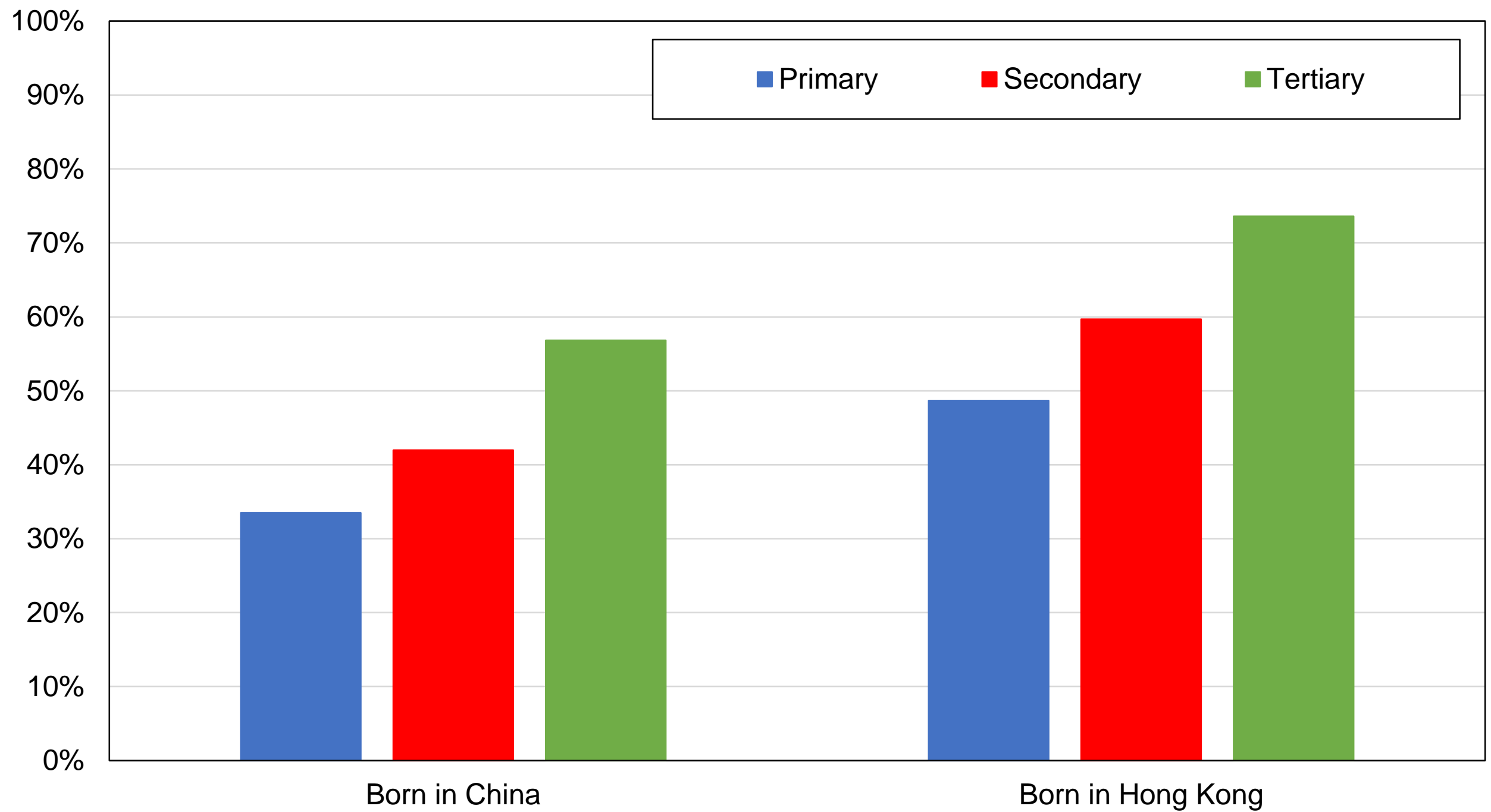

Source: authors' computations using Hong Kong political attitudes surveys.

Note: the figure shows the share of votes received by the pro-democracy camp by education and place of birth in the 2012 and 2016 elections. 


\begin{tabular}{|clcc|}
\hline \multicolumn{5}{|c|}{ Table C1 - Survey data sources } \\
\hline Year & \multicolumn{1}{|c|}{ Survey } & Source & Sample size \\
\hline 1998 & Comparative Study of Electoral Systems & CSES & 1000 \\
2000 & Comparative Study of Electoral Systems & CSES & 674 \\
2004 & Comparative Study of Electoral Systems & CSES & 582 \\
2012 & Comparative Study of Electoral Systems & CSES & 1044 \\
2016 & Comparative Study of Electoral Systems & CSES & 1020 \\
\hline Source: authors' elaboration. & & \\
Note: the table shows the surveys used in the paper, the source from which these surveys can be obtained, \\
and the sample size of each survey. CSES: Comparative Study of Electoral System. \\
\hline
\end{tabular}




\begin{tabular}{|c|c|c|c|c|c|}
\hline \multicolumn{6}{|c|}{ Table C2 - Complete descriptive statistics by year } \\
\hline & 1998 & 2000 & 2004 & 2012 & 2016 \\
\hline Education: Primary & $36 \%$ & $32 \%$ & $31 \%$ & $32 \%$ & $24 \%$ \\
\hline Education: Secondary & $51 \%$ & $59 \%$ & $57 \%$ & $44 \%$ & $44 \%$ \\
\hline Education: Tertiary & $13 \%$ & $10 \%$ & $12 \%$ & $24 \%$ & $32 \%$ \\
\hline Age: $20-40$ & $41 \%$ & $43 \%$ & $26 \%$ & $33 \%$ & $26 \%$ \\
\hline Age: $40-60$ & $42 \%$ & $44 \%$ & $54 \%$ & $47 \%$ & $50 \%$ \\
\hline Age: $60+$ & $18 \%$ & $14 \%$ & $20 \%$ & $20 \%$ & $24 \%$ \\
\hline Gender : Man & $50 \%$ & $47 \%$ & $57 \%$ & $45 \%$ & $49 \%$ \\
\hline Employment status: Employed & $62 \%$ & $60 \%$ & $58 \%$ & $51 \%$ & $52 \%$ \\
\hline Employment status: Unemployed & $4 \%$ & $4 \%$ & $7 \%$ & $3 \%$ & $2 \%$ \\
\hline Employment status: Inactive & $34 \%$ & $36 \%$ & $35 \%$ & $46 \%$ & $46 \%$ \\
\hline Marital status : Married / With partner & $73 \%$ & $69 \%$ & $73 \%$ & $71 \%$ & $68 \%$ \\
\hline Religion: No religion & $77 \%$ & $76 \%$ & $72 \%$ & $69 \%$ & $70 \%$ \\
\hline Religion: Christian & $13 \%$ & $13 \%$ & $13 \%$ & $20 \%$ & $20 \%$ \\
\hline Religion: Buddhist / Taoist / Other & $10 \%$ & $11 \%$ & $15 \%$ & $11 \%$ & $10 \%$ \\
\hline Union membership : Yes & $11 \%$ & $8 \%$ & $9 \%$ & $6 \%$ & $7 \%$ \\
\hline Place of birth: China & & & & $25 \%$ & $28 \%$ \\
\hline Place of birth: Hong Kong & & & & $72 \%$ & $71 \%$ \\
\hline Place of birth: Other & & & & $3 \%$ & $2 \%$ \\
\hline
\end{tabular}


Table C3 - Determinants of the vote for the pro-democracy camp, 1998-2016

\begin{tabular}{|c|c|c|c|c|c|c|}
\hline & $\begin{array}{c}(1) \\
1998\end{array}$ & $\begin{array}{c}(2) \\
2000\end{array}$ & $\begin{array}{c}(3) \\
2004\end{array}$ & $\begin{array}{c}(4) \\
2012\end{array}$ & $\begin{array}{c}(5) \\
2016\end{array}$ & $\begin{array}{c}(6) \\
1998-2016\end{array}$ \\
\hline Age: $18-29$ & (baseline) & (baseline) & (baseline) & (baseline) & (baseline) & (baseline) \\
\hline Age: $30-39$ & $0.090^{*}$ & 0.066 & -0.012 & -0.041 & 0.007 & $0.055^{*}$ \\
\hline & $(0.051)$ & $(0.076)$ & $(0.078)$ & $(0.058)$ & $(0.071)$ & $(0.029)$ \\
\hline Age: $40-49$ & 0.048 & 0.027 & 0.057 & -0.097 & -0.050 & 0.014 \\
\hline & $(0.053)$ & $(0.077)$ & $(0.065)$ & $(0.061)$ & $(0.088)$ & $(0.029)$ \\
\hline Age: $50-59$ & $\begin{array}{c}0.037 \\
(0.060)\end{array}$ & $\begin{array}{c}0.050 \\
(0.086)\end{array}$ & $\begin{array}{c}0.030 \\
(0.069)\end{array}$ & $\begin{array}{c}-0.185^{\star * *} \\
(0.061)\end{array}$ & $\begin{array}{l}-0.085 \\
(0.087)\end{array}$ & $\begin{array}{l}-0.040 \\
(0.031)\end{array}$ \\
\hline Age: $60-69$ & $\begin{array}{c}-0.167^{* *} \\
(0.070)\end{array}$ & $\begin{array}{c}0.105 \\
(0.108)\end{array}$ & $\begin{array}{l}-0.172^{*} \\
(0.094)\end{array}$ & $\begin{array}{l}-0.033 \\
(0.063)\end{array}$ & $\begin{array}{l}-0.135 \\
(0.088)\end{array}$ & $\begin{array}{c}-0.126^{\star \star *} \\
(0.036)\end{array}$ \\
\hline Age: $70+$ & $\begin{array}{c}-0.242^{\star \star *} \\
(0.078)\end{array}$ & $\begin{array}{l}-0.056 \\
(0.131)\end{array}$ & $\begin{array}{l}-0.066 \\
(0.091)\end{array}$ & $\begin{array}{c}-0.242^{* * *} \\
(0.068)\end{array}$ & $\begin{array}{l}-0.148 \\
(0.111)\end{array}$ & $\begin{array}{c}-0.190^{* \star *} \\
(0.042)\end{array}$ \\
\hline Education: Primary & $\begin{array}{c}\text { (baseline) } \\
(.)\end{array}$ & $\begin{array}{c}\text { (baseline) } \\
(.)\end{array}$ & $\begin{array}{c}\text { (baseline) } \\
(.)\end{array}$ & $\begin{array}{c}\text { (baseline) } \\
(.)\end{array}$ & $\begin{array}{c}\text { (baseline) } \\
(.)\end{array}$ & $\begin{array}{c}\text { (baseline) } \\
(.)\end{array}$ \\
\hline Education: Secondary & $\begin{array}{l}0.062^{*} \\
(0.035)\end{array}$ & $\begin{array}{c}0.048 \\
(0.052)\end{array}$ & $\begin{array}{l}-0.065 \\
(0.044)\end{array}$ & $\begin{array}{l}0.095^{* *} \\
(0.041)\end{array}$ & $\begin{array}{l}-0.017 \\
(0.060)\end{array}$ & $\begin{array}{l}-0.002 \\
(0.021)\end{array}$ \\
\hline Education: Tertiary & $\begin{array}{c}0.158^{* * *} \\
(0.049)\end{array}$ & $\begin{array}{l}0.182^{* *} \\
(0.085)\end{array}$ & $\begin{array}{c}0.082 \\
(0.065)\end{array}$ & $\begin{array}{c}0.005 \\
(0.049)\end{array}$ & $\begin{array}{l}0.134^{* *} \\
(0.067)\end{array}$ & $\begin{array}{l}0.055^{\star *} \\
(0.026)\end{array}$ \\
\hline Income quintile: 1 & $\begin{array}{c}\text { (baseline) } \\
(.)\end{array}$ & $\begin{array}{c}\text { (baseline) } \\
(.)\end{array}$ & $\begin{array}{c}\text { (baseline) } \\
(.)\end{array}$ & $\begin{array}{c}\text { (baseline) } \\
\text { (.) }\end{array}$ & $\begin{array}{c}\text { (baseline) } \\
(.)\end{array}$ & $\begin{array}{c}\text { (baseline) } \\
(.)\end{array}$ \\
\hline Income quintile: 2 & $\begin{array}{c}0.032 \\
(0.044)\end{array}$ & $\begin{array}{c}0.011 \\
(0.068)\end{array}$ & $\begin{array}{c}0.016 \\
(0.065)\end{array}$ & $\begin{array}{c}0.016 \\
(0.048)\end{array}$ & $\begin{array}{l}-0.046 \\
(0.080)\end{array}$ & $\begin{array}{c}0.003 \\
(0.028)\end{array}$ \\
\hline Income quintile: 3 & $\begin{array}{c}0.006 \\
(0.044)\end{array}$ & $\begin{array}{c}0.066 \\
(0.068)\end{array}$ & $\begin{array}{c}0.010 \\
(0.060)\end{array}$ & $\begin{array}{c}0.009 \\
(0.057)\end{array}$ & $\begin{array}{l}-0.026 \\
(0.081)\end{array}$ & $\begin{array}{c}0.008 \\
(0.028)\end{array}$ \\
\hline Income quintile: 4 & $\begin{array}{c}0.030 \\
(0.045)\end{array}$ & $\begin{array}{c}0.002 \\
(0.070)\end{array}$ & $\begin{array}{c}0.032 \\
(0.060)\end{array}$ & $\begin{array}{c}0.076 \\
(0.056)\end{array}$ & $\begin{array}{l}-0.005 \\
(0.084)\end{array}$ & $\begin{array}{c}0.019 \\
(0.028)\end{array}$ \\
\hline Income quintile: 5 & $\begin{array}{c}0.046 \\
(0.049)\end{array}$ & $\begin{array}{c}0.033 \\
(0.077)\end{array}$ & $\begin{array}{c}0.032 \\
(0.067)\end{array}$ & $\begin{array}{l}0.151^{* *} \\
(0.063)\end{array}$ & $\begin{array}{c}0.007 \\
(0.088)\end{array}$ & $\begin{array}{c}0.039 \\
(0.030)\end{array}$ \\
\hline
\end{tabular}




\begin{tabular}{|c|c|c|c|c|c|c|}
\hline Gender: Man & -0.049 & -0.033 & 0.021 & 0.050 & -0.031 & -0.009 \\
\hline & $(0.030)$ & $(0.043)$ & $(0.040)$ & $(0.032)$ & $(0.039)$ & $(0.017)$ \\
\hline \multirow[t]{2}{*}{ Employment status: Inactive } & $0.067^{* *}$ & -0.077 & 0.035 & -0.030 & $-0.101^{* *}$ & -0.018 \\
\hline & $(0.033)$ & $(0.053)$ & $(0.046)$ & $(0.040)$ & $(0.049)$ & $(0.020)$ \\
\hline Marital status: Married / Partner & $\begin{array}{l}-0.062 \\
(0.042)\end{array}$ & $\begin{array}{l}-0.051 \\
(0.056)\end{array}$ & $\begin{array}{l}-0.094^{*} \\
(0.049)\end{array}$ & $\begin{array}{l}-0.223^{* * *} \\
(0.041)\end{array}$ & $\begin{array}{l}-0.228^{* * *} \\
(0.065)\end{array}$ & $\begin{array}{c}-0.130^{* * *} \\
(0.022)\end{array}$ \\
\hline Religion: No religion & $\begin{array}{c}\text { (baseline) } \\
(.)\end{array}$ & $\begin{array}{c}\text { (baseline) } \\
(.)\end{array}$ & $\begin{array}{c}\text { (baseline) } \\
(.)\end{array}$ & $\begin{array}{c}\text { (baseline) } \\
(.)\end{array}$ & $\begin{array}{c}\text { (baseline) } \\
(.)\end{array}$ & $\begin{array}{c}\text { (baseline) } \\
(.)\end{array}$ \\
\hline Religion: Christian & $\begin{array}{l}-0.004 \\
(0.042)\end{array}$ & $\begin{array}{c}0.179^{\star * \star} \\
(0.056)\end{array}$ & $\begin{array}{c}0.158^{\star \star \star} \\
(0.045)\end{array}$ & $\begin{array}{c}0.114^{\star \star *} \\
(0.043)\end{array}$ & $\begin{array}{c}0.058 \\
(0.043)\end{array}$ & $\begin{array}{c}0.083^{* * *} \\
(0.021)\end{array}$ \\
\hline Religion: Buddhist / Taoist / Other & $\begin{array}{l}-0.073 \\
(0.050)\end{array}$ & $\begin{array}{l}-0.020 \\
(0.066)\end{array}$ & $\begin{array}{c}0.076 \\
(0.054)\end{array}$ & $\begin{array}{l}-0.024 \\
(0.050)\end{array}$ & $\begin{array}{l}-0.060 \\
(0.077)\end{array}$ & $\begin{array}{l}-0.013 \\
(0.027)\end{array}$ \\
\hline Union membership: Yes & $\begin{array}{l}-0.124^{* * *} \\
(0.042)\end{array}$ & $\begin{array}{c}-0.213^{* * *} \\
(0.069)\end{array}$ & $\begin{array}{l}-0.207^{* * *} \\
(0.059)\end{array}$ & $\begin{array}{l}-0.142^{* *} \\
(0.066)\end{array}$ & $\begin{array}{c}0.061 \\
(0.077)\end{array}$ & $\begin{array}{c}-0.119^{* * *} \\
(0.027)\end{array}$ \\
\hline Constant & $\begin{array}{c}0.683^{\star * *} \\
(0.058)\end{array}$ & $\begin{array}{c}0.594^{* * *} \\
(0.092)\end{array}$ & $\begin{array}{c}0.671^{* * *} \\
(0.079)\end{array}$ & $\begin{array}{c}0.709^{* * *} \\
(0.065)\end{array}$ & $\begin{array}{c}0.837^{\star * *} \\
(0.111)\end{array}$ & $\begin{array}{c}0.730^{* * *} \\
(0.035)\end{array}$ \\
\hline \multicolumn{2}{|l|}{$\begin{array}{l}\text { R-squared } \\
{ }^{*} p<0.10,{ }^{* *} p<0.05,{ }^{* * *} p<0.01\end{array}$} & 0.07 & 0.07 & 0.13 & 0.16 & 0.07 \\
\hline \multicolumn{7}{|c|}{$\begin{array}{l}\text { Source: authors' computations using Hong Kong political attitudes surveys. } \\
\text { Note: the table shows the results of a multivariate regression assessing the determinants of support for the pro-democracy camp by } \\
\text { year, and over the entire period studied. }\end{array}$} \\
\hline
\end{tabular}


Table C4 - Attitudes towards identity, immigration, and integration with China by age group, 2015

\begin{tabular}{|lccccc|}
\hline & $\mathbf{1 8 - 2 5}$ & $\mathbf{2 6 - 3 5}$ & $\mathbf{3 6 - 4 5}$ & $\mathbf{4 6 - 5 5}$ & $\mathbf{5 6 +}$ \\
\hline Closer integration with Mainland will not benefit Hong Kong & $72 \%$ & $63 \%$ & $54 \%$ & $41 \%$ & $43 \%$ \\
Do you think yourself as: Hong Konger & $76 \%$ & $70 \%$ & $61 \%$ & $49 \%$ & $45 \%$ \\
Hong Kong does not have a democratic political system & $69 \%$ & $63 \%$ & $62 \%$ & $57 \%$ & $75 \%$ \\
Too many immigrants coming from Mainland China & $81 \%$ & $79 \%$ & $75 \%$ & $71 \%$ & $34 \%$ \\
Among top 3 problems: Income inequality & $41 \%$ & $38 \%$ & $35 \%$ & $31 \%$ \\
\hline
\end{tabular}

Source: authors' computations based on the Hong Kong Election Study 2015.

Note: the table shows the share of individuals (1) disagreeing or strongly disagreeing that closer integration with Mainland China will benefit Hong Kong (2) thinking themselves as Hong Konger rather than Chinese, Chinese Hong Konger, Hong Kong Chinese, or Other (3) disagreeing or strongly disagreeing that Hong Kong has a democratic political system (4) agreeing or strongly agreeing that Hong Kong has too many immigrants coming from Mainland China (5) declaring income inequality as one of the three most important problems facing Hong Kong at the present time. 
Table C5 - Structure of the Hong Kong population by place of birth, 2016

\begin{tabular}{|l|cc|}
\hline & Hong Kong & Mainland China \\
\hline Overall population share & $71 \%$ & $28 \%$ \\
\hline Education & $15 \%$ & $44 \%$ \\
Primary & $46 \%$ & $39 \%$ \\
Secondary & $39 \%$ & $17 \%$ \\
Tertiary & & \\
Income quintile & $15 \%$ & $29 \%$ \\
Quintile 1 & $17 \%$ & $28 \%$ \\
Quintile 2 & $22 \%$ & $17 \%$ \\
Quintile 3 & $24 \%$ & $10 \%$ \\
Quintile 4 & $21 \%$ & $16 \%$ \\
Quintile 5 & & \\
Age & $32 \%$ & $12 \%$ \\
$20-40$ & $54 \%$ & $42 \%$ \\
$40-60$ & $14 \%$ & $46 \%$ \\
$60+$ & &
\end{tabular}

Source: authors' computations using Hong Kong political attitudes surveys.

Note: the table show the composition of the Hong Kong population decomposed by location

of birth in 2016. The share of the electorate born in Hong Kong was about $71 \% ; 15 \%$ of them were primary educated, as compared to $44 \%$ of individuals born in China. 
Figure C3b - Vote for pro-democracy by decade of birth

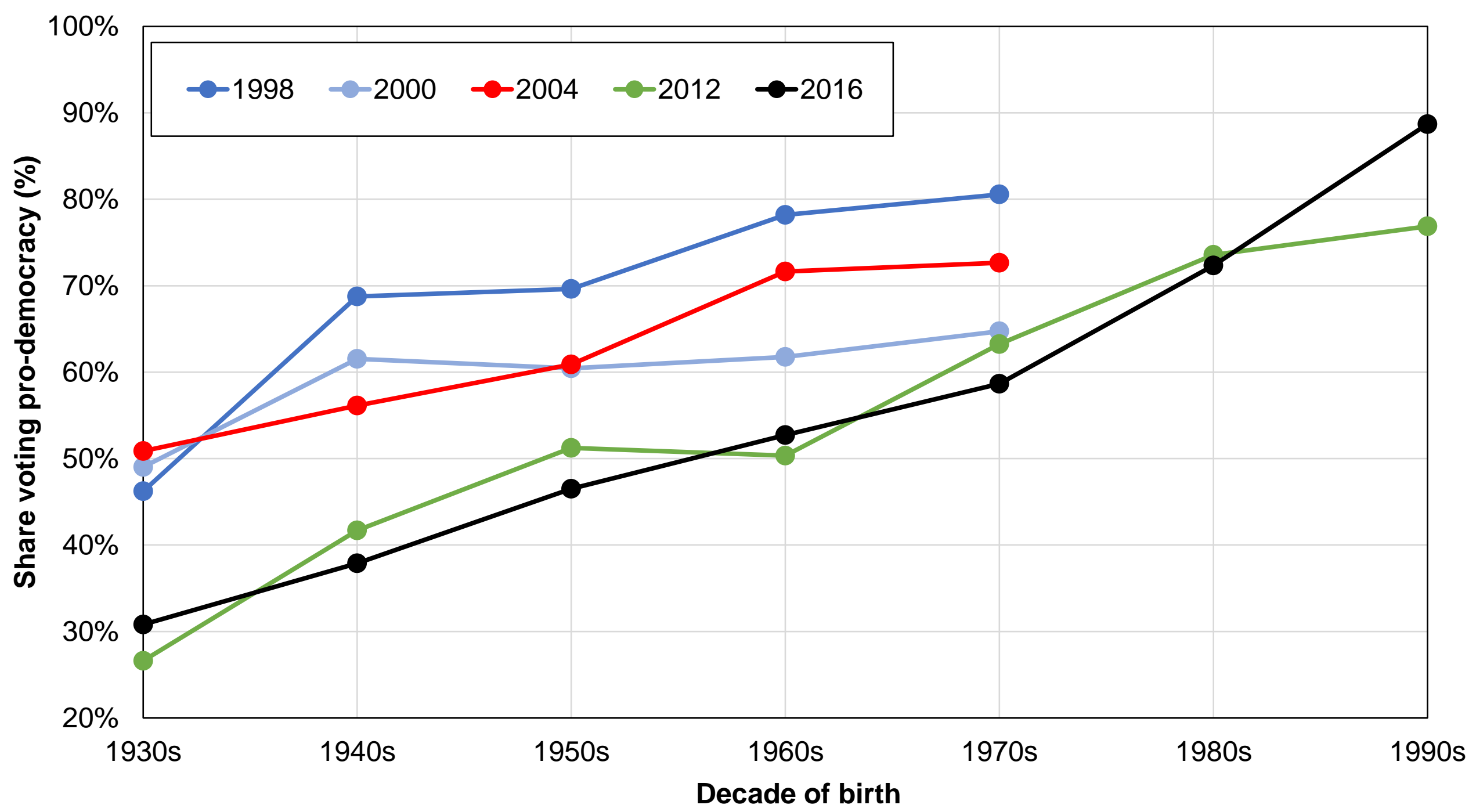

Source: authors' computations using Hong Kong political attitudes surveys.

Note: the figure shows the share of votes received by the pro-democracy camp by decade of birth. 